Prepared in cooperation with the Minnesota Board of Water and Soil Resources

\title{
Water-Quality and Biological Characteristics and Responses to Agricultural Land Retirement in Three Streams of the Minnesota River Basin, Water Years 2006-08
}

Scientificinvestigations Report 2009-5215
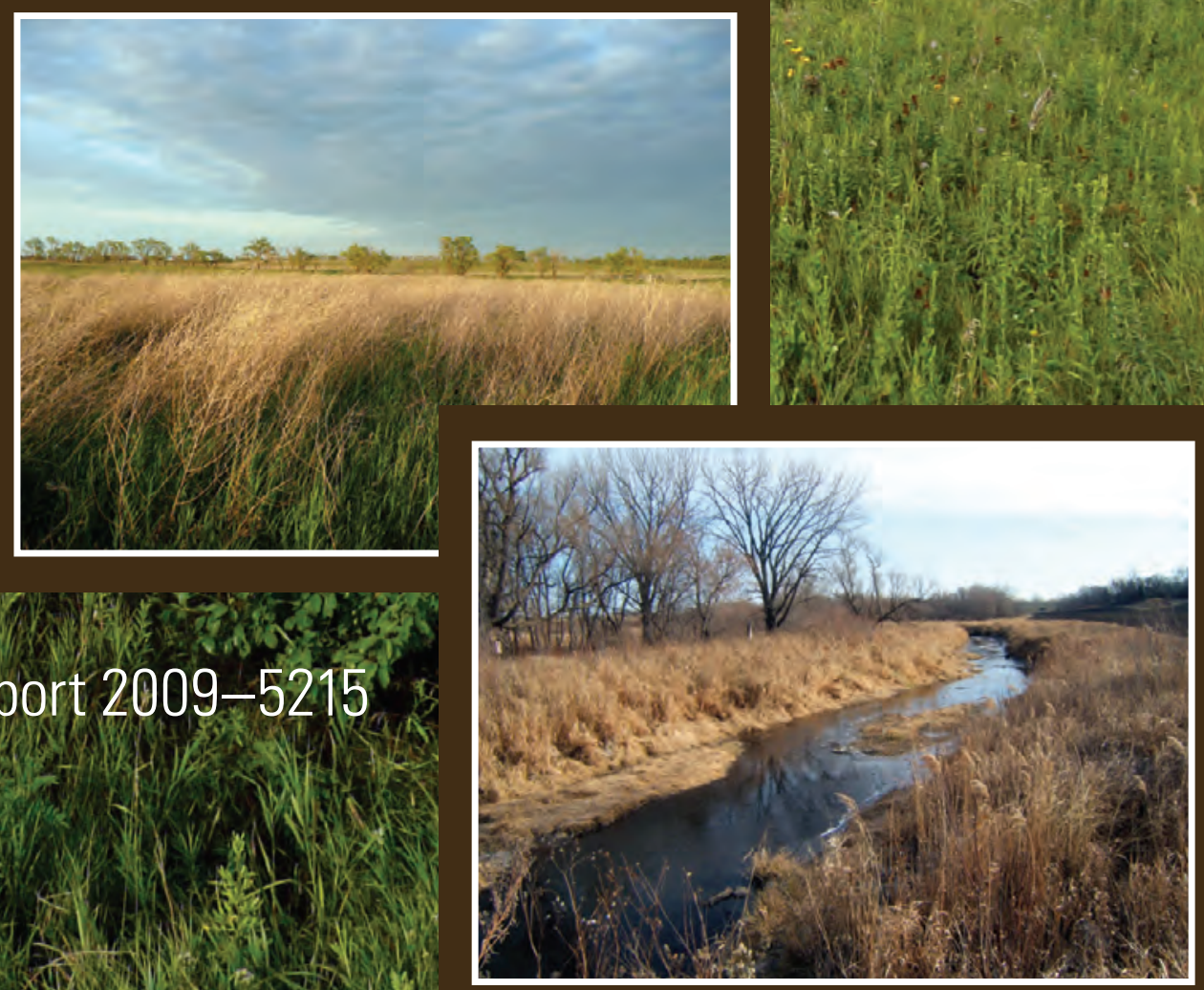



\section{Water-Quality and Biological Characteristics and Responses to Agricultural Land Retirement in Three Streams of the Minnesota River Basin, Water Years 2006-08}

By Victoria G. Christensen, Kathy E. Lee, Christopher A. Sanocki, Eric H. Mohring, and

Richard L. Kiesling

Prepared in cooperation with the Minnesota Board of Water and Soil Resources

Scientific Investigations Report 2009-5215 


\section{U.S. Department of the Interior \\ KEN SALAZAR, Secretary \\ U.S. Geological Survey Marcia K. McNutt, Director}

\section{U.S. Geological Survey, Reston, Virginia: 2009}

This and other USGS information products are available at http://store.usgs.gov/

U.S. Geological Survey

Box 25286, Denver Federal Center

Denver, C0 80225

To learn about the USGS and its information products visit http://www.usgs.gov/

1-888-ASK-USGS

Any use of trade, product, or firm names is for descriptive purposes only and does not imply endorsement by the U.S. Government.

Although this report is in the public domain, permission must be secured from the individual copyright owners to reproduce any copyrighted materials contained within this report.

\section{Suggested citation:}

Christensen, V.G., Lee, K.E., Sanocki, C.A., Mohring, E.H., and Kiesling, R.L., 2009, Water-quality and biological characteristics and responses to agricultural land retirement in three streams of the Minnesota River Basin, water years 2006-08: U.S. Geological Survey Scientific Investigations Report 2009-5215, 52 p., 3 app. 


\section{Acknowledgments}

The authors appreciate the assistance of Konrad Schmidt, Minnesota Department of Natural Resources, for providing fish identification and of Stephanie Klamm, Hawk Creek Watershed Project, for providing flow and nutrient data for Chetomba Creek and West Fork Beaver Creek. The authors also thank many USGS personnel and students for the onsite help, data collection, geographic information system (GIS) analysis, and record keeping. Partial support for this study was provided by the Minnesota Environment and Natural Resources Trust Fund as recommended by the Legislative-Citizen Commission on Minnesota Resources (LCCMR). The Trust Fund is a permanent fund constitutionally established by the citizens of Minnesota to assist in the protection, conservation, preservation, and enhancement of the State's air, water, land, fish, wildlife, and other natural resources. Currently (2008), 40 percent of net Minnesota State Lottery proceeds are dedicated to building the Trust Fund and ensuring future benefits for Minnesota's environment and natural resources. 


\section{Contents}

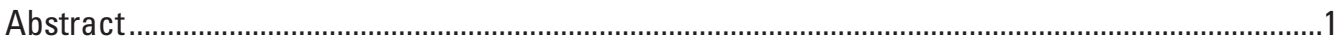

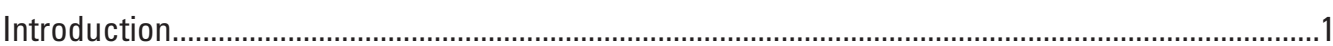

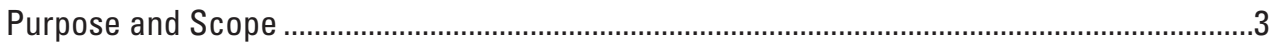

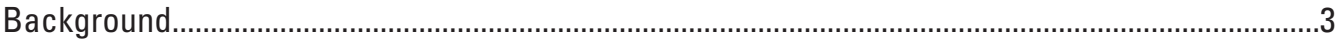

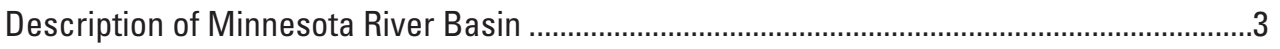

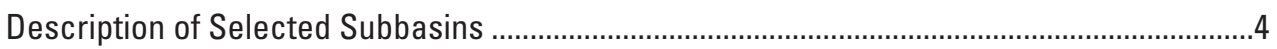

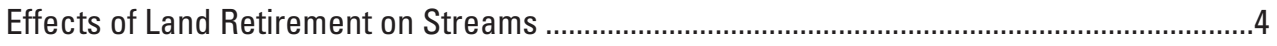

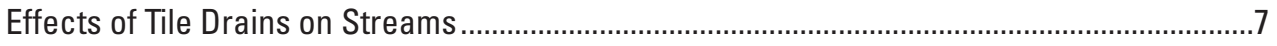

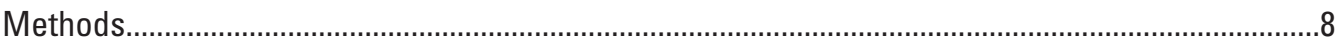

Site Selection and Determination of Retired Agricultural Land Distribution .............................8

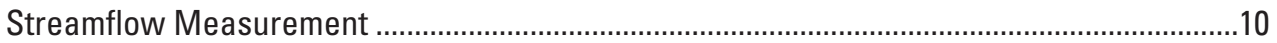

Real-Time Water-Quality Monitoring ...................................................................................

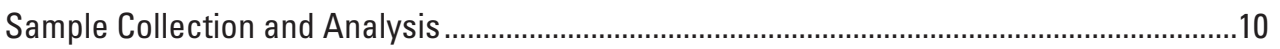

Water-Quality Sample Collection and Analysis ................................................................11

Physical Habitat Characterization ...................................................................................13

Collection and Analysis of Benthic Algal Samples ....................................................13

Collection and Analysis of Invertebrate Samples .......................................................15

Collection and Analysis of Fish.................................................................................15

Longitudinal Synoptic Survey of Biomass Accumulation ..............................................15

Water-Quality Characteristics of Three Streams in the Minnesota River Basin ............................17

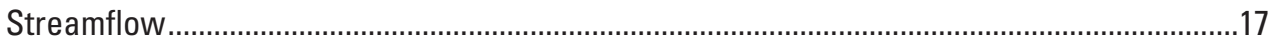

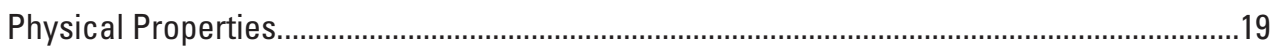

Nutrient, Suspended-Sediment, and Chlorophyll-a Concentrations.......................................20

Effects of Streamflow on Suspended-Sediment Concentrations ...........................................28

Biological Characteristics of Three Streams in the Minnesota River Basin ...................................30

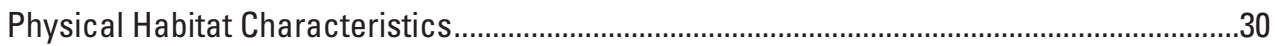

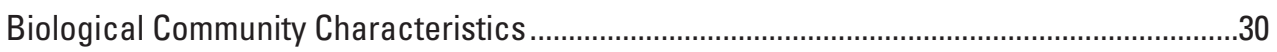

Benthic Algal Community Characteristics.....................................................................

Benthic Invertebrate Community Characteristics...........................................................37

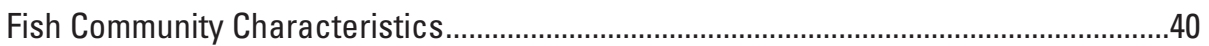

Water-Quality and Biological Responses to Agricultural Land Retirement....................................41

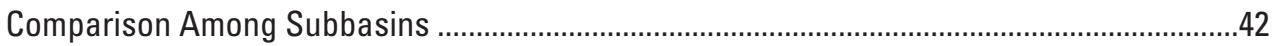

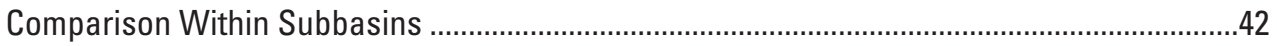

Implications

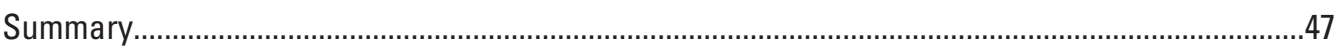

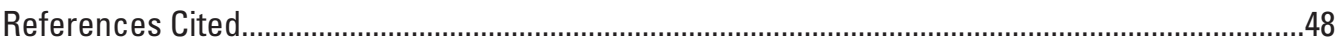

Appendix 1. Algal species composition, density, and biovolume for samples collected from Chetomba Creek, West Fork Beaver Creek, and South Branch Rush River, August 2006 and July 2007

Appendix 2. Invertebrate species composition and abundance for samples collected from Chetomba Creek, West Fork Beaver Creek, and South Branch Rush River, August 2006 and July 2007 
Appendix 3. Fish species composition, weight, and catch per unit effort for samples collected from Chetomba Creek, West Fork Beaver Creek, and

South Branch Rush River, August 2006 and 2007.

\section{Figures}

1. Maps showing location of the Minnesota River Basin, Chetomba Creek Basin, West Fork Beaver Creek Basin, and South Branch Rush River drainage subbasins and location of streamflow-gaging stations and water-quality sampling sites

2. Photograph of South Branch Rush River near Norseland, September 2005..................5

3. Schematic diagram showing surface flows for land in row crops and for agricultural land in a conservation reserve program

4. Aerial photograph showing retired agricultural land within a small portion of the 50-meter, 100-meter, 200-meter, and 300-meter influence zones of the Chetomba Creek Basin

5. Photographs of a micro nutrient-diffusing substrate periphytometer prior to deployment, and deployed in Chetomba Creek, August 2008.

6-21. Graphs Showing -

6. Mean daily streamflow for Chetomba Creek near Renville, West Fork Beaver Creek near Bechyn, and South Branch

Rush River near Norseland, water years 2006-08.

7. Continuous water-quality measurements of physical properties during growing season for Chetomba Creek near Renville for 2006, 2007, and 2008

8. Continuous water-quality measurements of physical properties during growing season for Chetomba Creek near Maynard for 2006, 2007, and 2008

9. Continuous water-quality measurements of physical properties during growing season for West Fork Beaver Creek near Bechyn for 2006 and 2007.

10. Continuous water-quality measurements of physical properties during growing season for South Branch Rush River near Bernadotte for 2007 and 2008.

11. Continuous water-quality measurements of physical properties during growing season for South Branch Rush River near Norseland for 2006, 2007, and 2008

12. Suspended-sediment concentrations compared to streamflow during storms at Chetomba Creek near Renville, West Fork Beaver Creek near Bechyn, South Branch Rush River near Bernadotte, and South Branch Rush River near Norseland, water years 2006-08.

13. Distribution of algal taxa at selected sampling sites in the Minnesota River Basin by cell biovolume and cell density, 
14. Percentage of total algal biovolume represented by the three most abundant taxa at selected sampling sites in the Minnesota River Basin, August 2006 and July 2007

15. Distribution of insect taxa richness among insect orders at selected sampling sites in the Minnesota River Basin, August 2006 and July 2007.

16. Distribution of invertebrate taxa abundance at selected sampling sites in the Minnesota River Basin, August 2006 and July 2007.

17. Mean nutrient concentrations of nitrite plus nitrate, total nitrogen, total phosphorus at selected stream sampling sites in order of increasing percentage of agricultural land retirement, Minnesota River Basin, water years 2006-08

18. Abundance-weighted tolerance scores for invertebrate taxa collected from Chetomba Creek near Renville, West Fork Beaver Creek near Bechyn, and South Branch Rush River near Norseland, August 2006 and July 2007.

19. Comparison of agricultural land retirement within

the 50-meter influence zone to index of biotic integrity scores, number of fish collected, and percentage of fish that were classified as tolerant at Chetomba Creek near Renville, South Branch Rush River near Norseland, and West Fork Beaver Creek near Bechyn, August 2006 and 2007

20. Comparison of upstream and downstream water-quality data at Chetomba Creek near Renville and Maynard and South Branch Rush River at County Road 8 near Bernadotte and at County Road 63 near Norseland, water years 2006-08.

21. Mean growth rates for Chetomba Creek periphytometer deployments, August 2008

\section{Tables}

1. Percentage of land use in the Chetomba Creek, West Fork Beaver Creek, and South Branch Rush River subbasins, 2001

2. Estimates of fertilizer application for selected counties in the Minnesota River Basin, 2002

3. Criteria considered for selection of sites for study of water-quality and biological responses to agricultural land retirement, Minnesota River Basin

4. Percentage of agricultural land retirement in selected subbasins of the Minnesota River Basin, 2007

5. Nutrient concentrations in environmental and associated replicate samples from three streams in the Minnesota River Basin, south-central Minnesota, water years 2006-08.

6. Description of individual metrics that compose the index 
of biotic integrity

7. Streamflow at selected sampling sites in the Minnesota River Basin, water years 1999-2008

8. Mean nutrient, suspended-sediment, and seston chlorophyll-a concentrations in water from selected sampling sites in the Minnesota River Basin, water years 2006-08

9. Mean annual nutrient concentrations in water from selected sampling sites in the Minnesota River Basin, water years 2006-08

10. Summary of physical habitat characteristics for streams at selected sampling sites in the Minnesota River Basin, August 2006 and July 2007

11. Summary of algal community characteristics at selected stream sampling sites in the Minnesota River Basin,

August 2006 and July 2007

12. Summary of invertebrate community characteristics at selected stream sampling sites in the Minnesota River Basin,

August 2006 and July 2007

13. Percentage of total taxa abundance consisting of the three most abundant taxa collected at selected stream sampling sites in the Minnesota River Basin, August 2006 and July 2007

14. Water-quality-evaluation ratings for abundance-weighted tolerance scores.

15. Summary of fish community characteristics at selected stream sampling sites in the Minnesota River Basin, August 2006 and 2007 


\section{Conversion Factors and Datum}

\begin{tabular}{|c|c|c|}
\hline Multiply & By & To obtain \\
\hline \multicolumn{3}{|c|}{ Length } \\
\hline centimeter $(\mathrm{cm})$ & 0.3937 & inch (in.) \\
\hline millimeter $(\mathrm{mm})$ & 0.03937 & inch (in.) \\
\hline meter $(\mathrm{m})$ & 3.281 & foot $(\mathrm{ft})$ \\
\hline micron $(\mu \mathrm{m})$ & 0.00003937 & inch (in.) \\
\hline kilometer $(\mathrm{km})$ & 0.6214 & mile (mi) \\
\hline \multicolumn{3}{|c|}{ Area } \\
\hline square kilometer $\left(\mathrm{km}^{2}\right)$ & 247.1 & acre \\
\hline square kilometer $\left(\mathrm{km}^{2}\right)$ & 0.3861 & square mile $\left(\mathrm{mi}^{2}\right)$ \\
\hline square meter $\left(\mathrm{m}^{2}\right)$ & 10.76 & square foot $\left(\mathrm{ft}^{2}\right)$ \\
\hline \multicolumn{3}{|c|}{ Volume } \\
\hline liter (L) & 33.82 & ounce, fluid (fl. oz) \\
\hline cubic centimeter & $1.0 \times 10^{12}$ & cubic micrometer \\
\hline cubic meter $\left(\mathrm{m}^{3}\right)$ & 35.31 & cubic foot $\left(\mathrm{ft}^{3}\right)$ \\
\hline \multicolumn{3}{|c|}{ Rate } \\
\hline centimeter per year $(\mathrm{cm} / \mathrm{yr})$ & 0.3937 & inch per year (in/yr) \\
\hline \multicolumn{3}{|c|}{ Flow rate } \\
\hline cubic meter per second $\left(\mathrm{m}^{3} / \mathrm{s}\right)$ & 35.31 & cubic foot per second $\left(\mathrm{ft}^{3} / \mathrm{s}\right)$ \\
\hline \multicolumn{3}{|c|}{ Mass } \\
\hline $\operatorname{gram}(\mathrm{g})$ & 0.03527 & ounce, avoirdupois (oz) \\
\hline \multicolumn{3}{|c|}{ Slope } \\
\hline meter per mile (m/mi) & 3.281 & foot per mile ( $\mathrm{ft} / \mathrm{mi})$ \\
\hline
\end{tabular}

Temperature in degrees Celsius $\left({ }^{\circ} \mathrm{C}\right)$ may be converted to degrees Fahrenheit $\left({ }^{\circ} \mathrm{F}\right)$ as follows:

$$
{ }^{\circ} \mathrm{F}=\left(1.8 x^{\circ} \mathrm{C}\right)+32 \text {. }
$$

Vertical coordinate information is referenced to the North American Vertical Datum of 1988 (NAVD 88).

Horizontal coordinate information is referenced to the North American Datum of 1983 (NAD 83).

Altitude, as used in this report, refers to distance above the vertical datum.

Concentrations of chemical constituents in water are given in milligrams per liter $(\mathrm{mg} / \mathrm{L})$ and micrograms per liter $(\mu \mathrm{g} / \mathrm{L})$.

Algal biovolumes for phytoplankton and periphyton are given in cubic micrometers per square centimeter of collection area $\left(\mu \mathrm{m}^{3} / \mathrm{cm}^{2}\right)$.

Algal cell densities for phytoplankton and periphyton are given in cells per square centimeter of collection area (cells/ $\mathrm{cm}^{2}$ ).

Chlorophyll-a density for periphyton is given in milligrams per square meter $\left(\mathrm{mg} / \mathrm{m}^{2}\right)$.

Water year is the 12-month period beginning October 1 and ending September 30 of the following year. The water year is designated by the year in which it ends. For example, water year 2006 begins on October 1, 2005, and ends September 30, 2006. 


\section{Abbreviations and Acronyms}

$\begin{array}{ll}\mu \mathrm{m} & \text { micron } \\ \mu \mathrm{M} & \text { micromolar } \\ \text { BWSR } & \text { Minnesota Board of Water and Soil Resources } \\ \text { CREP } & \text { Conservation Reserve Enhancement Program } \\ \text { CRP } & \text { Conservation Reserve Program } \\ \text { DC } & \text { direct current } \\ \text { EWI } & \text { equal-width increment } \\ \text { FSA } & \text { Farm Services Agency } \\ \text { GIS } & \text { geographic information system } \\ \text { IBI } & \text { index of biotic integrity } \\ \text { IDAS } & \text { Invertebrate Data Analyses System, U.S. Geological Survey } \\ \text { LCCMR } & \text { Legislative-Citizen Commission on Minnesota Resources } \\ \text { MUID } & \text { soil map unit } \\ \text { N } & \text { nitrogen } \\ \text { NDS } & \text { nutrient-diffusing substrate } \\ \text { NWQL } & \text { National Water Quality Laboratory, U.S. Geological Survey } \\ \text { P } & \text { phosphorus } \\ \text { RIM } & \text { Reinvest in Minnesota } \\ \text { RPD } & \text { relative percentage difference } \\ \text { SSC } & \text { suspended-sediment concentration } \\ \text { STATSGO } & \text { State Soil Geographic database } \\ \text { SWCD } & \text { Soil and Water Conservation District } \\ \text { USDA } & \text { U.S. Department of Agriculture } \\ \text { USGS } & \text { U.S. Geological Survey } \\ \end{array}$





\title{
Water-Quality and Biological Characteristics and Responses to Agricultural Land Retirement in Three Streams of the Minnesota River Basin, Water Years 2006-08
}

\author{
By Victoria G. Christensen, Kathy E. Lee, Christopher A. Sanocki, Eric H. Mohring, and Richard L. Kiesling
}

\section{Abstract}

Water-quality and biological characteristics in three streams in the Minnesota River Basin were assessed using data collected during water years 2006-08. The responses of nutrient concentrations, suspended-sediment concentrations, and biological characteristics to agricultural land retirement also were assessed. In general, total nitrogen, suspendedsediment, and chlorophyll- $a$ concentrations, and fish resource quality improved with increasing land retirement.

The Chetomba Creek, West Fork Beaver Creek, and South Branch Rush River subbasins, which range in size from about 200 to 400 square kilometers, have similar geologic and hydrologic settings but differ with respect to the amount, type, and location of retired agricultural land. Total nitrogen concentrations were largest, with a mean of 15.0 milligrams per liter $(\mathrm{mg} / \mathrm{L})$, in water samples from the South Branch Rush River, a subbasin with little to no agricultural land retirement; total nitrogen concentrations were smaller in samples from Chetomba Creek (mean of $10.6 \mathrm{mg} / \mathrm{L}$ ) and West Fork Beaver Creek (mean of $7.9 \mathrm{mg} / \mathrm{L}$ ), which are subbasins with more riparian or upland land retirement at the basin scale. Total phosphorus concentrations were not related directly to differing land-retirement percentages with mean concentrations at primary data-collection sites of 0.259 $\mathrm{mg} / \mathrm{L}$ in the West Fork Beaver Creek subbasin, $0.164 \mathrm{mg} / \mathrm{L}$ in the Chetomba Creek subbasin, and $0.180 \mathrm{mg} / \mathrm{L}$ in the South Branch Rush River subbasin. Temporal variation in water quality was characterized using data from in-stream waterquality monitors and storm-sediment data.

Fish data indicate better resource quality for the West Fork Beaver Creek subbasin than for other subbasins likely due to a combination of factors, including habitat quality, food resources, and dissolved oxygen characteristics. Index of biotic integrity (IBI) scores increased as local land-retirement percentages (within 50 and 100 meters of the streams) increased. Data and analysis from this study can be used to evaluate the success of agricultural management practices and land-retirement programs for improving stream quality.

\section{Introduction}

The Minnesota River Basin (fig. 1), located primarily in the State of Minnesota, is part of the Midwest Corn Belt, which is one of the most productive and intensively managed agricultural regions in the world. Some agricultural practices use large quantities of chemical fertilizers and pesticides to maintain productivity. These fertilizers and pesticides have the potential for deleterious effects on stream quality.

Stream conditions are affected by interactions among physical and chemical factors at differing spatial scales. However, loss of riparian vegetation and natural land cover in the Minnesota River Basin has reduced habitat, modified hydrologic conditions, and changed water quality (Stark and others, 1996). Two important factors that affect physical, chemical, and biological conditions are local and watershed-wide land-cover characteristics. When agricultural land is taken out of production (retired), there may be important changes to water quality, aquatic habitat, in-stream temperature, and reduction of sediment and overland runoff. The effects of land retirement may differ depending on whether it is located adjacent to a stream (referred to in this report as riparian land retirement) or whether it is located in upland areas away from flowing water.

To address concerns about degradation of agricultural streams, Minnesota Governor Tim Pawlenty requested funding from the State of Minnesota and the U.S. Department of Agriculture to add new agricultural lands to the State's existing inventory of retired lands (Minnesota Board of Water and Soil Resources, 2007) to improve water quality and aquatic biology. However, no State or Federal programs existed to evaluate the effects of land-retirement programs or large-scale agricultural management practices on water quality and aquatic biology. Furthermore, the efficacy of prioritizing retired lands within a given basin is unknown.

Several small-scale agricultural management practices, such as crop-residue management and conservation tillage, have been analyzed. Land-use and agricultural-practice changes at the farm-field scale have shown promise in reducing nonpoint sources of contaminants, but a broader 


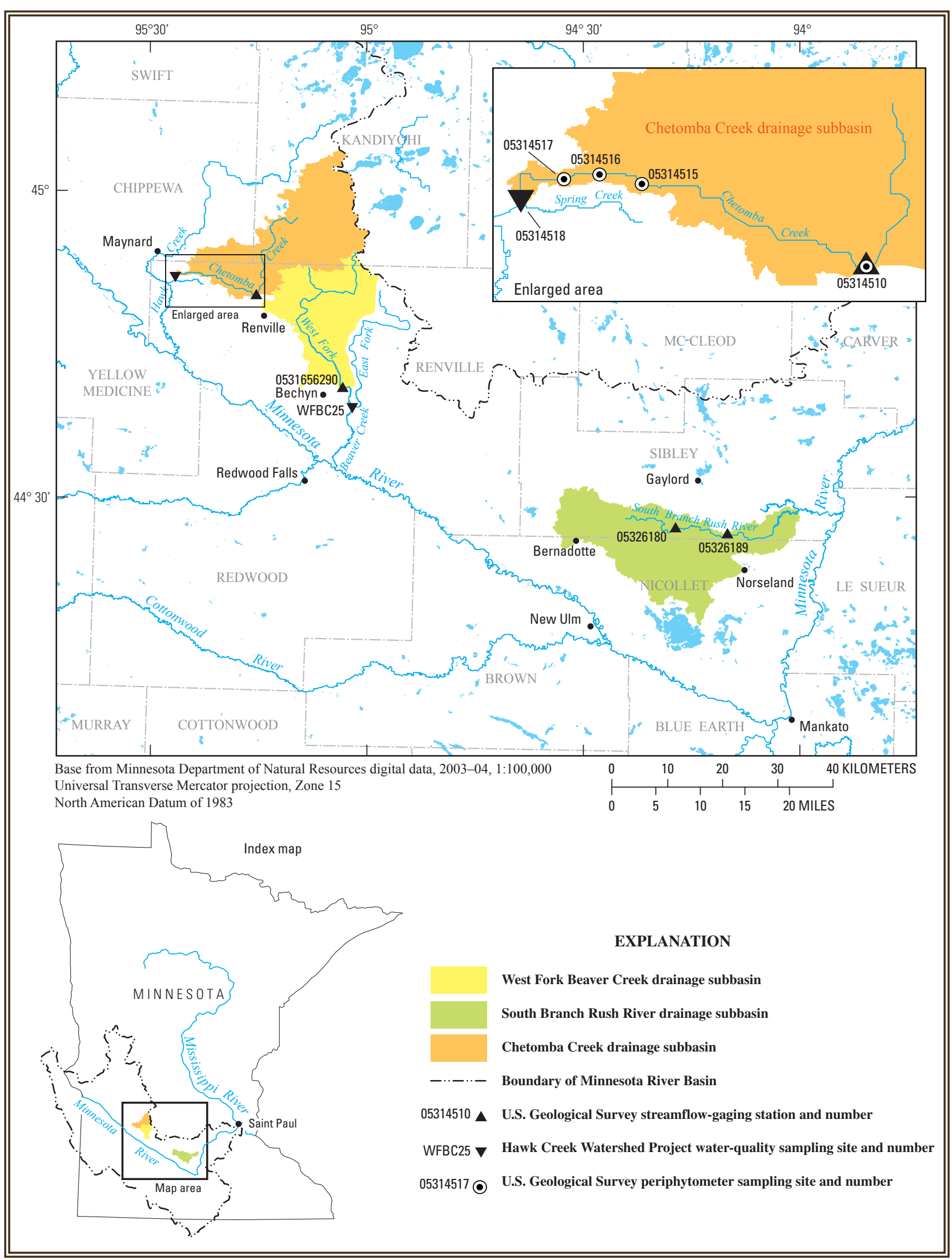

Figure 1. Location of the Minnesota River Basin, Chetomba Creek Basin, West Fork Beaver Creek Basin, and South Branch Rush River drainage subbasins, and location of streamflow-gaging stations and water-quality sampling sites. 
scale analysis of current land-use practices is needed to improve understanding of cumulative downstream effects on stream quality. It is difficult to link the effects of retired lands to water-quality benefits. Therefore, the U.S. Geological Survey (USGS), in cooperation with the Minnesota Board of Water and Soil Resources (BWSR), initiated a study to characterize water-quality and biological conditions and responses to agricultural land-retirement programs at a basin scale in three subbasins in the Minnesota River Basin that have varying amounts and locations of agricultural land retirement. This study is part of the USGS effort to provide an understanding of agricultural watershed processes and improve understanding of agricultural areas where land has been retired from agricultural production.

During this study, fully instrumented sampling sites were established with automated samplers, streamflowgaging stations, and water-quality monitors that can provide the infrastructure for future evaluations of agricultural land retirement and other agricultural management practices in the basins. Land owners, scientists, and local, State, and Federal agencies with responsibilities for land, water resources, and wildlife can use this information to improve management of natural resources in the Minnesota River Basin. Refining management practices through research and monitoring can lead to enhanced protection of the Nation's natural resources while sustaining economically viable agricultural production.

\section{Purpose and Scope}

The purpose of this report is to describe water-quality and biological characteristics and responses to agricultural land retirement in three streams of the Minnesota River Basin during water years 2006-08. Specific purposes of this report are to:

1. Describe streamflow, water-quality, and biological conditions for Chetomba Creek, West Fork Beaver Creek, and South Branch Rush River;

2. Describe seasonal variability of stream quality for Chetomba Creek, West Fork Beaver Creek, and South Branch Rush River;

3. Describe within-basin variability by using additional data from collection sites in Chetomba Creek and South Branch Rush River; and

4. Describe spatial variability in water-quality and biological conditions in comparison to the degree and location of agricultural land retirement.

Water-quality properties and constituents analyzed were physical properties, major ions, nutrients, pesticides, wastewater compounds, and sediment. Biological measurements and analyses included physical habitat characterization, benthic algae collection, benthic invertebrate collection, fish collection, measurement of dissolved oxygen, and phytoplankton chlorophyll- $a$ determination. Data for major ions, pesticides, and wastewater compounds are not discussed in this report. They are provided in the 2006 USGS Water-Data Report (U.S. Geological Survey, 2007).

For purpose 1, water-quality and biological data were collected at primary data-collection sites. Primary datacollection sites included in this report are USGS streamflowgaging stations located on Chetomba Creek (site 05314510), West Fork Beaver Creek (site 0531656290), and South Branch Rush River (site 05326189) (fig. 1). For purpose 2, continuous data were collected by using in-stream monitors, and multiple sediment samples were collected during storms. For purpose 3, secondary sites in Chetomba Creek and the South Branch Rush River were established, and a longitudinal synoptic survey of biomass accumulation in Chetomba Creek was conducted. Secondary sites were the Chetomba Creek near Maynard (also called Judicial Ditch No. 1, site 05314518, fig. 1), the South Branch Rush River at County Road 8 near Bernadotte (site 05326180, fig. 1), and the West Fork Beaver Creek site WFBC25 (fig. 1), which was established and maintained by the Hawk Creek Watershed Project. Data from West Fork Beaver Creek site WFBC25 were not included in this report, but data collected from this site were used for site selection and were reviewed periodically by project management during the study. Additional sites were established in Chetomba Creek (see enlarged area, fig. 1) for the longitudinal synoptic survey of biomass accumulation. The results of the survey of algal biomass accumulation are described to help assess within-basin changes in primary productivity.

\section{Background}

This section of the report describes the Minnesota River Basin and selected tributaries within the basin. Effects of agricultural land retirement and tile drains on streams also are described.

\section{Description of Minnesota River Basin}

The Minnesota River originates near the western border of Minnesota, flows southeast to Mankato (fig. 1), and then turns northeast where it joins the Mississippi River at Saint Paul. The Minnesota River Basin is located primarily within south-central Minnesota (fig. 1) in an area characterized by dissected till plains, undulating till plains, lake plains, and glacial moraines (Stark and others, 1996). The Minnesota River Basin consists of 12 tributary-river basins (Payne, 1994). The Chetomba Creek, West Fork Beaver Creek, and South Branch Rush River subbasins are part of the till plains and drumlins physiographic province (Payne, 1994). Rock formations are not well exposed in much of the study area because of a lack of topographic relief and the easily erodible 
nature of the rocks. Very little bedrock is exposed at the surface (Ojakangas and Matsch, 1982) except in places along the Minnesota River. Magner and Alexander (1993) reported that basin geology was an important determinant of water quality in the Minnesota River.

Precipitation and evapotranspiration affect runoff. Mean annual precipitation in the Minnesota River Basin is about 61 centimeters (cm; University of Minnesota, 2009) and generally increases from about $56 \mathrm{~cm} / \mathrm{yr}$ in the western part of the basin to about $79 \mathrm{~cm} / \mathrm{yr}$ in the eastern part of the basin. Runoff is the depth to which the drainage area would be covered if all the runoff was distributed evenly (Payne, 1994, p. 5). Runoff ranges from about 5 to $15 \mathrm{~cm} / \mathrm{yr}$ (Winterstein and others, 1993) and dominates streamflow during spring and early summer. Larger runoff values in the eastern part of the basin indicate that this part of the basin delivers more water to the Minnesota River per unit area than does the western part.

Streamflow varies seasonally throughout Minnesota because of freezing during the winter, thawing during the spring, and seasonal variations in precipitation and runoff (Tornes, 1986). Groundwater discharge dominates in the late summer when precipitation begins to decrease and continues through the fall and winter depending on rainfall and snowmelt. However, groundwater discharge varies across the Minnesota River Basin depending on local geology.

Agriculture has a major effect on water quality in the Minnesota River Basin (Battaglin and Goolsby, 1999). Intensive use of agricultural chemicals has resulted in nonpoint-source contamination of surface water throughout the basin. Agricultural activities, such as channelization and the installation of tile drains, also have changed local hydrologic conditions. Farm ponds that have been built for recreational purposes or to provide water for livestock may receive runoff, trap sediment, or interact with groundwater.

Suspended sediment is a concern because it can bind and transport harmful substances such as nutrients and pesticides (Baker, 1980). One source of sediment in streams of the Minnesota River Basin is from soil particles exposed by cultivation that are loosened by raindrops and sheet and rill erosion and then carried to receiving water (Tornes, 1986). Other sources of suspended sediment are construction activities and erosion of streambanks and streambeds. Most of the sediment in the basin is transported during spring. Tornes (1986) reported that almost one-fourth of the annual sediment load for 19 stream sites in Minnesota was carried during April.

Fish found in the Mississippi River Basin (which includes the Minnesota River Basin) include both warm- and cool-water species. The Minnesota River Basin has 84 native species of fish (Stark, 1997). Biological communities and ecological conditions are affected by chemical and physical conditions in rivers, and drainage of wetlands, loss of riparian vegetation, and channel straightening in the Minnesota River Basin have reduced habitat (Stark, 1997).

\section{Description of Selected Subbasins}

The Chetomba Creek, West Fork Beaver Creek, and South Branch Rush River subbasins were selected for analysis of the effects of agricultural land retirement on water-quality and biological conditions. Fields that are along the ditches and streams in the selected subbasins commonly are plowed as close as possible to the break in slope of the ditch as shown in figure 2. However, ditches constructed after 1971 require a 1-rod (approximately $5.0 \mathrm{~m}$ ) setback. Minnesota Statutes Chapter 103E states that this grass strip must extend from the ditch bank on both sides. More information on ditch setback requirements is available at https://www.revisor.leg.state. $\mathrm{mn} . u s /$ statutes/?id=103E.021\&year=2008. Ditches with this grass strip were promoted by some local agencies to reduce sediment loading.

Chetomba Creek is located primarily within Kandiyohi and Renville Counties, with a small part of the basin in Chippewa County. The streamflow-gaging station at Chetomba Creek near Renville (site 05314510; fig. 1) has a contributing drainage area of 308 square kilometers $\left(\mathrm{km}^{2}\right)$. Land use in the Chetomba Creek subbasin is primarily agricultural (cultivated crops and pasture, hay, or grassland; table 1).

Agricultural chemicals applied to enhance crop production in the Chetomba Creek subbasin include commercial fertilizers (such as nitrate, ammonia, and phosphorus) and pesticides (U.S. Department of Agriculture, 2002). Manure also is applied as a fertilizer. In Chippewa, Kandiyohi, and Renville Counties, approximately 55-60 percent of the farms are treated with fertilizer, including manure (table 2).

West Fork Beaver Creek is primarily within Renville County. The drainage area is approximately $247 \mathrm{~km}^{2}$ at the streamflow-gaging station near Bechyn (0531656290, fig. 1). A secondary sampling site (WFBC25; fig. 1) is located downstream from the streamflow-gaging station and is sampled and maintained by the Hawk Creek Watershed Project. In Renville County, 60.4 percent of the farms in the county are treated with fertilizer (table 2).

South Branch Rush River is primarily within Sibley County and drains an area of $212 \mathrm{~km}^{2}$ at the streamflowgaging station near Norseland (site 05326189). A secondary site (05326180, fig. 1) on the South Branch of the Rush River was established in 2007 to collect data for within-basin comparisons. In Sibley County, 73.8 percent of the farms are treated with fertilizer (table 2).

\section{Effects of Land Retirement on Streams}

Much of the Minnesota River Basin is planted in row crops, such as corn and soybeans, leaving these fields bare for part of the year, increasing erosion, and contributing to the sediment load of the Minnesota River. Application of fertilizers adds to the contaminant concerns in the river. Riparian buffers (the zone of vegetation adjacent to the 


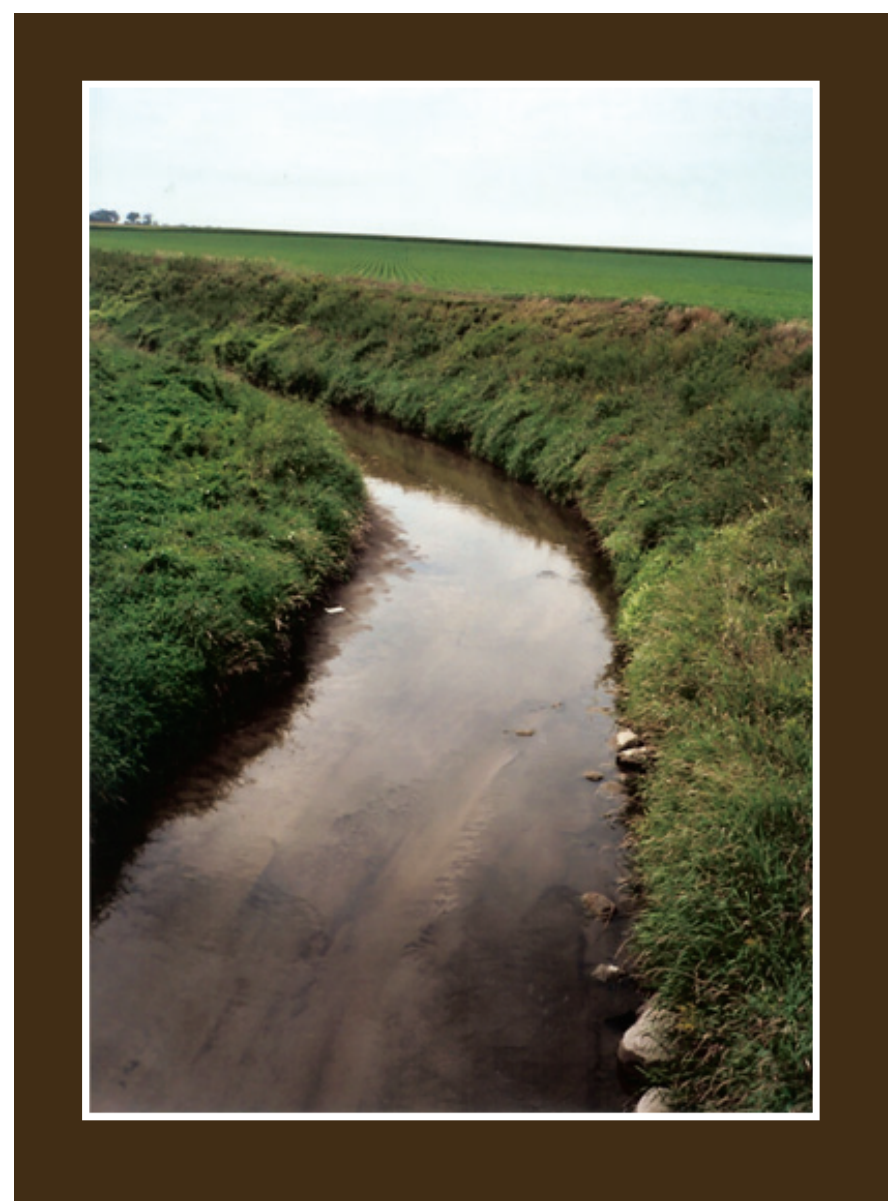

Figure 2. South Branch Rush River near Norseland, September 2005. stream) have been proposed as an effective method of buffering or protecting a stream and its aquatic organisms against excess nutrients and sediment. Riparian buffers attenuate nutrients through plant uptake, slow overland sediment transport, and provide shade for stream channels. Stream shading is a factor in algal production (Allan, 1995) and nutrient uptake.

In addition to riparian buffers, some upland areas in the Minnesota River Basin that are environmentally sensitive have been taken out of production. Upland land retirement works in much the same way as riparian buffers - trapping nutrients and sediment in the vegetation before it can runoff into a water body or by protecting the groundwater by trapping nutrients or contaminants in the subsurface. Land adjacent to wetlands, marginal pastureland, hillsides, and areas with substantial risk of groundwater contamination qualify for certain land-retirement programs. Typically, however, landretirement programs require the land to be adjacent to a stream or wetland. In this report, land that is adjacent to a stream or river is considered riparian; upland areas are those that are not directly adjacent to a river or stream but may be connected to a wetland.

Several programs were designed to encourage the retirement of agricultural land and are currently practiced in the Minnesota River Basin. Three of those programs account for the majority of the agricultural land retirement in the basin - the Conservation Reserve Program (CRP), the Reinvest in Minnesota (RIM) program, and the Conservation Reserve Enhancement Program (CREP).

The CRP was designed to retire cropland from production. It was established by the Food Security Act of

Table 1. Land-use types and percentages in the Chetomba Creek, West Fork Beaver Creek, and South Branch Rush River subbasins, 2001.

[Data from the National Land Cover Database 2001 (U.S. Geological Survey, 2003)]

\begin{tabular}{lccc}
\hline \multicolumn{1}{c}{ Land-use type } & Chetomba Creek & $\begin{array}{c}\text { West Fork Beaver } \\
\text { Creek }\end{array}$ & $\begin{array}{c}\text { South Branch Rush } \\
\text { River }\end{array}$ \\
\hline Cultivated crops & 87.9 & 84.8 & 88.3 \\
Pasture, hay, or grassland & 1.3 & 1.6 & .5 \\
Forest or shrub & 1.3 & 1.1 & 1.3 \\
Open water or wetlands & 3.6 & 6.7 & 4.7 \\
Developed or barren land & 6.0 & 5.7 & 5.1 \\
\hline
\end{tabular}


Table 2. Estimates of fertilizer application for selected counties in the Minnesota River Basin, 2002.

[Modified from U.S. Department of Agriculture (2002); $\mathrm{km}^{2}$, square kilometers]

\begin{tabular}{lcccc}
\hline County & $\begin{array}{c}\text { Area treated } \\
\text { with commercial } \\
\text { fertilizer }\left(\mathbf{k m}^{2}\right)\end{array}$ & $\begin{array}{c}\text { Area treated with } \\
\text { manure }\left(\mathbf{k m}^{2}\right)\end{array}$ & $\begin{array}{c}\text { Total area treated } \\
\left(\mathbf{k m}^{2}\right)\end{array}$ & $\begin{array}{c}\text { Percentage of county } \\
\text { area (farms only) } \\
\text { treated with fertilizer }\end{array}$ \\
\hline Chippewa & 693 & 57 & 750 & 54.5 \\
Kandiyohi & 749 & 166 & 915 & 55.4 \\
Nicollet & 552 & 116 & 668 & 64.2 \\
Renville & 1,434 & 188 & 1,622 & 60.4 \\
Sibley & 883 & 131 & 1,014 & 73.8 \\
\hline
\end{tabular}

${ }^{1}$ Fertilizer application to land other than farms (for example, golf courses and residences) was not included. Fertilizer in this calculation includes both commercial fertilizer and manure.

1985. Under the program, the U.S. Department of Agriculture (USDA) establishes contracts with voluntary agricultural producers to retire highly erodible and environmentally sensitive cropland and pasture from production for 10-15 years (U.S. Department of Agriculture, 2004). Producers enrolled in CRP plant long-term conservation cover crops for the duration of the contract. The primary goal of CRP is to reduce soil erosion (Osborn and others, 1995). It is thought that enrollment of agricultural lands in land-retirement programs such as CRP will improve the water quality of streams by decreasing the amount of soil exposed to erosion and reducing sediment and nutrients transported to the stream.

Figure 3 shows how a retired agricultural field, such as a CRP field planted in native grasses, acts as a trap for nutrients, sediment, and pesticides. In the retired agricultural field, suspended sediment that is carried by runoff enters a grass filter, and the resulting reduction in velocity causes the transport capacity of the runoff to decrease, which allows sediment deposition to occur (Wilson and others, 1997). Root systems for native prairie grasses also tend to be deeper than row-crop roots and, therefore, trap nutrient and pesticides flowing with the subsurface flow.

The RIM program was established in 1986 and is administered through the Minnesota Board of Water and Soil Resources (BWSR) in partnership with local Soil and Water Conservation Districts (SWCDs). The primary goal of RIM is to improve fish and wildlife habitat and water quality and to reduce soil erosion through conservation activities on private lands. The RIM program enrolls a variety of land types into permanent conservation easements. The program focuses on enrolling highly erodible land, riparian land, and wetland restorations. In addition to an enrollment payment, RIM provides funds to share the cost of establishing conservation practices or wildlife habitat.

Another conservation reserve program designed to improve water quality is the CREP. The CREP establishes funding support and partnerships among USDA, State, and nongovernment organizations. The primary goal of CREP is improvement in drinking and surface-water quality and wildlife habitats (Allen, 2005). The difference between CRP and CREP is that CREP focuses on State-defined priorities. The Minnesota River CREP was established in 1998. Its primary area of focus was the Minnesota River Basin, and its key environmental objective was to improve water quality and wildlife habitat in the basin. The Minnesota River CREP uses the resources of both the CRP and RIM reserve programs and combines permanent conservation easements with CRP contracts. The combined program results in more than 40,000 hectares of permanent conservation easements in the Minnesota River Basin (Minnesota Board of Water and Soil Resources, 2004) that are targeted for riparian cropland and wetland restorations.

Research has shown that conservation reserve programs provide improvements in water quality and benefits to fish and wildlife (Haufler, 2005). Mayer and others (2006) concluded that riparian buffers are effective at improving water quality by reducing nitrogen levels in groundwater and streams. Buffers can help moderate peak flows and maintain stream base flow, which in turn help moderate water temperature (Stewart and others, 2006).

Numerous wildlife species have been documented to use CRP land (Burger, 2005; Clark and Reeder, 2005), and benefits to fish through enhanced water quality have been documented (Allen, 2005). The evidence of improvement 


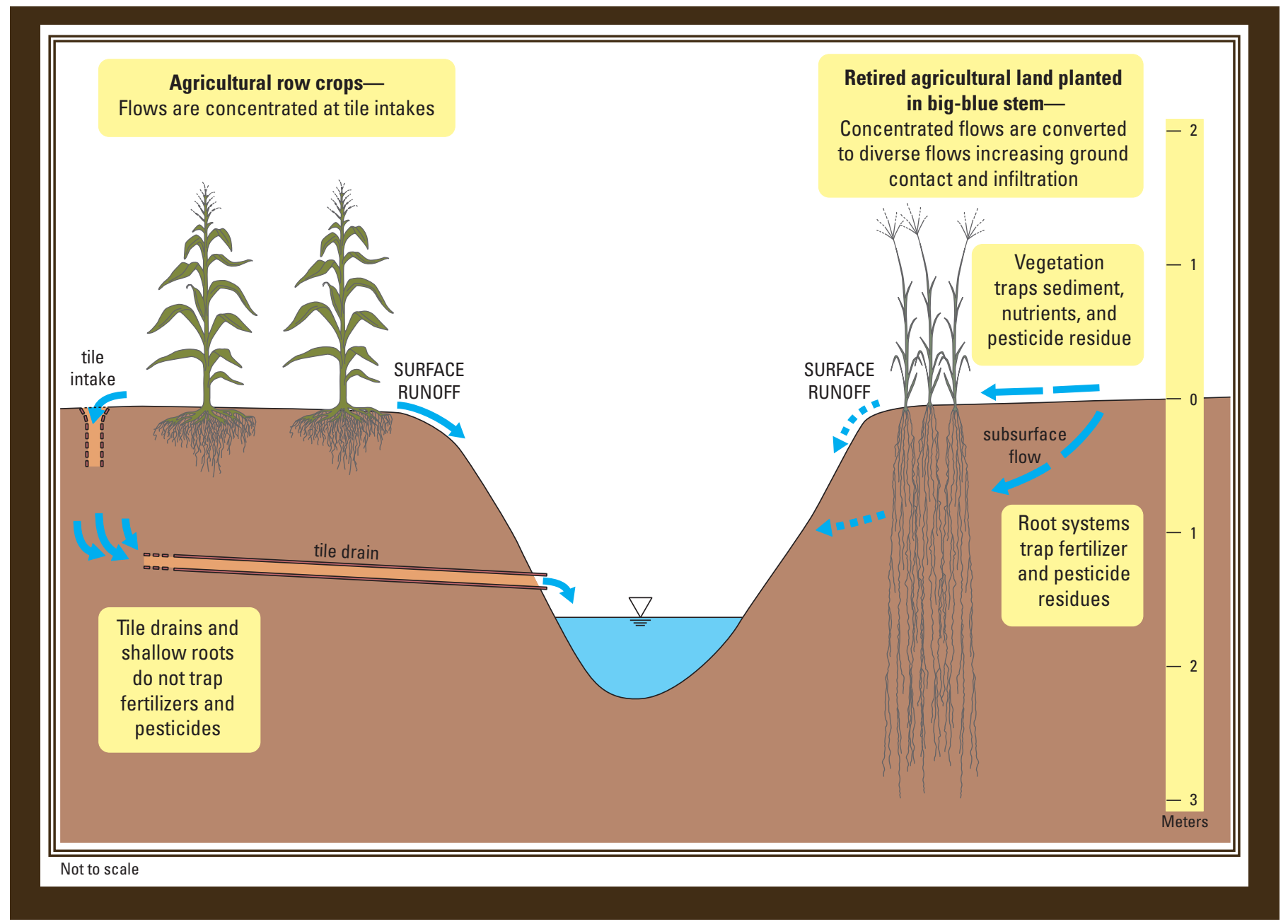

Figure 3. Surface flows for land in row crops and for retired agricultural land in a conservation reserve program.

is particularly abundant for bird populations. Ferrand and Ryan (2005) reported that bird populations had increases in reproduction and population that were attributable to the CRP in the Midwest. Johnson (2005) also found benefits to birds associated with the CRP when compared to cropland in the northern Great Plains. Reynolds (2005) reported that the CRP in the Prairie Pothole Region (located in the northcentral United States) was estimated to produce 2.2 million ducks per year.

Although benefits have been reported by the previously mentioned authors, responses of wildlife to the CRP vary (Haufler, 2005), and studies have been confined to small areas (Johnson, 2005). Thus, more studies are needed to look at conservation programs on a wider or basin scale (Allen, 2005).

\section{Effects of Tile Drains on Streams}

Because of the poorly drained soils and consequential low infiltration rates in much of the Minnesota River Basin, tile drains are used to help drain the water from agricultural fields.
A drainage tile is a subsurface pipe designed for the removal of excess water from fields without the longer residence time of groundwater storage. This may reduce ponded water and flood damage to fields and draws oxygen into the soil. These tile drains also provide a direct path for surface water and any associated contaminants to reach drainage ditches and streams (Wilson and others, 1997). Because the selected subbasins have substantial runoff potential, when this is combined with the tile drains, rapid fluctuations in streamflow occur during precipitation (ZumBerge and others, 2003).

Figure 3 shows how hydrology is modified when a typical Minnesota River Basin field is planted in row crops and tile drains are installed. Tile drains affect hydrology by concentrating surface flows and transporting them directly to the stream or drainage ditch. Row crops typically have shallow root systems that reduce their ability to trap nutrients and pesticides in subsurface flow.

Tile drains have many advantages and disadvantages. The water-quality effect of tile drains is mainly an increase in nitrate concentrations and a decrease in sediment concentrations. One study indicated that tile drains were 
the major contributor of nitrate to drainage ditches (Baker and others, 2006, p. 24). The Minnesota Department of Agriculture has completed research on different types of conservation drainage that may prevent certain contaminants, mainly nitrate, from entering the drainage water. Wilson and others (1997) concluded that the effect of tile drains depends more on the type of tillage (for example, no till compared to conventional tillage) than on other factors. The University of Minnesota is researching the effect of traditional open-tile inlets compared to "blind" or "rock" inlets (University of Minnesota, 2009). These and other alternative surface inlets may have differing effects on hydrology, water quality, and agricultural productivity.

On a basin scale, tile drains may have a long-term effect on streamflow, which may cause long-term changes in the concentrations of dissolved constituents. Tomer and others (2003) concluded that agricultural and wetland best management practices are needed to achieve water-quality goals in tile-drained watersheds. Tile lines typically are broken when agricultural land is retired (Stephanie Klamm, Hawk Creek Watershed District, oral commun., 2008), and certain land-retirement programs require tiles to be plugged or broken when land is retired (U.S. Department of Agriculture, 2001, 2007a). Some land-retirement programs restrict eligibility if tile lines would cause runoff to bypass the retired land. For example, the CREP denies eligibility for sites where more than 50 percent of field runoff bypasses a proposed filter strip because of tile or surface intakes (U.S. Department of Agriculture, 2007b). When the tile-drain guidance on landretirement eligibility and land-retirement site selection is followed, riparian buffers and agricultural land retirement may mitigate some of the effects of the tile drains on a basin scale.

\section{Methods}

This section describes the methods used for site selection, determination of the retired agricultural land distribution in the selected subbasins, measurement of streamflow, and real-time monitoring of water quality. Methods used to collect and analyze samples for water quality and biological charactertization also are presented.

\section{Site Selection and Determination of Retired Agricultural Land Distribution}

The purpose of this study was to characterize waterquality and biological conditions and to describe the effects of retired agricultural lands on the water-quality and biological conditions of streams in the Minnesota River Basin. The information from the study was to be used to enhance prioritization of future land retirements. The initial task was to select three subbasins for study. Ideally, these subbasins would represent varying degrees of land retirement with one of the subbasins having primarily riparian land retirement and one subbasin having primarily upland land retirement. One challenge was finding an appropriate subbasin with a substantial amount of upland land retirement. Few subbasins in the Minnesota River Basin had substantial land retirement, and many of those that did had factors that precluded them.

A set of 17 selection criteria was considered to prioritize the subbasins within the Minnesota River Basin (table 3). The selection of three subbasins required that differences for most criteria listed in table 3 be minimal and that differences in land retirements be maximized.

Although some of the criteria considered for site selection are self-explanatory, others warrant further explanation. For example, it was desirable to have no in-line lakes (criterion 2) or dams (criterion 13) because these affect not only the hydrology but also nutrient conditions, algal production, and fish movement. The availability of streamflow-gaging stations (criterion 14) and whether current (2006) waterquality sampling was occurring at the site (criterion 15 ) were important in site selection because of the value that additional data (both current and historical) would provide to the study. In addition, current sampling at a site would increase feasibility of storm sampling and reduce costs of collection.

Cluster analysis was used to group subbasins with similar soils (criterion 4, table 3). Cluster analysis (Tibco Spotfire $\mathrm{S}+8.1,2008)$ is a method of grouping objects of a similar kind into respective categories. In this case, the soil map units (MUIDs) in the geographic information system (GIS) coverage for the State Soil Geographic database (STATSGO) have assigned percentages of seven hydrology classes (Natural Resources Conservation Service, 2003):

1. Hydrology class A: substantial infiltration rates; soils are deep, well-drained to excessively drained sand and gravel.

2. Hydrology class A/D: drained/undrained hydrology class of soils that can be drained and are classified.

3. Hydrology class B: moderate infiltration rates; deep and moderately deep, moderately well and welldrained soils with moderately coarse textures.

4. Hydrology class B/D: drained/undrained hydrology class of soils that can be drained and are classified.

5. Hydrology class C: slow infiltration rates; soils with layers impeding downward movement of water, or soils with moderately fine or fine textures.

6. Hydrology class C/D: drained/undrained hydrology class of soils that can be drained and classified.

7. Hydrology class D: very slow infiltration rates; soils are clayey, have a high water table, or are shallow to an impervious layer.

For this study, the seven hydrologic classes plus a "blank" hydrology class were reclassified into six hydrologic classes-A, B, C, D, M, and W: 
Table 3. Criteria considered for selection of sites for study of water-quality and biological responses to agricultural land retirement, Minnesota River Basin.

\begin{tabular}{ll}
\hline Number & \multicolumn{1}{c}{ Description of criterion } \\
\hline 1 & $\begin{array}{c}\text { Drainage area similar among all three subbasins and between about } 250 \text { and } 775 \text { square kilometers to assure perennial } \\
\text { streams. }\end{array}$ \\
2 & No major in-line lakes or reservoirs and less than 5 percent lakes in the subbasin. \\
3 & Slopes similar among all three subbasins and less than 0.2 meters per kilometer (to avoid steep-slope stream reaches). \\
4 & Similar soil hydrogroup among all three subbasins determined on the basis of cluster analysis. ${ }^{1}$ \\
5 & Climate (evapotranspiration and rainfall) similar among all three subbasins. \\
6 & Similar sinuosity/drainage network among all three subbasins. \\
7 & Similar amount of wetlands and agricultural land use in all three subbasins. \\
8 & Proximity of retired lands to the stream. \\
9 & Similar riparian shading conditions among all three subbasins (shading is a factor in algal production and nutrient \\
10 & uptake). \\
11 & Similar in-stream macrophyte characteristics among all three subbasins (macrophytes affect nutrient concentrations). \\
12 & No point sources including wastewater treatment plants and confined animal feeding operations within subbasin. \\
13 & Similar streambed substrate in all three subbasins. \\
14 & No dams that restrict fish movement in subbasin. \\
15 & Availability of streamflow-gaging stations (including historical streamflow and water-quality data) in subbasin. \\
16 & Current (2006) water-quality sampling occurring at site within subbasin. \\
17 & Feasibility of site access. \\
\hline
\end{tabular}

${ }^{1}$ Cluster analysis is described in the text.

1. Hydrology class A was reclassified into hydrology class A.

2. Hydrology class $\mathrm{A} / \mathrm{D}$ was reclassified into hydrology class M (mixed group).

3. Hydrology class B was reclassified into hydrology class B.

4. Hydrology class $\mathrm{B} / \mathrm{D}$ was reclassified into hydrology class M (mixed group).

5. Hydrology class $\mathrm{C}$ was reclassified into hydrology class $\mathrm{C}$.

6. Hydrology class $\mathrm{C} / \mathrm{D}$ was reclassified into hydrology class D.

7. Hydrology class D was reclassified into hydrology class D.
8. The blank hydrology class was reclassified into hydrology class W (this group was added to fill in the areas with open water and where no hydrology class was assigned).

The GIS coverage of the STATSGO reclassified hydrology classes was overlain onto the approximately 1,600 subbasins within the Minnesota River Basin. Each of the 1,600 subbasins was classified with percentages of each hydrology class on the basis of the area of each MUID that fell within each subbasin. Each subbasin may have contributing subbasins that make up the total drainage area for that subbasin. All reclassed hydrology class fields were summed to get a total for each subbasin and all contributing subbasins. The three subbasins selected for study-Chetomba Creek subbasin, West Fork Beaver Creek subbasin, and South Branch Rush River subbasin - were in the same hydrologic class (the same cluster) and have similar geologic and hydrologic settings. These basins had soils with slow infiltration rates, layers of 
soil that impede downward movement of water, or soils with moderately fine or fine textures.

One site was selected in each subbasin for intensive sampling and instrumentation. The three primary datacollection sites were USGS streamflow-gaging stations located on Chetomba Creek near Renville (site 05314510, fig. 1), West Fork Beaver Creek at 320 Street near Bechyn (site 0531656290, fig. 1), and South Branch Rush River at County Road 63 near Norseland (site 05326189, fig. 1).

The subbasins differ with respect to the degree, amount, and location of agricultural land retirement (riparian, upland, and no land-retirement conditions) (table 4). Secondary sampling sites were established on Chetomba Creek (site 05314518, fig. 1) and South Branch Rush River (site 05326180 , fig. 1) for within-basin comparisons. The secondary sampling site in the Chetomba Creek subbasin, Chetomba Creek near Maynard is sometimes called Judicial Ditch No. 1 (site 05314518, fig. 1). Chetomba Creek was rerouted through Judicial Ditch No. 1 in the 1970s, making this site downstream from the Chetomba Creek site 05314510. The intervening drainage area between sites 05314510 and 05314518 has few tributary ditches or streams and substantial land retirement (table 4).

Most land-retirement data were obtained in 2007 from the Farm Services Agency (FSA) in Saint Paul and included a GIS coverage of land with CRP contracts. Landretirement data also were obtained for the CREP, RIM, and other programs, including Wildlife Management Areas and Waterfowl Production Areas that have small amounts of retired agricultural land. CREP and RIM data were obtained from the Minnesota Board of Water and Soil Resources; Wildlife Management Area data were obtained from the Minnesota Department of Natural Resources; and Waterfowl Production Area data were obtained from the U.S. Fish and Wildlife Service.

To determine the intensity of retired agricultural land, the percentage of retired land within $300,200,100$, and $50 \mathrm{~m}$ of the streams in the selected subbasins was determined (table 4). In the literature, these areas surrounding a stream have been called "influence zones" (see, for example, Burcher, 2009). An aerial photograph overlain with retired agricultural land and lines of equal distance, delineating influence zones in a small area of the Chetomba Creek subbasin, is shown in figure 4. For this study, the buffer function within GIS was used to delineate zones of $300,200,100$, and $50 \mathrm{~m}$ surrounding all the streams and tributaries in each subbasin.

\section{Streamflow Measurement}

Stream water-surface elevation (stage) was measured at the three streamflow-gaging stations with pressure transducers (Buchanan and Somers, 1968). Stage data at the three primary sites were electronically recorded and transmitted by satellite in 15-minute increments to a downlink site and then to the computer at the USGS office in Mounds View, Minn. Streamflow measurements were made approximately every 6 weeks using methods described in Buchanan and Somers (1969). A stage-streamflow relation for each gaging station was developed on the basis of streamflow measurements and the stage of the stream at the time of measurement (Kennedy, 1983, 1984). Streamflow and stage data then were disseminated on the World Wide Web at http://waterdata. usgs.gov/. Streamflow and other water data in this report are compared and analyzed in terms of water year. The water year is a 12-month period that begins on October 1 and ends on September 30. The water year is designated by the year in which it ends. For example, the 2006 water year begins October 1, 2005, and ends on September 30, 2006.

\section{Real-Time Water-Quality Monitoring}

Continuous, real-time water-quality monitoring was used at the three streamflow-gaging stations to document physical properties of the water. Specific conductance, $\mathrm{pH}$, water temperature, turbidity, and dissolved oxygen were monitored in real time during the 2006-08 growing seasons (generally from April through August). The water-quality monitors installed at the three streamflow-gaging stations have multiple sensors that measure physical properties of water quality. Generally, the same type of sondes and probes were used throughout the network to minimize differences. The exception was the dissolved oxygen probes. Newer optical dissolved oxygen probes were used to replace Clark cell probes during 2008. The sondes were connected to datacollection platforms at each streamflow-gaging station, and data were transmitted by satellite to a downlink site and the computer at the USGS office in Mounds View, Minn. The sensors were calibrated, and the data were quality assured according to methods presented in Wagner and others (2006).

\section{Sample Collection and Analysis}

Water-quality and biological samples were collected and analyzed for this study. Water-quality measurements included onsite physical properties, major ions, nutrients, pesticides, wastewater compounds, and sediment. Major ions, pesticides, and wastewater compounds were collected during the 2006 water year, and results were published in the 2006 Annual Data Report found on the Web at http://mn.water. usgs.gov/publications/pubswdr.html; physical properties, nutrients, and sediment are discussed in a following section. Biological samples and analyses included physical habitat characterization, benthic algal samples, invertebrate samples, fish samples, and a survey of biomass accumulation. 


\begin{tabular}{|c|c|c|c|c|c|c|c|}
\hline \multirow[b]{2}{*}{ Site name } & \multirow[b]{2}{*}{$\begin{array}{c}\text { U.S. } \\
\text { Geological } \\
\text { Survey site } \\
\text { number (fig. 1) }\end{array}$} & \multirow[b]{2}{*}{$\begin{array}{l}\text { Drainage } \\
\text { area }\left(\mathbf{k m}^{2}\right)\end{array}$} & \multicolumn{5}{|c|}{ Percentage of agricultural land retirement } \\
\hline & & & Basin & $\begin{array}{l}\text { 300-m } \\
\text { influence } \\
\text { zone }^{a}\end{array}$ & $\begin{array}{l}\text { 200-m } \\
\text { influence } \\
z^{20 n e^{a}}\end{array}$ & $\begin{array}{c}100-\mathrm{m} \\
\text { influence } \\
\text { zone }^{\mathrm{a}}\end{array}$ & $\begin{array}{c}\text { 50-m influence } \\
\text { zone }^{\mathrm{a}}\end{array}$ \\
\hline Chetomba Creek near Renville & 05314510 & $308^{\mathrm{b}}$ & 2.72 & 3.19 & 3.54 & 4.31 & 5.01 \\
\hline $\begin{array}{l}\text { Chetomba Creek near Maynard } \\
\text { (Judicial Ditch No. 1) }\end{array}$ & 05314518 & 396 & 3.86 & 4.66 & 5.33 & 6.83 & 8.18 \\
\hline $\begin{array}{l}\text { West Fork Beaver Creek at } 320 \\
\text { Street near Bechyn }\end{array}$ & 0531656290 & 247 & 4.32 & 6.91 & 8.16 & 10.08 & 10.99 \\
\hline $\begin{array}{l}\text { South Branch Rush River } \\
\text { at County Road } 8 \text { near } \\
\text { Bernadotte }\end{array}$ & 05326180 & 175 & 1.43 & 1.72 & 2.35 & 4.01 & 6.29 \\
\hline $\begin{array}{l}\text { South Branch Rush River } \\
\text { at County Road } 63 \text { near } \\
\text { Norseland }\end{array}$ & 05326189 & 212 & 1.71 & 2.21 & 2.93 & 4.59 & 6.80 \\
\hline
\end{tabular}

${ }^{a}$ The influence zones are defined by the percentage of retired land within 300,200,100, and 50 meters on either side of the stream and its tributaries throughout each subbasin.

${ }^{\mathrm{b}}$ Revised numbers are based on a hydro-enhanced digital elevation model.

\section{Water-Quality Sample Collection and Analysis}

Water-quality samples were collected manually according to methods described in the USGS National Field Manual (Wilde and Radke, 1998) and with automated samplers. Samples for analysis of water-quality constituents were collected using equal-width increment (EWI) techniques with the exception of samples collected with automated sampling equipment and a few grab samples.

Nutrient samples were analyzed at the USGS National Water Quality Laboratory (NWQL) in Denver, Colo., by using methods described by Fishman (1993) and Patton and Kryskalla (2003). Suspended-sediment samples were collected by using methods described by Guy and Norman (1970) and analyzed for suspended-sediment concentration (SSC) at the USGS Sediment Laboratory in Iowa City, Iowa, by using methods described by Guy (1977). In addition, water also was analyzed onsite with a second water-quality monitor at the time of collection for specific conductance, $\mathrm{pH}$, water temperature, turbidity, and dissolved oxygen.
Chlorophyll- $a$ concentrations were analyzed in seston (water-column algae) at the NWQL using protocols outlined in Arar and Collins (1997). A water sample for analysis of chlorophyll- $a$ concentrations was collected concurrently with water for nutrient and SSC analyses and was filtered through a 47-millimeter ( $\mathrm{mm})$ glass-fiber filter. The filter was folded into quarters, wrapped in aluminum foil, placed in a labeled Petri dish, placed in a plastic bag, and frozen on dry ice for shipment to NWQL (Moulton and others, 2002).

The strategy for water-quality sampling was to collect four routine samples and three storm samples for each of the primary sites (sites 05314510,0531656290 , and 05326189 ; table 4; fig. 1). The plan was adjusted during the study due to the occasional malfunction of an autosampler or when fewer than three storms occurred during a sampling season. In general, the sampling scheme for the primary sites was similar among the sites, and sampling results were used for comparison of water-quality conditions among basins. For these comparisons among the basins, multiple storm samples collected with automated samplers were combined into a 


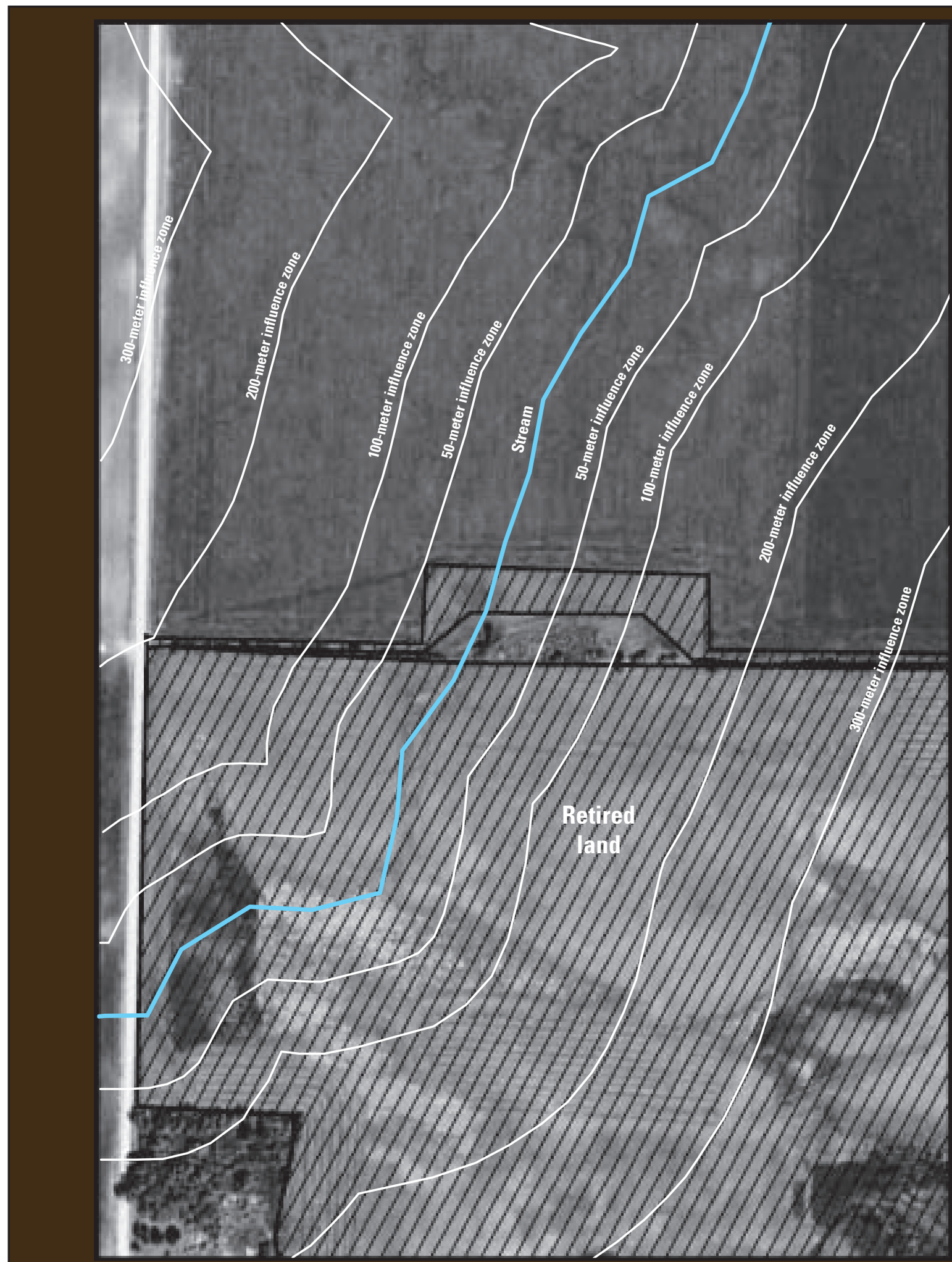

Base from U.S. Geological Survey digital data, 2009, 1:3,500

Aerial Imagery from Minnesota Farm Service Agency 1:3,500, 2008

Universal Transverse Mercator projection, Zone 15

North American Datum 1983

Figure 4. Retired agricultural land within a small portion of the 50-meter, 100-meter, 200-meter, and 300meter influence zones of the Chetomba Creek Basin. 
flow-weighted composite sample for a site so that only one sample was analyzed per storm.

Water-quality samples were collected from the secondary sampling sites on Chetomba Creek (site 05314518, fig. 1) and South Branch Rush River (site 05326180, fig. 1) to provide data to describe within-basin variability. These secondary sites were added after the study began, and therefore, fewer samples were collected from the secondary sites than from the primary sites. Because of this, data from secondary sites are not used to describe comparisons among the three subbasins but are used to characterize general water-quality conditions in the subbasins and for upstream-downstream water-quality comparisons for Chetomba Creek and South Branch Rush River. For upstream-downstream comparisons at Chetomba Creek and South Branch Rush River, only samples collected during the same sampling period were used. For example, if a sample for a storm was missed at the upstream Chetomba Creek site (05314510), then the sample collected for that storm at the downstream Chetomba Creek site (05314518) was not used in the comparison.

Sediment samples collected during storms were used as an assessment of temporal variability in SSC. Ten separate sets of storm samples were collected during water years 2006-08. During these storms, individual sample bottles from the automated sampler were analyzed individually for SSC.

Eleven quality-assurance samples, which consisted of field blanks and replicates, were collected and analyzed for nutrients. Field blanks are water samples prepared and tested to be free of nutrient concentrations that were processed through the sampling equipment. Three field blanks collected near sampling sites were used to evaluate potential sample contamination from sampling equipment, cleaning procedures, and the atmosphere. No detectable concentrations of nitrite plus nitrate, total nitrogen, or total phosphorus were measured in any of the field blank samples.

Eight replicate samples were collected sequentially with environmental samples. Replicate samples were used to determine the sample variability resulting from sample collection and laboratory analysis. Table 5 presents the analytical results of the analysis of nutrients in replicate samples and their associated environmental samples. The median relative percentage difference (RPD) in concentrations between the environmental samples and replicate samples for nitrite plus nitrate, total nitrogen, and total phosphorus was 1.0 percent.

\section{Physical Habitat Characterization}

Physical habitat was characterized during 2006 and 2007 at the three primary data-collection sites (05314510, 0531656290, and 05326189) at the time of biological collections following methods described in Fitzpatrick and others (1998). A stream reach equal to 20 times the mean wetted channel width was established at each site, and specific measurements were made at each of 11 transects along the reach. Measurements included stream width and depth; in-stream habitat cover (macrophyte, woody debris, and overhanging vegetation); bottom substrate composition; and geomorphologic characterization. Riparian land-use characteristics were determined for each site using GIS analyses of aerial photography (Johnson and Zelt, 2005). The analysis area for each stream reach was defined by an area extending to $50 \mathrm{~m}$ perpendicular to the stream reach. Land use within the stream-reach analysis area was delineated using on-screen digitizing of digital orthophotograph quarter quadrangles (2003-04 color orthophotographs from the Farm Service Agency).

\section{Collection and Analysis of Benthic Algal Samples}

Benthic algal samples were collected for this study according to methods described by Moulton and others (2002). Benthic algae (periphyton) were collected once in 2006 and once in 2007 from a 150-m reach at each of the primary sites during late summer when streamflow typically is low. Benthic algae samples were collected from the upper 5- to 7-mm layer of sand substrate in five depositional areas of the reach. At each location, the lid of a Petri dish (47 $\mathrm{mm}$ in diameter) was pressed carefully into the substrate to avoid disturbing benthic algae. A spatula was placed under the Petri dish to enclose

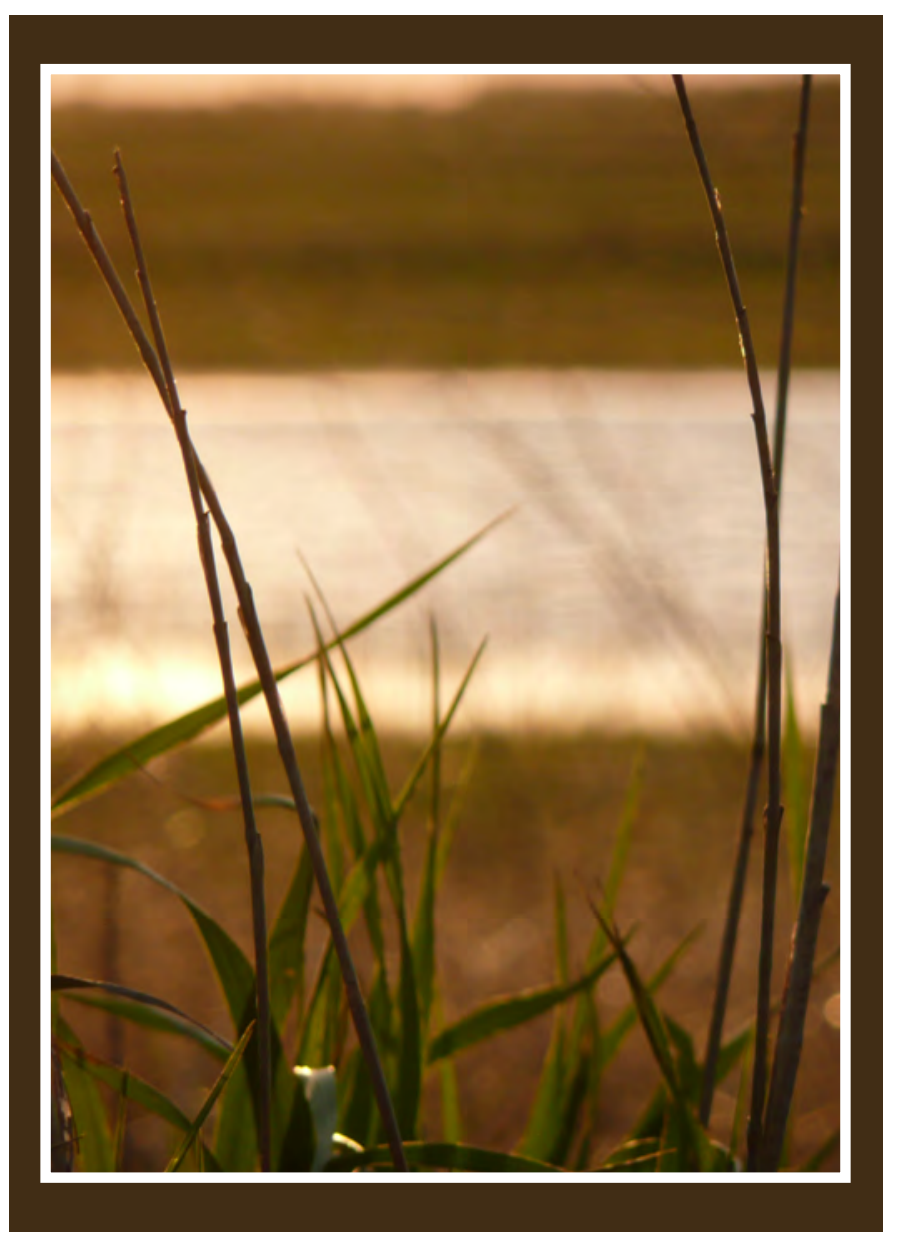


Table 5. Nutrient concentrations in environmental and associated replicate samples from three streams in the Minnesota River Basin, water years 2006-08.

[mg/L, milligrams per liter; RPD, relative percentage difference; E, environmental; R, replicate]

\begin{tabular}{|c|c|c|c|c|c|c|c|c|}
\hline $\begin{array}{l}\text { U.S. Geological } \\
\text { Survey site } \\
\text { number (fig. 1) }\end{array}$ & $\begin{array}{c}\text { Date (month/ } \\
\text { day/year) }\end{array}$ & $\begin{array}{l}\text { Type of } \\
\text { sample }\end{array}$ & $\begin{array}{l}\text { Nitrite plus } \\
\text { nitrate } \\
\text { concentration } \\
\text { (mg/L) }\end{array}$ & RPD' & $\begin{array}{c}\text { Total nitrogen } \\
\text { concentration } \\
\text { (mg/L) }\end{array}$ & RPD & $\begin{array}{c}\text { Total phosphorus } \\
\text { concentration } \\
\text { (mg/L) }\end{array}$ & RPD \\
\hline \multirow[t]{4}{*}{05314510} & $10 / 27 / 2005$ & $\mathrm{E}$ & 18.4 & 0 & 19.1 & 1.6 & .005 & 0 \\
\hline & $10 / 27 / 2005$ & $\mathrm{R}$ & 18.4 & & 18.8 & & .005 & \\
\hline & $6 / 5 / 2008$ & $\mathrm{E}$ & 12.4 & 0 & 13.7 & .7 & .12 & 26.7 \\
\hline & $6 / 5 / 2008$ & $\mathrm{R}$ & 12.4 & & 13.8 & & .152 & \\
\hline \multirow[t]{2}{*}{05314518} & $7 / 23 / 2008$ & $\mathrm{E}$ & 0.16 & 12.5 & 1.69 & 7.7 & .222 & 1.8 \\
\hline & $7 / 23 / 2008$ & $\mathrm{R}$ & 0.14 & & 1.56 & & .218 & \\
\hline \multirow[t]{4}{*}{0531656290} & $10 / 26 / 2005$ & $\mathrm{E}$ & 11.7 & 0.9 & 12.7 & .8 & .025 & 4.0 \\
\hline & $10 / 26 / 2005$ & $\mathrm{R}$ & 11.8 & & 12.6 & & .026 & \\
\hline & $6 / 25 / 2008$ & $\mathrm{E}$ & 10.1 & 1.0 & 10.6 & 0 & .132 & .8 \\
\hline & $6 / 25 / 2008$ & $\mathrm{R}$ & 10 & & 10.6 & & .133 & \\
\hline \multirow[t]{2}{*}{05326180} & $6 / 5 / 2008$ & $\mathrm{E}$ & 19 & 1.1 & 22.6 & 1.8 & .77 & 1.3 \\
\hline & $6 / 5 / 2008$ & $\mathrm{R}$ & 19.2 & & 22.2 & & .76 & \\
\hline \multirow[t]{4}{*}{05326189} & $5 / 29 / 2007$ & $\mathrm{E}$ & 17.4 & 0 & 18.2 & 2.7 & .076 & 2.6 \\
\hline & $5 / 29 / 2007$ & $\mathrm{R}$ & 17.4 & & 18.7 & & .074 & \\
\hline & $6 / 14 / 2007$ & $\mathrm{E}$ & 15.3 & 0 & 16.9 & 1.8 & .145 & 2.1 \\
\hline & $6 / 14 / 2007$ & $\mathrm{R}$ & 15.3 & & 16.6 & & .142 & \\
\hline
\end{tabular}

${ }^{1}$ Relative percentage difference is calculated with the absolute value of the equation [(Environmental concentration-Replicate concentration)/Environmental concentration] x 100 .

the collection. The five samples were composited into one container with rinse water. Samples were processed to remove benthic algae from substrate by a series of elutriations. The elutriation process was used to separate the benthic algae from the fine- or coarse-grained material. The algal-water mixture was poured into a clean 1-liter (L) plastic container, taking care not to introduce sand into the clean container. Several subsamples were removed for processing. Samples were homogenized, then split for chlorophyll- $a$, ash-free dry mass, and for taxonomic identification. A subsample of 3-5 mL was removed for chlorophyll- $a$ (Moulton and others, 2002) and ash-free dry mass determination, frozen on dry ice, and sent to NWQL for analysis (Britton and Greeson, 1987).
The remaining sample was preserved with 4-percent buffered formalin for taxonomic identification. Algae (diatoms and soft algae) were identified to the lowest possible taxon by the Academy of Natural Sciences, Patrick Center for Environmental Research (Charles and others, 2002). Approximately 600 algal cells were counted from each sample, and results were tabulated as the abundance (cells per square centimeter) and biovolume (cubic micrometers per square centimeter) for each taxon. Taxon richness was reported as the number of taxa encountered during a count of about 600 algal cells (Charles and others, 2002). The relative abundance (percentage cell density) of each taxon was calculated for each sample. 


\section{Collection and Analysis of Invertebrate Samples}

Stream invertebrate communities were collected using modified methods from Moulton and others (2002). Samples were collected within a $150-\mathrm{m}$ reach from sandy bottom substrates using a core sampler. The core sampler was depressed approximately $10 \mathrm{~cm}$ into the stream-bottom sediment, and a spatula was used to enclose the collection prior to placing it in a compositing container. Samples were collected from five locations within each sampling reach. Tap water was used to separate the invertebrates from bottom substrate through successive rinsing and sieving. All sieves had mesh sizes of 500 microns $(\mu \mathrm{m})$. The sieved samples were preserved with 10-percent formalin prior to transfer to the laboratory. During 2006, samples were sent to the Minnesota Department of Natural Resources Laboratory in Saint Paul for identification and enumeration. During 2007, samples were sent to the USGS NWQL for identification and enumeration. Benthic macroinvertebrates were quantified based on a fixed-count approach that targeted a minimum count of 300 organisms. Organisms were sorted from randomly selected 5.1 by $5.1 \mathrm{~cm}$ parts of a gridded subsampling frame. The sorted remnant from each sample was resorted by a second individual for at least 10 percent of the original sort time (Moulton and others, 2000). Invertebrate data were analyzed using the USGS Invertebrate Data Analyses System (IDAS; Cuffney, 2003).

\section{Collection and Analysis of Fish}

Fish were collected during August 2006 and 2007 from a $150-\mathrm{m}$ reach at each stream by electrofishing equipment (pulsed DC, direct current) and conducted according to protocols established for the USGS National Water-Quality Assessment Program (Moulton and others, 2002). Briefly, backpack electrofishing gear was used to make two collection passes within the reach. Sampling time was recorded to normalize catch per unit of effort.

Index of biotic integrity (IBI) scores were used to measure fish community response and community health. Biotic integrity commonly is defined as "the ability to support and maintain a balanced, integrated, and adaptive community of organisms having a species composition, diversity, and functional organization comparable to those of natural habitats within a region" (Karr and Dudley, 1981). The IBI as originally created by Karr (1981) consists of 12 measures or metrics. Each of these metrics has a range of sensitivity to differing types of environmental degradation. The IBI values for this report were calculated following Bailey and others (1993) using 8 of the 12 metrics related to the composition and structure of the fish community (table 6). The sum of the metric scores is the IBI score, which ranges from 12 to 60 (larger numbers indicate better aquatic resource quality than lower numbers). Physical habitat was characterized at each stream location at the time of fish collections following Fitzpatrick and others (1998).

\section{Longitudinal Synoptic Survey of Biomass Accumulation}

The objective in measuring the rate of plant biomass accumulation is to estimate primary productivity, otherwise known as the rate at which inorganic carbon is incorporated or "fixed" in living tissue as organic carbon. In stream ecosystems, estimation of the total amount of carbon fixed by plants requires estimates of production by sestonic (minute living organisms and particles of nonliving matter that float in water and contribute to turbidity) and periphytic (microorganisms that coat rocks, plants, and other surfaces on the water bottom) algae as well other vascular and nonvascular aquatic plants. The complexity of making all of these measurements simultaneously in a flowing stream highlights the appeal of the reach metabolism approach pioneered by Odum $(1956,1957)$. However, estimates of individual components of primary production provide additional insights into the structure and function of aquatic ecosystems.

One component of stream ecosystem primary production was investigated in Chetomba Creek through the use of nutrient-diffusing substrate (NDS) periphytometers. These devices measure the growth of attached algae known as periphyton while providing an experimental supply of bioavailable nutrients. The nutrients can be added singly or in combination to test for single nutrient limitation or colimitation. NDS periphytometers can be used further to estimate benthic algae community growth rates along a single limiting-nutrient enrichment gradient (for example, Wise and others, 2009).

As part of the investigation into how retired lands affect nutrient assimilative capacity and general water quality, liquidliquid NDS periphytometers were deployed in Chetomba Creek in August 2008. Periphytometers were deployed at four locations in Chetomba Creek (see enlarged area, fig. 1): (1) approximately $1.6 \mathrm{~km}$ (site 05314517 , downstream from County Road 60 road crossing), (2) 4.8 km (site 05314516 , upstream from County Road 55 road crossing), (3) 6.4 $\mathrm{km}$ (site 05314515 , upstream from unnamed section road crossing), and (4) $14.5 \mathrm{~km}$ (site 05314510) upstream from the confluence of Chetomba Creek with Spring Creek (fig. 1). The upstream deployment in Chetomba Creek near Renville (site 05314510 , fig. 1) was immediately downstream from this primary USGS site on Chetomba Creek. All deployments lasted for 2 weeks from August 12 through August 25, 2008.

In all cases, periphytometers were modified from a design developed by Matlock and others (1998) to conform to narrow streams with shallow depths. These micro-NDS periphytometers have reduced reservoir volume and reduced exposed filter area (fig. $5 A$ ). As with the original design by Matlock and others (1998), nutrients diffuse from a liquid media reservoir through a nylon $0.45-\mu \mathrm{m}$ barrier filter and out onto a glass-fiber filter (see McFarland and others, 2004). Each filter unit is covered with neutral fiberglass screen to prevent fish and large invertebrate grazers from feeding on the surface of the filters. Treatments are positioned within the 
Table 6. Description of individual metrics that compose the index of biotic integrity.

\begin{tabular}{|c|c|}
\hline Metric & Description \\
\hline $\begin{array}{l}\text { Number of fish species } \\
\text { collected }\end{array}$ & $\begin{array}{l}\text { The number of fish in the community is associated with the complexity of the environment. } \\
\text { Stream degradation in the form of habitat, hydrologic, or chemical alterations will result in } \\
\text { a simplification of the community and a decrease in the number of species (Karr and others, } \\
\text { 1986; Bailey and others, 1993). }\end{array}$ \\
\hline $\begin{array}{l}\text { Percentage of fish classified as } \\
\text { tolerant }\end{array}$ & $\begin{array}{l}\text { Tolerant species can thrive in streams with degraded conditions. Common carp, white sucker, } \\
\text { black bullhead, fathead minnow, and creek chub were classified as tolerant by Bailey and } \\
\text { others (1993). }\end{array}$ \\
\hline Number of darter species & $\begin{array}{l}\text { Darters belong to the perch family and are habitat specialists, meaning they have strict } \\
\text { environmental requirements including coarse gravel found in stream riffles. This metric is } \\
\text { considered to be sensitive to habitat changes and chemical changes (Karr and others, 1986; } \\
\text { Bailey and others, 1993). }\end{array}$ \\
\hline Number of minnow species & $\begin{array}{l}\text { Minnows are an important and diverse component of the fish community in most warm or } \\
\text { cool water streams throughout the Midwest. Because minnows exhibit a wide range of food } \\
\text { and habitat preferences, this group of fish is sensitive to a wide range of environmental } \\
\text { degradation. }\end{array}$ \\
\hline Number of intolerant species & $\begin{array}{l}\text { The presence of intolerant fish species in a stream is an indication of good resource quality. } \\
\text { Intolerant fish species are often the first species to disappear following a disturbance. }\end{array}$ \\
\hline $\begin{array}{l}\text { Proportion of benthic } \\
\text { insectivores }\end{array}$ & $\begin{array}{l}\text { Fish with specialized feeding behaviors like those who consume insects from bottom substrate } \\
\text { in a certain habitat will not be able to respond to degraded conditions as quickly as } \\
\text { omnivores. }\end{array}$ \\
\hline Proportion of omnivores & $\begin{array}{l}\text { Omnivores are able to consume a wide variety of food sources, so they are able to tolerate } \\
\text { environmental degradation because they are flexible eaters. }\end{array}$ \\
\hline $\begin{array}{l}\text { Catch per unit effort (on all } \\
\text { fish except tolerant ones) } \\
\text { per hour }\end{array}$ & $\begin{array}{l}\text { The assumption for this metric is that a site with little degradation will yield more fish in an } \\
\text { hour than a site with degradation. }\end{array}$ \\
\hline
\end{tabular}

racks with controls and single-nutrient treatments upstream from the nitrogen-plus-phosphorus treatment. The glass-fiber filter acts as the artificial substrate, and the filter is colonized by facultative and obligate periphyton propagules suspended in the river or stream. Filters are held perpendicular to the substrate to prevent settling of sediment onto the filters and parallel to the major axis of flow as in the original design. However, unlike the Matlock design, the micro-NDS periphytometers were deployed at the bottom of the water column directly on the substrate and anchored into place using two torpedo weights. The stream was shallow and thus light limitation was not likely to occur (fig. 5B).

Three nutrient treatments plus a control were used at each periphytometer deployment site in Chetomba Creek. Nutrient treatments consisted of the addition of nitrogen $(\mathrm{N})$, phosphorus $(\mathrm{P})$, or $\mathrm{N}$ and $\mathrm{P}$ in combination. All nutrient additions were at a single level with five or more replicate samples per treatment. Nutrient media additions of 3 milligrams per liter $(\mathrm{mg} / \mathrm{L})$ nitrate $\left(\mathrm{NO}_{3}-\mathrm{N}\right)$ and $1 \mathrm{mg} / \mathrm{L}$ phosphate $\left(\mathrm{PO}_{4}-\mathrm{P}\right)$ provided 350 micromolar nitrogen $(\mu \mathrm{M} \mathrm{N})$ and 100 micromolar phosphorus ( $\mu \mathrm{M} \mathrm{P})$ solutions in the NDS media reservoirs. These concentrations were meant to provide a nutrient-sufficient supply - that is, a nonlimiting supply of a nutrient.

After the periphytometers were deployed, nutrients were delivered to the filter substrate by diffusion over a 14-day in-stream incubation. After 14 days, filters were retrieved and frozen until analysis. Algal biomass production was measured as chlorophyll- $a$ accumulation on the glass-fiber filter substrates over the 14-day period. Algal growth responses were analyzed for significant nutrient limitation using twofactor analysis of variance that tested for treatment and site effects (Sokal and Rohlf, 1995). Nutrient treatments were compared to the ambient controls to test for nutrient limitation. 


\section{Water-Quality Characteristics of Three Streams in the Minnesota River Basin}

Characteristics of streamflow, physical properties, and concentrations of nutrients, suspended sediment, and chlorophyll- $a$ for three streams - Chetomba Creek, West Fork Beaver Creek, and South Branch Rush River-in the Minnesota River Basin are described in this section of the report. The effects of streamflow on SSC also are described.

\section{Streamflow}

The drainage areas of Chetomba Creek, West Fork Beaver Creek, and South Branch Rush River account for about 2 percent of the Minnesota River drainage basin. Many other tributaries contribute surface water and are a possible source of nutrients, sediment, and other chemicals. Streamflow in the Chetomba Creek, West Fork Beaver Creek, and South Branch Rush River subbasins varied during water years 2006-08 (fig. 6). The 2008 water year was a low-flow year in the Chetomba Creek and West Fork Beaver Creek subbasins compared to water years 2006 and 2007 (table 7).

The hydrologic conditions during the years of sample collection affect water quality and biological communities. For Chetomba Creek, West Fork Beaver Creek, and South
Branch Rush River, substantial rainfall affected streamflow. Stage measurements during runoff indicate that Chetomba Creek, West Fork Beaver Creek, and South Branch Rush River respond rapidly to rainfall.

Streamflow in Chetomba Creek near Renville ranged from 0 to 38.5 cubic meters per second $\left(\mathrm{m}^{3} / \mathrm{s}\right)$ during water years 2005-08. Streamflow in West Fork Beaver Creek ranged from 0 to $12.5 \mathrm{~m}^{3} / \mathrm{s}$ during water years $2005-08$. Streamflow at South Branch Rush River near Norseland ranged from 0 to $16.5 \mathrm{~m}^{3} / \mathrm{s}$ during water years $2006-08$. Mean annual streamflow was larger in water year 2006 than in water year 2007 for Chetomba Creek, West Fork Beaver Creek, and South Branch Rush River (table 7). The maximum instantaneous peak flow for Chetomba Creek near Renville and South Branch Rush River near Norseland occurred in water year 2006, and the maximum peak flow for West Fork Beaver Creek occurred in water year 2007 (table 7). Streamflow in water year 2008 was smaller than in water years 2006 and 2007 for Chetomba Creek and West Fork Beaver Creek. However, temporal streamflow patterns for South Branch Rush were different from those for the other study sites, having a larger mean annual flow in water year 2008 than in water years 2006 and 2007.

Water years 2007 and 2008 were historically dry years regionally. Zero flow occurred during many days in water years 2007 and 2008 for Chetomba Creek and South Branch Rush River. For the 10-year period of record (1999-2008) at
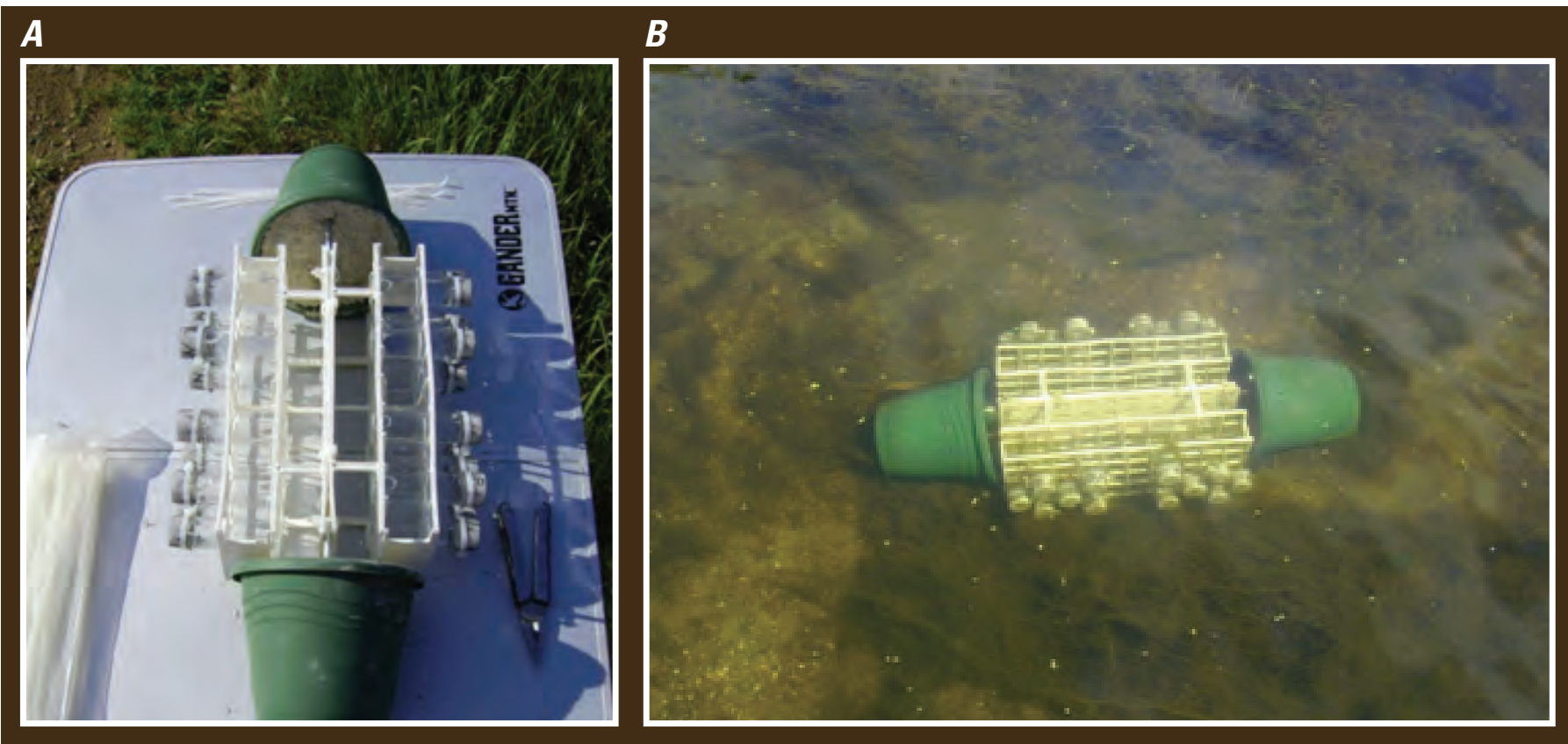

Figure 5. A micro nutrient-diffusing substrate periphytometer. $A$, prior to deployment. $B$, deployed in Chetomba Creek in August 2008. 


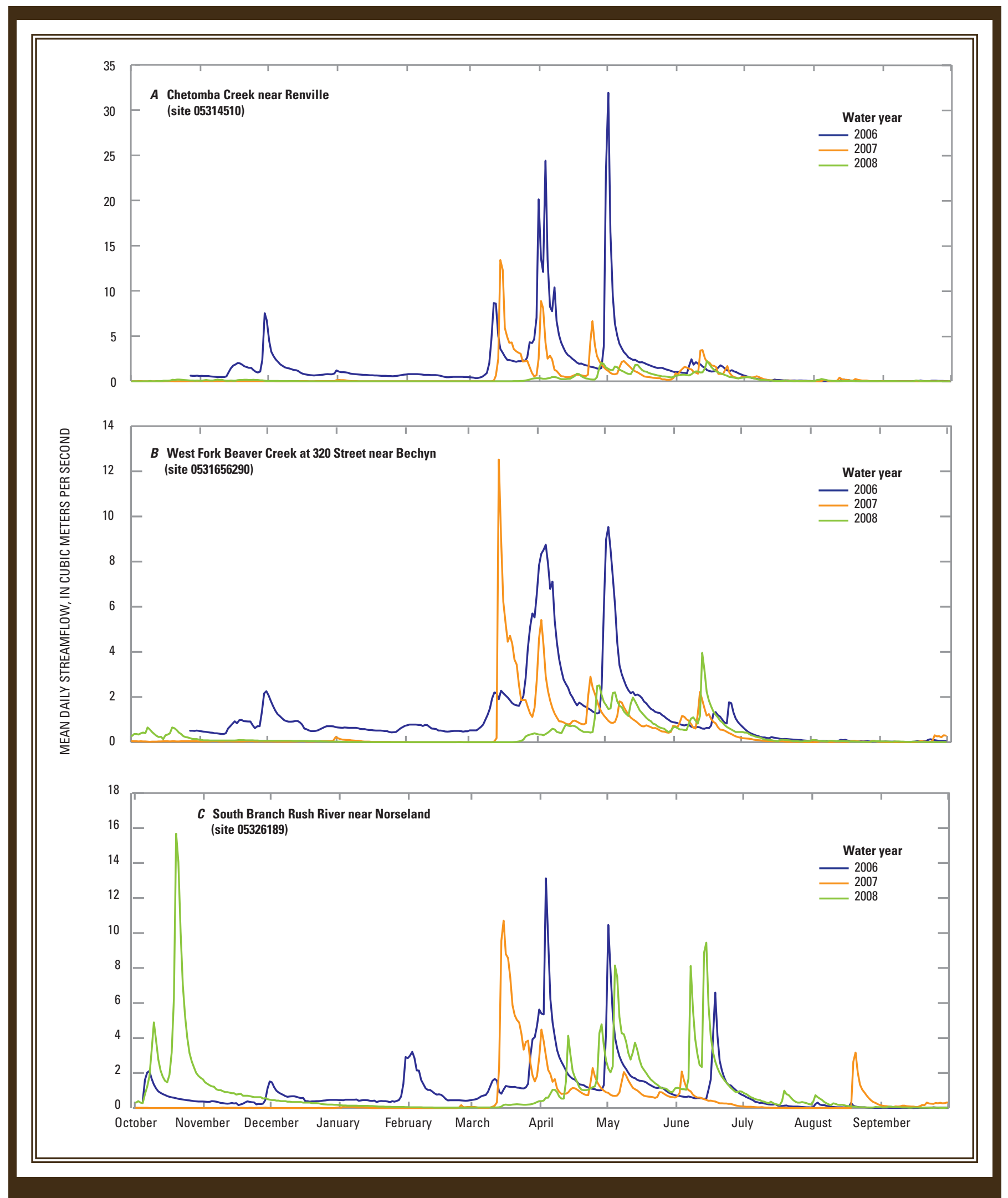

Figure 6. Mean daily streamflow. A, Chetomba Creek near Renville. $B$, West Fork Beaver Creek near Bechyn. C, South Branch Rush River near Norseland, water years 2006-08. Location of sampling sites shown in figure 1. 


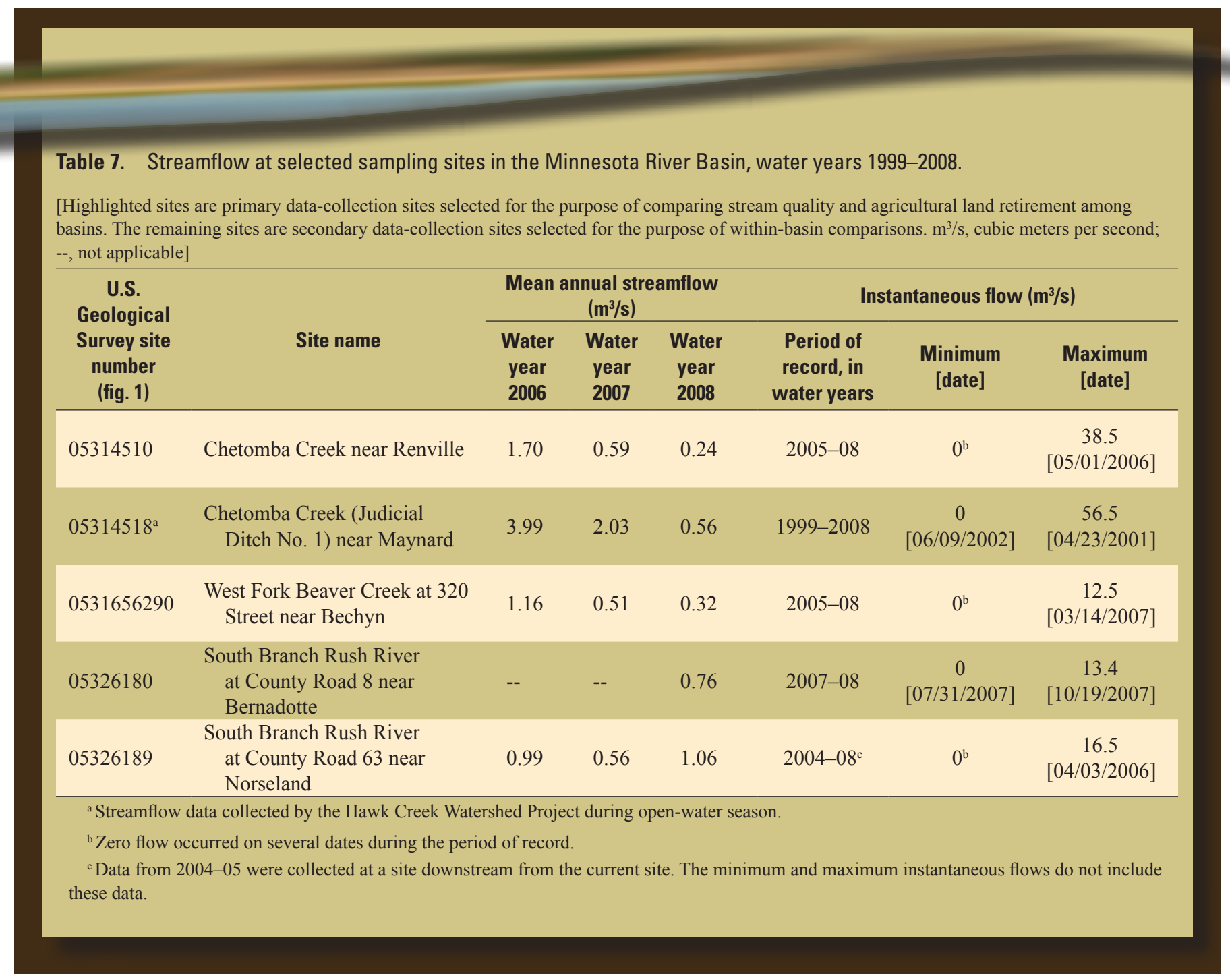

Chetomba Creek near Maynard (site 05314518), the mean annual streamflow was $2.59 \mathrm{~m}^{3} / \mathrm{s}\left(91.3 \mathrm{ft}^{3} / \mathrm{s}\right)$, which is greater than the mean annual flows at this site during water years 2007 and 2008. Although the period of record is shorter at the other sites compared to site 05314518 , water years 2007 and 2008 likely were low-flow years compared to historical flows at those sites as well (Chetomba Creek, West Fork Beaver Creek, and South Branch Rush River). Because of the effect of streamflow on water quality, concentrations of nutrients and sediment in this report may not be representative of historical conditions.

\section{Physical Properties}

The seasonal variability in stream quality is evident in the continuous physical property data collected with in-stream water-quality monitors at the five sampling sites (figs. 7-11). Specific conductance, $\mathrm{pH}$, temperature, turbidity, and dissolved oxygen were measured continuously at the five sampling sites during the growing seasons (generally May through September), except for the monitor at West Fork Beaver Creek, which was removed during the 2008 growing season, and during periods when the monitors became fouled or went out of calibration. The physical property data, performance of the water-quality monitors, and the quality of the data are presented and described in the Annual Data Reports of the USGS found on the Web at http://mn.water. usgs.gov/publications/pubswdr.html.

Specific conductance at the five sampling sites (figs. 7-11) tends to vary with streamflow (fig. 6), usually decreasing during high streamflow and increasing during low streamflow. Specific conductance generally decreased throughout the growing season.

Substantial seasonal variability in $\mathrm{pH}$ is difficult to determine with the scale of the graphs (figs. 7-11). Diurnal variability in $\mathrm{pH}$ (and other measures of stream quality) can be attributed to several factors, including photosynthesis, 
reaeration, respiration (Guasch and others, 1998), and plant uptake (Hessen and others, 1997).

Temperature predictably increases during the summer months with occasional decreases occurring during storms. For example, at Chetomba Creek near Renville during 2006 (fig. $7 A$ ), temperature decreased quickly around June 13 during a relatively small increase in streamflow (fig. $6 \mathrm{~A}$ ) that corresponded to a storm. In addition to seasonal and stormdriven fluctuations, temperature also varied diurnally at all sites (figs. 7-11). Temperature is a concern for these streams because aquatic organisms are adapted to a certain temperature range (Allan, 1995). When temperatures fluctuate outside these ranges, growth, reproduction, and other functions of these aquatic organisms may be affected (Allan, 1995).

Turbidity is an event-driven property of water, which typically increases with increases in streamflow, but also increases with other stream disturbances such as animal activity. Seasonal variability in turbidity is not evident in figures 7-11. West Fork Beaver Creek had larger ambient turbidity but fewer event-driven increases in turbidity than the other streams.

Dissolved oxygen is another property measured continuously by the water-quality monitors that has substantial diurnal variability. The Chetomba Creek near Maynard site (fig. 8) stands out among the sites for its small dissolved oxygen fluctuations. This site has a drop structure where water is dropped to a lower level, dissipating energy and preventing the erosive effect of the water before it reaches the waterquality monitor location. Although this physical structure aerates the water, which leads to more stable dissolved oxygen concentrations, this pattern may not be evident because of missing data (fig. 8). Decreases in dissolved oxygen concentrations tend to occur late in the summer (for example, Aug. 14-29, 2008, fig. 7C), when temperatures are higher and water levels and streamflow are lower.

\section{Nutrient, Suspended-Sediment, and Chlorophyll-a Concentrations}

Nutrient, suspended-sediment, and chlorophyll- $a$ data collected for this study are available from http://nwis. waterdata.usgs.gov/mn/nwis/qwdata. For water years $2006-$ 08 , mean nitrite plus nitrate concentrations were largest in the South Branch Rush River and smaller in Chetomba Creek and West Fork Beaver Creek (table 8). Payne (1994) reported that during 1989-92 nitrate concentrations were as large as 28 $\mathrm{mg} / \mathrm{L}$ in the Rush River downstream from the South Branch Rush River near Norseland site (05326189, fig. 1). Although nitrite plus nitrate concentrations during water years 2006 and 2007 were substantially smaller than those measured in the Rush River in 1994, samples analyzed in water year

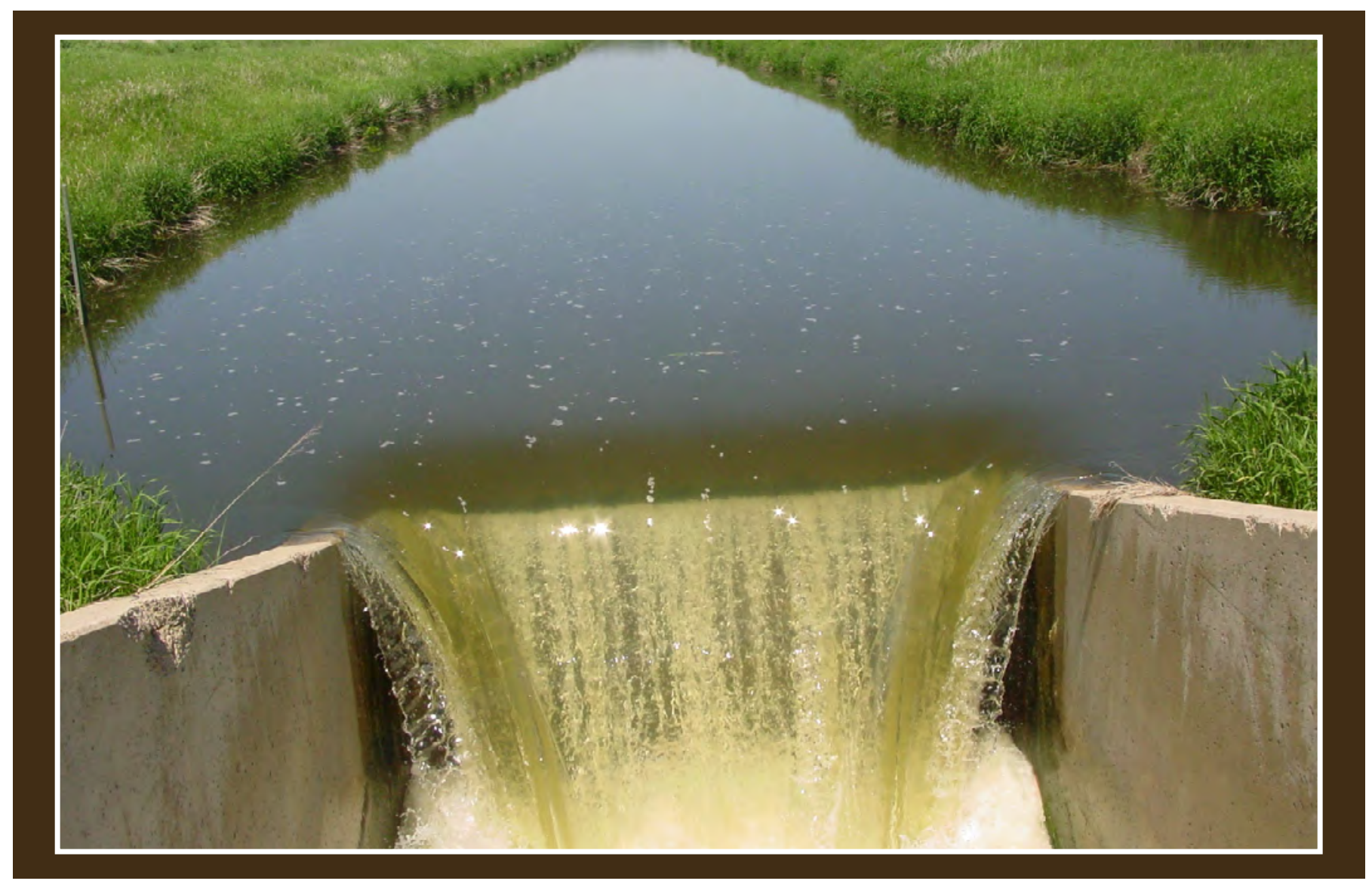




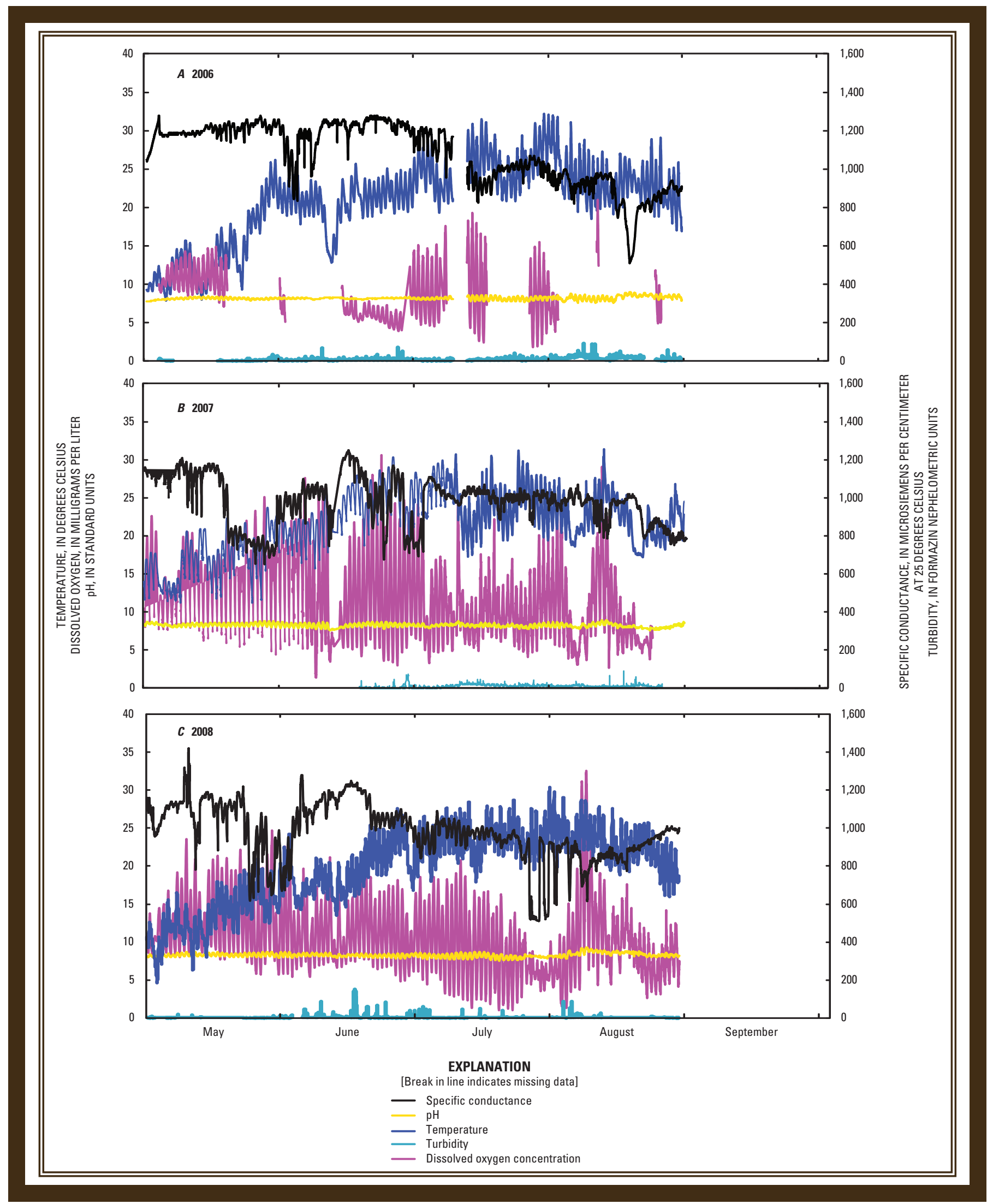

Figure 7. Continuous water-quality measurements of physical properties during growing season for Chetomba Creek near Renville (site 05314510, fig. 1). A, 2006. B, 2007. C, 2008. 


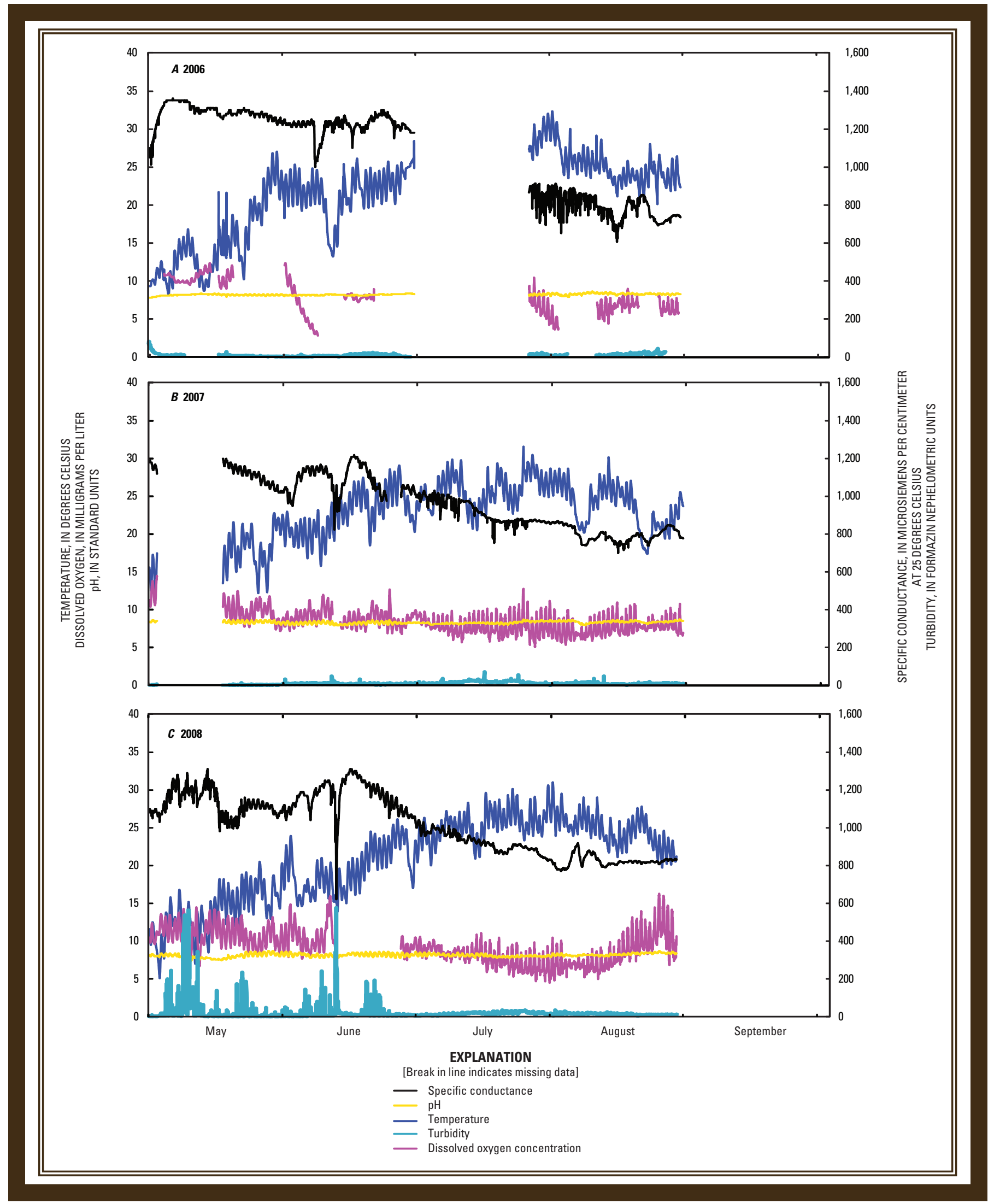

Figure 8. Continuous water-quality measurements of physical properties during growing season for Chetomba Creek near Maynard (site 05314518, fig. 1). A, 2006. B, 2007. C, 2008. 


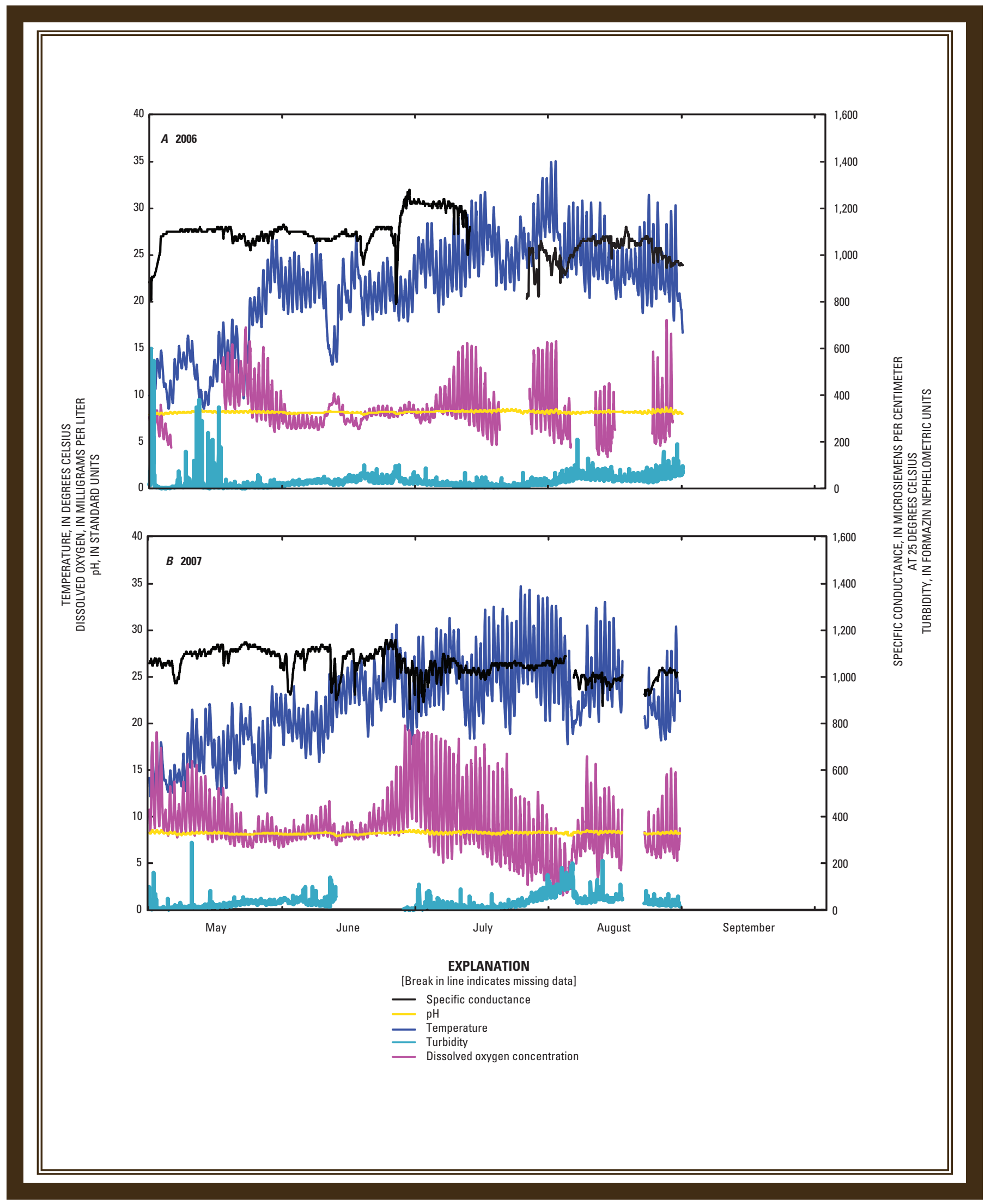

Figure 9. Continuous water-quality measurements of physical properties during growing season for West Fork Beaver Creek near Bechyn (site 0531656290, fig. 1). A, 2006. B, 2007. 


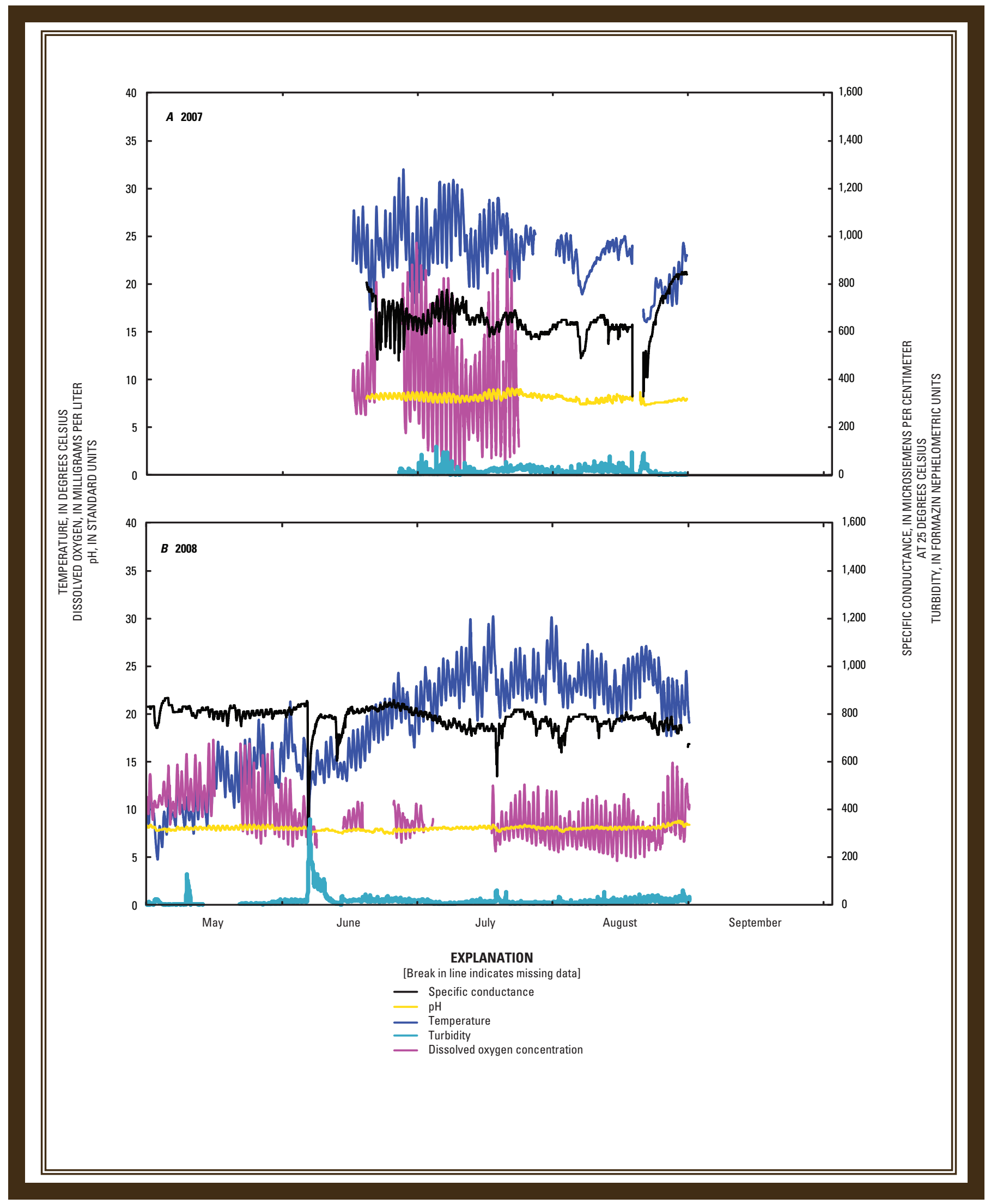

Figure 10. Continuous water-quality measurements of physical properties during growing season for South Branch Rush River near Bernadotte (site 05326180, fig. 1). A, 2007. B, 2008. 


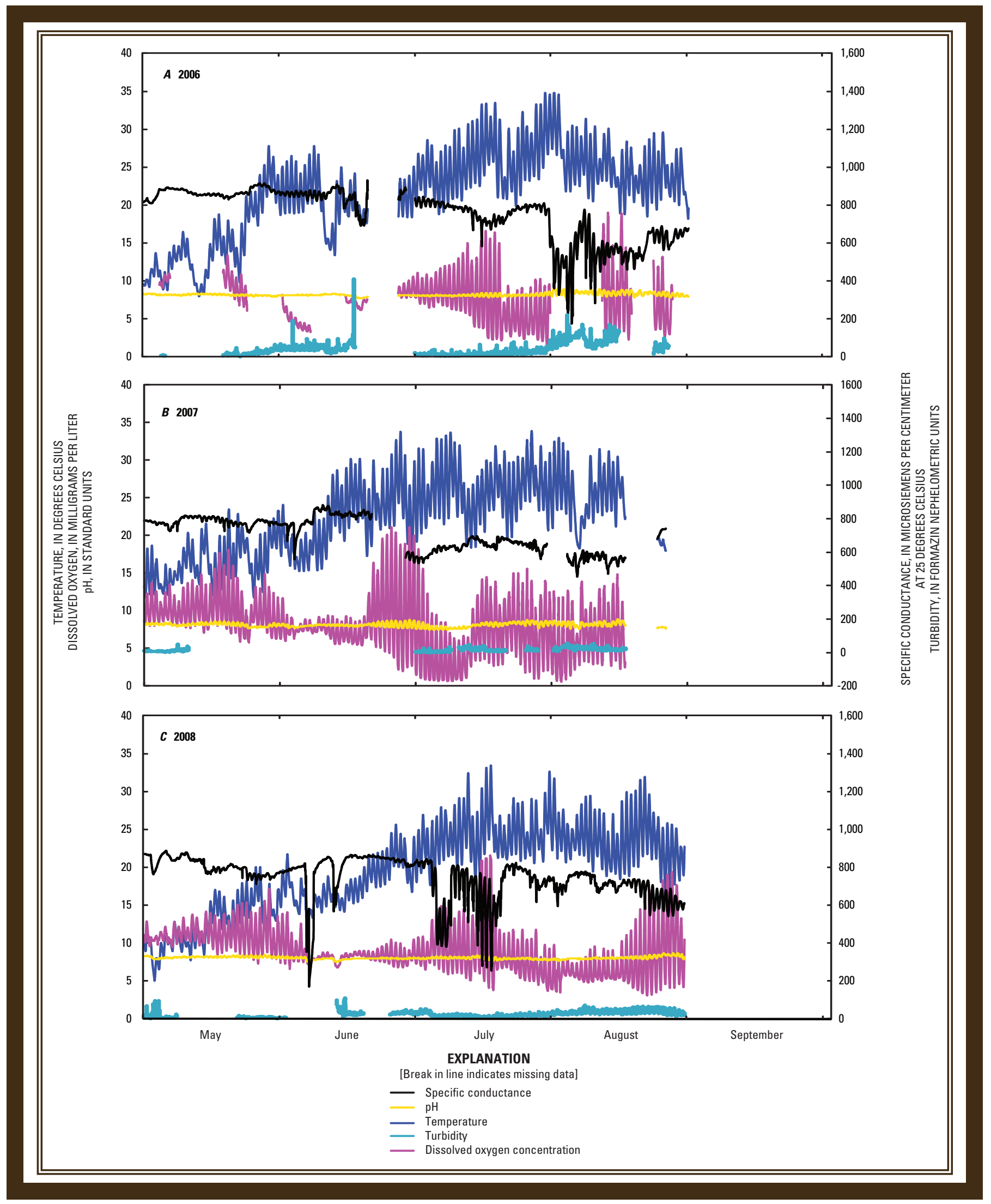

Figure 11. Continuous water-quality measurements of physical properties during growing season for South Branch Rush River near Norseland (site 05326189, fig. 1). A, 2006. B, 2007. C, 2008. 
Table 8. Mean nutrient, suspended-sediment, and seston chlorophyll-a concentrations in water from selected sampling sites in the Minnesota River Basin, water years 2006-08.

[All nutrient and suspended-sediment concentrations are in milligrams per liter; seston chlorophyll- $a$ concentrations are in micrograms per liter; low-flow samples were those collected below the 25 th percentile of flow; high-flow samples are defined as those collected at the 25 th percentile of flow, which was based on a streamflow duration curve for the period of record at each site; numbers in parentheses indicate number of samples; --, not applicable]

\begin{tabular}{lccc}
\hline \multicolumn{1}{c}{ Constituent } & Mean concentrations (number of samples) & All samples \\
\hline & Low-flow samples & High-flow samples & $9.4(20)$ \\
\hline Nitrite plus nitrate & $6.2(13)$ & $15.2(7)$ & $10.6(20)$ \\
Total nitrogen & $7.3(13)$ & $16.6(7)$ & $.164(20)$ \\
Total phosphorus & $.163(13)$ & $.166(7)$ & $.077(20)$ \\
Orthophosphorus & $.074(13)$ & $.085(7)$ & $17.5(10)$ \\
Chlorophyll- $a$ & $20.4(8)$ & $5.9(2)$ & $72(59)$
\end{tabular}

Chetomba Creek near Maynard (Judicial Ditch No. 1; site 05314518, fig. 1)

\begin{tabular}{|c|c|c|c|}
\hline Nitrite plus nitrate & $3.8(8)$ & $11.05(3)$ & $5.75(11)$ \\
\hline Total nitrogen & $4.7(8)$ & $12.52(3)$ & $6.28(11)$ \\
\hline Total phosphorus & $.120(8)$ & $.090(4)$ & $.110(12)$ \\
\hline Orthophosphorus & $.062(8)$ & $.052(4)$ & $.059(12)$ \\
\hline Chlorophyll- $a$ & $6.5(6)$ & $16.2(3)$ & $9.7(9)$ \\
\hline Suspended sediment ${ }^{1}$ & $47(4)$ & $52(2)$ & $49(6)$ \\
\hline \multicolumn{4}{|c|}{ West Fork Beaver Creek at 320 Street near Bechyn (site 0531656290, fig. 1) } \\
\hline Nitrite plus nitrate & $4.3(12)$ & $12.2(7)$ & $7.2(19)$ \\
\hline Total nitrogen & $4.7(12)$ & $13.5(7)$ & $7.9(19)$ \\
\hline Total phosphorus & $.237(12)$ & $.297(7)$ & .259 (19) \\
\hline Orthophosphorus & $.132(12)$ & $.120(7)$ & $.128(19)$ \\
\hline Chlorophyll- $a$ & $17.0(8)$ & $5.1(1)$ & $15.7(9)$ \\
\hline Suspended sediment ${ }^{1}$ & $100(9)$ & $402(28)$ & $329(37)$ \\
\hline
\end{tabular}


Table 8. Mean nutrient, suspended-sediment, and seston chlorophyll-a concentrations in water from selected sampling sites in the Minnesota River Basin, water years 2006-08-Continued.

[All nutrient and suspended-sediment concentrations are in milligrams per liter; seston chlorophyll- $a$ concentrations are in micrograms per liter; low-flow samples were those collected below the 25th percentile of flow; high-flow samples are defined as those collected at the 25th percentile of flow, which was based on a streamflow duration curve for the period of record at each site; numbers in parentheses indicate number of samples; --, not applicable]

Mean concentrations (number of samples)

\begin{tabular}{lccc}
\hline \multicolumn{1}{c}{ Constituent } & Low-flow samples & High-flow samples & All samples \\
\hline & South Branch Rush River at County Road 8 near Bernadotte (site 05326180, fig. 1) \\
\hline Nitrite plus nitrate & $10.8(10)$ & $16.0(4)$ & $11.9(13)$ \\
Total nitrogen & $12.5(10)$ & $17.9(4)$ & $13.6(13)$ \\
Total phosphorus & $.235(10)$ & $.314(4)$ & $.269(13)$ \\
Orthophosphorus & $.093(10)$ & $.164(4)$ & $.121(13)$ \\
Chlorophyll- $a$ & $7.8(5)$ & $9.7(1)$ & $8.1(6)$ \\
Suspended sediment ${ }^{1}$ & $122(19)$ & $453(35)$ & $337(54)$ \\
\hline
\end{tabular}

South Branch Rush River at County Road 63 near Norseland (site 05326189, fig. 1)

\begin{tabular}{lccc}
\hline Nitrite plus nitrate & $10.0(16)$ & $19.2(11)$ & $13.8(27)$ \\
Total nitrogen & $11.3(16)$ & $20.4(11)$ & $15.0(27)$ \\
Total phosphorus & $.174(16)$ & $.187(11)$ & $.180(27)$ \\
Orthophosphorus & $.079(16)$ & $5.9(2)$ & $.073(27)$ \\
Chlorophyll- $a$ & $12.1(9)$ & $196(105)$ & $11.0(11)$ \\
Suspended sediment & 1 & $98(9)$ & $188(114)$
\end{tabular}

${ }^{1}$ Numerous suspended-sediment samples were collected during some storms. Because the sampling schedule for suspended sediment was substantially different among sites (more storm samples were collected at some sites than others), the suspended-sediment results were not be used for comparisons among basins. 
2008 were as large as those measured by Payne (1994) with a maximum nitrite plus nitrate concentration of $29.1 \mathrm{mg} / \mathrm{L}$.

Total nitrogen concentrations were largest, with a mean of 15.0 milligrams per liter (mg/L), in the South Branch Rush River near Norseland, the subbasin with little to no land retirement. Total nitrogen concentrations were smaller in Chetomba Creek near Renville (mean of $10.6 \mathrm{mg} / \mathrm{L}$ ) and West Fork Beaver Creek near Bechyn (mean of $7.9 \mathrm{mg} / \mathrm{L}$ ), which are subbasins with more riparian or upland land retirement. A water sample collected on June 13, 2006, from Chetomba Creek near Maynard had a nitrite plus nitrate concentration of $15.3 \mathrm{mg} / \mathrm{L}$ and a total nitrogen concentration of $3.27 \mathrm{mg} / \mathrm{L}$. Because total nitrogen includes nitrite plus nitrate, the total nitrogen concentration for this sample should have been equal to or larger than the nitrite plus nitrate concentration. For this reason, this sample was not included in the calculated means reported in table 8 .

Total phosphorus concentrations were smallest in water samples from Chetomba Creek near Maynard (Judicial Ditch No. 1, site 05314518, fig. 1) and largest in samples from the South Branch Rush River near Bernadotte (site 05326180, fig. 1). The mean total phosphorus concentration in samples from West Fork Beaver Creek (site 0531656290, fig. 1) was larger relative to mean concentrations in samples from the Chetomba Creek sites and the South Branch Rush near Norseland site (table 8). Total phosphorus concentrations were not related directly to differing percentages of land retirement, with mean concentrations at primary data-collection sites of $0.164 \mathrm{mg} / \mathrm{L}$ in the Chetomba Creek subbasin, $0.259 \mathrm{mg} / \mathrm{L}$ in the West Fork Beaver Creek subbasin, and $0.180 \mathrm{mg} / \mathrm{L}$ in the South Branch Rush River subbasin. In this study, both nitrogen and phosphorus concentrations were smallest in the subbasin with the largest percentage of retired land (Chetomba Creek). Nitrogen concentrations were largest in the subbasin with little or no land retirement (South Branch Rush River).

Mean chlorophyll- $a$ concentrations were largest in water from Chetomba Creek near Renville (site 05314510, fig. 1), followed by concentrations in samples from West Fork Beaver Creek (site 0531656290, fig. 1). Chlorophyll- $a$ was collected more often during low-flow than during high-flow conditions (table 8).

Mean nutrient, suspended-sediment, and chlorophyll- $a$ concentrations reported in table 8 were divided between low- and high-flow samples (high-flow samples are those collected at the 25th percentile of flow, as determined on the basis of sampling-site duration curves; the remainder are low-flow samples). For most constituents, the high-flow samples had larger mean concentrations; however, there were exceptions for orthophosphorus and chlorophyll- $a$. The smaller orthophosphorus concentrations during high flow may be due to a dilution effect. Mean chlorophyll- $a$ concentrations were smaller during high flow than during low flow for the three primary sampling sites (05314510, 0531656290, and 05326189, fig. 1). For these sites, high flows probably wash away the seston, leading to smaller chlorophyll- $a$ concentrations.
Major sources of nutrients include agricultural activities such as the seasonal application of synthetic fertilizers and the pasturing and confined feeding of livestock (Christensen and Pope, 1997). Seasonal variability in water quality was difficult to evaluate for nutrients because of the small number of samples collected across the range in seasons. However, differences between water years 2006, 2007, and 2008 were evaluated by comparing mean annual concentrations (table 9).

Mean annual concentrations of nitrite plus nitrate and total nitrogen decreased from water year 2006 to water year 2008 at the Chetomba Creek and West Fork Beaver sites (table 9). This decrease corresponds to a decrease in mean annual streamflow (table 7). Annual differences in nitrite plus nitrate and total nitrogen concentrations at the South Branch Rush River sites are not as easily explained; however, the mean annual total nitrogen concentrations were smallest during water year 2007, the water year with the smallest streamflow.

Mean annual total phosphorus concentrations generally were largest in water year 2007. These larger concentrations in water year 2007 cannot be explained by annual streamflow (table 7) and possibly are due to other factors, such as differences in fertilizer application from year to year, the contribution of groundwater, or the timing of fertilizer applications and storms.

SSC in the Minnesota River commonly is large compared to concentrations in other Minnesota streams (Tornes, 1986). Tornes (1986) suggests that because the Minnesota River Basin is relatively flat, most sediment is transported after storms erode fine-grained soils exposed by intensive cultivation. Intensively cultivated clay and loess contribute large quantities of suspended sediment. The west-to-east precipitation gradient could cause the eastern part of the basin to have more runoff-producing storms, therefore resulting in larger sediment loads irrespective of land-use activity (Payne, 1994).

Spatial variability in SSC among sampling sites is similar to the variability in total phosphorus concentrations. The South Branch Rush River near Bernadotte (site 05326180, fig. 1) had the largest SSCs, followed by West Fork Beaver Creek, South Branch Rush River near Norseland, and the Chetomba Creek sites (table 8). Sediment and total phosphorus commonly are related. This relation occurs because organic forms of phosphorus are mostly present in the particulate form (Christensen and others, 2006), and therefore, most of the phosphorus carried by the stream is in the solid phase.

\section{Effects of Streamflow on Suspended-Sediment Concentrations}

Several storms occurred in the study area during water years 2006-08. During the storms, the automated samplers collected as many as 24 sample bottles. Many of these samples were composited and analyzed, and the mean SSCs of these composited samples are reported in table 8. During other storms, samples were analyzed individually, and the 
Table 9. Mean annual nutrient concentrations in water from selected sampling sites in the Minnesota River Basin, water years 2006-08.

[All nutrient concentrations are in milligrams per liter; number in parentheses indicates number of samples; --, no samples collected]

Mean annual concentration (number of samples)

\begin{tabular}{|c|c|c|c|}
\hline Constituent & Water year 2006 & Water year 2007 & Water year 2008 \\
\hline \multicolumn{4}{|c|}{ Chetomba Creek near Renville (site 05314510 , fig. 1) } \\
\hline Nitrite plus nitrate & $12.7(8)$ & $7.7(5)$ & $6.8(7)$ \\
\hline Total nitrogen & $13.6(8)$ & $9.3(5)$ & $8.1(7)$ \\
\hline Total phosphorus & $.114(8)$ & $.227(5)$ & $.176(7)$ \\
\hline Orthophosphorus & $.051(8)$ & $.111(5)$ & $.085(7)$ \\
\hline \multicolumn{4}{|c|}{ Chetomba Creek near Maynard (Judicial Ditch No. 1; site 05314518, fig. 1) } \\
\hline Nitrite plus nitrate & $11.3(3)$ & $4.0(4)$ & $3.3(4)$ \\
\hline Total nitrogen & $12.2(3)$ & $4.9(4)$ & $4.7(4)$ \\
\hline Total phosphorus & $.041(4)$ & $.164(4)$ & $.125(4)$ \\
\hline Orthophosphorus & $.022(4)$ & $.102(4)$ & $.052(4)$ \\
\hline \multicolumn{4}{|c|}{ West Fork Beaver Creek at 320 Street near Bechyn (site 0531656290, fig. 1) } \\
\hline Nitrite plus nitrate & $10.3(9)$ & $4.7(7)$ & $3.7(3)$ \\
\hline Total nitrogen & $10.3(9)$ & $6.2(7)$ & $4.8(3)$ \\
\hline Total phosphorus & $.234(9)$ & $.282(7)$ & $.282(3)$ \\
\hline Orthophosphorus & $.086(9)$ & $.151(7)$ & $.198(3)$ \\
\hline
\end{tabular}

South Branch Rush River at County Road 8 near Bernadotte (site 05326180, fig. 1)

\begin{tabular}{lccr} 
Nitrite plus nitrate & - & $8.0(5)$ & $14.3(8)$ \\
Total nitrogen & -- & $10.0(5)$ & $15.9(8)$ \\
Total phosphorus & -- & $.302(5)$ & $.248(8)$ \\
Orthophosphorus & -- & $.140(5)$ & $.110(8)$ \\
\hline
\end{tabular}

South Branch Rush River at County Road 63 near Norseland (site 05326189, fig. 1)

\begin{tabular}{lccr} 
Nitrite plus nitrate & $17.9(8)$ & $9.9(10)$ & $14.4(9)$ \\
Total nitrogen & $18.4(8)$ & $11.3(10)$ & $16.1(9)$ \\
Total phosphorus & $.128(8)$ & $.180(10)$ & $.224(9)$ \\
Orthophosphorus & $.037(8)$ & $.090(10)$ & $.098(9)$ \\
\hline
\end{tabular}


results were compared to streamflow (fig. 12) in an effort to characterize the change in SSC during the rise and fall in streamflow. Precipitation gages were not available; therefore, increases in streamflow were used as a substitute for the onset of rainfall.

Ten sets of storm samples were collected during water years 2006-08 (fig. 12). The storm size (streamflow increase) and suspended-sediment response varied. Following most of the larger storms, the SSCs initially were large and gradually decreased as streamflow decreased (for example, South Branch Rush River near Bernadotte from June 5 to 9, 2008, fig. 12). However, this is not always a linear relation. In fact, the relation commonly is characterized as hysteresis, which is described by Evans and Davies (1998) as SSC at a given streamflow on the rising limb of the hydrograph that differs from that at the same streamflow on the falling limb of the hydrograph.

The response of SSC in streams to flow conditions commonly is a function of energy (Asselman, 1999). This means sediment that has been stored at low flow is transported under larger streamflow conditions. However, mixing and routing of water and sediment from different sources (Asselman, 1999, 2000) also plays a role in sediment response. The lag time between peak SSCs and the peak streamflow among sites and storms may be affected by antecedent moisture conditions (Walling and Foster, 1975). When streamflow has been large preceding a storm, readily available suspended sediment may have been exhausted or reduced by previous storms. The SSC then may decrease rapidly at the onset of a new storm in response to the dilute nature of storm runoff, and the peak in SSCs will occur at the same time or very shortly after the peak streamflow.

Nistor and Church (2005) give several examples of patterns of streamflow and SSC relations. The lag time between peak SSC and peak streamflow shown for the larger storms sampled in this study (fig. 12) supports the idea of depletion of sediment from runoff during the storm (Church and Gilbert, 1975; Walling and Webb, 1981) or the increased portion of base flow during the recession limb of the hydrograph (Walling, 1974, 1978; Wood, 1977). Payne (1994) also identified this pattern of the peak SSC occurring before the peak streamflow for several Minnesota River tributaries. Payne (1994) explains that this pattern also may be due in part to artificial drainage, including tile drains. According to Payne (1994), as streamflow from a storm decreases, a greater portion of the flow is supplied by shallow, subsurface drainage carried by tile drains and ditches. Water from tile drains contains virtually no suspended sediment.

Small storms show no clear relation between SSC and streamflow, which perhaps is an indication that SSC peaks are not associated with flow and that sediment is generated by an apparently random (Olive and Rieger, 1985) or unmeasured process. An example is Chetomba Creek near Renville during two storms in May 2008 (fig. 12) where the relation between streamflow and SSC appears to be random but perhaps is caused by the occasional sediment input of a small ditch just upstream from the sampling site.

Samples from only one storm (May 29-June 1, 2008) were collected at more than one site. This was a relatively small storm with streamflow increases of about $0.17-0.23 \mathrm{~m}^{3} / \mathrm{s}$ $\left(6-8 \mathrm{ft}^{3} / \mathrm{s}\right)$ at the Chetomba Creek near Renville site and the South Branch Rush River sites (fig. 12). The response of SSCs during this storm was similar at each of these sites.

\section{Biological Characteristics of Three Streams in the Minnesota River Basin}

Characteristics of physical habitats and biological communities for three streams - Chetomba Creek (site 05314510), West Fork Beaver Creek (site 0531656290), and South Branch Rush River (site 05326189) — in the Minnesota River Basin are described in this section of the report. The characteristics of biological communities include benthic algae, benthic invertebrates, and fish.

\section{Physical Habitat Characteristics}

Physical habitat characteristics varied among streams and among years (table 10). Stream-reach volume and habitat composition changed between water years 2006 and 2007 because of flow conditions. Stream widths and depths generally were greater in water year 2006 than in water year 2007, resulting in less habitat volume in water year 2007. Chetomba Creek had the largest overall reach volume during both years. The dominant types of in-stream cover for Chetomba Creek and South Branch Rush River were macrophyte/macroalgal cover and overhanging vegetation. West Fork Beaver Creek had little or no macrophyte/ macroalgal cover; rather the in-stream cover consisted of overhanging vegetation and woody debris. Bottom substrate at the Chetomba Creek site (05314510) and the South Branch Rush River site (05326189) was primarily gravel. At the West Fork Beaver Creek site (0531656290), the bottom substrate tended toward finer silt and clay. Riparian characteristics also varied among streams. The percentage of woody vegetation was largest at the West Fork Beaver Creek site (table 10). Overall, all three stream reaches had very open canopies with very little shading; however, the West Fork Beaver Creek site had some shading from the surrounding woody vegetation cover (table 10).

\section{Biological Community Characteristics}

Metrics of biological communities are important components of stream-quality assessments because individual organisms respond to physical habitat, hydrologic, and chemical alterations in predictable patterns, whereas community measurements tend to be on a more robust scale. 
The combination of physical, chemical, and biological measures provides an integrated assessment of resource quality. Biological communities form in response to chemical and physical environments and intraspecies interactions. Benthic algae form the base of the aquatic food chain and provide food resources for invertebrates and fish. Benthic algae have life cycles ranging from days to weeks and may respond rapidly to changes in dissolved nutrients, light, and temperature. Excessive amounts of nutrients in streams can produce nuisance growth of algae. This is commonly referred to as eutrophication. Excessive algal growth can cause organic enrichment through rapid algal cell growth and decay resulting in decreases in dissolved oxygen. Aquatic invertebrates are important elements of resource assessments because they tend to live in or on stream sediment, have life cycles of months to years, and integrate the effects over approximately 1 year (Barbour and others, 1999). Aquatic invertebrates are a very diverse group of organisms with a wide variety of sizes, habitat requirements, life histories, and sensitivities to resource degradation. Fish are used extensively for measuring waterresource quality. Fish are longer lived (years to decades) than algae or invertebrates. The combination of algal, invertebrate, and fish characterizations provides information that covers a variety of conditions and over differing time periods.

\section{Benthic Algal Community Characteristics}

A total of 134 benthic algal taxa were collected among all sites and during all sampling periods (app. 1). A majority of the taxa collected were diatoms (118), followed by green algae (7), blue-green algae (6), and Euglenoids (3). Most of the algal taxa from the three streams in this study were classified as moderately tolerant (Bahls, 1993) of degraded conditions.

Algal taxa richness (number of taxa collected at a site) was least for the South Branch Rush River site (05326189) and greatest for the West Fork Beaver Creek site (0531656290; table 11). Similar to findings from Allan (1995), diatoms composed the majority of benthic algal taxa (more than 80 percent) at all sites. Green and blue-green algae were the next most abundant algal groups on the basis of taxa richness.

Algal biovolume and cell density are indicators of algal standing crop. Biovolume is a measure of the algal cell volume per unit area. This is essentially the thickness of the algal cells on the substrate. Total algal biovolume was largest at the Chetomba Creek site, followed by the West Fork Beaver Creek site and the South Branch Rush River site (table 11). The larger volume of algae at the Chetomba Creek site indicates that conditions at this site are ideal for algal growth (long residence time, little riparian shading, stable substrate, and sufficient dissolved nutrient concentrations). Green algae were the dominant algal group at the Chetomba Creek site in terms of the percentage of total algal biovolume (fig. $13 \mathrm{~A}$ ), whereas diatoms were dominant at the other two sites. Density is the number of algal cells per unit area. Density measures commonly highlight smaller cells such as blue-green algae that are large in number but have small cell volume. Blue-green algae had the largest density at the Chetomba Creek site, whereas diatoms were dominant at the other sites. The difference between water years in the composition of the community likely was due to differences in hydrologic conditions, nutrient and light availability, and temperature.

Streams with degraded conditions can have a dominance of a few types of organisms that are able to thrive under degraded conditions (tolerant organisms). All three streams were dominated by very few taxa. Three taxa composed more than 50 percent of the total biovolume at each site (fig. 14). The percentage of algal biovolume composed by the three most dominant taxa was largest at the Chetomba Creek site (fig. 14). The algal biovolume at the Chetomba Creek site was dominated by Cladophora sp. during August 2006 and July 2007. These filamentous green algae become abundant when nitrogen and phosphorus concentrations are relatively large (Stevenson and others, 1996). The South Branch Rush River and West Fork Beaver Creek sites also had a few taxa that were dominant. Three diatom species, Cyclotella meneghiniana, Synedra sp., and Nitzchia amphibia composed most of the biovolume at the South Branch Rush River site during August 2006. During July 2007, three diatomsSynedra ulna, Melosira varians, and Cocconeis placentulawere dominant at the South Branch Rush River site. Spirogyra sp. and Synedra sp. composed most of the biovolume at the West Fork Beaver Creek site during August 2006, and the diatom Surirella gracilis composed most of the biovolume in July 2007.

Benthic algae are primary producers and are important in nutrient cycling in streams. Benthic algae transform inorganic forms of nitrogen, phosphorus, and carbon into organic forms (Stevenson and others, 1996). In hydrologically stable nutrient-enriched streams, benthic algae can grow rapidly because they respond rapidly to chemical conditions. Benthic algae are limited by light availability, nutrient resources, grazing by other aquatic organisms, water temperature, and residence time. In this study, nutrient concentrations in all three streams indicate eutrophic conditions (high level of plant nutrients) (Dodds and others, 1998). However, algal biovolume and benthic chlorophyll- $a$ concentrations differed among sites and water years, which indicates that other factors may be controlling algal growth. Although all three streams had fairly stable hydrologic conditions prior to sampling, the West Fork Beaver Creek site had more wooded vegetation in the riparian area, a more closed canopy, larger SSCs, and larger turbidity values that may limit light availability and algal growth. A substantial proportion of benthic algae in all three streams are those found in mesoeutrophic (moderate level of plant nutrients) to eutrophic conditions. The Chetomba Creek site had the largest algal biovolume and density, and the algal community was dominated by very few taxa that are indicative of enriched conditions. 

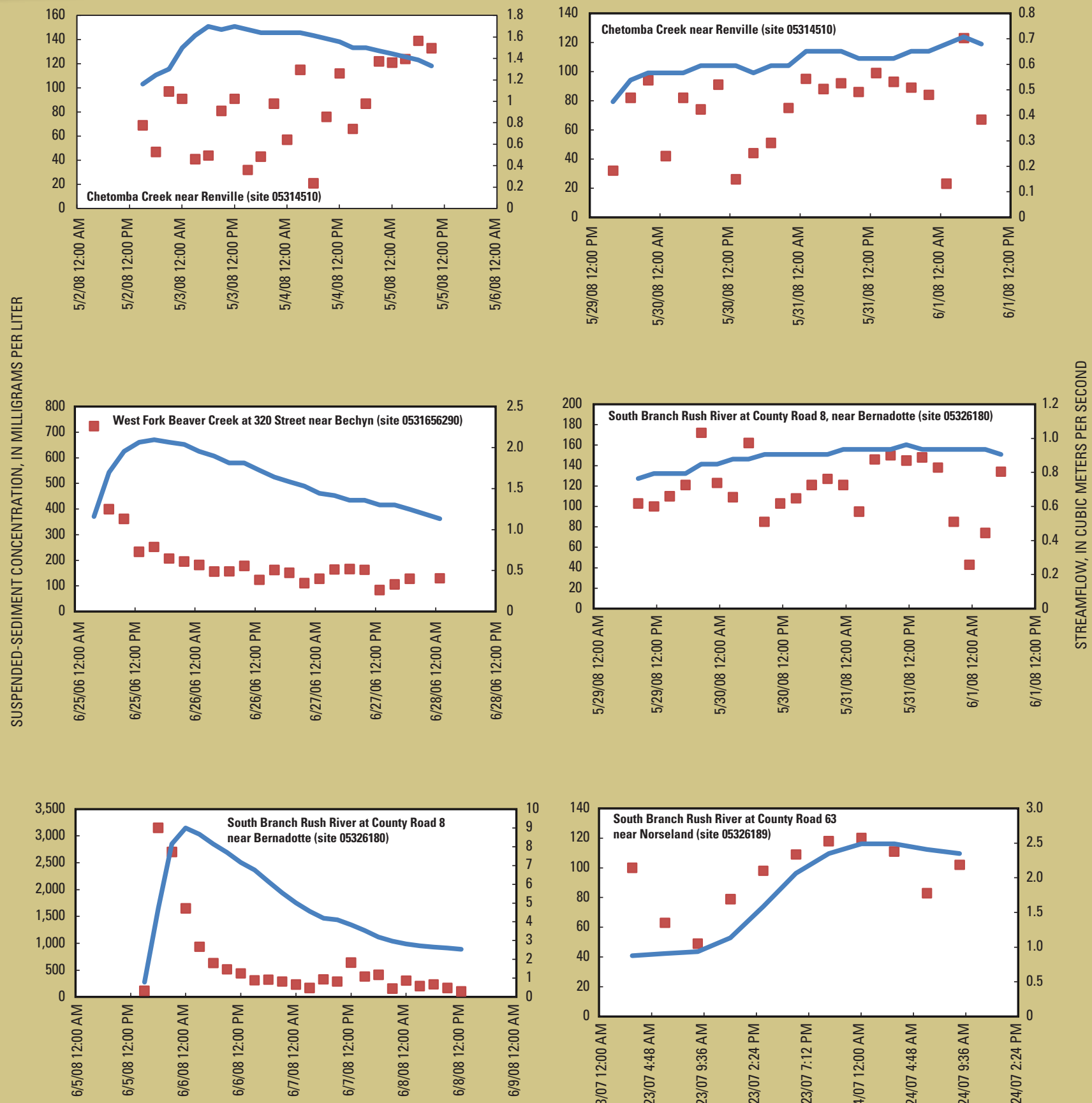

Figure 12. Suspended-sediment concentrations compared to streamflow during storms at Chetomba Creek near Renville, West Fork Beaver Creek near Bechyn, South Branch Rush River near Bernadotte, and South Branch Rush River near Norseland, water years 2006-08. Location of sampling sites shown in figure 1. 

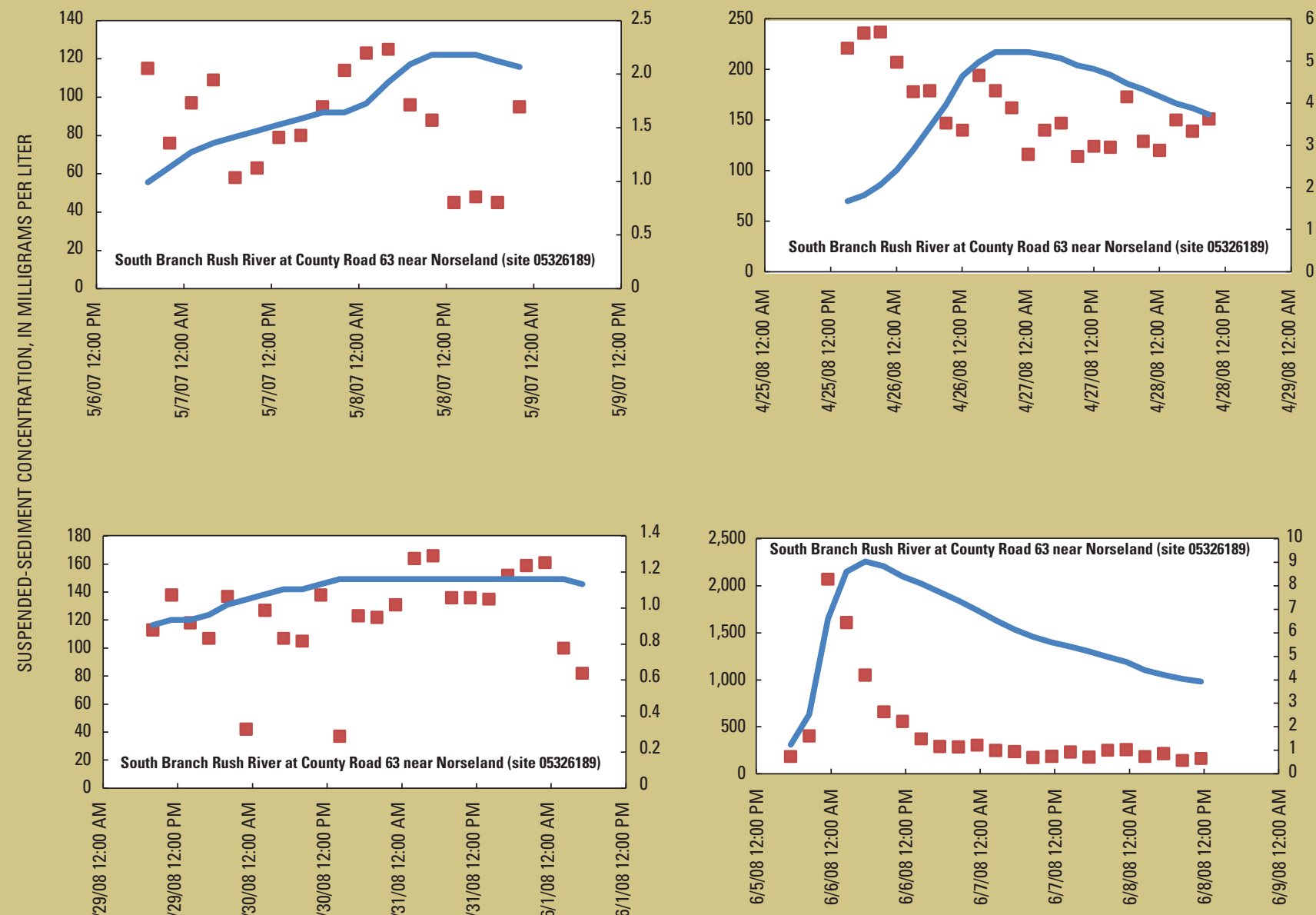

EXPLANATION

- Streamflow

- Suspended-sediment concentration 
Table 10. Summary of physical habitat characteristics for streams at selected sampling sites in the Minnesota River Basin, August 2006 and July 2007.

$\left[\mathrm{m}\right.$, meters; $\mathrm{m}^{2}$, square meters; $\mathrm{m}^{3}$, cubic meters; $\mathrm{mm}$, millimeters; >, greater than; --, no data]

\begin{tabular}{|c|c|c|c|c|c|c|}
\hline \multirow{2}{*}{ Physical habitat characteristic } & \multicolumn{2}{|c|}{$\begin{array}{c}\text { Chetomba Creek } \\
\text { (site 05314510, fig. 1) }\end{array}$} & \multicolumn{2}{|c|}{$\begin{array}{l}\text { West Fork Beaver Creek } \\
\text { (site 0531656290, fig. 1) }\end{array}$} & \multicolumn{2}{|c|}{$\begin{array}{l}\text { South Branch Rush River } \\
\text { (site } 05326189 \text {, fig. 1) }\end{array}$} \\
\hline & 2006 & 2007 & 2006 & 2007 & 2006 & 2007 \\
\hline \multicolumn{7}{|c|}{ Physical characteristics } \\
\hline Reach length (m) & 150 & 150 & 150 & 150 & 150 & 150 \\
\hline Average wetted channel width (m) & 6.2 & 4.9 & 4.6 & 3.9 & 4.2 & 2.6 \\
\hline Average depth (m) & .17 & .14 & .15 & .16 & .10 & .08 \\
\hline Average velocity (m) & .04 & .03 & .06 & .02 & .08 & .008 \\
\hline Reach volume $\left(\mathrm{m}^{3}\right)$ & 158 & 103 & 104 & 94 & 63 & 31 \\
\hline Reach area $\left(\mathrm{m}^{2}\right)$ & 930 & 735 & 690 & 585 & 630 & 390 \\
\hline \multicolumn{7}{|c|}{ In-stream habitat cover characteristics } \\
\hline Macrophyte/macroalgal cover (percent) ${ }^{1}$ & 98 & 44 & 1.8 & 0 & 22 & 22 \\
\hline Overhanging vegetation (percent) & 75 & 22 & 16 & 15 & 38 & 18 \\
\hline Woody debris (percent) & 0 & 0 & 26 & 6 & 0 & 0 \\
\hline
\end{tabular}

Bottom substrate composition characteristics

\begin{tabular}{|c|c|c|c|c|c|c|}
\hline Silt, clay, and organic detritus (percent) ${ }^{1}$ & 0 & 2 & 70 & 89 & 0 & 0 \\
\hline Sand $>0.062-2 \mathrm{~mm}$ (percent) & 0 & 18 & 15 & 4 & 13 & 60 \\
\hline Fine gravel $>2-16 \mathrm{~mm}$ (percent) & 77 & 55 & 6 & 7 & 78 & 40 \\
\hline Coarse gravel $>16-32 \mathrm{~mm}$ (percent) & 23 & 24 & 6 & 0 & 9 & 0 \\
\hline
\end{tabular}

Riparian characteristics ${ }^{2}$

\begin{tabular}{|c|c|c|c|c|c|c|}
\hline Percentage of woody vegetation & -- & 0 & -- & 21 & -- & 0 \\
\hline Canopy openness ${ }^{3}$ & -- & 147 & -- & 85 & -- & 135 \\
\hline
\end{tabular}

${ }^{1}$ Percentage of measurements for which selected cover was present (out of 55 measurements).

${ }^{2}$ Percentage of land cover within 50 meters perpendicular to the stream reach.

${ }^{3}$ Measurement of open canopy angle. Zero degrees represents a completely closed canopy; 180 degrees represents a completely open canopy with no channel shading. 
Table 11. Summary of algal community characteristics at selected stream sampling sites in the Minnesota River Basin, August 2006 and July 2007.

$\left[\mu \mathrm{m}^{3} / \mathrm{cm}^{2}\right.$, cubic micrometers per square centimeter; $\mathrm{mg} / \mathrm{m}^{2}$, milligrams per square meter; cells $/ \mathrm{cm}^{2}$, cells per square centimeter]

\begin{tabular}{|c|c|c|c|c|c|c|}
\hline \multirow{2}{*}{$\begin{array}{l}\text { Physical habitat } \\
\text { characteristic }\end{array}$} & \multicolumn{2}{|c|}{$\begin{array}{c}\text { Chetomba Creek } \\
\text { (site 05314510, fig. 1) }\end{array}$} & \multicolumn{2}{|c|}{$\begin{array}{l}\text { West Fork Beaver Creek } \\
\text { (site 0531656290, fig. 1) }\end{array}$} & \multicolumn{2}{|c|}{$\begin{array}{c}\text { South Branch Rush River } \\
\text { (site } 05326189 \text {, fig. 1) }\end{array}$} \\
\hline & 2006 & 2007 & 2006 & 2007 & 2006 & 2007 \\
\hline Taxa richness & 57 & 59 & 68 & 68 & 51 & 55 \\
\hline Total biovolume $\left(\mu \mathrm{m}^{3} / \mathrm{cm}^{2}\right)$ & $1.42 \times 10^{11}$ & $2.82 \times 10^{10}$ & $6.37 \times 10^{9}$ & $1.56 \times 10^{10}$ & $2.75 \times 10^{9}$ & $1.68 \times 10^{9}$ \\
\hline Chlorophyll $a\left(\mathrm{mg} / \mathrm{m}^{2}\right)$ & 25.0 & 172.0 & 32.0 & 25.9 & 78.3 & 40.0 \\
\hline $\begin{array}{l}\text { Total algal density (number } \\
\text { of cells } / \mathrm{cm}^{2} \text { ) }\end{array}$ & $1.07 \times 10^{7}$ & $7.56 \times 10^{6}$ & $4.16 \times 10^{6}$ & $3.49 \times 10^{6}$ & $2.76 \times 10^{6}$ & $1.95 \times 10^{6}$ \\
\hline $\begin{array}{l}\text { Percentage of algal taxa } \\
\text { classified as blue-green } \\
\text { algae }\end{array}$ & 5.3 & 6.8 & 4.4 & 2.9 & 0 & 3.6 \\
\hline $\begin{array}{l}\text { Percentage of algal taxa } \\
\text { classified as green algae }\end{array}$ & 8.8 & 3.4 & 1.5 & 0 & 0 & 5.4 \\
\hline $\begin{array}{l}\text { Percentage of algal taxa } \\
\text { classified as diatoms }\end{array}$ & 84.2 & 89.8 & 92.6 & 95.6 & 98.0 & 90.9 \\
\hline $\begin{array}{l}\text { Percentage of algal } \\
\text { biovolume classified as } \\
\text { blue-green algae }\end{array}$ & .2 & 1.4 & 1.3 & .1 & 0 & .2 \\
\hline $\begin{array}{l}\text { Percentage of algal } \\
\text { biovolume classified as } \\
\text { green algae }\end{array}$ & 98.3 & 87.4 & 46.5 & 0 & 0 & .3 \\
\hline $\begin{array}{l}\text { Percentage of algal } \\
\text { biovolume classified as } \\
\text { diatoms }\end{array}$ & 1.6 & 11.2 & 52.0 & 99.3 & 99.4 & 99.5 \\
\hline $\begin{array}{l}\text { Percentage of algal density } \\
\text { classified as blue-green } \\
\text { algae }\end{array}$ & 61.6 & 50.0 & 34.3 & 8 & 0 & 5.2 \\
\hline $\begin{array}{l}\text { Percentage of algal density } \\
\text { classified as green algae }\end{array}$ & 3.5 & 1.0 & .9 & 0 & 0 & 6.1 \\
\hline $\begin{array}{l}\text { Percentage of algal density } \\
\text { classified as diatoms }\end{array}$ & 34.9 & 50.0 & 64.6 & 90.8 & 99.3 & 88.7 \\
\hline
\end{tabular}




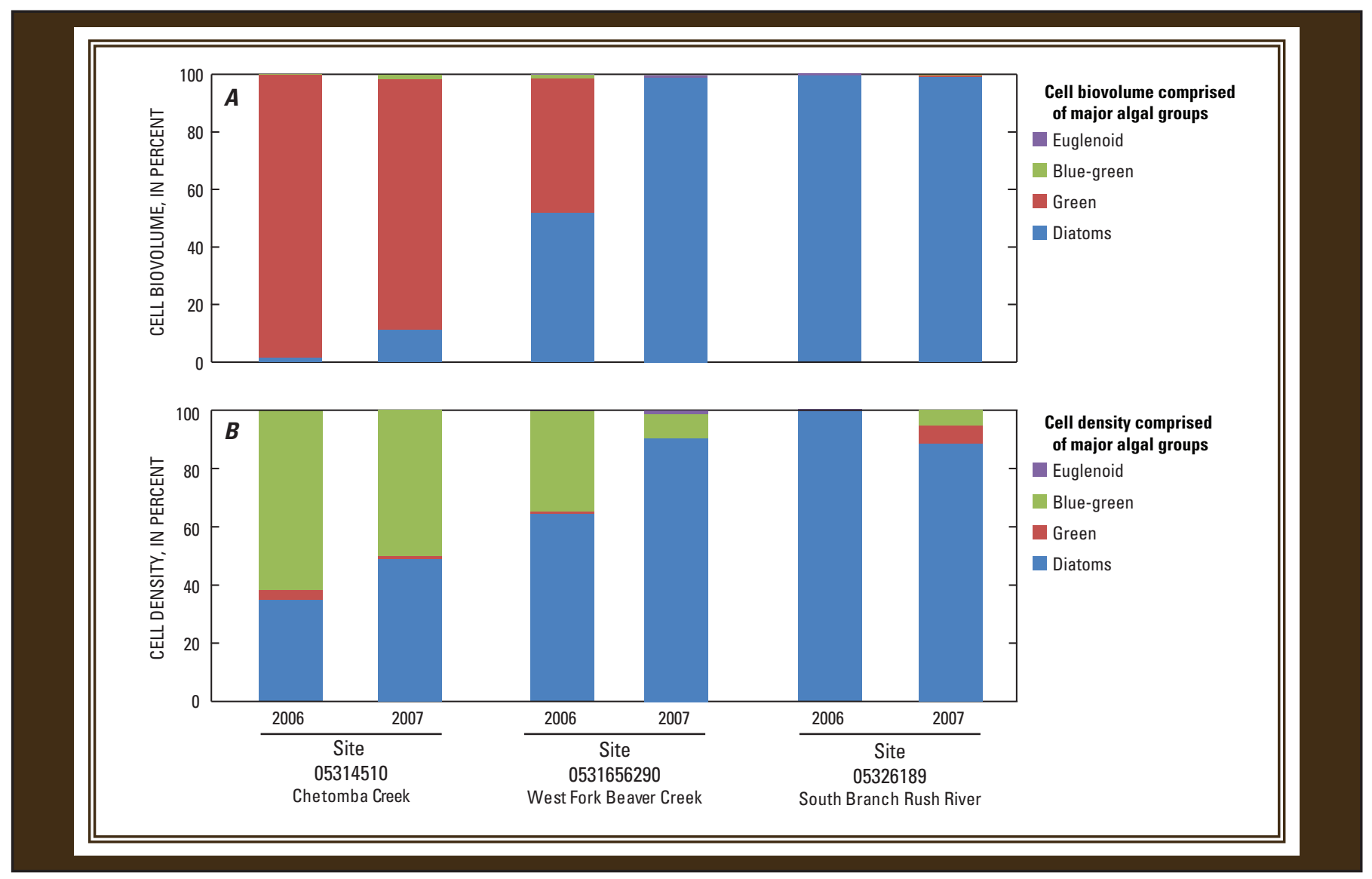

Figure 13. Distribution of algal taxa at selected sampling sites in the Minnesota River Basin by $A$, cell biovolume and $B$, cell density, August 2006 and July 2007. Location of sampling sites shown in figure 1.

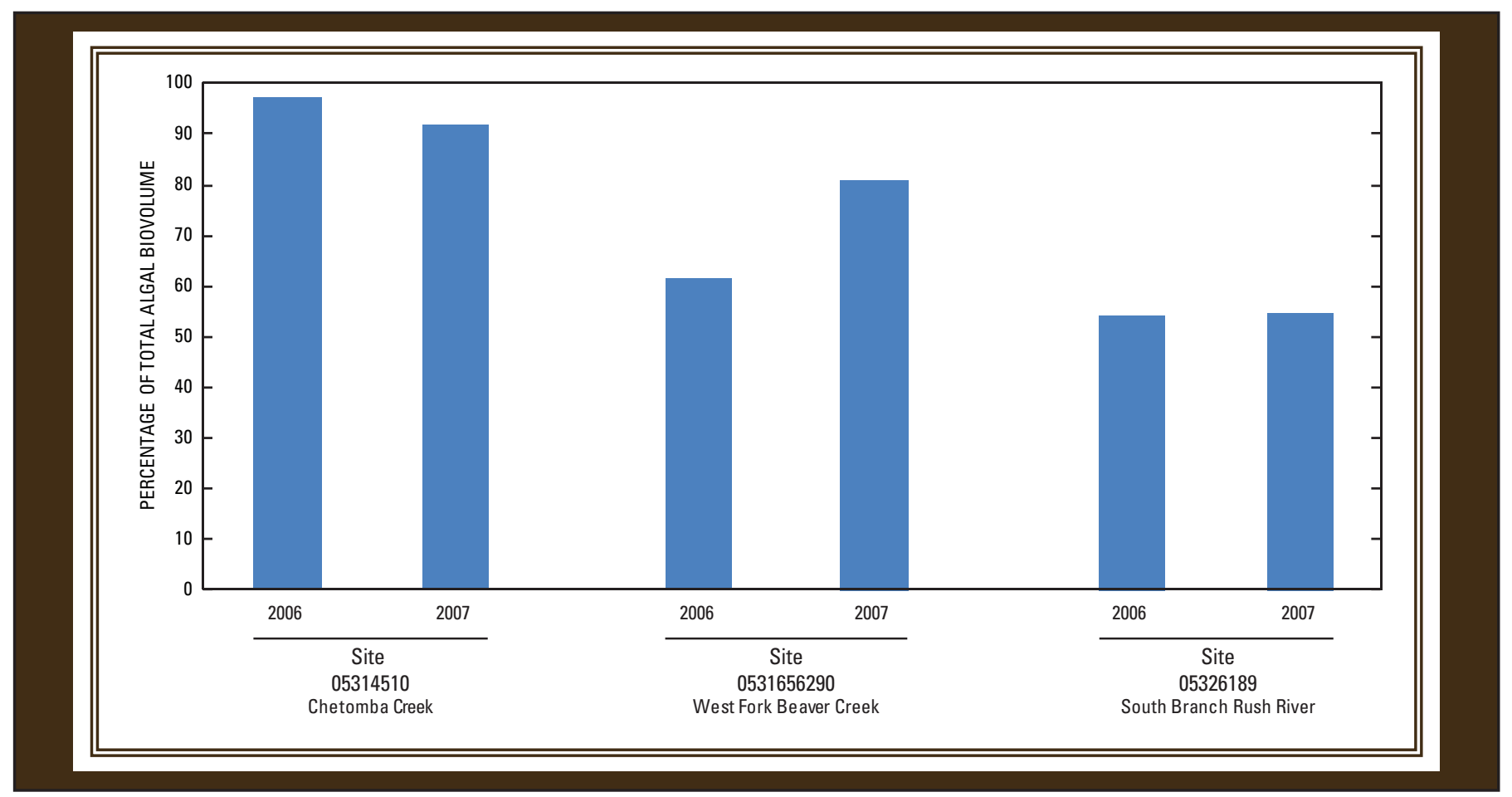

Figure 14. Percentage of total algal biovolume represented by the three most abundant taxa at selected sampling sites in the Minnesota River Basin, August 2006 and July 2007. Location of sampling sites shown in figure 1. 


\section{Benthic Invertebrate Community Characteristics}

Benthic invertebrates are used extensively as indicators of water quality because they form permanent and relatively immobile stream communities, are quick to react to environmental change, and are a major source of food for fish and other aquatic species. Invertebrate composition and community structure are determined by physical and chemical environmental factors. Among all three primary stream sampling sites (05314510, 0531656290, 05326189; fig. 1), 72 benthic invertebrate taxa were collected, of which 53 were in the class insecta (app. 2). The remaining 19 noninsect taxa were distributed among the following classes: Hirudinea, Oliogochaeta, Malacostraca, Bivalvia, Gastropoda, Nematoda, and Nematophora. The insect taxa were distributed among the following orders: Diptera (27 taxa), Ephemeroptera (9), Coleoptera (5), Trichoptera, (5), Odonata (4), Hemiptera (2), and Collembola (1).

Taxa richness provides an estimate of the number of different taxa a stream can support, and presumably streams with more diverse in-stream habitat and suitable chemical conditions can support a larger number of taxa. Invertebrate taxa richness was least at the West Fork Beaver Creek site, whereas the South Branch Rush River and Chetomba Creek sites had greater invertebrate richness during August 2006 and July 2007 (table 12). Insect taxa richness followed a similar pattern (fig. 15).

The composition of the invertebrate community provides additional insight into the physical and chemical conditions at a site. Some macroinvertebrates (for example, Diptera and Oligochaeta) tend to be tolerant of poor waterquality conditions. Other organisms (for example, the orders Ephemeroptera [mayflies], Plecoptera [stoneflies], and Trichoptera [caddisflies]) are more sensitive to organic and nutrient conditions. Numerous sensitive taxa are expected only at sites with good water quality. Diptera were the dominant taxa in terms of taxa richness at all three stream sampling sites (table 12; fig. 15). No Plecoptera were present in any of the streams sampled likely due to the absence of suitable habitat (hard substrates with little silt cover), warm-water temperatures, and no rapidly flowing water. The percentage of taxa classified as Ephemeroptera and Trichoptera varied among sites and temporally for each site. During August 2006, the South Branch Rush River site had the most combined Ephemeroptera and Trichoptera richness followed by the West Fork Beaver Creek and Chetomba Creek sites. During July 2007, the Chetomba Creek site had the most taxa richness, and the South Branch Rush River site had the least.

The distributions of invertebrate taxa on the basis of abundance also were indicative of stream conditions. Invertebrate abundance varied among primary sampling sites and temporally for each site (fig. 16). During August 2006, the invertebrate abundance at the West Fork Beaver Creek and South Branch Rush River sites consisted predominantly of Ephemeroptera, whereas the Chetomba Creek site consisted predominantly of Diptera. During July 2007, the Chetomba
Creek and West Fork Beaver Creek sites had more relative abundance of Ephemeroptera and Trichoptera than the South Branch Rush River site, which was dominated by Diptera.

All three stream sampling sites were dominated by very few taxa, which can be indicative of an unstable community. The abundance of taxa was dominated (more than 35 percent) by one taxa at all three sampling sites (table 12). The freshwater snail (Physella sp.), an aquatic worm (Megadrile), and a burrowing midge (Dicrontendipes sp.) were the dominant organisms at the Chetomba Creek site during August 2006. These taxa generally are indicative of nutrient enrichment, live in depositional habitats, and feed by collecting or scraping (Pennak, 1989; Merritt and Cummins, 1996; U.S. Environmental Protection Agency, 2008).

The dominant taxa at the Chetomba Creek site during July 2007 differed from taxa that were dominant during August 2006 (table 13) but generally were indicative of similar environmental conditions (taxa typically are found in depositional areas with macrophyte cover and are collectors or scrapers). Caenis sp. is a mayfly that typically is found in depositional areas and feeds by collecting and scraping algal cells from rocks (Merritt and Cummins, 1996). Physa sp. is a freshwater snail that occurs where a moderate amount of aquatic vegetation and organic debris occurs (Pennak, 1989). Chironomus sp. is a midge in the family chironomidae and generally is found in depositional environments because they

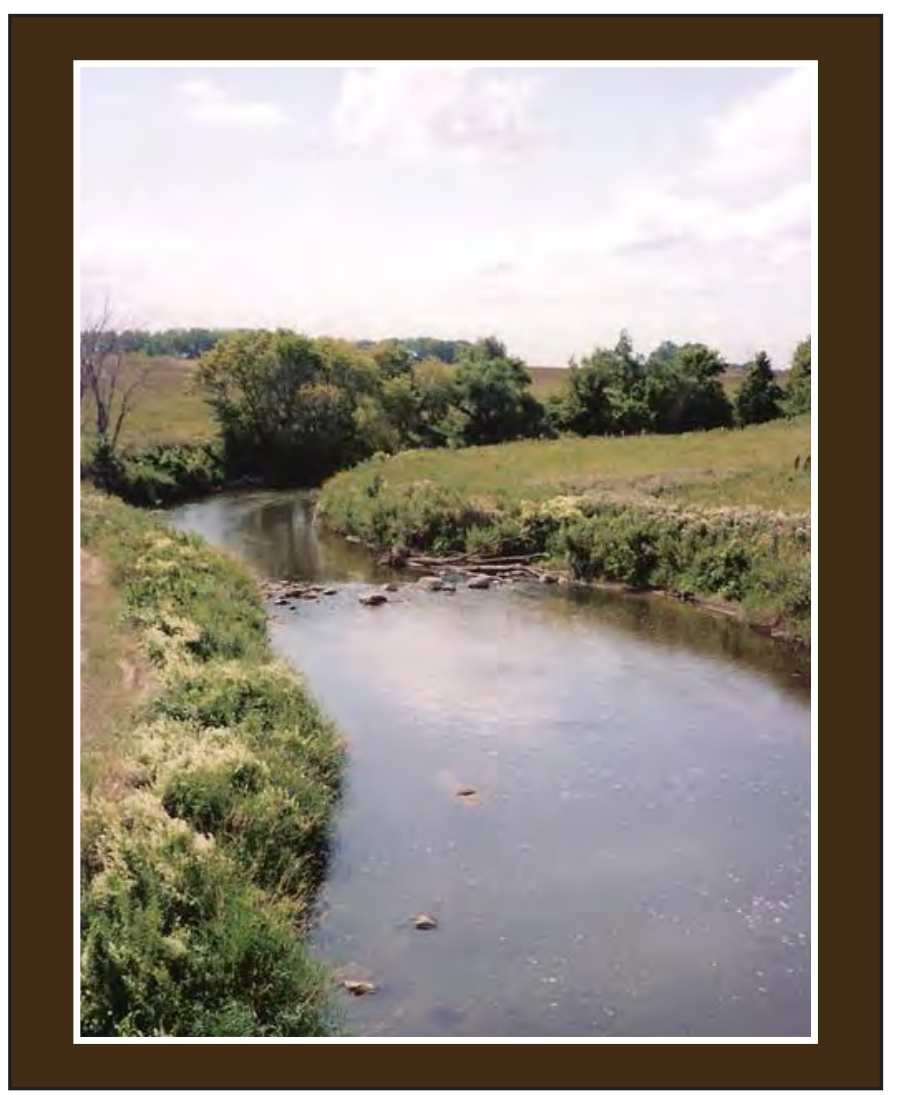


Table 12. Summary of invertebrate community characteristics at selected stream sampling sites in the Minnesota River Basin, August 2006 and July 2007.

\begin{tabular}{|c|c|c|c|c|c|c|}
\hline \multirow{2}{*}{ Physical habitat characteristic } & \multicolumn{2}{|c|}{$\begin{array}{c}\text { Chetomba Creek } \\
\text { (site 05314510, fig. 1) }\end{array}$} & \multicolumn{2}{|c|}{$\begin{array}{c}\text { West Fork Beaver Creek } \\
\text { (site 0531656290, fig. 1) }\end{array}$} & \multicolumn{2}{|c|}{$\begin{array}{l}\text { South Branch Rush River } \\
\text { (site 05326189, fig. 1) }\end{array}$} \\
\hline & 2006 & 2007 & 2006 & 2007 & 2006 & 2007 \\
\hline Invertebrate taxa richness & 20 & 38 & 14 & 23 & 25 & 25 \\
\hline Ephemeroptera richness & 0 & 6 & 3 & 2 & 5 & 1 \\
\hline Trichoptera richness & 3 & 2 & 1 & 2 & 2 & 1 \\
\hline Diptera richness & 8 & 16 & 7 & 6 & 13 & 12 \\
\hline Percentage of Ephemeroptera ${ }^{1}$ & 0 & 51 & 32 & 41 & 61 & 1 \\
\hline Percentage of Trichoptera ${ }^{1}$ & 4 & 5 & 2 & 14 & 4 & 3 \\
\hline Percentage of Diptera $^{1}$ & 26 & 20 & 12 & 18 & 20 & 32 \\
\hline Percentage of Gastropoda ${ }^{1}$ & 37 & 10 & 0 & 1 & 6 & 48 \\
\hline Percentage of Oligocheata ${ }^{1}$ & 26 & 5 & 42 & 4 & 4 & 3 \\
\hline Percentage of scrapers ${ }^{1}$ & 39 & 13 & 2 & 1 & 3 & 48 \\
\hline Percentage of filter collectors ${ }^{1}$ & .8 & 6 & 2 & 19 & .6 & 18 \\
\hline Percentage of tolerant organisms ${ }^{1}$ & 73 & 25 & 3 & 10 & 5 & 61 \\
\hline $\begin{array}{l}\text { Average abundance-weighted } \\
\text { tolerance score }\end{array}$ & 7.59 & 6.73 & 5.60 & 5.64 & 5.89 & 7.29 \\
\hline Percentage consisting of one taxa ${ }^{1}$ & 36 & 49 & 42 & 41 & 48 & 47 \\
\hline
\end{tabular}

${ }^{1}$ All percentages are based on abundance.

are burrowers and primarily feed by gathering their food (Pennak, 1989; Merritt and Cummins, 1996).

During August 2006, the West Fork Beaver Creek site was dominated by an aquatic worm (Megadrile), a mayfly (Hexagenia sp.), and a riffle beetle (Dubiraphia sp.) (table 13). Worms and Hexagenia mayfly nymphs are two of the most common invertebrates found in depositional environments. Hexagenia is a dominant component of the benthic fauna of muddy and silty sediment in mesotrophic (intermediate level of productivity) rivers (Merritt and Cummins, 1996). Hexagenia ripple their abdomen to force oxygen-rich water through a burrow developed in the soft sediment. Because mayflies cannot survive in water that lacks oxygen, they are good indicators of the amount of organic enrichment. When organic enrichment is slight, a greater density of Hexagenia larvae are expected (Wright and Tidd, 1933). In contrast,
Megadrile is indicative of organic or nutrient enrichment, but the presence of Hexagenia sp. indicates that the enrichment is moderate. During July 2007, the West Fork Beaver Creek site was dominated again by the mayfly Hexagenia sp. and the Trichoptera Cheumatopsyche sp., which generally are found in warm streams and are net spinners with fixed retreats that feed by filtering algae and detritus (Merritt and Cummins, 1996). Stictochironomus sp., the third-most dominant organism at the West Fork Beaver Creek site during July 2007, is a burrowing midge that is found in depositional habitats and feeds by gathering algal cells and detritus.

During August 2006, the South Branch Rush River site was dominated by a mayfly (Caenis sp.), a midge (Paratanytarsus sp.), and a riffle beetle (Dubiraphia sp.) (table 13). These organisms in combination are indicative of ample algal resources existing on hard substrates and in the 


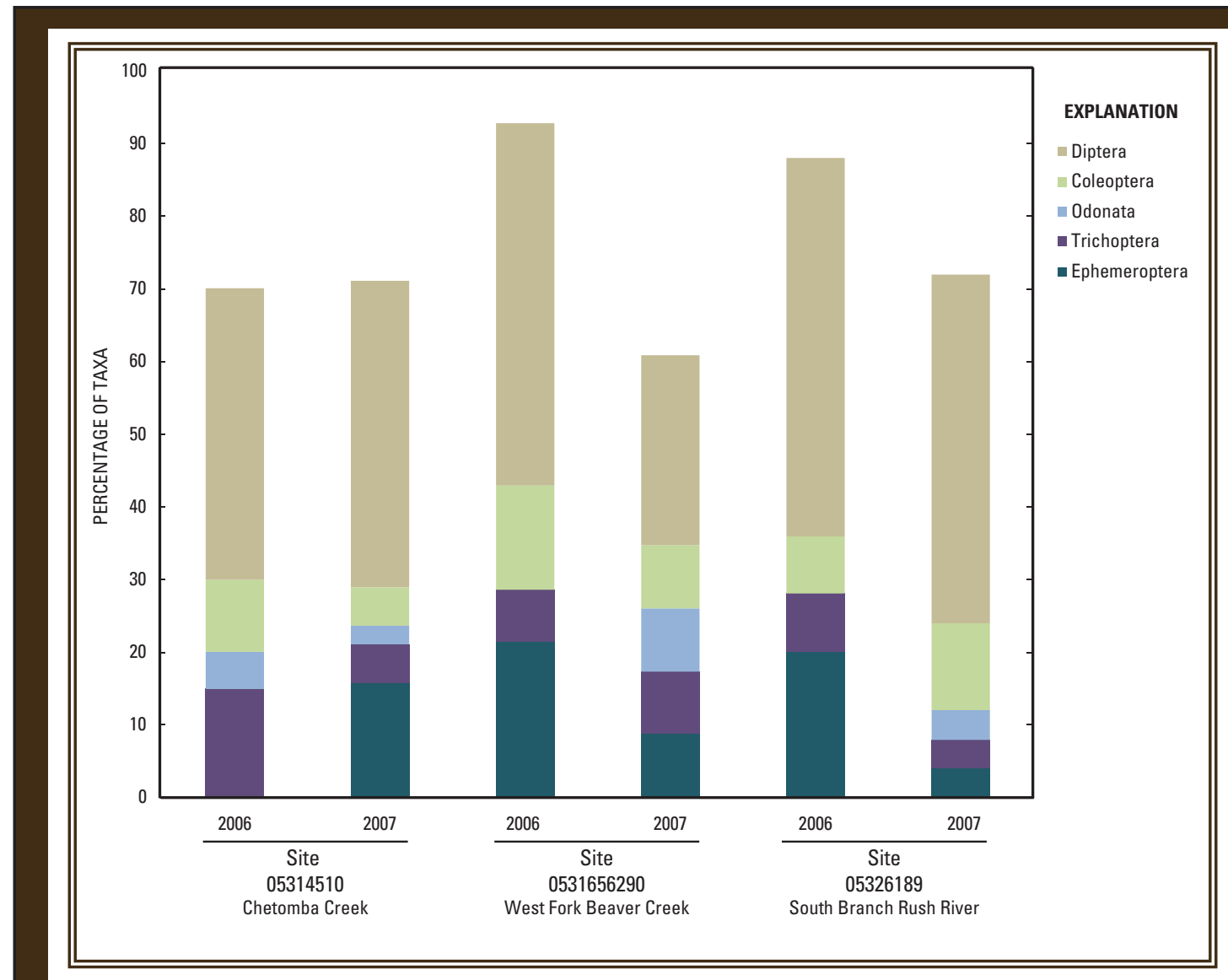

Figure 15. Distribution of insect taxa richness among insect orders at selected sampling sites in the Minnesota River Basin, August 2006 and July 2007. Location of sampling sites shown in figure 1.

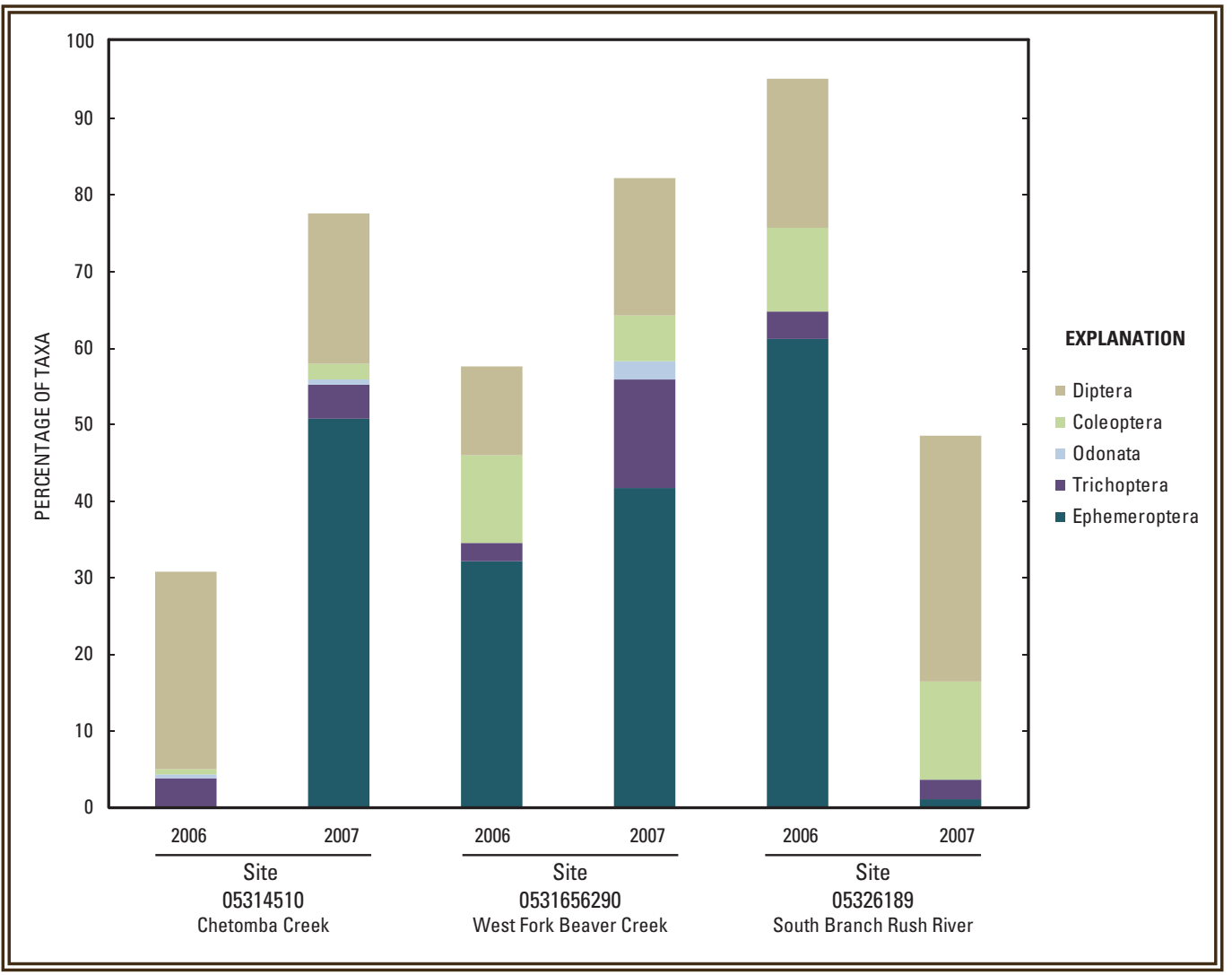

Figure 16. Distribution of invertebrate taxa abundance at selected sampling sites in the Minnesota River Basin, August 2006 and July 2007. Location of sampling sites shown in figure 1. 
Table 13. Percentage of total taxa abundance consisting of the three most abundant taxa collected at selected stream sampling sites in the Minnesota River Basin, August 2006 and July 2007.

\begin{tabular}{|c|c|c|c|c|}
\hline Site name (fig. 1) & $\begin{array}{l}\text { Collection } \\
\text { year }\end{array}$ & $\begin{array}{l}\text { Most abundant } \\
\text { taxa (percentage } \\
\text { abundance) }\end{array}$ & $\begin{array}{l}\text { Second-most abundant } \\
\text { taxa (percentage } \\
\text { abundance) }\end{array}$ & $\begin{array}{l}\text { Third-most abundant taxa } \\
\text { (percentage abundance) }\end{array}$ \\
\hline \multirow[t]{2}{*}{ Chetomba Creek (site 05314510) } & 2006 & Physella sp. (36) & Megadrile (26) & Dicrotendipes sp. (8) \\
\hline & 2007 & Caenis sp. (49) & Physa sp. (10) & Chironomus sp. (6) \\
\hline \multirow{2}{*}{$\begin{array}{l}\text { West Fork Beaver Creek (site } \\
\text { 0531656290) }\end{array}$} & 2006 & Megadrile (42) & Hexagenia sp. (28) & Dubiraphia sp. (10) \\
\hline & 2007 & Hexagenia sp. (40) & Cheumatopsyche sp. (13) & Stictochironomus sp. (11) \\
\hline \multirow{2}{*}{$\begin{array}{l}\text { South Branch Rush River (site } \\
\text { 05326189) }\end{array}$} & 2006 & Caenis sp. (48) & Paratanytarsus sp. (10) & Dubiraphia sp. (9) \\
\hline & 2007 & Physa sp. (47) & Microtendipes sp. (18) & Dubiraphia sp. (12) \\
\hline
\end{tabular}

water column and are found in flowing water (Merritt and Cummins, 1996). During July 2007, the dominant organisms were reflective of similar environmental conditions as during August 2006.

The largest average abundance-weighted tolerance score and the largest percentage of taxa classified as tolerant occurred at the Chetomba Creek site (table 12). The abundance-weighted values were calculated by weighting the tolerance value by the abundance of the organisms in a sample. Tolerance values range from 0 to 10 , where 0 represents the most sensitive organisms and 10 represents the most tolerant organisms (table 14). A larger abundanceweighted tolerance value indicates that the communities at the sampling sites consisted of more organisms considered tolerant. On the basis of Hilsenhoff's (1987) abundanceweighted scores, the Chetomba Creek site was rated "fairly poor to poor" (table 14), the West Fork Beaver Creek was rated "fair," and the South Branch Rush River was rated "fair to fairly poor."

\section{Fish Community Characteristics}

Twenty-one species of fish within five families were collected among all sites and time periods. The majority of fish were in the Cyprinidae family (12) followed by two taxa each of the remaining families (Cataostomidae, Centarchidae, Gasterosteidae, Ictaluridae, and Percidae). Most of the fish collected were invertivores, planktivores, or detrivores, and five of the taxa were classified as tolerant fish. At the Chetomba Creek site, fathead minnows (Pimephales notatus), creek chubs (Semolitus atromaculatus), and bigmouth shiners (Notropis dorslalis) composed most (more than 50 percent) of the fish taxa abundance during August 2006, and creek chubs composed most of the abundance during August 2007.
At the West Fork Beaver Creek site, common shiner (Notropis conutus) and bluntnose minnows (Pimephales notatus) composed most of the abundance during August of both years. At the South Branch Rush River site, fathead minnows and bluntnose minnows composed most of the abundance in August 2006, whereas creek chubs composed most of the abundance during August 2007. Additional information on fish community composition is found in appendix 3 .

IBI scores varied among sites (table 15). The IBI is a composite index that evaluates an array of ecological attributes

Table 14. Water-quality-evaluation ratings for abundanceweighted tolerance scores (modified from Hilsenhoff, 1987).

\begin{tabular}{ccc}
\hline $\begin{array}{c}\text { Abundance- } \\
\text { weighted } \\
\text { tolerance } \\
\text { score }\end{array}$ & $\begin{array}{c}\text { Water-quality- } \\
\text { evaluation rating }\end{array}$ & Degree of organic pollution \\
\hline $0-3.50$ & Excellent & $\begin{array}{c}\text { No apparent organic } \\
\text { pollution. } \\
\text { Possible slight organic } \\
\text { pollution. }\end{array}$ \\
$3.51-4.50$ & Very good & $\begin{array}{c}\text { Some organic pollution. } \\
4.51-5.50\end{array}$ \\
$5.51-6.50$ & Good & $\begin{array}{c}\text { Fairly significant organic } \\
\text { pollution. }\end{array}$ \\
$6.51-7.50$ & Fairly poor & $\begin{array}{c}\text { Significant organic } \\
\text { pollution. }\end{array}$ \\
$7.51-8.50$ & Poor & $\begin{array}{c}\text { Very significant organic } \\
\text { pollution. }\end{array}$ \\
$8.51-10.00$ & Very poor & Severe organic pollution. \\
\hline & &
\end{tabular}


of fish communities. Six classes (exceptional, good, fair, poor, very poor, and no fish) were used to rate three streams in the Minnesota River Basin. IBI scores indicated poor quality at all stream sampling sites during both sampling periods, except for the West Fork Beaver Creek site, which had a rating of "fair" during August 2006. IBI scores generally decrease with increasing physical and chemical perturbations such as poor water quality, poor in-stream habitat, and migration barriers (Karr and others, 1985). Two of the metrics that affected the overall IBI score, species richness (the number of fish taxa collected) and percentage of tolerant fish, show that the West Fork Beaver Creek site had a moderate number of fish species and the smallest percentage of tolerant species, whereas the South Branch Rush River site had a moderate number of fish species and a large percentage of tolerant species.

In addition to small percentages of retired land, the upstream Chetomba Creek site had very little in-stream habitat diversity with the exception of very dense macrophyte and macroalgae mats that may not provide good habitat potentially due to increased dissolved oxygen variability. The number of fish species collected indicates better resource quality for the West Fork Beaver Creek site than for the other stream sampling sites likely due to a combination of factors, including habitat quality, food resources, and dissolved oxygen characteristics. The larger IBI score for the West Fork Beaver Creek site, compared to the Chetomba Creek and South Branch Rush River sites, coincides with larger percentages of retired agricultural land (table 4) and diversity of physical habitat cover types. Although the substrate at the West Fork Beaver Creek site was primarily silt and clay, which is not preferable for many fish and invertebrate species, a lack of extensive macroalgae cover may lead to more stable dissolved oxygen conditions within this stream.

\section{Water-Quality and Biological Responses to Agricultural Land Retirement}

This section of the report describes the water-quality and biological responses of three streams in the Minnesota River

Table 15. Summary of fish community characteristics at selected stream sampling sites in the Minnesota River Basin, August 2006 and 2007.

\begin{tabular}{|c|c|c|c|c|c|c|}
\hline \multirow{2}{*}{ Physical habitat characteristic } & \multicolumn{2}{|c|}{$\begin{array}{c}\text { Chetomba Creek } \\
\text { (site 05314510, fig. 1) }\end{array}$} & \multicolumn{2}{|c|}{$\begin{array}{l}\text { West Fork Beaver Creek } \\
\text { (site 0531656290, fig. 1) }\end{array}$} & \multicolumn{2}{|c|}{$\begin{array}{l}\text { South Branch Rush River } \\
\text { (site 05326189, fig. 1) }\end{array}$} \\
\hline & 2006 & 2007 & 2006 & 2007 & 2006 & 2007 \\
\hline Number of fish species collected & 8 & 9 & 13 & 15 & 16 & 11 \\
\hline Number of darter species & 1 & 1 & 1 & 1 & 1 & 1 \\
\hline Number of minnow species & 2 & 3 & 7 & 8 & 6 & 5 \\
\hline Number of intolerant species & 0 & 0 & 1 & 1 & 1 & 0 \\
\hline Percentage of tolerant species & 56 & 41 & 8 & 11 & 33 & 78 \\
\hline Percentage of specialized insectivores & 0 & 0 & 5.3 & 1.1 & 2.8 & 0 \\
\hline Percentage of omnivores & 44.7 & 20.1 & 75.7 & 64.3 & 82.2 & 7.4 \\
\hline $\begin{array}{l}\text { Catch per unit effort on all fish } \\
\text { (except tolerant ones) per hour }\end{array}$ & 1,014 & 1,126 & 55 & 259 & 693 & 1,016 \\
\hline Index of biotic integrity (IBI) scores ${ }^{1}$ & 14 & 20 & 30 & 28 & 19 & 23 \\
\hline
\end{tabular}

${ }^{1}$ Bailey and others (1993) was used for fish tolerance classification and IBI calculations; Bailey and others (1993) rates streams with IBI scores of 50-60 as "excellent," 40-49 as "good," 30-39 as "fair," 20-29 as "poor," and 12-20 as "very poor." 
Basin to agricultural land retirement. Comparisons are made among and within the three subbasins.

\section{Comparison Among Subbasins}

Paired basin studies, such as the one presented here, have their challenges. It is difficult to find basins that are similar and impossible to find basins with no differences. The relation between the percentage of agricultural land retirement and stream quality likely is affected by differences among sites. For example, the difference in resource quality for West Fork Beaver Creek when compared to the other two streams may be due in part to factors such as stream geomorphology - a more sinuous stream may cause traveltime to increase, which causes nutrient uptake to increase. In addition to the difficulties in pairing basins, comparison of three sites represents a small sample size, and conditions in the Minnesota River Basin are highly variable from year to year, and therefore it may not be prudent to draw conclusions from such a small data set.

Although dissimilarities exist among the three subbasins, considerable effort was made to select subbasins that were similar with respect to some of the most important factors for water quality and biology (table 3 ). In this section, comparisons are made for the differences in stream quality among the three subbasins and the status of retired agricultural lands in the subbasins.

Concentrations of nitrite plus nitrate and total nitrogen decreased with increasing percentages of retired agricultural land (fig. 17A and 17B) in three streams of the Minnesota River Basin. Nitrite plus nitrate concentrations (table 8) were largest in South Branch Rush River, the subbasin with little or no land retirement, and smallest in Chetomba Creek and West Fork Beaver Creek, subbasins with more total land retirement (table 4).

Total phosphorus concentrations did not decrease with an increase in total (subbasin) land retirement (fig. 17C) at the three primary sampling sites. Total phosphorus concentrations were largest at the sampling site with the largest percentage of retired land within the subbasin, and concentrations increased with increases in the percentage of retired land within the 50-m influence zone. Chlorophyll $a$ (not shown in fig. 17) also did not follow a consistent trend with retired land characteristics except that concentrations were largest at the site with the least amount of retired land within the $50-\mathrm{m}$ influence zone. Chlorophyll- $a$ concentrations had a different trend compared to that of total phosphorus concentrations, with Chetomba Creek having larger chlorophyll- $a$ concentrations at low flow.

The relation of benthic algal, benthic invertebrate, and fish metrics with characteristics of retired agricultural land also was evaluated. Biological responses to retired land varied among the different taxa (algae, invertebrates, and fish) and varied with the proximity of the retired land considered (total subbasin area compared to influence zone). More clear relations were apparent for retired land within the 50-m influence zone than for more remote retired land in the subbasin. The small sample size precludes a statistical analysis; however, the trends observed can provide insight into the effect of retired land characteristics on biological resource quality. Although the algal measures analyzed showed no clear relations, the total algal biovolume (indicator of stream productivity) and the percentage of algal biovolume composed of blue-green algae were largest at the site with the least amount of retired agricultural land within the 50-m influence zone (Chetomba Creek near Renville, site 05314510, fig. 1; tables 4 and 11).

Invertebrates respond to changes in physical habitat, hydrology, food resources, and water chemistry. Each taxon requires a particular physical habitat. Therefore, the absence of taxa may not be an indicator of degraded water quality but rather the absence of suitable physical habitat. Very few of the invertebrate measures were related directly with the percentage of land retirement in the subbasin, possibly due to differences in physical habitat among the streams. However, relations were more apparent between the invertebrate measures and the percentage of retired land within the $50-\mathrm{m}$ influence zone (table 4) than for the total percentage of retired land in the subbasin. One metric that evaluates biological resource quality, the abundance-weighted tolerance score, decreased (improved) with increasing percentage of retired land within the 50-m and 100-m influence zones during August 2006 (fig. 18). That trend was not as clear in July 2007; however, the subbasin with the largest percentage of retired lands within the 50-m influence zone (West Fork Beaver Creek) had the smallest abundance-weighted tolerance score.

The number of fish species collected at each site was not related to the percentage of land retirement (fig. 19B). However, the percentage of tolerant species decreased with increasing percentage of land retirement (fig. 19C), which indicates better resource quality at sites with larger percentages of land retirement. In this study, IBI scores increased as land-retirement percentages within 50- and 100-m influence zones increased (fig. 19A). The relation was not as clear with retired land percentages in wider zones of influence.

\section{Comparison Within Subbasins}

The comparison of stream quality and percentage of retired land within subbasins was assessed in two ways. First, stream quality was assessed by the collection of paired samples at upstream and downstream sites in the Chetomba Creek and South Branch Rush River subbasins. Second, a longitudinal synoptic survey of biomass accumulation was completed in Chetomba Creek at four sites along an area of increasing land retirement.

Total land retirement increased between upstream and downstream sites for both the Chetomba Creek and South Branch Rush River subbasins (table 4). However, the difference in the amount of land retirement between the 


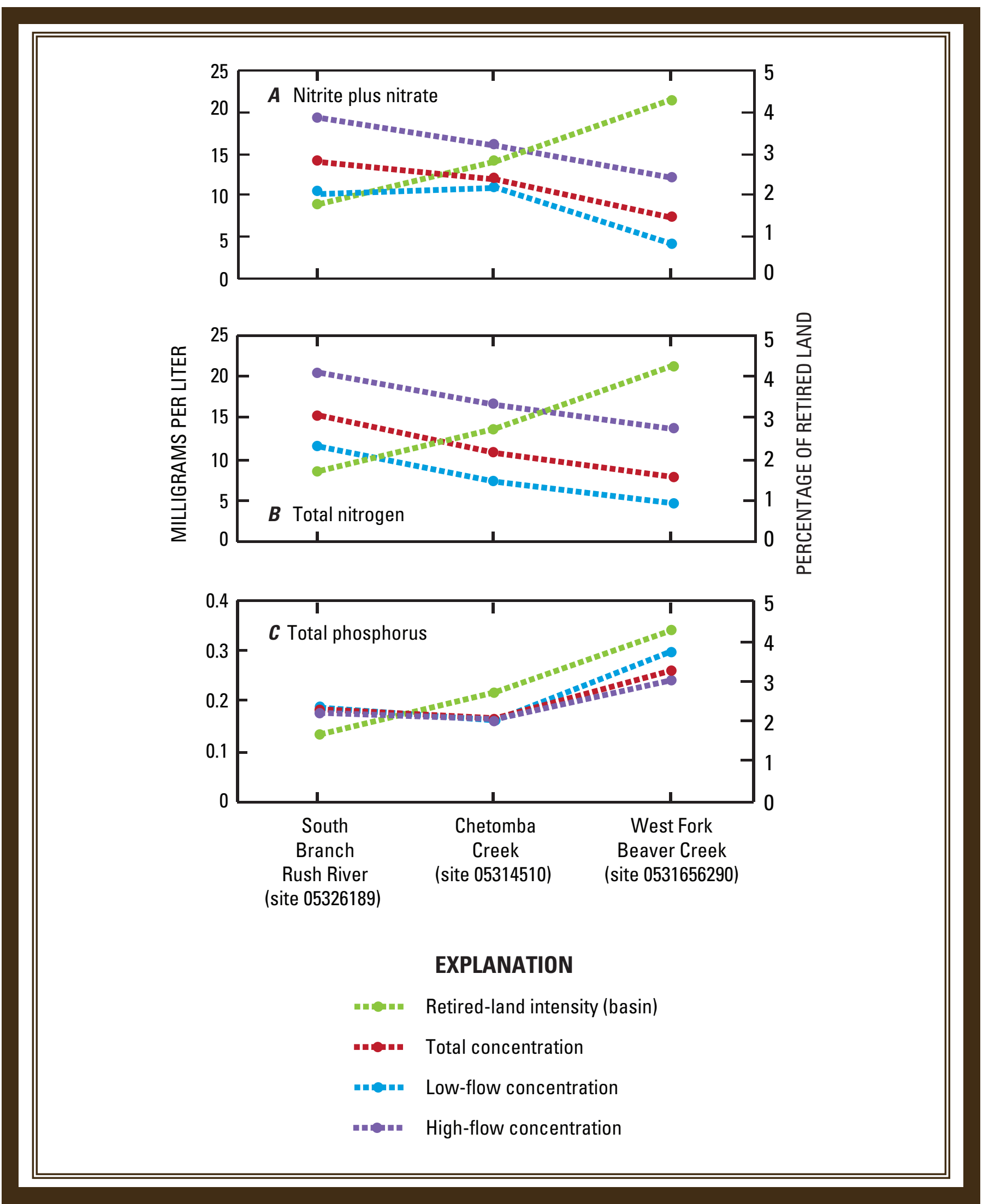

Figure 17. Mean nutrient concentrations of $A$, nitrite plus nitrate. $B$, total nitrogen. $C$, total phosphorus at selected stream sampling sites in order of increasing percentage of agricultural land retirement, Minnesota River Basin, water years 2006-08. Location of sampling sites shown in figure 1. 
secondary South Branch Rush River site (upstream) and the primary site (downstream) was small, whereas the difference in the amount of land retirement between the primary (upstream) and secondary (downstream) sites in the Chetomba Creek subbasin was substantial.

Wilcox signed rank tests (Wilcox, 1997) were performed on the paired samples from the upstream and downstream sites in the Chetomba Creek and South Branch Rush River subbasins to test the significance of the differences shown in figure 20. Results of the signed rank tests were considered significant if $p$-values were equal to or less than 0.05 . When concentrations at the upstream Chetomba Creek near Renville site (05314510) were compared to concentrations at the downstream Chetomba Creek near Maynard site (05314518, Judicial Ditch No. 1), nitrite plus nitrate ( $\mathrm{p}$-value $=0.03)$, total nitrogen $(p$-value $=0.01)$, total phosphorus $(p$-value $=0.03)$, and chlorophyll- $a(\mathrm{p}=0.02)$ concentrations decreased between the sites (fig. 20), and the percentage of retired land within

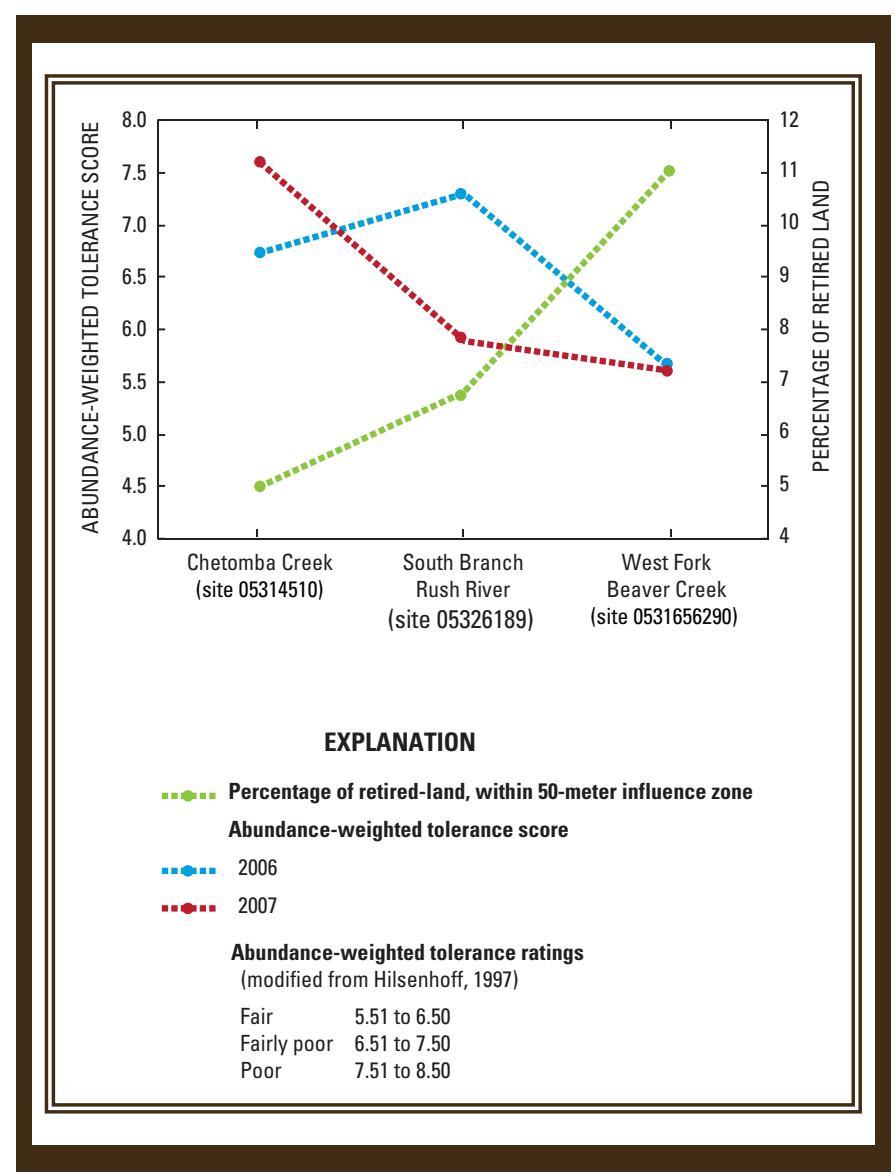

Figure 18. Abundance-weighted tolerance scores for invertebrate taxa collected from Chetomba Creek near Renville, West Fork Beaver Creek near Bechyn, and South Branch Rush River near Norseland, August 2006 and July 2007. Location of sampling sites shown in figure 1.

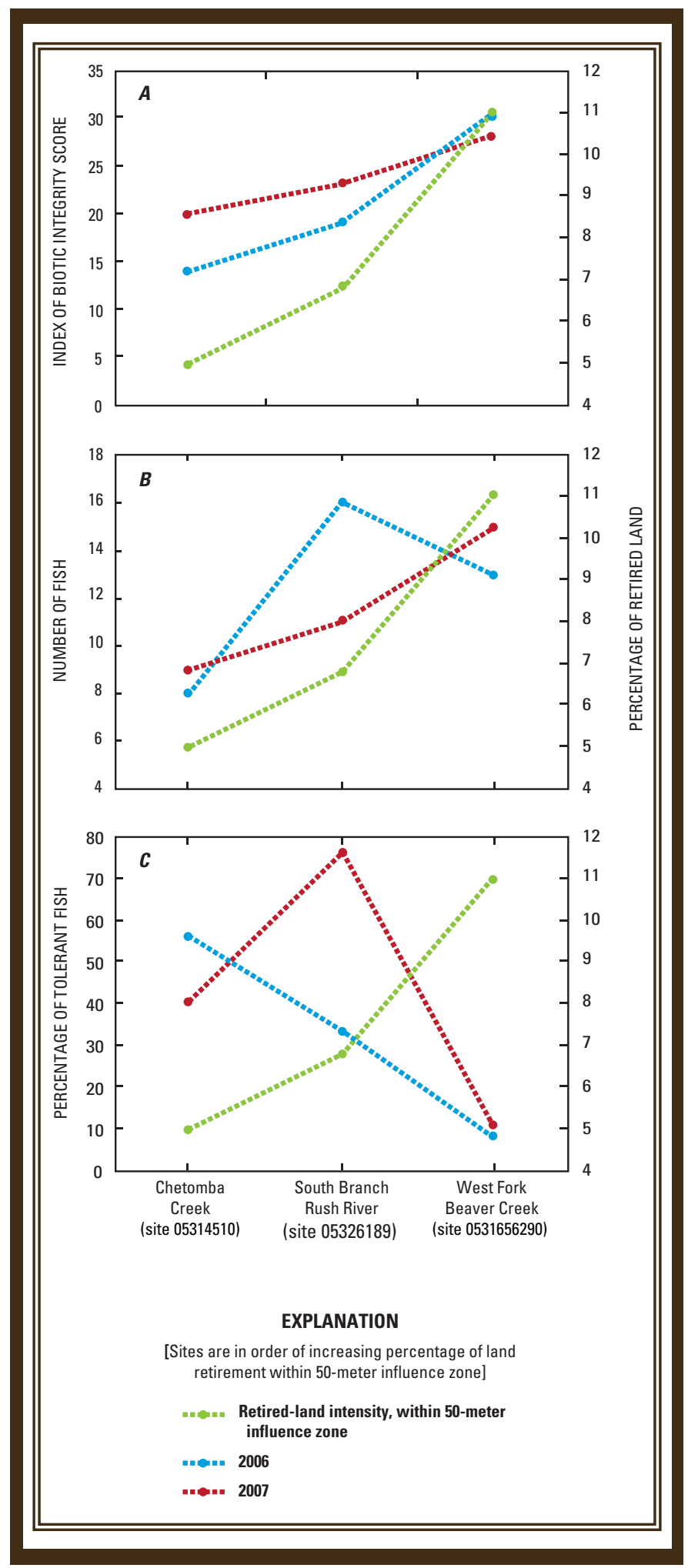

Figure 19. Comparison of agricultural land retirement within the 50-meter influence zone to $A$, index of biotic integrity scores. $B$, Number of fish collected. $C$, Percentage of fish that were classified as tolerant at Chetomba Creek near Renville, South Branch Rush River near Norseland, and West Fork Beaver Creek near Bechyn Minnesota, August 2006 and 2007. Location of sampling sites shown in figure 1. 
the $50-\mathrm{m}$ influence zone increased from 5.01 to 8.18 percent (table 4). Although orthophosphorus concentrations and SSCs decreased as well, these differences were not statistically significant using the Wilcox signed rank test. The decrease in concentrations between the upstream and downstream sites may indicate that the retired land between the two sites leads to improved water quality. However, the drop structure located at the Maynard site may trap sediment and associated nutrients and, therefore, also may result in smaller total nutrient concentrations downstream.

South Branch Rush River sites also are compared in figure 20. Similar to the Chetomba Creek sites, the concentrations in the South Branch Rush River subbasin decreased with increasing land retirement with the exception of seston chlorophyll- $a$ concentrations. However, none of these decreases were statistically significant. The results of the Wilcox signed rank test indicated that the subbasin with a larger downstream increase in retired lands (Chetomba Creek) had statistically significant decreases in four of six constituents, whereas the subbasin with a smaller downstream increase in land retirement (South Branch Rush River) had no statistically significant difference between upstream and downstream nutrient and chlorophyll- $a$ concentrations and SSC.

For the longitudinal synoptic survey of the Chetomba Creek subbasin, periphytometer data were assessed in August 2008. At Chetomba Creek site 05314517 (the farthest downstream site where periphytometers were deployed), the benthic algae growth rate was limited by the supply of phosphorus (fig. 21). At this site, the mean algal growth

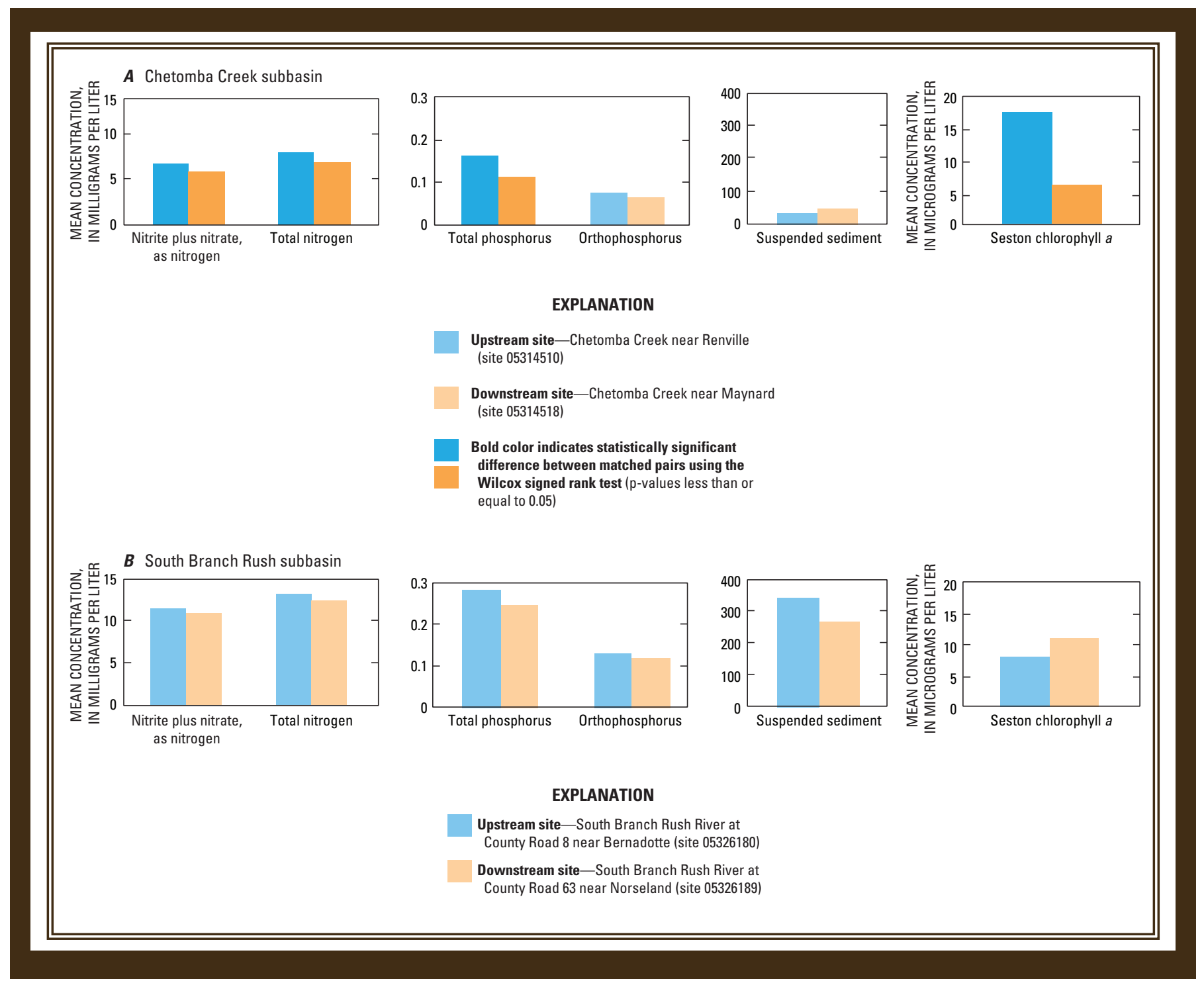

Figure 20. Comparison of upstream and downstream water-quality data at $A$, Chetomba Creek near Renville and Maynard. $B$, South Branch Rush River at County Road 8 near Bernadotte and South Branch at County Road 63 near Norseland, water years 2006-08. Location of sampling sites shown in figure 1. 
rate on the periphytometers that were used as controls was substantially less than the mean phosphorus $(\mathrm{P})$ addition growth rate and the phosphorus plus nitrogen $(\mathrm{P}+\mathrm{N})$ addition growth rate. The mean control growth rate at site 05314517 was similar to the mean control growth rates at Chetomba Creek sites 05314518 and 05314516, and these were substantially less than the mean control growth rate at Chetomba Creek site 05314515.

In contrast to the phosphorus limitation at Chetomba Creek site 05314517, the remaining sites showed very little difference between nutrient treatments. This indicates that the three upstream sampling sites are saturated with respect to nitrogen and phosphorus. Once the water reaches the downstream periphytometer site (05314517), it becomes phosphorus limited. This may be an indication that the increase in land retirement between the upstream and downstream sites reduces the supply of phosphorus to the stream. Further study would be needed to determine if phosphorus is being removed from the system by another mechanism.

\section{Implications}

The data collected during water years $2006-08$ provide information on responses that a watershed may have to agricultural land retirement. The characterization of waterquality and biological data from Chetomba Creek, West Fork Beaver Creek, and South Branch Rush River may be used as a baseline for future studies as land-retirement conditions change in these subbasins. The finding that there are some

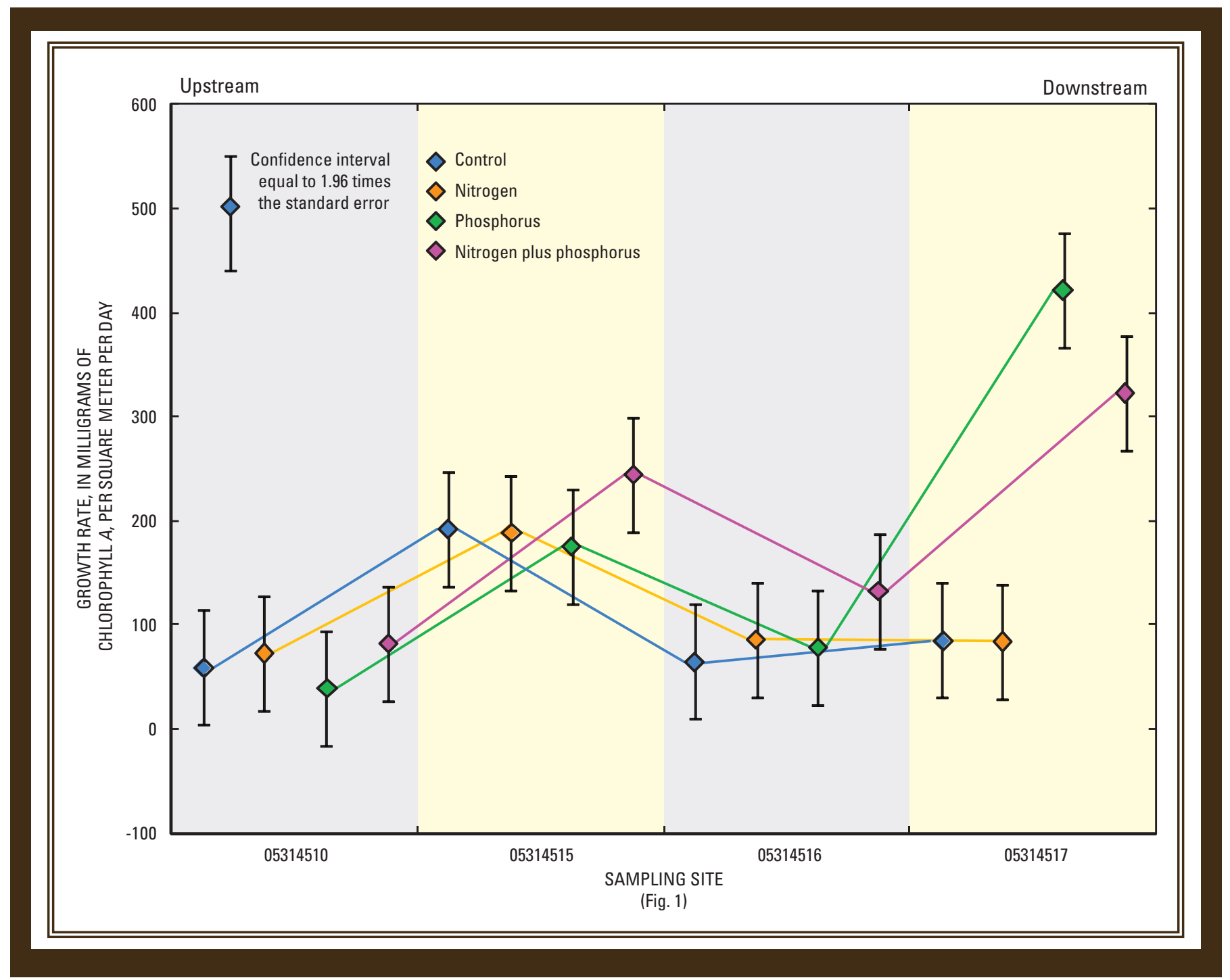

Figure 21. Mean growth rates for Chetomba Creek periphytometer deployments, August 2008. 
water-quality and biological improvements with increasing land retirement percentages may have implications for prioritizing land in retirement programs in the Minnesota River Basin and other basins. Currently (2009), landretirement contracts are decreasing across the Midwest because of the increase in corn prices. This study could serve as a foundation for future studies should land retirement in these basins decrease substantially. If land-retirement contracts shift to favor upland CRP, the benefits between riparian and upland CRP may be addressed. Data and analysis from this study can be used to evaluate the success of agricultural management practices and land-retirement programs for improving stream quality.

\section{Summary}

Retired agricultural land is assumed by many to improve water quality and aquatic-resource quality by reducing surface runoff and reducing agricultural chemical entry into streams. Water-quality and biological characteristics and the effects of agricultural land retirement on water-quality conditions, including nutrient and suspended-sediment concentrations and on biological conditions of three streams in the Minnesota River Basin were assessed by the U.S. Geological Survey in cooperation with the Minnesota Board of Water and Soil Resources using data collected during water years 2006-08. The Chetomba Creek, West Fork Beaver Creek, and South Branch Rush River subbasins, which range in size from about 200 to 400 square kilometers, have similar geologic and hydrologic settings but differ with respect to the amount, type, and location of retired land.

Temporal variability in water quality was evaluated with in-stream water-quality monitors and collection of samples during storms. Considerable variability in physical properties was evident among sites, seasonally, and during storms. Specific conductance in the three streams tended to vary with streamflow, decreasing during high streamflow. Specific conductance decreased throughout the growing season. Water temperature increased during the summer months, with occasional decreases occurring during storms. In addition to seasonal and runoff-driven fluctuations, temperature also varied diurnally at all sampling sites, which is a concern to streams because aquatic organisms are adapted to a certain temperature range. Dissolved oxygen also had substantial diurnal variability. Diurnal variability in $\mathrm{pH}$, temperature, and dissolved oxygen can be attributed to several factors, including photosynthesis, reaeration, respiration, and plant uptake.

Turbidity is an event-driven property of water, which typically increases with increases in streamflow, but also increases with other stream disturbances, such as animal activity. West Fork Beaver Creek had larger ambient turbidity but with fewer event-driven increases in turbidity than the other streams.

Total nitrogen concentrations were largest, with a mean of 15.0 milligrams per liter (mg/L), in the South Branch Rush
River near Norseland, the subbasin with little to no land retirement. Total nitrogen concentrations were smaller in Chetomba Creek near Renville (mean of $10.6 \mathrm{mg} / \mathrm{L}$ ) and West Fork Beaver Creek near Bechyn (mean of $7.9 \mathrm{mg} / \mathrm{L}$ ), which are subbasins with more riparian or upland land retirement.

Total phosphorus concentrations were not related directly to differing percentages of land retirement, with mean concentrations at primary data-collection sites of $0.164 \mathrm{mg} / \mathrm{L}$ in the Chetomba Creek subbasin, $0.259 \mathrm{mg} / \mathrm{L}$ in the West Fork Beaver Creek subbasin, and $0.180 \mathrm{mg} / \mathrm{L}$ in the South Branch Rush River subbasin. In this study, both nitrogen and phosphorus concentrations were smallest in the subbasin with the largest percentage of retired land (Chetomba Creek). Nitrogen concentrations were largest in the subbasin with little or no land retirement (South Branch Rush River).

Several storms occurred in the study area during water years 2006-08. During the storms, 10 sets of storm samples were collected. The storm size (streamflow increase) and suspended-sediment response varied. Following most of the larger storms, the suspended-sediment concentration initially was large and gradually decreased as streamflow decreased. Some storm sediment concentrations exhibited hysteresis - where suspended-sediment concentration at a given streamflow on the rising limb of the hydrograph differs from that at the same streamflow on the falling limb. The lag time between peak suspended-sediment concentrations and the peak streamflow among sites and storms may be affected by antecedent moisture conditions, depletion of sediment from runoff during the storm, or the increased portion of base flow

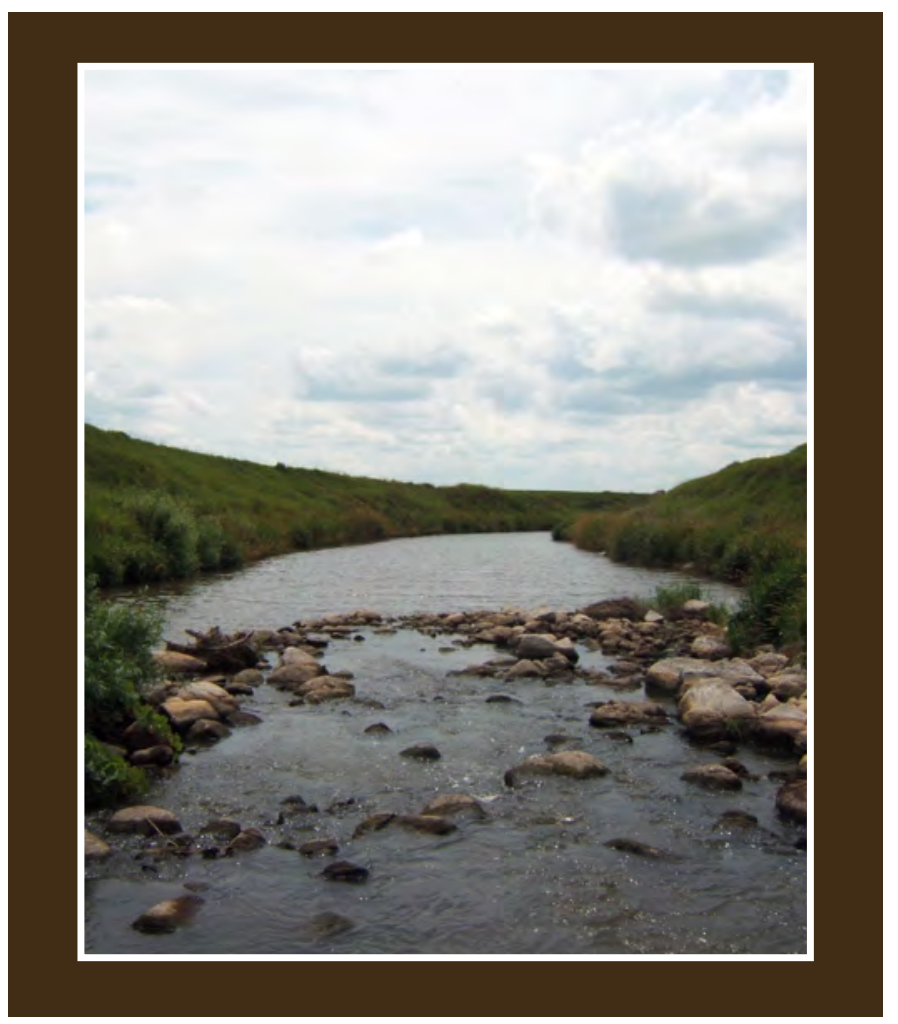


during the recession limb of the hydrograph. This pattern of peak suspended-sediment concentrations occurring before the peak streamflow has been identified for other Minnesota River tributaries and has been attributed to artificial drainage. As streamflow from a storm decreases, a larger percentage of the flow is supplied by tile drains, and water from tile drains contains virtually no suspended sediment.

Benthic algae, benthic invertebrates, and fish samples were collected during August 2006 and July 2007. A total of 134 algal taxa were collected in the three subbasins during August 2006 and July 2007. A substantial portion of benthic algae in all three streams are those found in mesoeutrophic to eutrophic conditions. The majority of the taxa collected were diatoms. However, the percentages of taxa richness, biovolume, and density at the Chetomba Creek sampling site (near Renville) were largest for blue-green algae.

Seventy-two benthic invertebrate taxa were collected among all three streams, mostly in the class insecta. In August 2006 and July 2007, Chetomba Creek had the largest abundance-weighted tolerance scores (indicating poor resource quality) compared to South Branch Rush River, which had moderate tolerance scores, and West Fork Beaver Creek, which had smaller abundance-weighted tolerance scores (indicating generally good resource quality). All three streams were dominated by very few taxa, which can be indicative of an unstable community.

Twenty-one species of fish within five families were collected at the three primary sampling sites during August 2006 and 2007. Fish data indicated more favorable resource quality for the West Fork Beaver Creek than for the other two streams, likely due to a combination of factors including habitat quality, food resources, and dissolved oxygen characteristics. Index of biotic integrity (IBI) scores increased as percentages of land retirement within the 50 - and 100 -meter influence zones increased.

Concentrations at upstream and downstream Chetomba Creek subbasin sampling sites, Chetomba Creek near Renville and near Maynard (Judicial Ditch No. 1), were compared using a Wilcox signed rank test for matched pairs of samples. The differences were statistically significant ( $p$-values equal to or less than 0.05 ) for concentrations of nitrite plus nitrate, total nitrogen, total phosphorus, and chlorophyll $a$. These constituents decreased as the percentage of retired land in the 50-meter influence zone increased from 5.01 to 8.18 percent. When concentrations at the upstream and downstream sampling sites in the South Branch Rush River subbasin were compared, none of the differences were statistically significant. The subbasin with a substantial downstream increase in retired lands (Chetomba Creek) had a larger decrease in nutrient and chlorophyll- $a$ concentrations than the subbasin with little downstream change in land retirement (South Branch Rush River).

Primary productivity was assessed during a longitudinal synoptic survey of Chetomba Creek in August 2008. Primary productivity estimates that were based on biomass accumulation indicated that the periphyton growth rate was limited by the supply of phosphorus at the most downstream site on Chetomba Creek. This may be an indication that the increase in land retirement between the upstream and downstream sites decreases the supply of phosphorus to the stream.

The data collected during water years 2006-08 provide information on responses that a watershed may have to agricultural land retirement. Land owners, scientists, and local, State, and Federal agencies can use this information to evaluate the success of agricultural management practices and land-retirement programs for improving stream quality.

\section{References Cited}

Allan, J.D., 1995, Stream ecology - structure and function of running waters: London, Chapman and Hall, 388 p.

Allen, Arthur, 2005, The Conservation Reserve Enhancement Program, in Haufler, J.B., ed., Fish and wildlife benefits of farm bill conservation programs-2000-2005 update: Wildlife Society Technical Review 05-2, p. 115-132.

Arar, E.J., and Collins, G.B., 1997, Methods 445.0, In vitro determination of chlorophyll $a$ and pheophyton $a$ in marine and freshwater algae by fluorescence, in Methods for the determination of chemical substances in marine and estuarine environmental matrices ( $2 \mathrm{~d}$ ed.): Cincinnati, Ohio, National Exposure Research Laboratory, Office of Research and Development, U.S. Environmental Protection Agency, EPA/600/R-97/072, p. 1-22.

Asselman, N.E.M., 1999, Suspended sediment dynamics in a large drainage basin - the River Rhine: Hydrological Processes, v. 13, p. 1437-1450.

Asselman, N.E.M., 2000, Fitting and interpretation of sediment rating curves: Journal of Hydrology, v. 234, p. 228-248.

Bahls, L.L., 1993, Periphyton bioassessment methods for Montana streams: Helena, Mont., Water Quality Bureau, Department of Health and Environmental Services, 69 p.

Bailey, P.A., Enblom, J.W., Hanson, S.R., Renard, P.A., and Schmidt, Konrad, 1993, A fish community analysis of the Minnesota River Basin: Saint Paul, Minnesota Pollution Control Agency, variously paged.

Baker, R.A., 1980, Fate and transport, case studies, modeling, toxicity, v. 1 of Contaminants and sediments: Ann Arbor, Mich., Ann Arbor Science, 558 p.

Baker, N.T., Stone, W.W., Wilson, J.T., and Meyer, M.T., 2006, Occurrence and transport of agricultural chemicals in Leary Weber Ditch Basin, Hancock County, Indiana, 2003-04: U.S. Geological Survey Scientific Investigations Report 2006-5251, 44 p. 
Barbour, M.T., Gerritson, J., Snyder, B.D., and Stribling, J.B., 1999, Rapid bioassessment protocols for use in streams and wadeable rivers - periphyton, benthic macroinvertebrates and fish (2d ed.): Washington, D.C., U.S. Environmental Protection Agency, EPA/841/B-99/002.

Battaglin, W.A., and Goolsby, D.A., 1999, Spatial data in geographic information system format on agricultural chemical use, land use and cropping practices in the United States: U.S. Geological Survey Water-Resources Investigations Report 94-4176, accessed Sept. 17, 2009, at http://pubs.er.usgs.gov/usgspubs/wri/wri944176.

Britton, L.J., and Greeson, P.E., eds., 1987, Methods for collection and analysis of aquatic biological and microbiological samples: U.S. Geological Survey Techniques of Water-Resources Investigations, book 5, chap. A4, variously paginated.

Buchanan, T.J., and Somers, W.P., 1968, Stage measurements at gaging stations: U.S. Geological Survey Techniques of Water-Resources Investigations, book 3, chap. A7, 28 p.

Buchanan, T.J., and Somers, W.P., 1969, Discharge measurements at gaging stations: U.S. Geological Survey Techniques of Water-Resources Investigations Report, book 3, chap. A8, 65 p.

Burcher, C.L., 2009, Using simplified watershed hydrology to define spacially explicit 'zones of influence': Hydrobiologia, v. 618, p. 149-160.

Burger, L.W., Jr., 2005, The Conservation Reserve Program in the Southeast - issues affecting wildlife habitat value, in Haufler, J.B., ed., Fish and wildlife benefits of farm bill conservation programs - 2000-2005 update: The Wildlife Society Technical Review 05-2, p. 63-92.

Charles, D.F., Knowles, C., and Davis, R.S., eds., 2002, Protocols for the analysis of algal samples collected as part of the U.S. Geological Survey National Water-Quality Assessment Program: Philadelphia, Pa., The Academy of Natural Sciences, Patrick Center for Environmental Research Report No. 02-06.

Christensen, V.G., Graham, J.L., Milligan, C.R., Pope, L.M., and Ziegler, A.C., 2006, Water quality and relation to tasteand-odor compounds in the North Fork Ninnescah River and Cheney Reservoir, south-central Kansas, 1997-2003: U.S. Geological Survey Scientific Investigations Report 2006-5095, 43 p.

Christensen, V.G., and Pope, L.M., 1997, Occurrence of dissolved solids, nutrients, atrazine, and fecal coliform bacteria during low flow in the Cheney Reservoir watershed, south-central Kansas, 1996: U.S. Geological Survey WaterResources Investigations Report 97-4153, 13 p.
Church, M., and Gilbert, R., 1975, Proglacial fluvial and lacustrine environments, glaciofluvial and glaciolacustrine sedimentation, in Jopling, A.V., and McDonald, B.C., eds., Society of Economic Paleontologists and Mineralogists Special Publications, v. 23, p. 40-100.

Clark, W.R., and Reeder, K.F., 2005, Continuous enrollment Conservation Reserve Program-factors influencing the value of agricultural buffers to wildlife conservation, in Haufler, J.B., ed., Fish and wildlife benefits of farm bill conservation programs - 2000-2005 update: The Wildlife Society Technical Review 05-2, p. 93-114.

Cuffney, T.F., 2003, User manual for the National WaterQuality Assessment Program Invertebrate Data Analysis System (IDAS) software, version 3: U.S. Geological Survey Open-File Report 03-173, 114 p.

Dodds, W.K., Jones, J.R., and Welch, E.B., 1998, Suggested classification of stream trophic state-distributions of temperate stream types by chlorophyll, total nitrogen and phosphorus: Water Research, v. 32, p.1455-1462.

Evans, C., and Davies, T.D., 1998, Causes of concentration/ discharge hysteresis and its potential as a tool for analysis of episode hydrochemistry: Water Resources Research, v. 34, no. 1, p. 129-137.

Ferrand, D.T., and Ryan, M.R., 2005, Impact of the Conservation Reserve Program on wildlife conservation in the Midwest, in Haufler, J.B., ed., Fish and wildlife benefits of farm bill conservation programs-2000-2005 update: The Wildlife Society Technical Review 05-2, p. 41-62.

Fishman, M.J., ed., 1993, Methods of analysis by the U.S. Geological Survey National Water Quality LaboratoryDetermination of inorganic and organic constituents in water and fluvial sediments: U.S. Geological Survey OpenFile Report 93-125, 217 p.

Fitzpatrick, F.A., Waite, I.R., D’Arconte, P.J., Meador, M.R., Maupin, M.A., and Gurtz, M.E., 1998, Revised methods for characterizing stream habitat in the National Water-Quality Assessment Program: U.S. Geological Survey WaterResources Investigations Report 98-4052, 67 p.

Guasch, H., Armengol, J., Marti, E., and Sabater, S., 1998, Diurnal variation in dissolved oxygen and carbon dioxide in two low-order streams: Water Resources, v. 32, no. 4, p. 1067-1074.

Guy, H.P., 1977, Laboratory theory and methods for sediment analysis: U.S. Geological Survey Techniques of WaterResources Investigations, book 5, chap. C1, 58 p.

Guy, H.P., and Norman, V.W., 1970, Field methods for measurement of fluvial sediment: U.S. Geological Survey Techniques of Water-Resources Investigations, book 3, chap. C2, 59 p. 
Haufler, J.B., ed., 2005, Fish and wildlife benefits of farm bill conservation programs-2000-2005 update: The Wildlife Society Technical Review 05-2, 205 p.

Hessen, D.O., Henriksen, A., and Smelhus, A.M., 1997, Seasonal fluctuations and diurnal oscillations in nitrate of a heathland brook: Water Resources, v. 31, no. 7, p. $1813-1817$.

Hilsenhoff, W.L., 1987, An improved biotic index of organic stream pollution: Great Lakes Entomology, v. 20, p. 31-39.

Johnson, D.H., 2005, Grassland bird use of Conservation Reserve Program fields in the Great Plains, in Haufler, J.B., ed., Fish and wildlife benefits of farm bill conservation programs - 2000-2005 update: The Wildlife Society Technical Review 05-2, p. 17-32.

Johnson, M.R., and Zelt, R.B., 2005, Protocols for mapping and characterizing land use/land cover in riparian zones: U.S. Geological Survey Open-File Report 2005-1302, 22 p.

Karr, J.R., 1981, Assessment of biotic integrity using fish communities: Fisheries, v. 6, no. 6, p. 21-27.

Karr, J.R., and Dudley, D.R., 1981, Ecological perspectives on water quality goals: Environmental Management, v. 5, p.55-68.

Karr, J.R., Heidinger, R.C., and Helmer, E.H., 1985, Sensitivity of the index of biotic integrity to changes in chlorine and ammonia levels from wastewater treatment facilities: Journal of the Water Pollution Control Federation, v. 57 , p. $912-915$.

Kennedy, E.J., 1983, Computation of continuous records of streamflow: U.S. Geological Survey Techniques of Water Resources Investigations, book 3, chap. A13, 53 p.

Kennedy, E.J., 1984, Discharge ratings at gaging stations: U.S. Geological Survey Techniques of Water-Resources Investigations, book 3, chap. A10, 59 p.

Magner, J.A., and Alexander, S.C., 1993, The Minnesota River Basin - a hydrogeologic overview: Saint Paul, Minnesota Pollution Control Agency, 21 p.

Matlock, M.D., Matlock, M.E., Storm, D.E., Smolen, M.D., and Henley, W.J., 1998, Limiting nutrient determination in lotic ecosystems using a quantitative nutrient enrichment periphytometer: Journal of the American Water Resources Association, v. 34, no. 5, p. 1141-1147.

Mayer, P.M., Reynolds, S.K., McCutchen, M.D., and Canfield, T.J., 2006, Riparian buffer width, vegetative cover, and nitrogen removal effectiveness - a review of current science and regulations: Cincinnati, Ohio, U.S. Environmental Protection Agency, EPA/600/R-05/118, 27 p.
McFarland, Anne, Kiesling, R.L., and Back, J.S., 2004, Using periphytometers to evaluate impairment due to nutrient enrichment: Stephenville, Texas Institute for Applied Environmental Research, 52 p.

Merritt, R.W., and Cummins, K.W., 1996, An introduction to the aquatic insects of North America ( $3 \mathrm{~d}$ ed.): Dubuque, Iowa, Kendall, Hunt Publishing, 862 p.

Minnesota Board of Water and Soil Resources, 2004, Minnesota River CREP fact sheet: accessed September 18, 2009, at http://www.bwsr.state.mn.us/easements/ rim/crep.pdf.

Minnesota Board of Water and Soil Resources, 2007, Status report-RIM Reserve Conservation Easements-leveraging federal funds for clean water and new wildlife habitat, February 20, 2007: accessed May 21, 2009, at http://www. bwsr.state.mn.us/news/rimstatus2007.pdf.

Moulton, S.R., Kennen, J.G., Goldstein, R.M., and Hambrook, J.A., 2002, Revised protocols for sampling algal, invertebrate, and fish communities as part of the National Water-Quality Assessment Program: U.S. Geological Survey Open-File Report 02-150, 75 p.

Moulton, S.R., II, Carter, J.L., Grotheer, S.A., Cuffney, T.F., and Short, T.M., 2000, Methods of analysis by the U.S. Geological Survey National Water Quality Laboratoryprocessing, taxonomy, and quality control of benthic macroinvertebrate samples: U.S. Geological Survey OpenFile Report 00-212, 49 p.

Natural Resources Conservation Service, 2003, U.S. General Soil Map (STATSGO2) for MN: accessed Dec. 18, 2003, at http://soildatamart.nrcs.usda.gov.

Nistor, C.J., and Church, Michael, 2005, Suspended sediment transport regime in a debris-flow gully on Vancouver Island, British Columbia: Hydrological Processes, v. 19, p. 861-885.

Odum, H.T., 1956, Primary production in flowing waters: Limnology and Oceanography, v. 1, no. 2, p. 102-117.

Odum, H.T., 1957, Primary production measurements in eleven Florida springs and a marine turtle grass community: Limnology and Oceanography, v. 2, p. 85-97.

Ojakangas, R.W., and Matsch, C.L., 1982, Minnesota's geology: Minneapolis, University of Minnesota Press, $255 \mathrm{p}$.

Olive, L.J., and Rieger, W.A., 1985, Variation in suspended sediment concentration during storms in five small catchments in southeast New South Wales: Australian Geographic Studies, v. 23, p. 38-51. 
Osborn, C.T., Llacuna, Felix, and Lisenbigler, Michael, 1995, The Conservation Reserve Program - enrollment statistics for signup periods 1-12 and fiscal years 1986-93: Washington, D.C., Economic Research Service, U.S. Department of Agriculture, Statistical Bulletin No. 925, 102 p., accessed Sept. 17, 2009, at http://www.ers.usda.gov/ publications/sb925/.

Patton, C.J., and Kryskalla, J.R., 2003, Methods of analysis by the U.S. Geological Survey National Water Quality Laboratory-Evaluation of alkaline persulfate digestion as an alternative to Kjeldahl digestion for determination of total and dissolved nitrogen and phosphorus in water, Water-Resources Investigations Report 03-4174, 33 p.

Payne, G.A., 1994, Sources and transport of sediment, nutrients, and oxygen-demanding substances in the Minnesota River Basin, 1989-92: U.S. Geological Survey Water-Resources Investigations Report 93-4232, $71 \mathrm{p}$.

Pennak, R.W., 1989, Freshwater invertebrates of the United States (3d ed.): New York, Wiley, 628 p.

Reynolds, R.E., 2005, The Conservation Reserve Program and duck production in the U.S. Prairie Pothole Region, in Haufler, J.B., ed., Fish and wildlife benefits of farm bill conservation programs - 2000-2005 update: The Wildlife Society Technical Review 05-2, p. 33-40.

Sokal, R.R., and Rohlf, F.J., 1995, Beometry-the principles and practice of statistics in biological research, 3d edition: New York, W.H. Freeman and Co., ISBN no $0-7167-2411-1,887 \mathrm{p}$.

Stark, James, 1997, Causes of variations in water quality and aquatic ecology in rivers of the Upper Mississippi River Basin, Minnesota and Wisconsin: U.S. Geological Survey Fact Sheet 96-249, 4 p.

Stark, J.R., Andrews, W.J., Fallon, J.D., Fong, A.L., Goldstein, R.M., Hanson, P.E., and Kroening, S.E., 1996, Waterquality assessment of part of the Upper Mississippi River Basin, Minnesota and Wisconsin-environmental setting and study design: U.S. Geological Survey Water-Resources Investigations Report 96-4098, 62 p.

Stevenson, R.J., Bothwell, M.L., and Lowe, R.L., 1996, Algal ecology, freshwater benthic ecosystems: San Diego, Calif., Academic Press, 753 p.

Stewart, Steven, Gemill, Eldon, and Pentz, Nancy, 2006, An evaluation of the effectiveness of urban riparian forest buffers: Alexandria, Va., Water Environment Research Foundation, variously paged.

Tibco Spotfire S+ 8.1, 2008, Guide to statistics (v. 1): TIBCO Software, Inc., 718 p.
Tomer, M.D., Meek, D.W., Jaynes, D.B., and Hatfield, J.L., 2003, Evaluation of nitrate nitrogen fluxes from a tile-drained watershed in central Iowa: Journal of Environmental Quality, v. 32, p. 642-653.

Tornes, L.H., 1986, Suspended sediment in Minnesota streams: U.S. Geological Survey Water-Resources Investigations Report 85-4312, 33 p.

University of Minnesota, 2009, Minnesota River Basin precipitation patterns: accessed May 21, 2009, at http:// www.soils.umn.edu/research/mn-river/img/wqfig5.gif.

University of Minnesota, 2009, Planning an agricultural subsurface drainage system: accessed Sept. 21, 2009, at http://www.extension.umn.edu/distribution/cropsystems/ DC7685.html.

U.S. Department of Agriculture, 2001, CRP Note 105, Farmable Wetland Pilot (FWP) Program eligibility: U.S. Department of Agriculture Natural Resource Conservation Service, accessed June 17, 2009, at http://www.mn.nrcs. usda.gov/technical/ecs/agron/crp/notes/105.pdf.

U.S. Department of Agriculture, National Agricultural Statistics Service, 2002, 2002 census of agriculture: U.S. Bureau of Census, accessed January 16, 2006, at http:// www.nass.usda.gov/census/census02/volume1.htm.

U.S. Department of Agriculture, 2004, The Conservation Reserve Program - economic implications for rural America: Agricultural Economic Report Number 834, 106 p.

U.S. Department of Agriculture, 2007a, CRP Note 117, FSA Conservation Message \#07-353: U.S. Department of Agriculture Natural Resource Conservation Service, accessed June 17, 2009, at http://www.mn.nrcs.usda.gov/ technical/ecs/agron/crp/notes/117.pdf.

U.S. Department of Agriculture, 2007b, Documents of eligibility and suitability for filter strip: U.S. Department of Agriculture Natural Resource Conservation Service, accessed June 17, 2009, at http://www.mn.nrcs.usda.gov/ technical/ecs/agron/crp/Eligibility\%20Docs/CP21 crep.doc.

U.S. Environmental Protection Agency, 2008, Biological indicators of watershed health: accessed Aug. 2008 at http:// www.epa.gov/bioindicators/html/invertebrate.html.

U.S. Geological Survey, 2003, National Land Cover Database 2001: accessed Jan. 21, 2009, at http://www.mrlc.gov/.

U.S. Geological Survey, 2007, Water-resources data for the United States-water year 2006: Water Data Report WDR-US-2006, accessed Oct. 6, 2009, at http://wdr.water. usgs.gov/wy2006/search.jsp. 
Wagner, R.J., Boulger, R.W., Jr., Oblinger, C.J., and Smith, B.A., 2006, Guidelines and standard procedures for continuous water-quality monitors - station operation, record computation, and data reporting: U.S. Geological Survey Techniques and Methods 1-D3, 51 p., plus 8 attachments, accessed April 10, 2006, at http://pubs.water. usgs.gov/tm $1 \mathrm{~d} 3$.

Walling, D.E., 1974, Suspended sediment and solute yields from a small catchment prior to urbanization, in Gregory, K.E., and Walling D.E., eds., Fluvial processes in instrumental watersheds: Institute of British Geographers, Special Publication 6, p. 169-192.

Walling, D.E., 1978, Suspended sediment and solute response characteristics of the River Exe, Devon, England, in Davidson-Arnott, R., and Nickling, W., eds., Research in fluvial systems: Norwich, United Kingdom, Geoabstracts, p. 169-197.

Walling, D.E., and Foster, I.D.L., 1975, Variations in the natural chemical concentration of river water during flood flows, and the lag effect-some further comments: Journal of Hydrology, v. 26, p. 237-244.

Walling, D.E., and Webb, B.W., 1981, The reliability of suspended load data - erosion and sediment transport measurement, in Proceedings of Florence Symposium: Wallingford, United Kingdom, IAHS Press, IAHS Publication 133, p. 177-194.

Wilcox, R.R., 1997, Introduction to robust estimation and hypothesis testing: San Diego, Academic Press.
Wilde, F.D., and Radke, D.B., eds., 1998, Field measurements, in National field manual for the collection of water-quality data: U.S. Geological Survey Techniques of WaterResources Investigations, book 9, chap. A6, p. 3-20.

Wilson, B., Burt, E., Oduro, P., Headrick, M., AbuLaban, A., Brown, J., and Brooks, E., 1997, Minnesota River surface tile inlet research-modeling component: Saint Paul, Final report to the Legislative Commission on Minnesota Resources, $70 \mathrm{p}$.

Winterstein, T.A., Payne, G.A., Miller, R.A., and Stark, J.R., 1993, Selected basin characteristics and water-quality data for the Minnesota River Basin: U.S. Geological Survey Open-File Report 93-164, 100 p.

Wise, D.R., Zuroske, M.L., Carpenter, K.D., and Kiesling, R.L., 2009, Assessment of eutrophication in the Lower Yakima River Basin, Washington, 2004-07: U.S. Geological Survey Scientific Investigations Report 2009-5078, 108 p.

Wood, P. A., 1977, Controls of variation in suspended sediment concentration in the River Rother, West Sussex, England: Sedimentology, v. 24, p. 437-445.

Wright, S., and Tidd, W.M., 1933, Summary of limnological investigations in western Lake Erie in 1929 and 1930: Transactions of the American Fisheries Society, v. 63, p. 271-285.

ZumBerge, J.R., Perry, J.A., and Lee, K.E., 2003, Influence of local riparian cover and watershed runoff potential on invertebrate communities in agricultural streams in the Minnesota River Basin: U.S. Geological Survey WaterResources Investigations Report 03-4068, 13 p. 
Appendix 1. Algal Species Composition, Density, and Biovolume for Samples Collected from Chetomba Creek, West Fork Beaver Creek, and South Branch Rush River, August 2006 and July 2007 


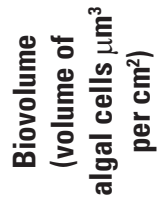

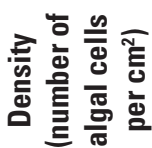

든

苛

ฮี

बำ$$
\text { गे }
$$$$
\infty
$$ 


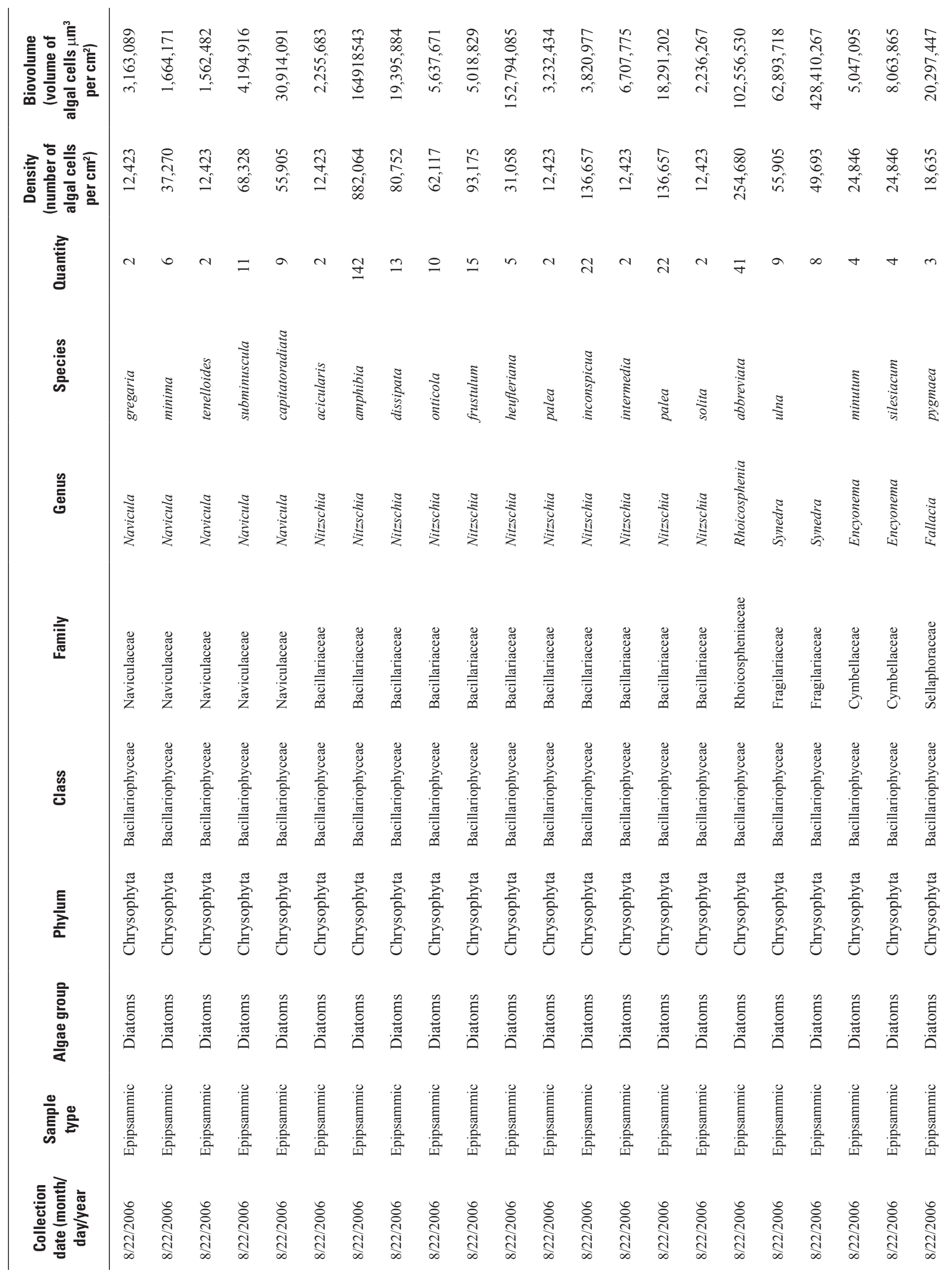




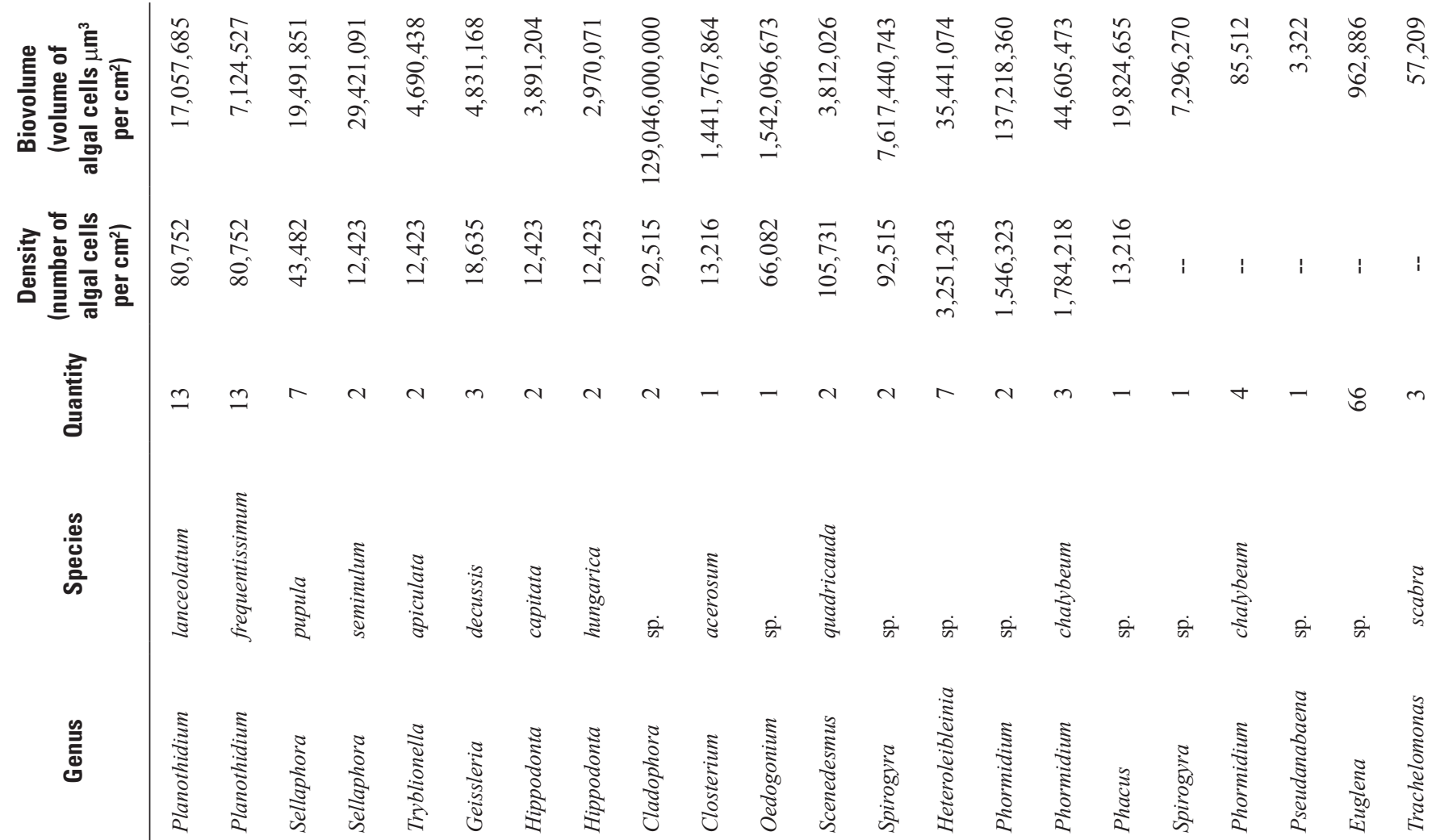
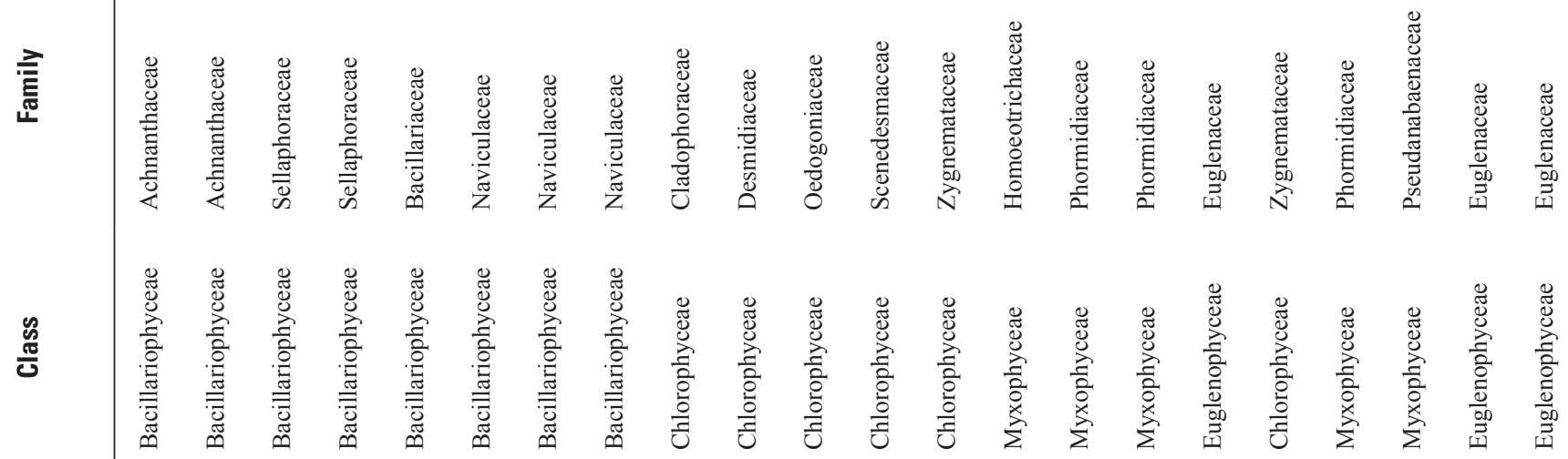

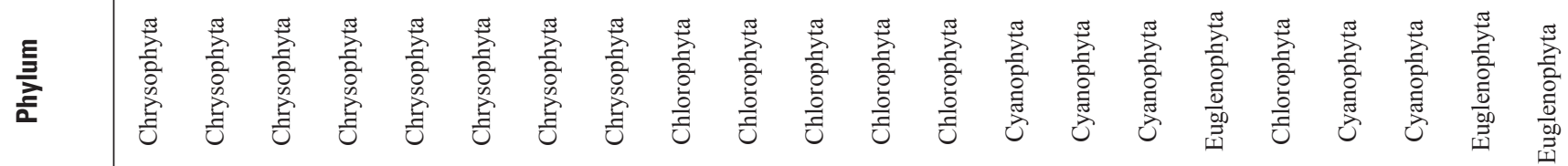

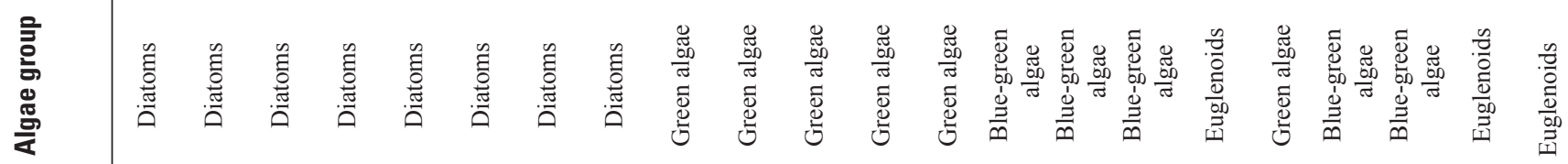

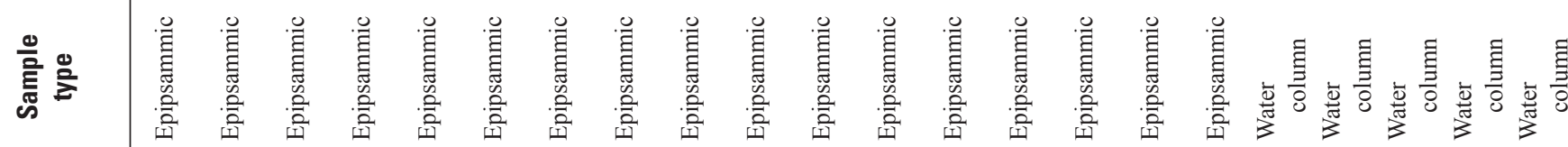

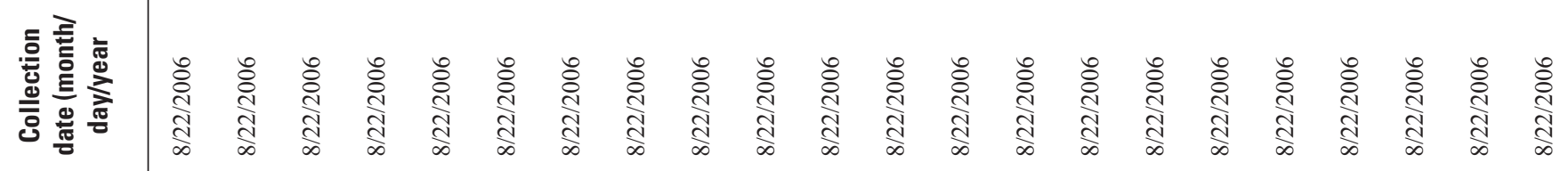




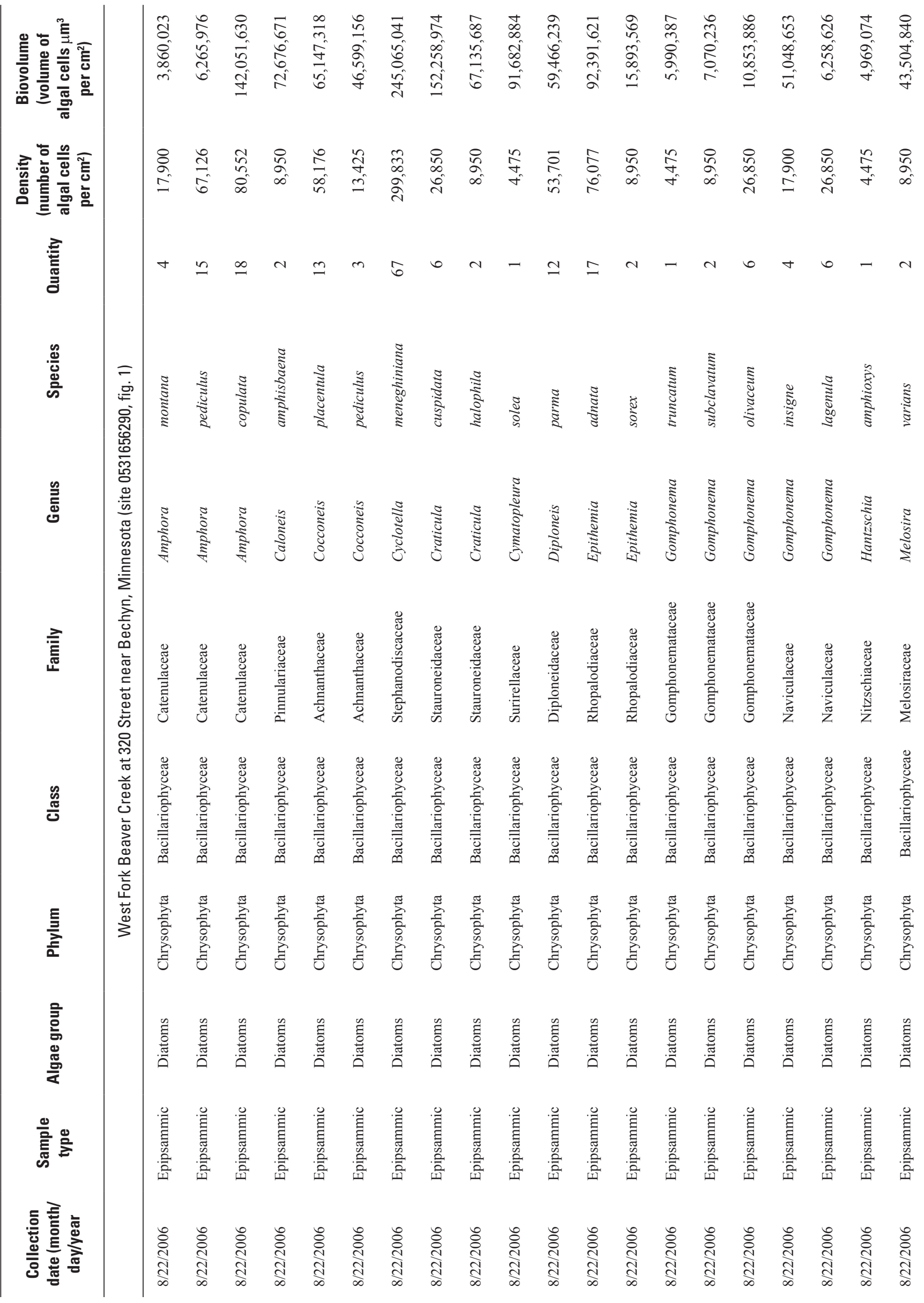




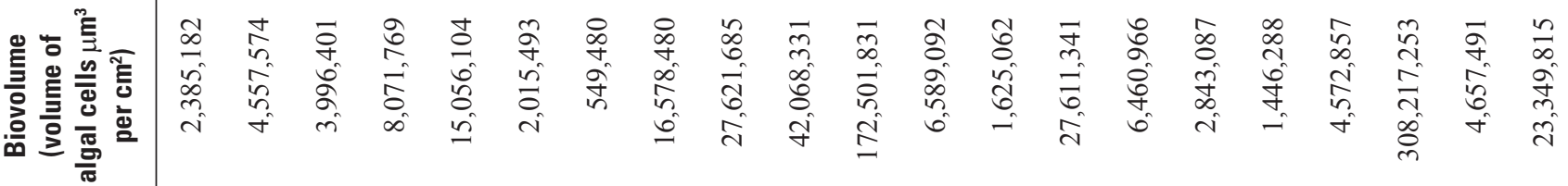

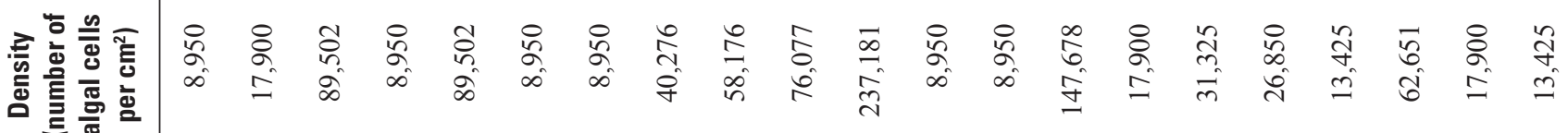
垔

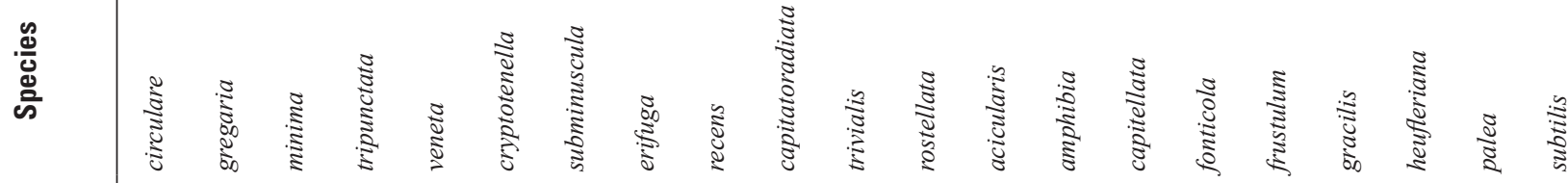
$\stackrel{\varphi}{\bar{\Xi}}$

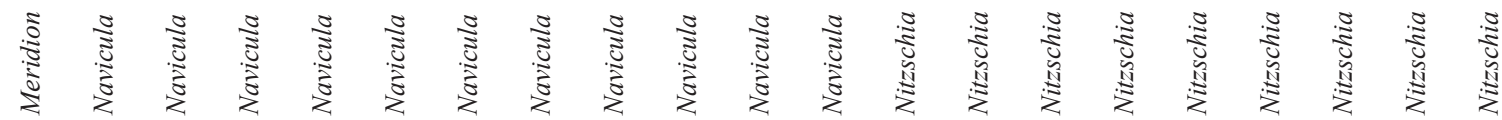

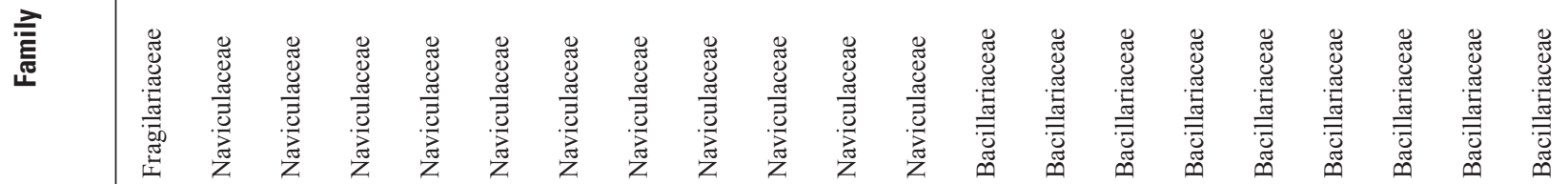

$\underset{\mathscr{C}}{\frac{\mathscr{C}}{6}}$

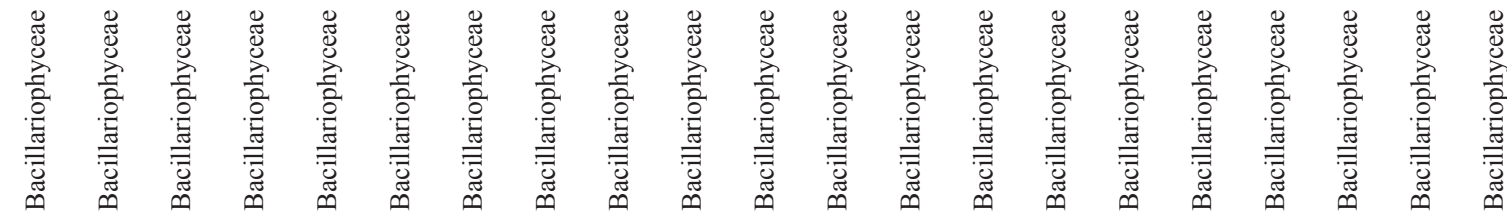

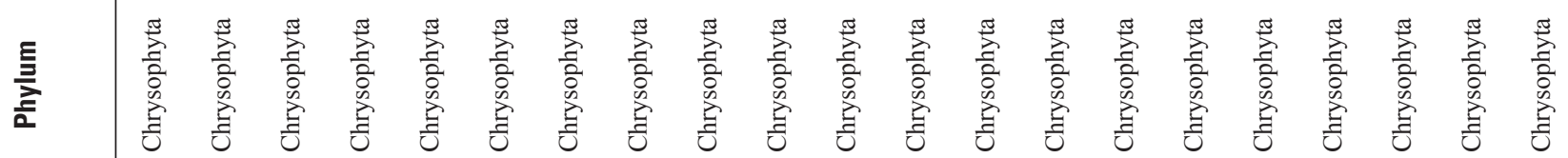

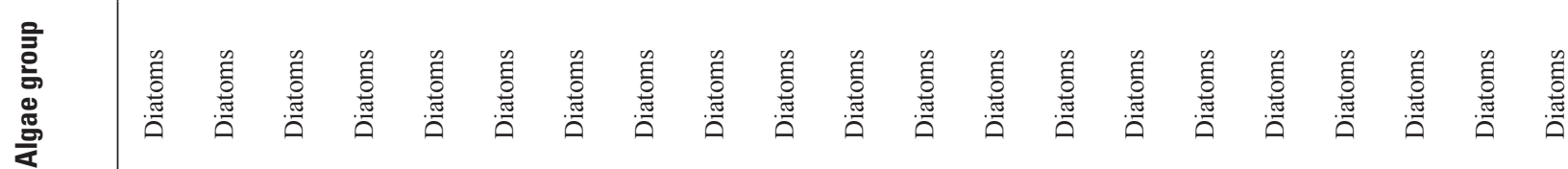

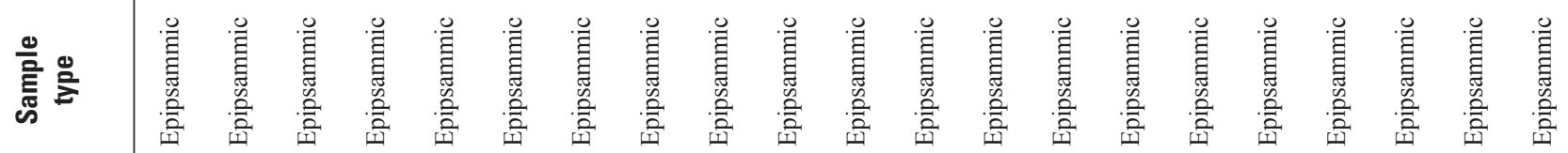

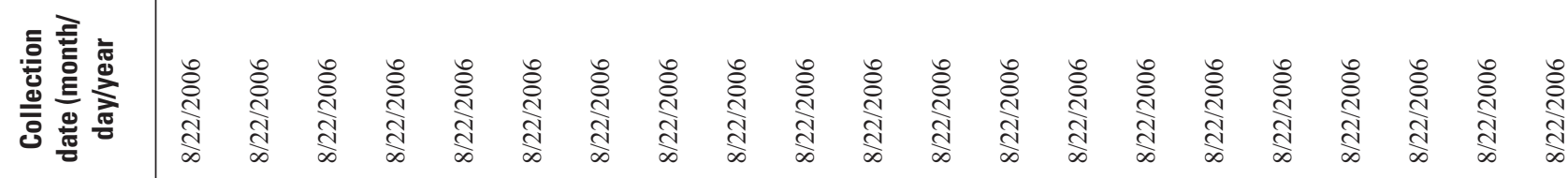




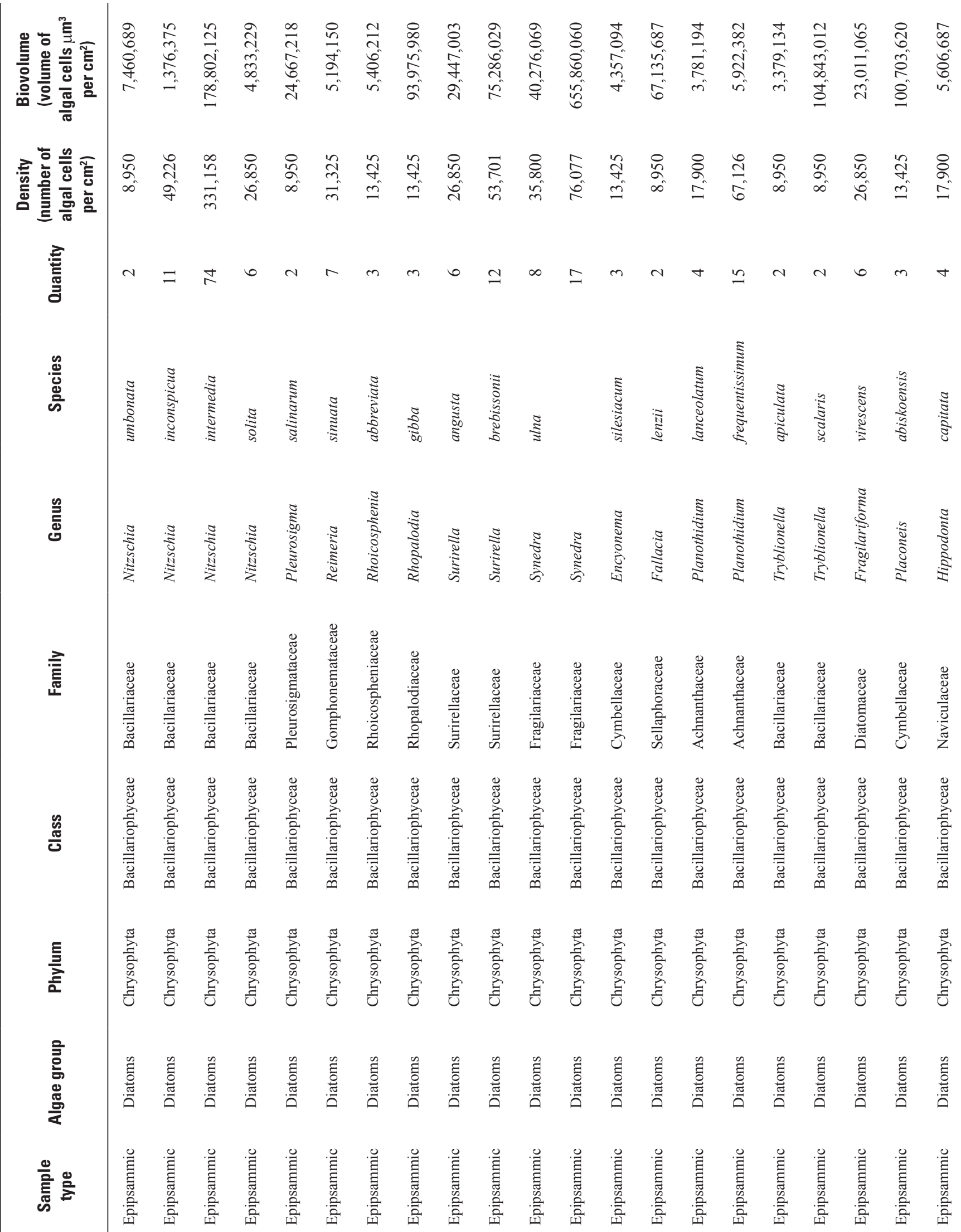

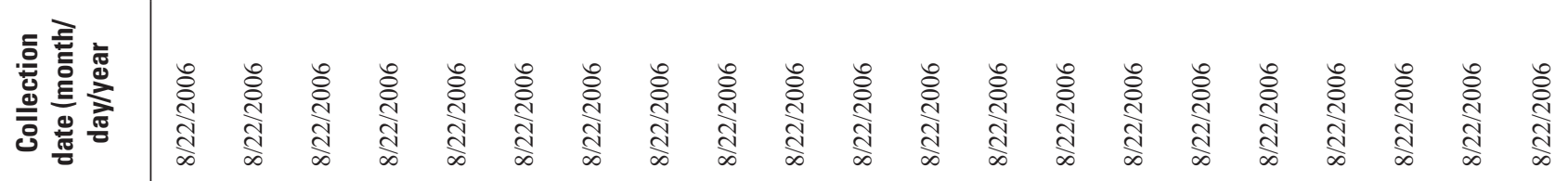




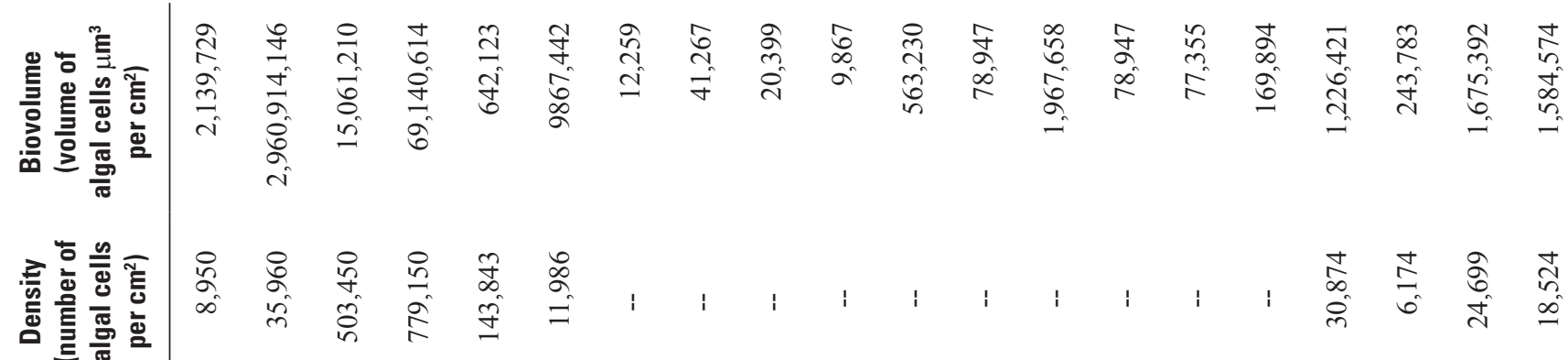

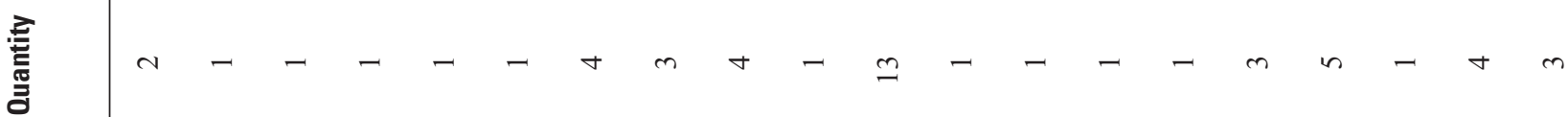

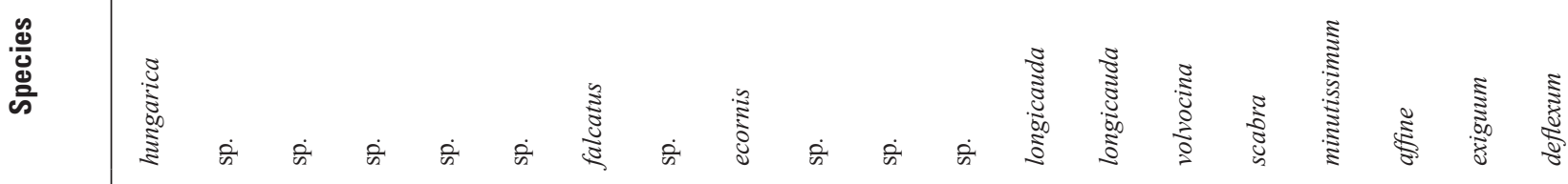
$1\|1\| 1\|\| 111\|1\|$

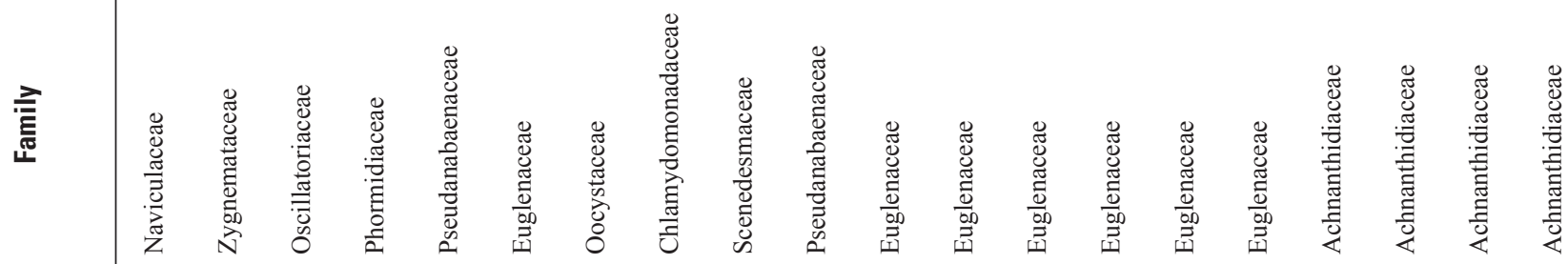

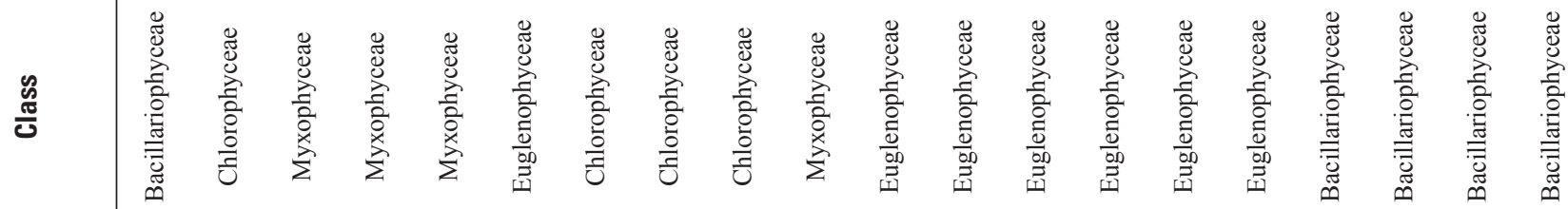
!

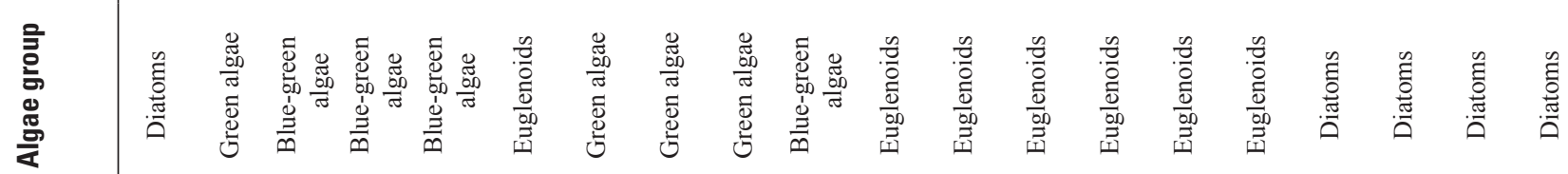

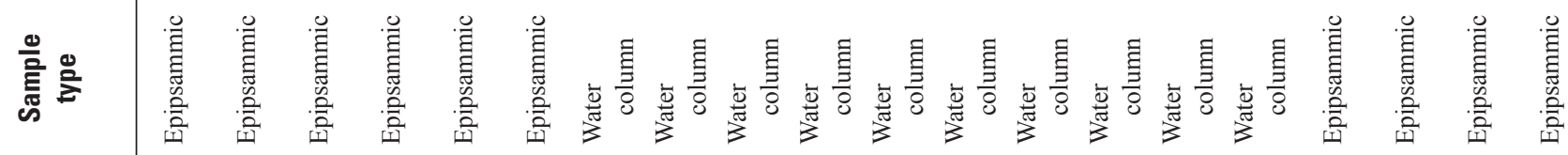
min 


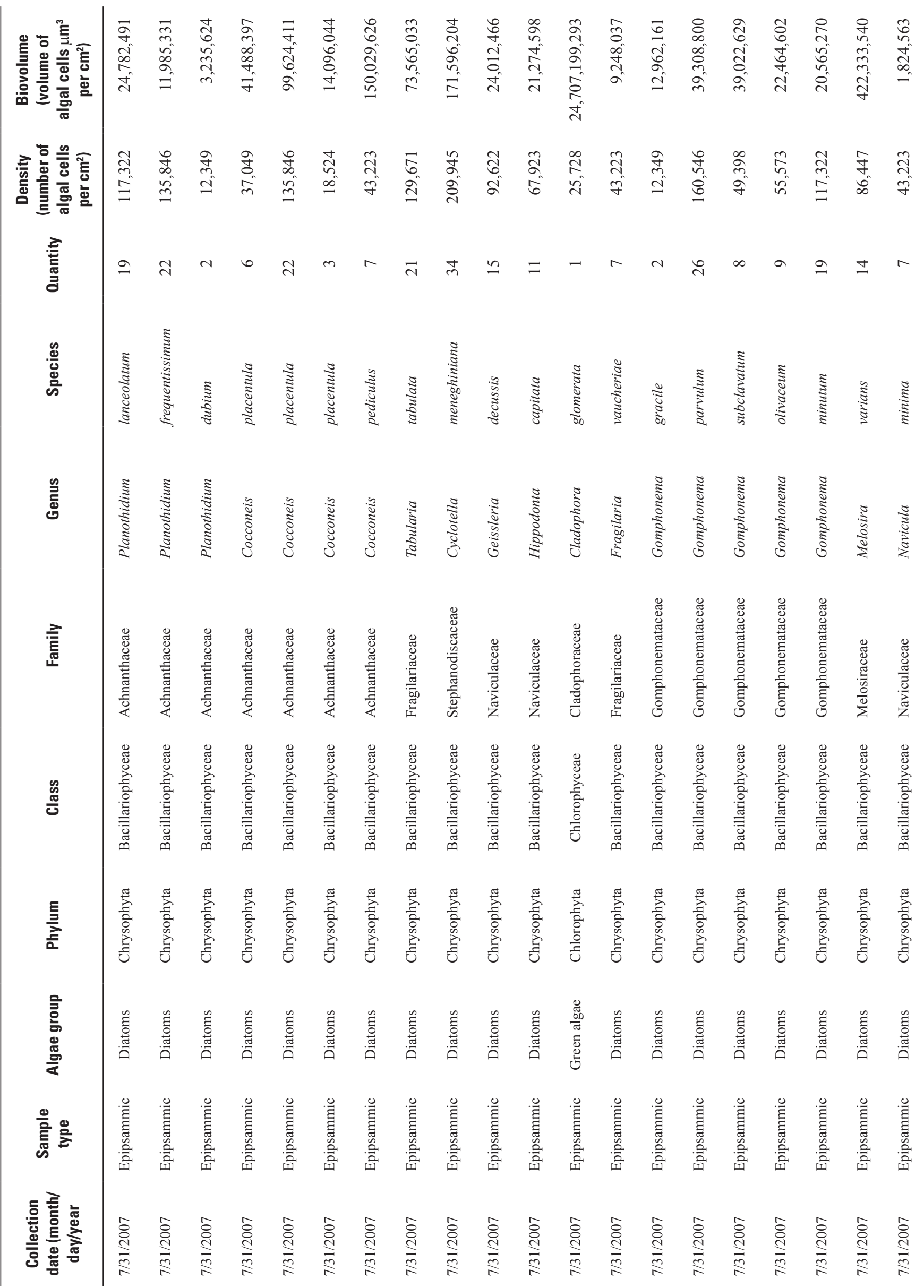




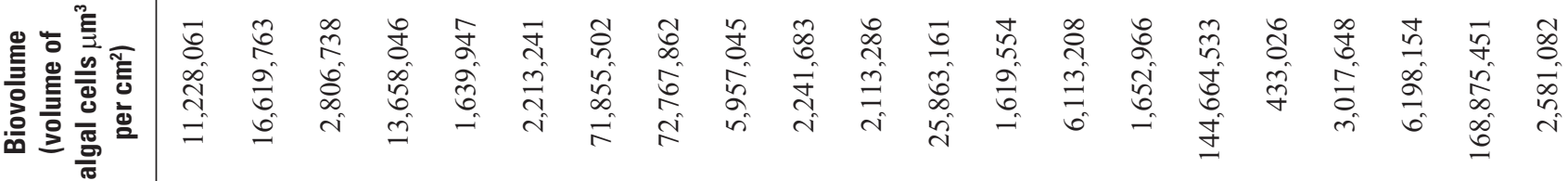

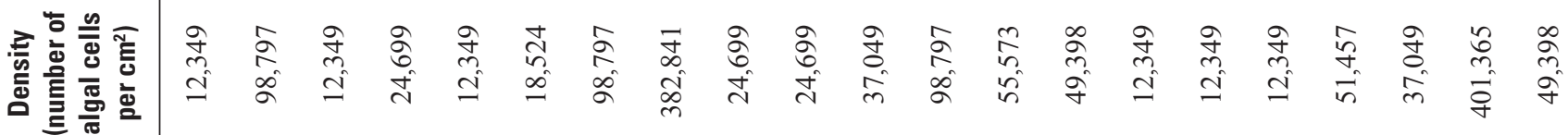
告

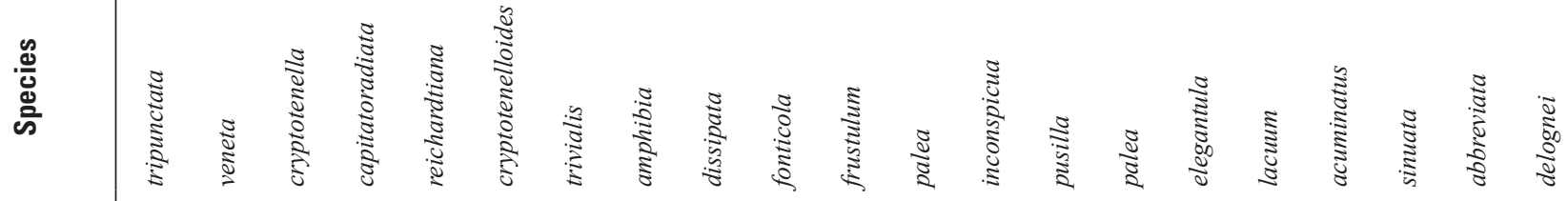

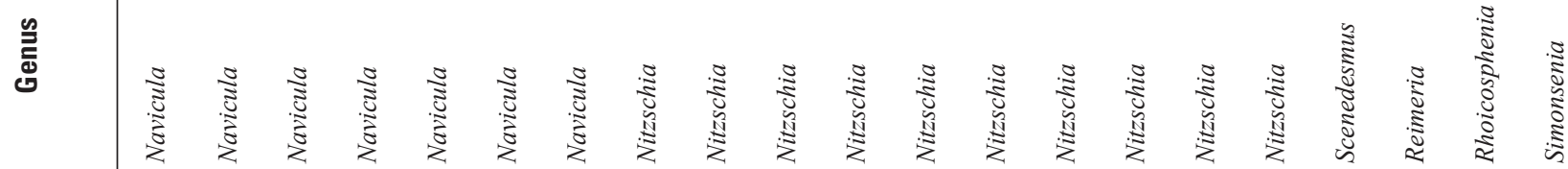

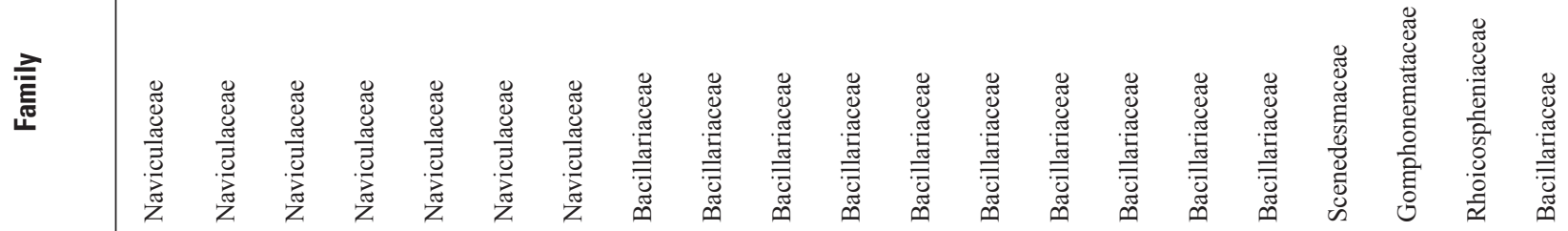

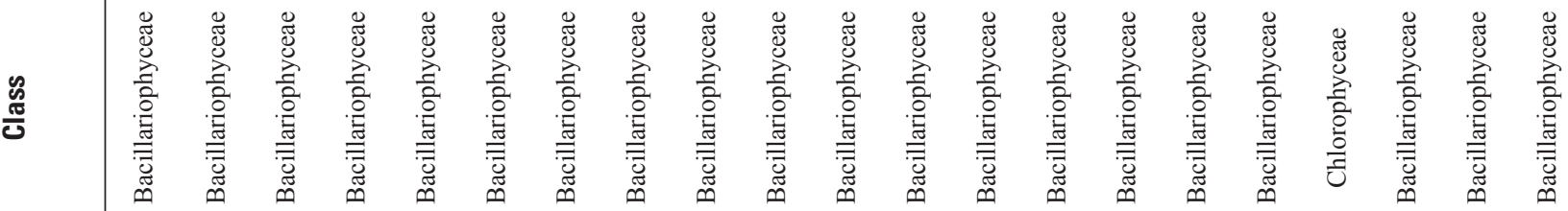

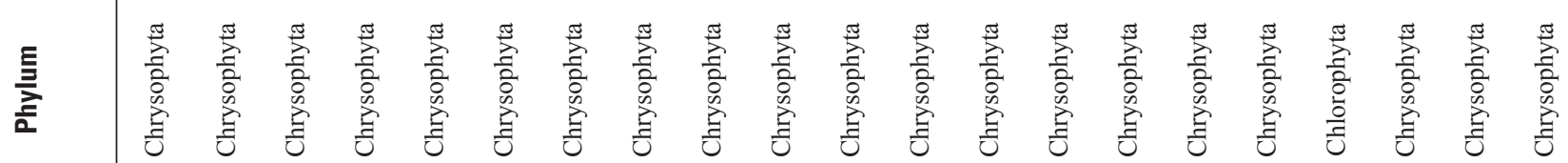

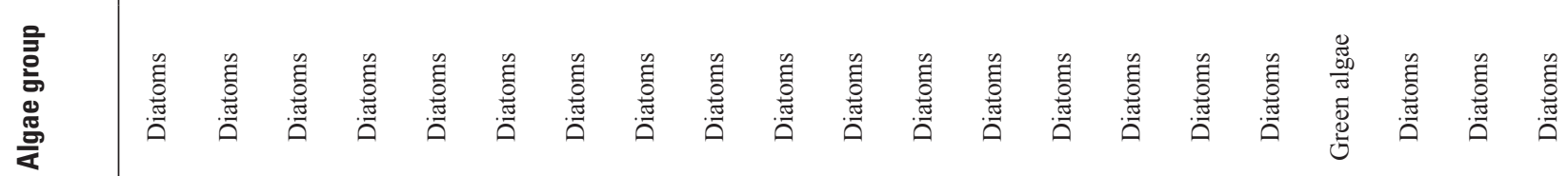

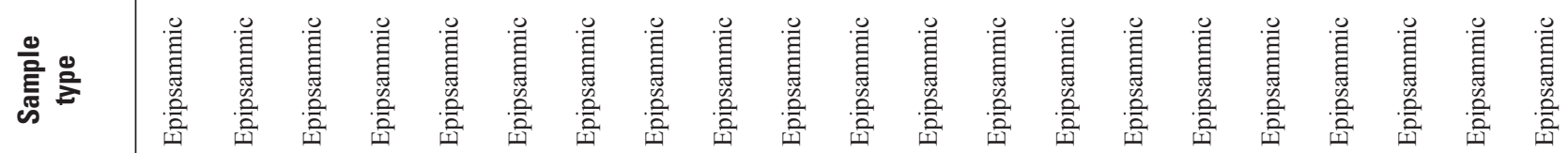

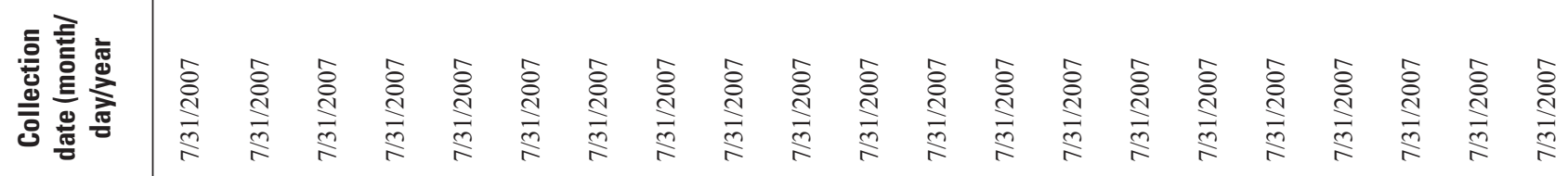









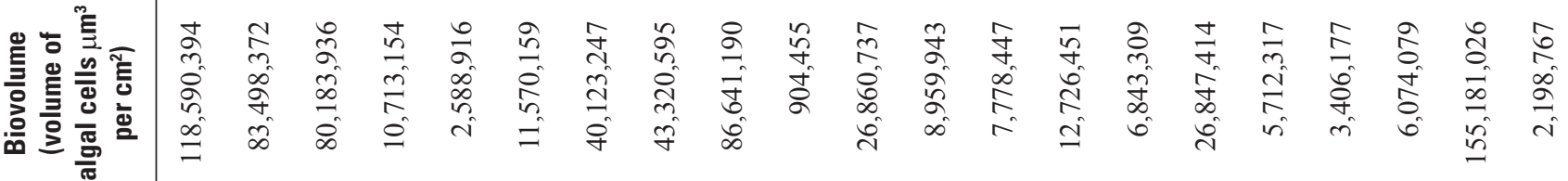

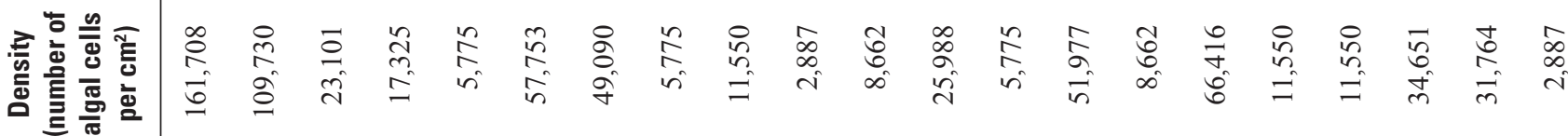

昰

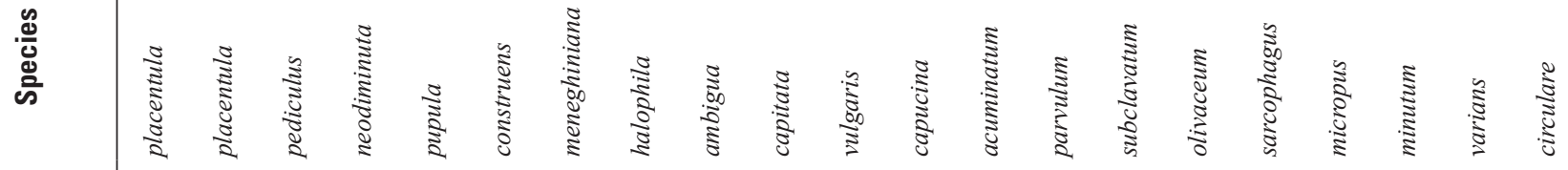

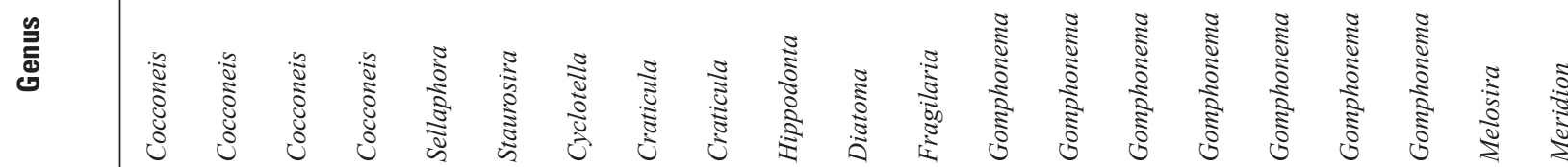

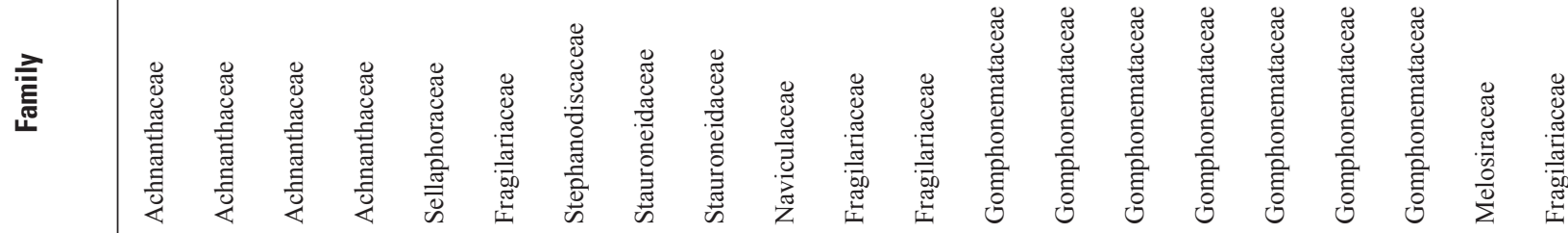

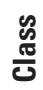

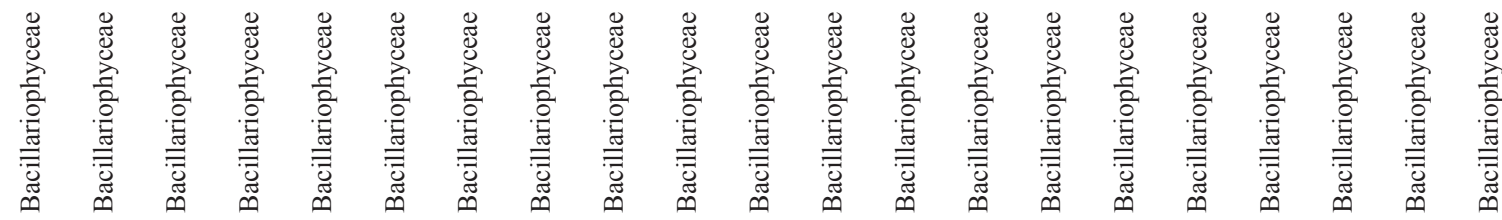

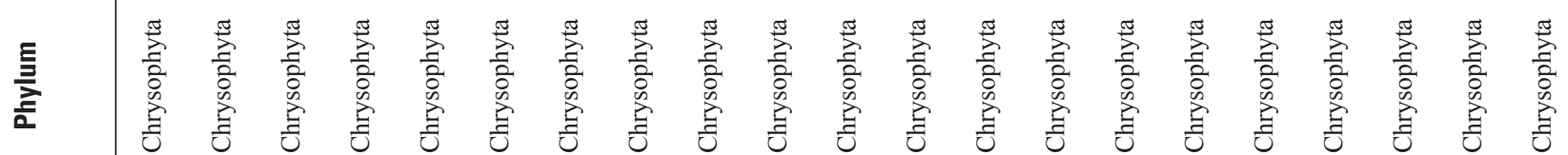

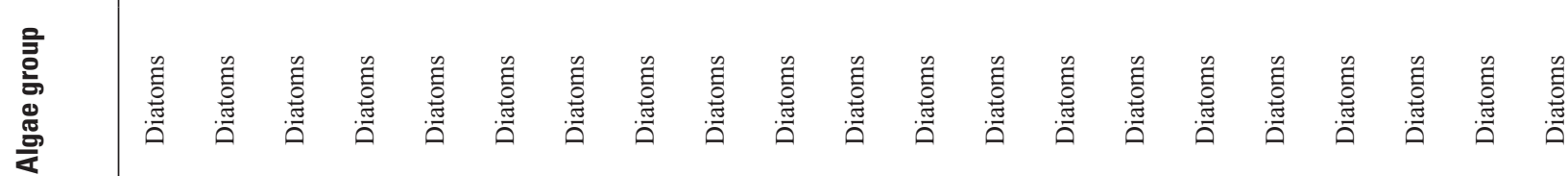

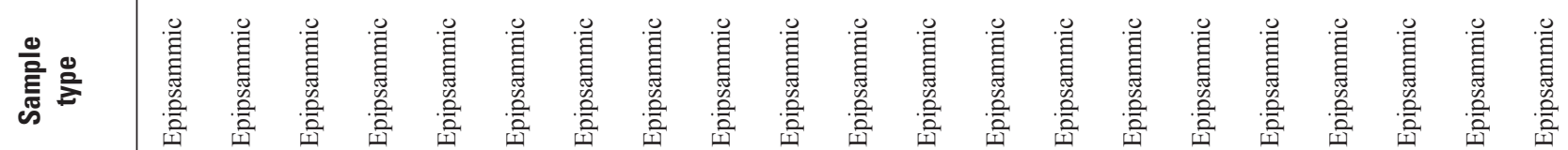

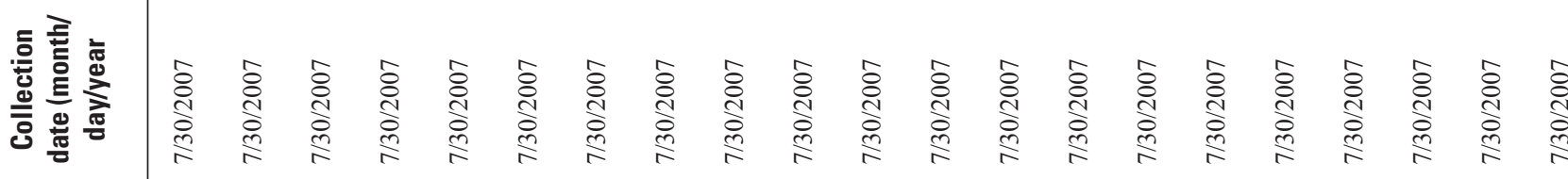




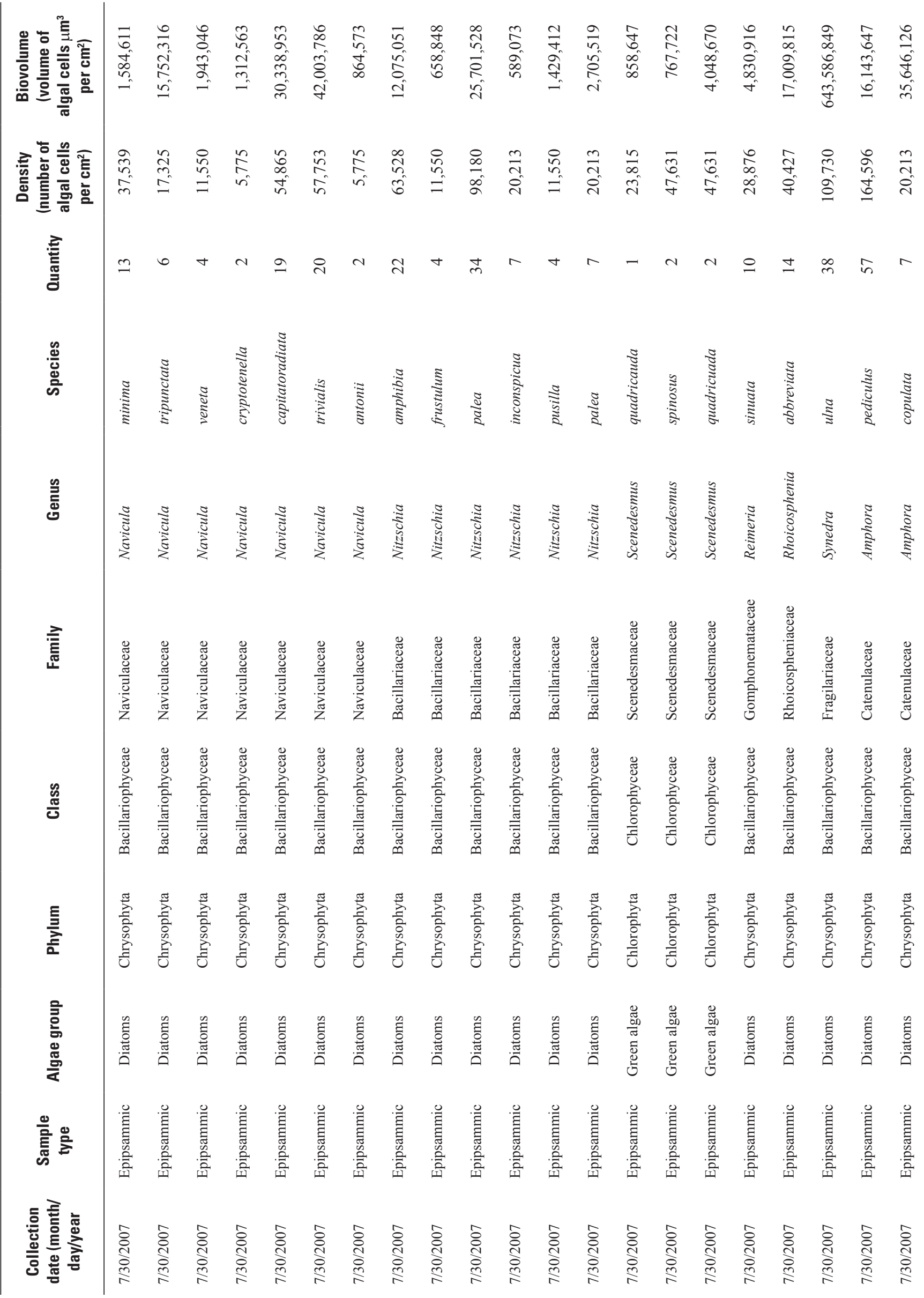




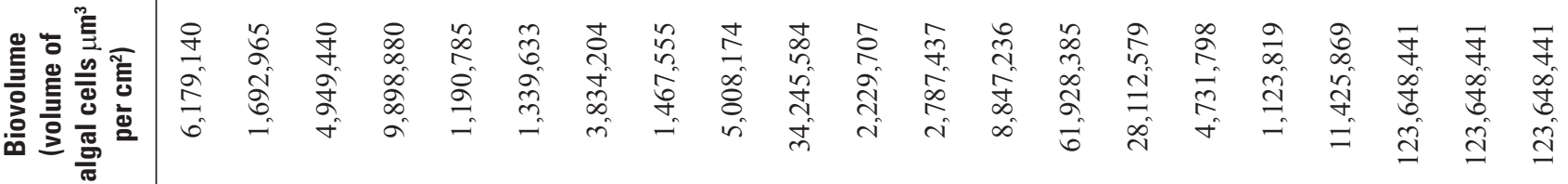

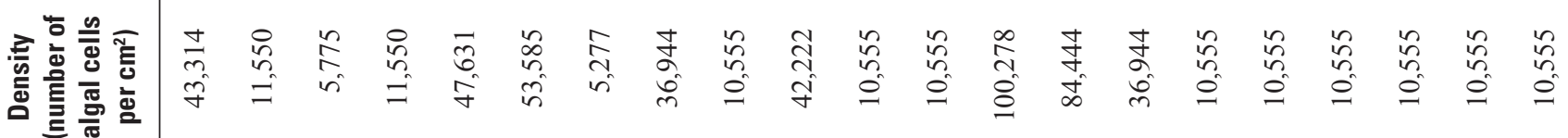

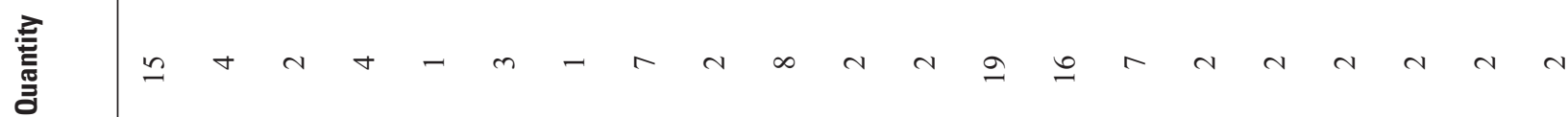
\|\|\|\|\|\|\|\|\|\|$\|$ $1 / 111111111111111$
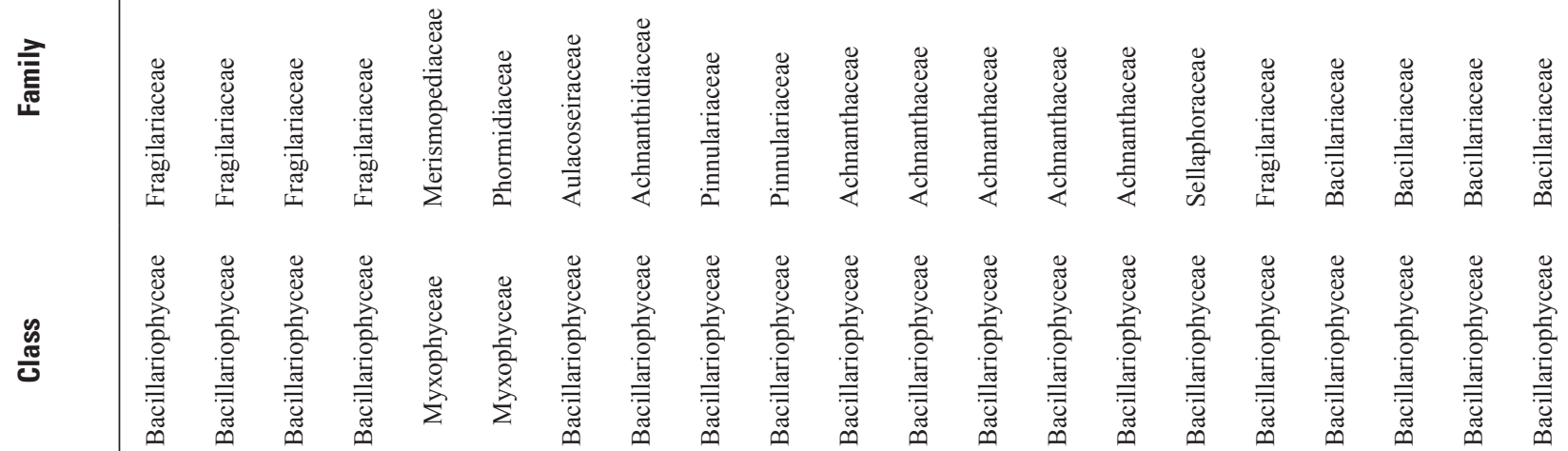

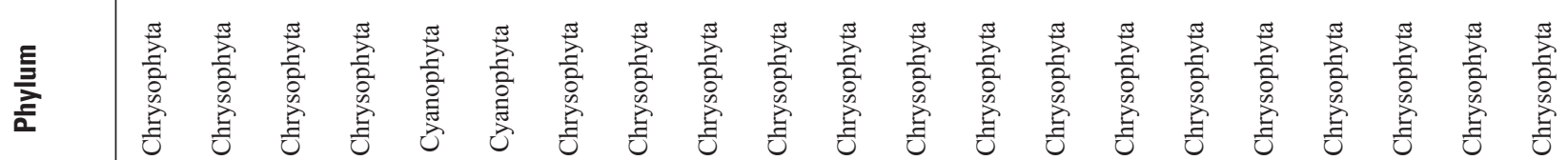

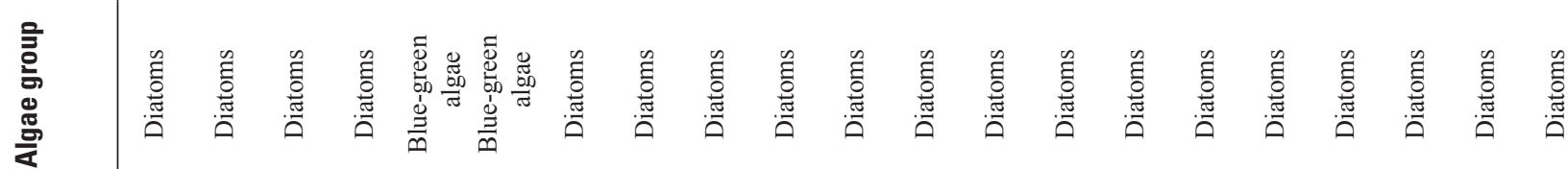

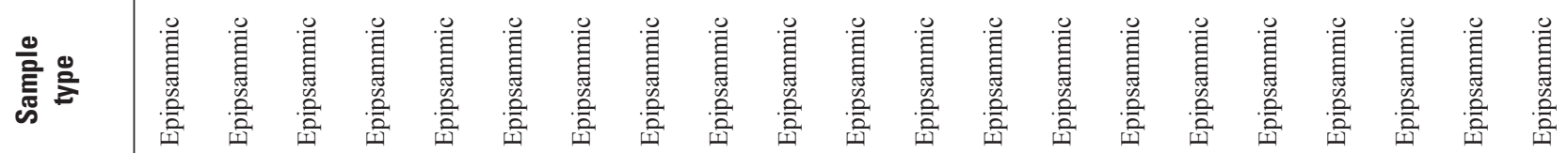

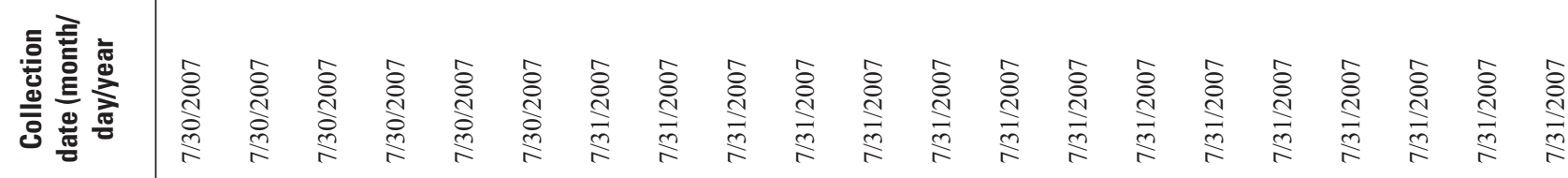




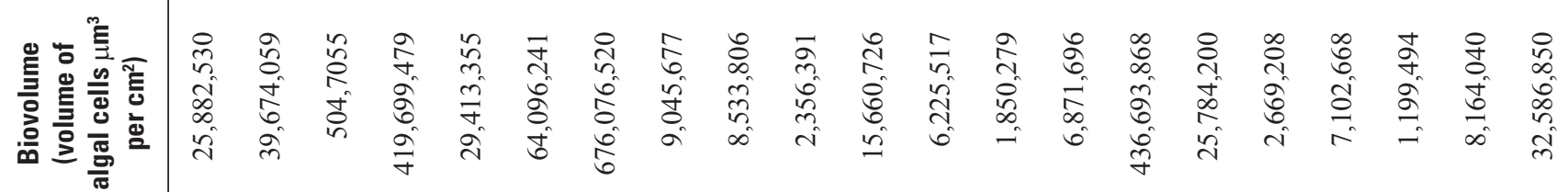

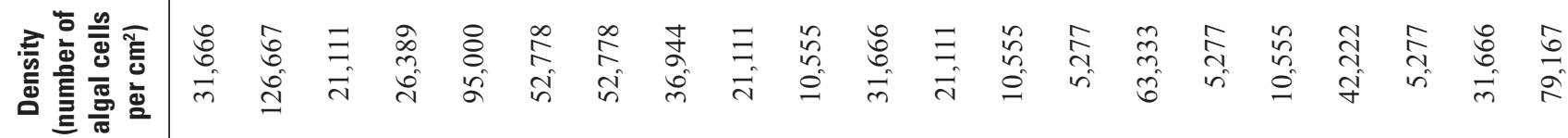

急

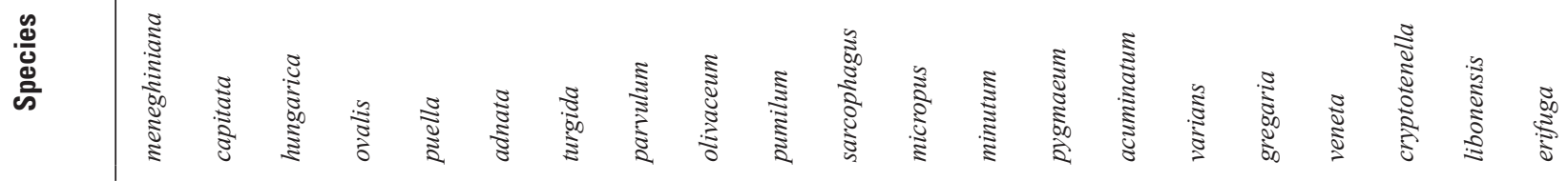

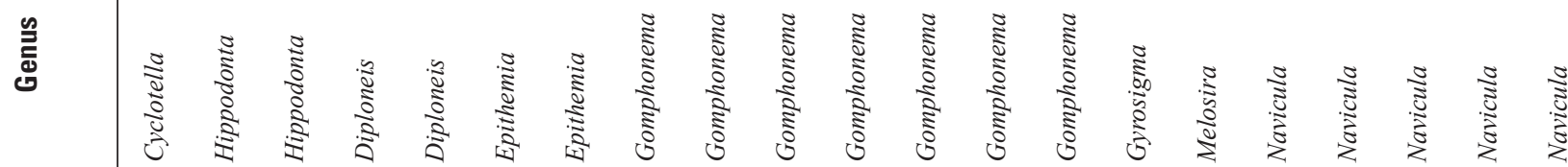

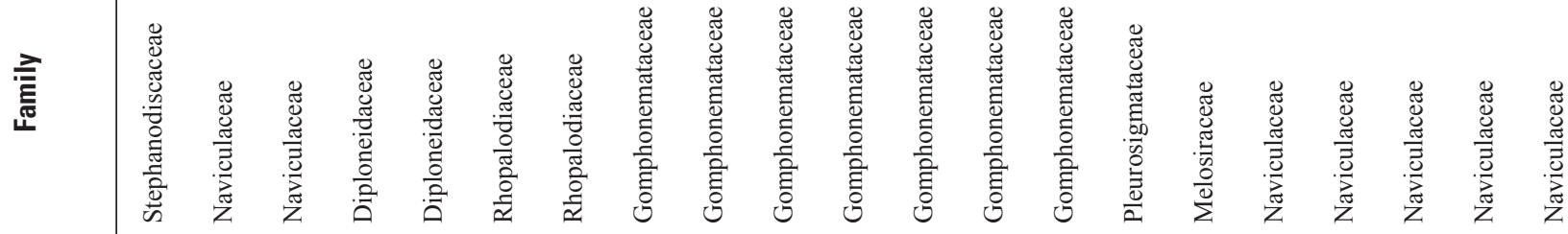

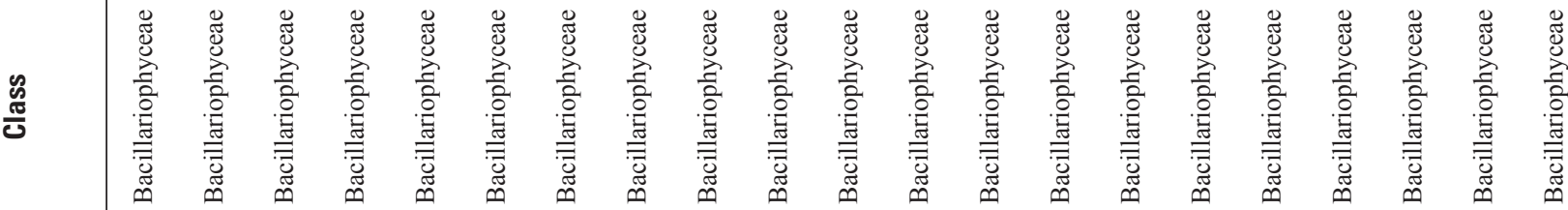

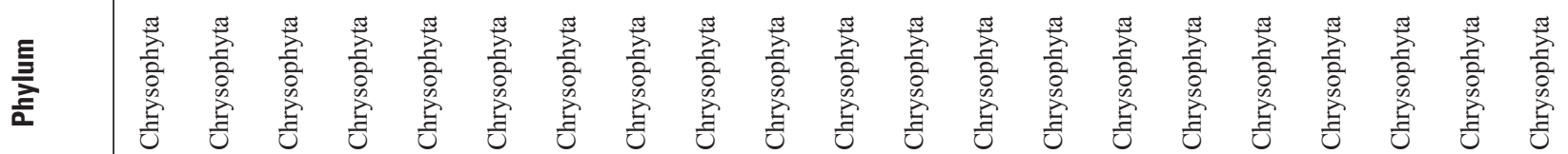

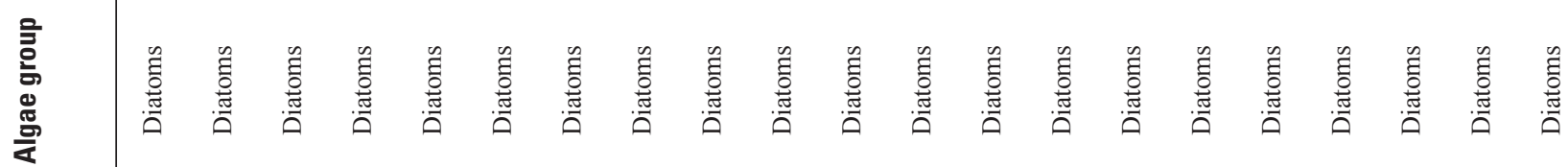

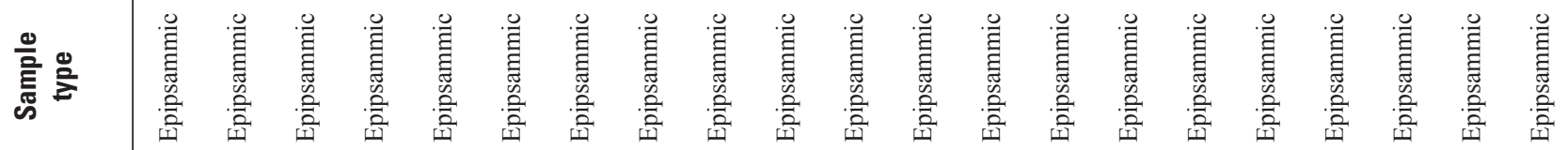

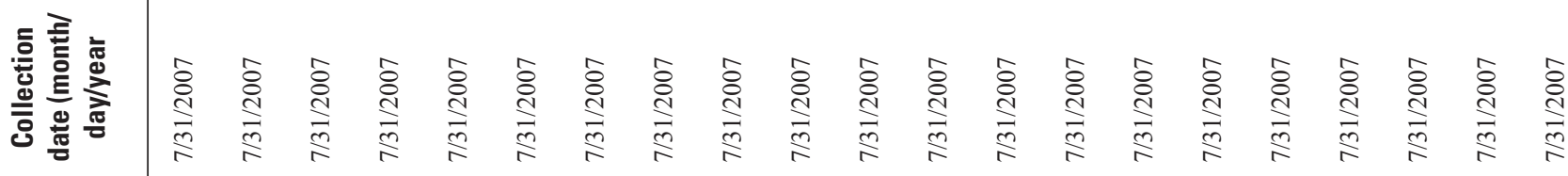




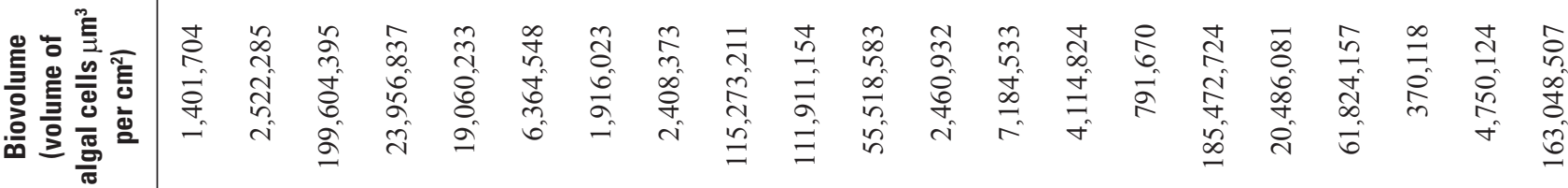

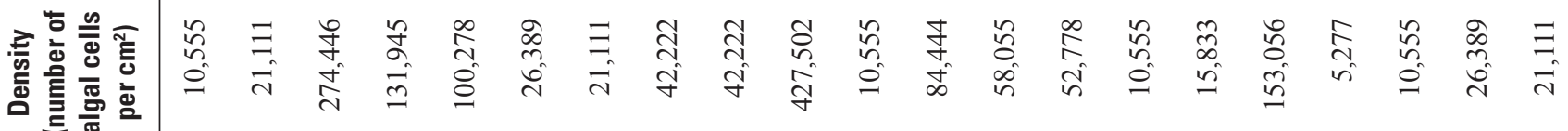

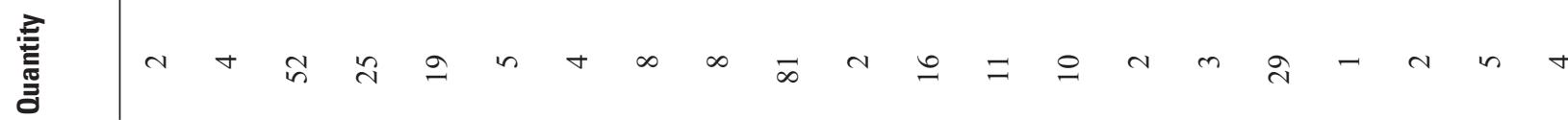

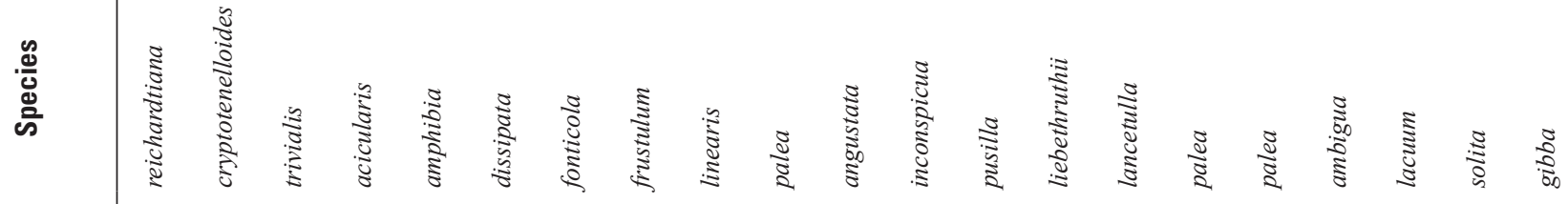

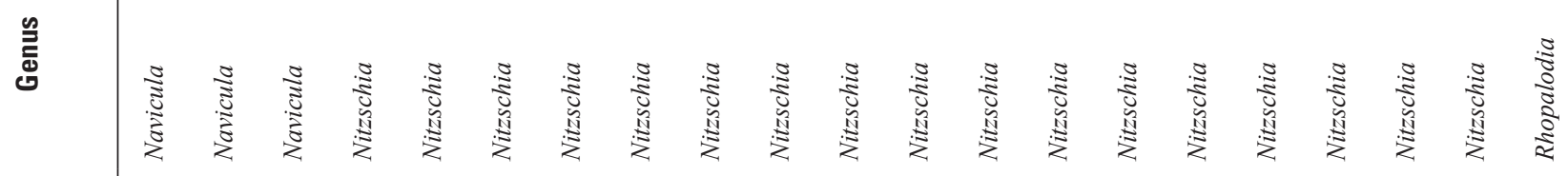

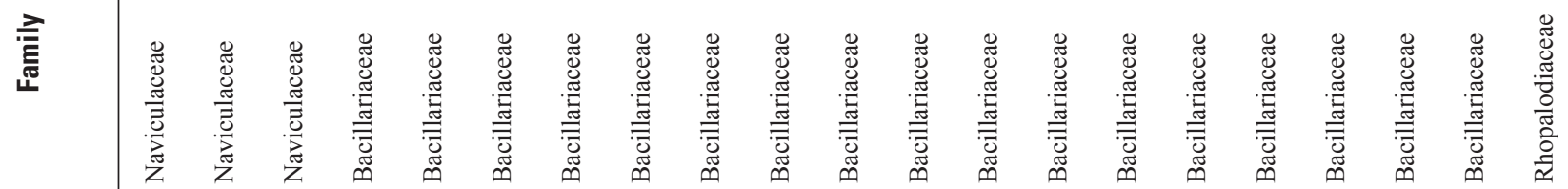

$\mathscr{8}$
$\frac{0}{U}$
$\frac{\pi}{U}$

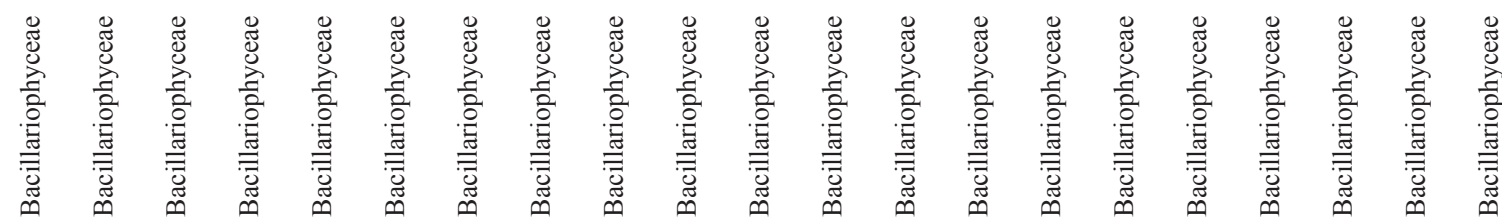

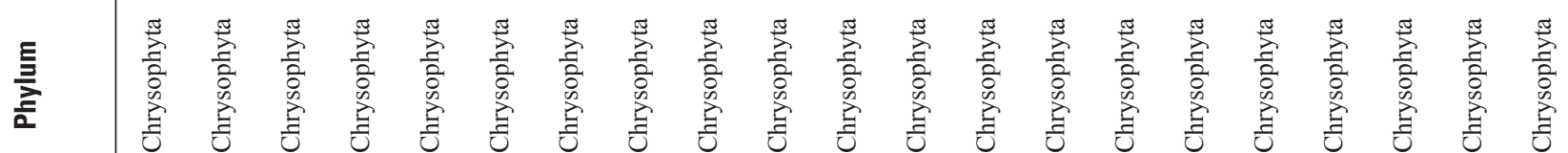

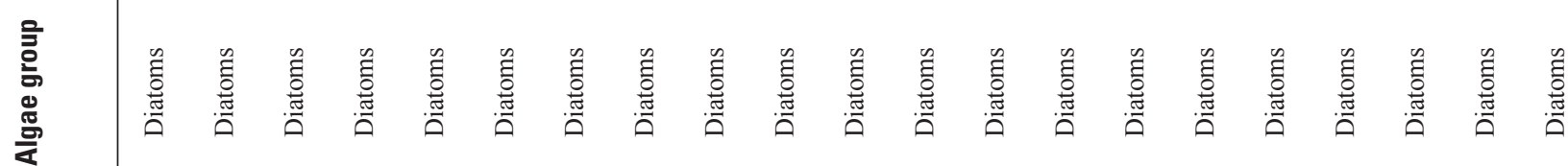

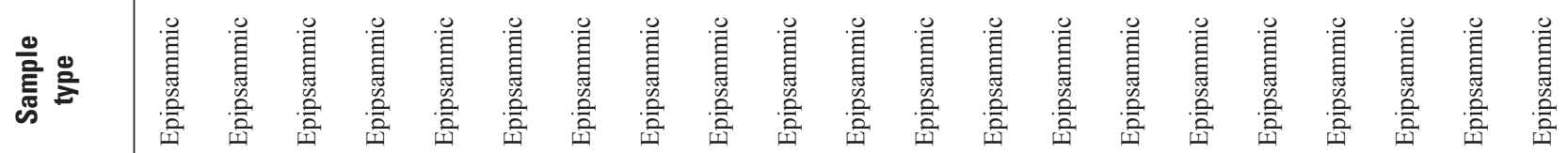

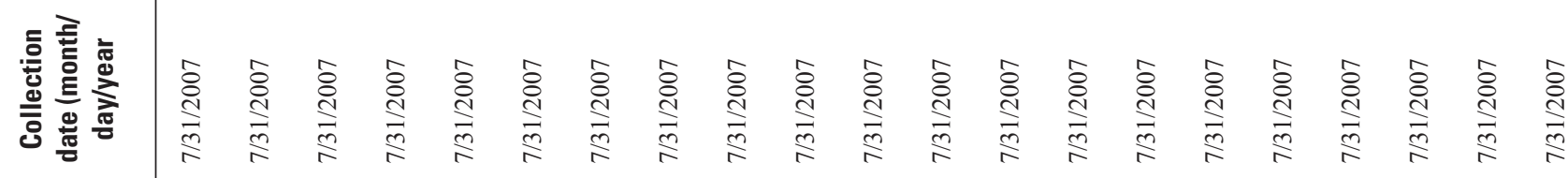




\begin{tabular}{|c|c|c|c|c|c|c|c|c|c|c|c|c|c|c|c|c|c|c|c|c|c|}
\hline 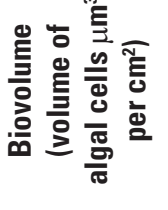 & 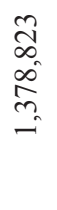 & 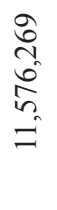 & 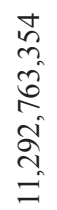 & $\begin{array}{l}\stackrel{P}{2} \\
\text { m } \\
0 \\
n \\
n \\
n\end{array}$ & $\begin{array}{l}\frac{0}{n} \\
\frac{0}{0} \\
\frac{0}{6}\end{array}$ & $\begin{array}{l}\vec{b} \\
+ \\
2 \\
n \\
n \\
n\end{array}$ & 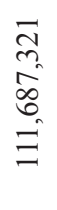 & $\begin{array}{l}\text { d } \\
\text { rn } \\
\hat{\delta} \\
\text { n. } \\
\text { ñ }\end{array}$ & $\begin{array}{l}\text { ूे } \\
\text { ळे } \\
\text { ठ }\end{array}$ & 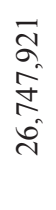 & $\begin{array}{l}\frac{\infty}{+} \\
\stackrel{2}{\hat{n}} \\
\frac{0}{0}\end{array}$ & & $\begin{array}{l}\stackrel{0}{\pi} \\
\text { î } \\
\text { ri }\end{array}$ & $\begin{array}{l}\text { Dे } \\
\infty \\
\infty \\
\infty \\
\text { in }\end{array}$ & $\begin{array}{l}0 \\
\infty \\
i n \\
\hat{0} \\
0 \\
\infty\end{array}$ & 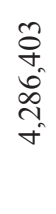 & $\begin{array}{l}0 \\
+ \\
\infty \\
0 \\
b \\
0^{\circ} \\
0\end{array}$ & 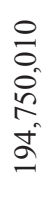 & 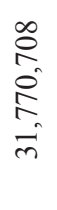 & 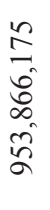 & $\begin{array}{l}a \\
\infty \\
\dot{N} \\
\tilde{n} \\
\hat{\infty} \\
0\end{array}$ \\
\hline 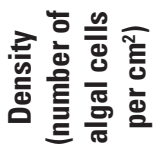 & 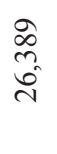 & $\begin{array}{l}\tilde{n} \\
\tilde{n} \\
\varrho\end{array}$ & $\begin{array}{l}n \\
\tilde{n} \\
0 \\
0\end{array}$ & 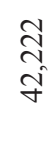 & $\begin{array}{l}0 \\
n \\
n \\
n \\
0\end{array}$ & 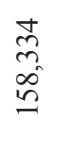 & $\begin{array}{c}\hat{ल} \\
\hat{\sigma}\end{array}$ & $\begin{array}{l}8 \\
\text { d } \\
\stackrel{+}{N}\end{array}$ & $\begin{array}{l}\hat{q} \\
\text { d } \\
\text { do }\end{array}$ & $\begin{array}{l}\Xi \\
\vec{\Xi}\end{array}$ & $\begin{array}{l}\infty \\
\tilde{\sigma} \\
\tilde{f}\end{array}$ & & $\frac{n}{a}$ & $\begin{array}{l}\mathbb{N} \\
\hat{O} \\
\text { d }\end{array}$ & \begin{tabular}{l}
8 \\
\multirow{2}{*}{} \\
if
\end{tabular} & $\frac{\hat{n}}{a}$ & $\frac{n}{a}$ & $\begin{array}{l}\bar{a} \\
\text { हे }\end{array}$ & $\frac{n}{a}$ & $\begin{array}{l}\text { हे } \\
\text { हैं } \\
\text { - }\end{array}$ & $\begin{array}{l}\hat{n} \\
\tilde{a}\end{array}$ \\
\hline $\begin{array}{l}E \\
E \\
\bar{E} \\
\bar{\Xi}\end{array}$ & in & $\sim$ & $\sim$ & $\infty$ & ㄱ. & లి & $\simeq$ & $m$ & - & $\nabla$ & - & & $\sim$ & \pm & $\stackrel{\circ}{\circ}$ & $N$ & $N$ & $\stackrel{\infty}{m}$ & $\sim$ & $\ddot{n}$ & N \\
\hline 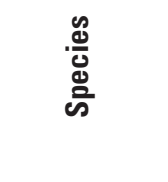 & 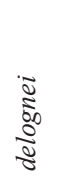 & $\begin{array}{l}5 \\
\overline{5} \\
5 \\
5 \\
5\end{array}$ & 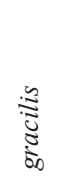 & 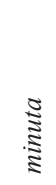 & ミ & 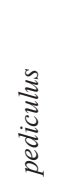 & $\frac{\overline{8}}{\frac{8}{3}}$ & 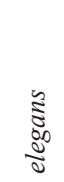 & $\dot{m}$ & 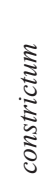 & $\dot{\theta}$ & 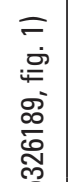 & 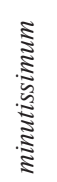 & 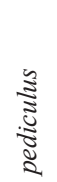 & $\frac{\overline{3}}{3}$ & $\begin{array}{l}\mathbf{\Xi} \\
\mathbb{Z} \\
\mathbb{Z}\end{array}$ & 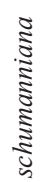 & 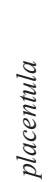 & 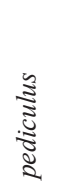 & 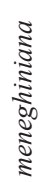 & $\frac{\mathscr{z}}{\mathscr{\sigma}}$ \\
\hline 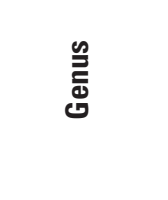 & 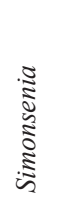 & : & : & : & 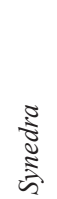 & 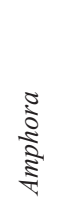 & है & 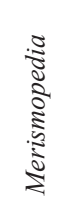 & 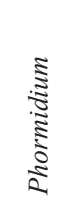 & 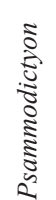 & 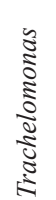 & 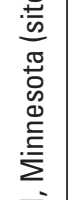 & 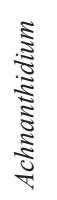 & $\frac{5}{5}$ & $\frac{\pi}{\frac{0}{2}}$ & $\frac{\tilde{\Xi}}{\tilde{\Xi}}$ & $\frac{\tilde{\Xi}}{\tilde{\Xi}}$ & $\begin{array}{l}\tilde{\Xi} \\
\bar{\Xi} \\
\tilde{\Xi}\end{array}$ & $\begin{array}{l}\tilde{\Xi} \\
\tilde{\Xi} \\
\tilde{\Xi} \\
0\end{array}$ & 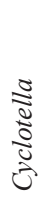 & 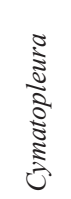 \\
\hline 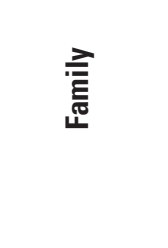 & 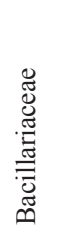 & 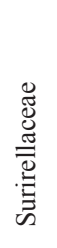 & 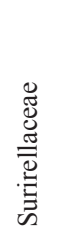 & 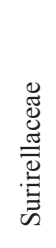 & 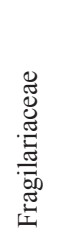 & 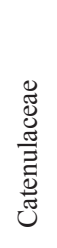 & 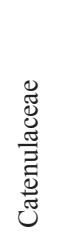 & 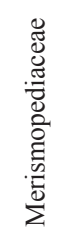 & 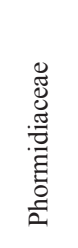 & 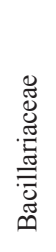 & 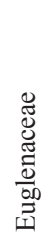 & 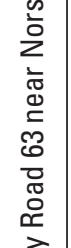 & 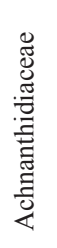 & 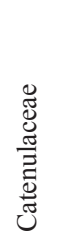 & 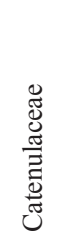 & 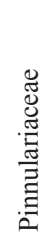 & 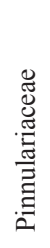 & 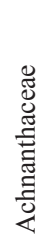 & 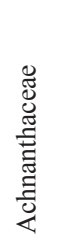 & 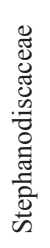 & 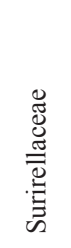 \\
\hline 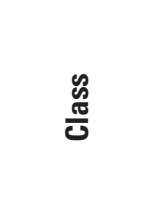 & 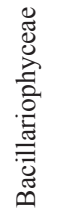 & 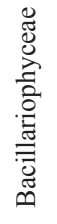 & 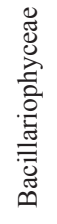 & 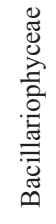 & 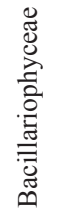 & 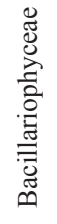 & 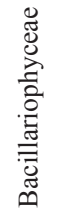 & 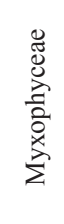 & 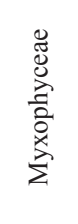 & 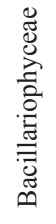 & 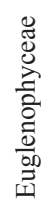 & 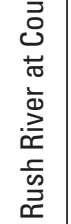 & 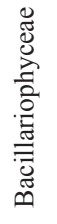 & 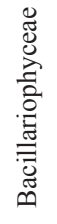 & 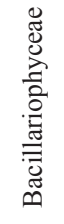 & 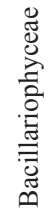 & 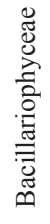 & 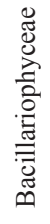 & 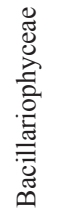 & 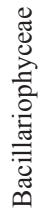 & 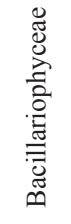 \\
\hline 衰 & 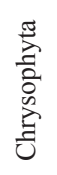 & 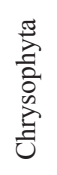 & 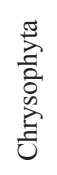 & 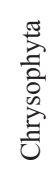 & 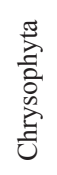 & 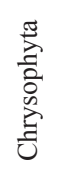 & 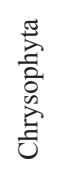 & 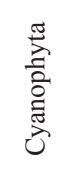 & 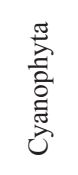 & 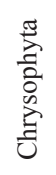 & 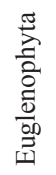 & 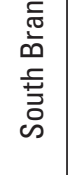 & 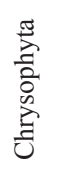 & 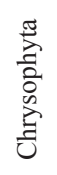 & 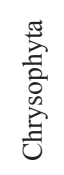 & 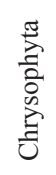 & 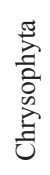 & 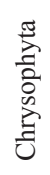 & 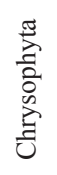 & 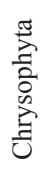 & 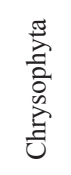 \\
\hline 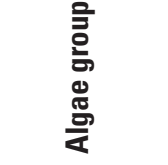 & 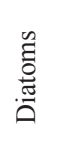 & 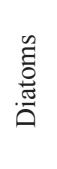 & 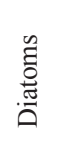 & 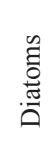 & 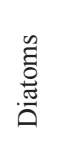 & 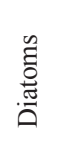 & 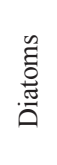 & 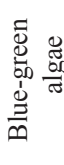 & 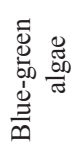 & 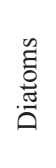 & $\begin{array}{l}\frac{y}{0} \\
\overline{0} \\
\overline{0} \\
\frac{0}{00} \\
\vec{I} \\
\overline{1}\end{array}$ & & 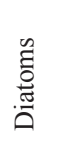 & 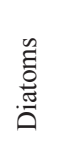 & 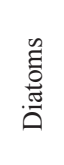 & 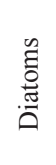 & 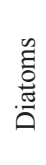 & 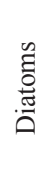 & 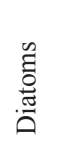 & 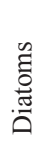 & 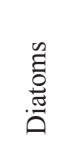 \\
\hline 号 & 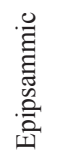 & 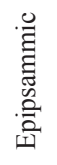 & 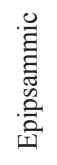 & 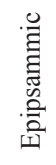 & 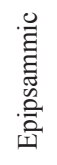 & 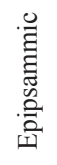 & 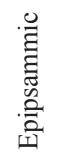 & 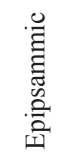 & 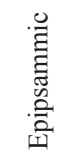 & 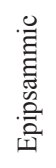 & 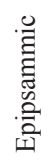 & & 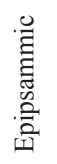 & 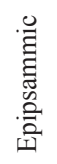 & 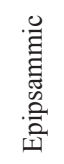 & 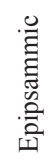 & 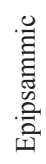 & 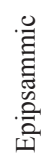 & 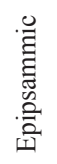 & 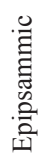 & 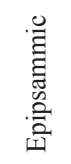 \\
\hline 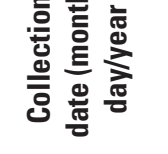 & 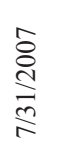 & 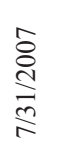 & $\begin{array}{l}\hat{\mathrm{a}} \\
\stackrel{\mathrm{m}}{\mathrm{n}}\end{array}$ & 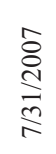 & 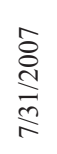 & 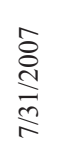 & 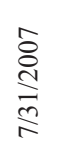 & $\frac{\stackrel{i}{\mathbf{i}}}{\stackrel{m}{n}}$ & 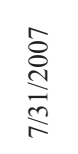 & 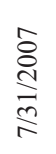 & $\frac{\stackrel{i}{\grave{1}}}{\stackrel{m}{n}}$ & & 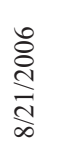 & 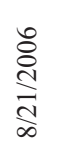 & 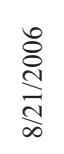 & 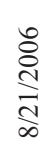 & 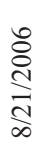 & 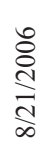 & 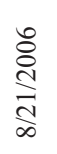 & 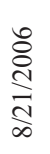 & ¿ัญ \\
\hline
\end{tabular}




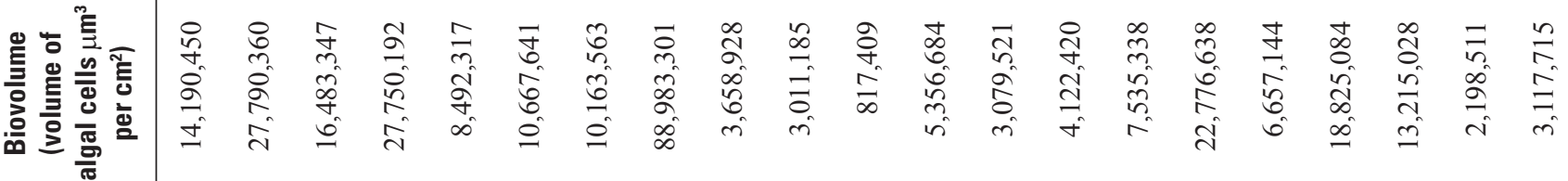

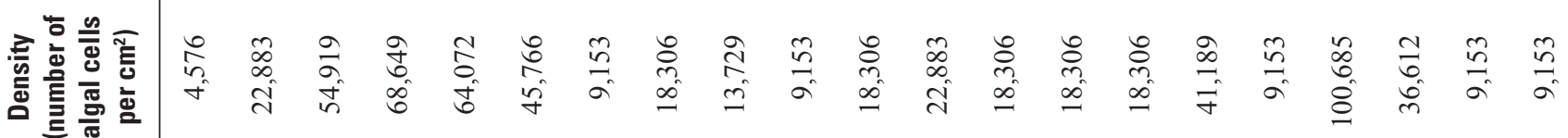

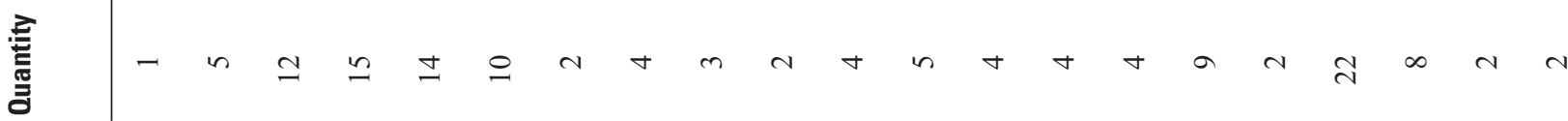

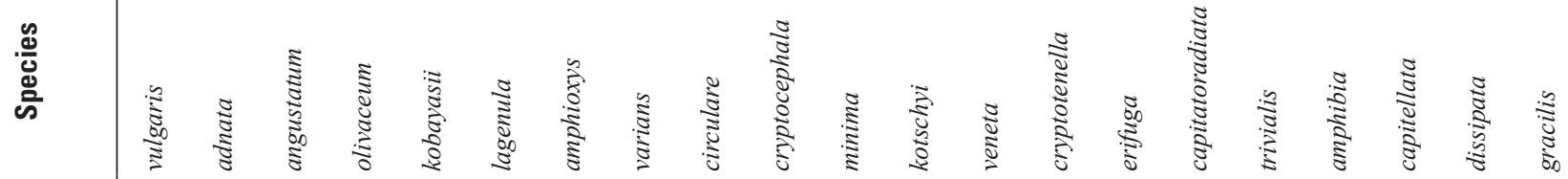

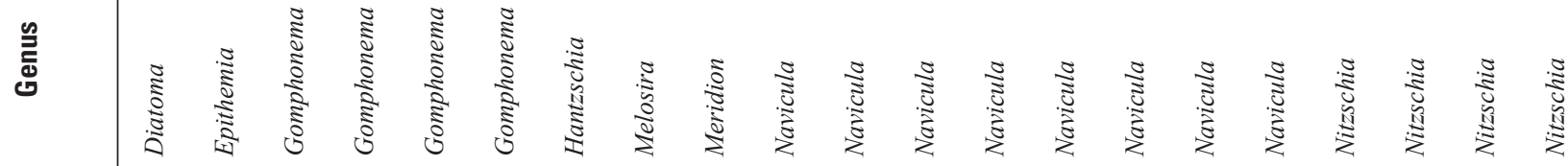

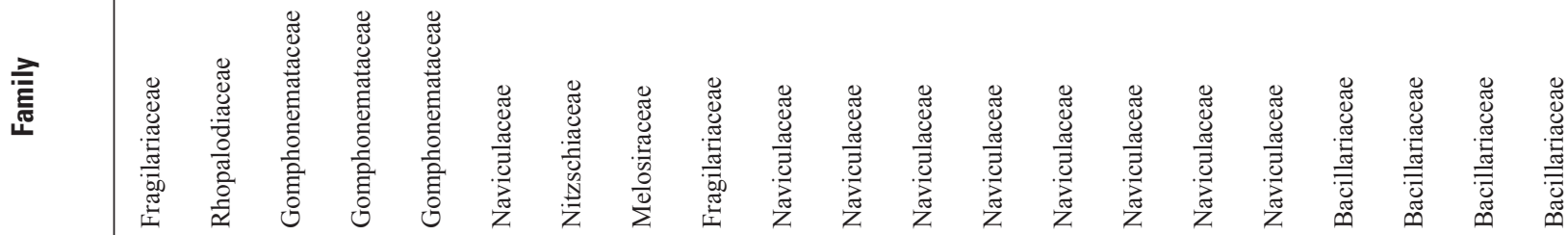

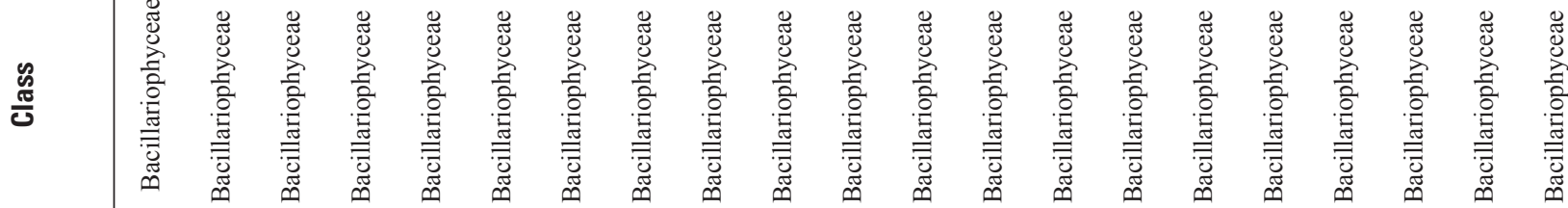

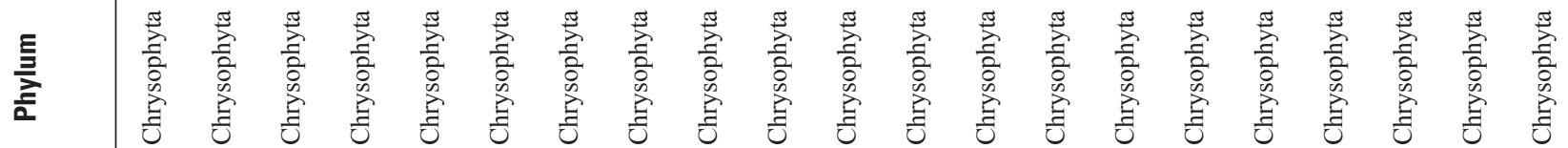

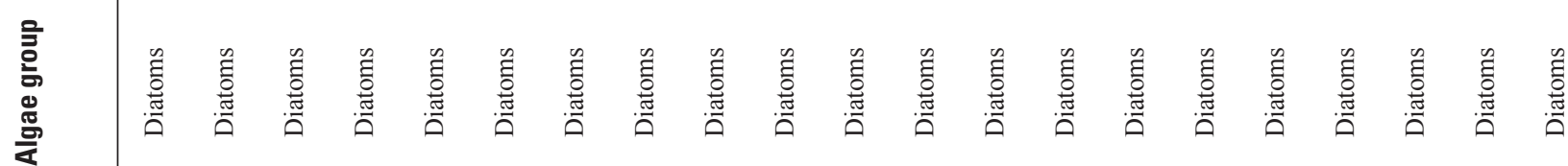

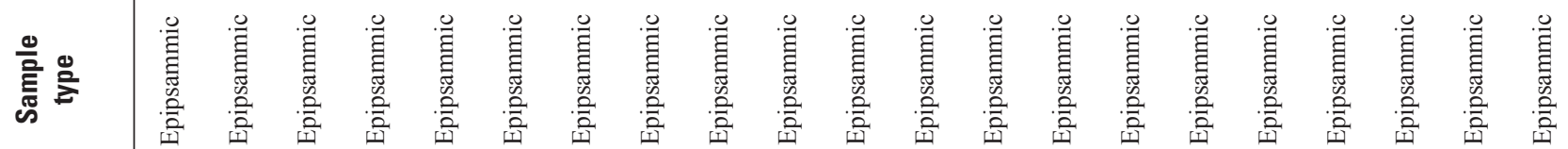

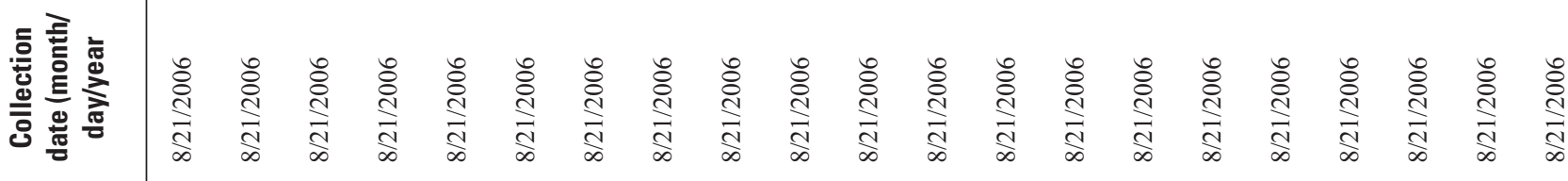




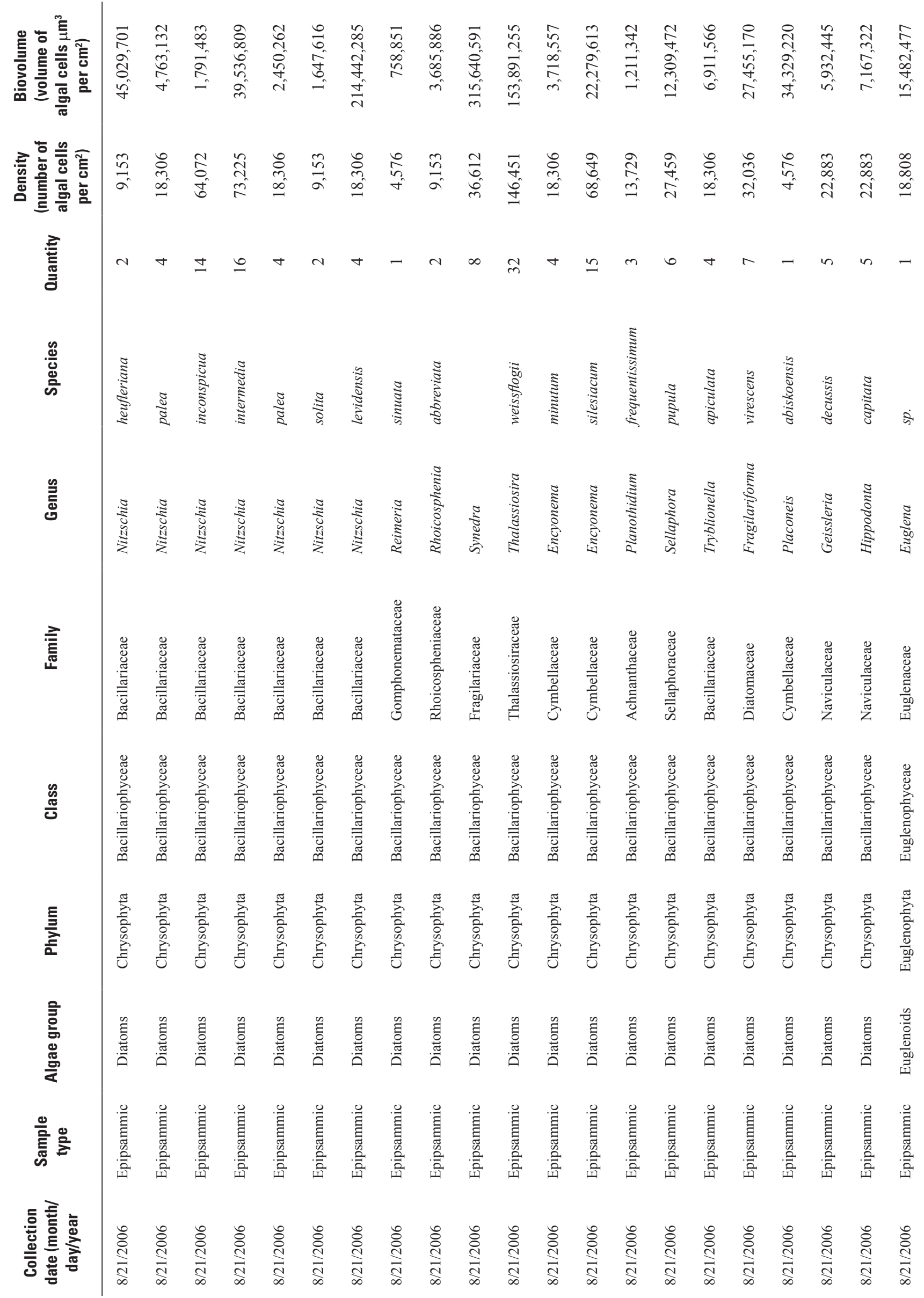




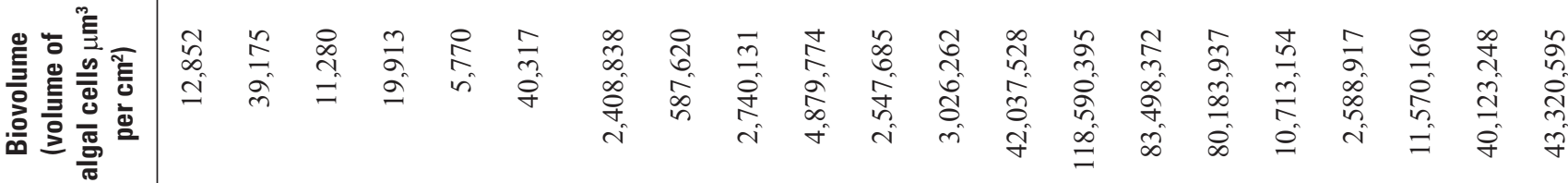

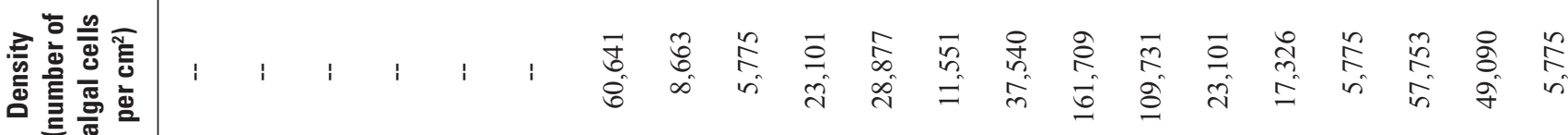

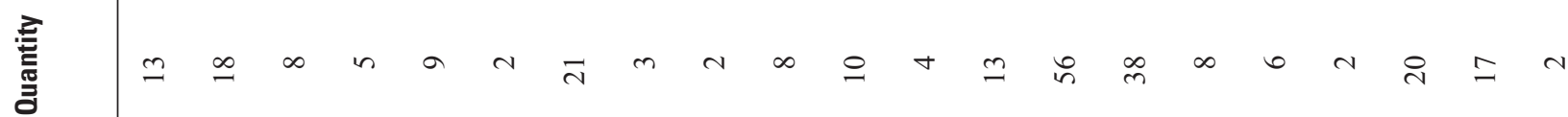

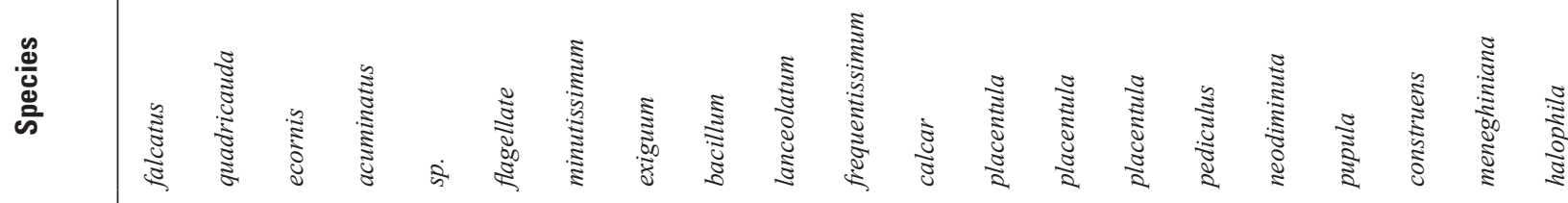

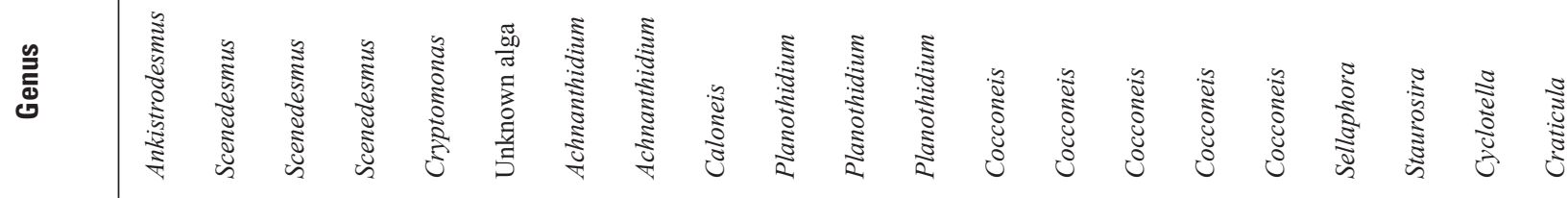

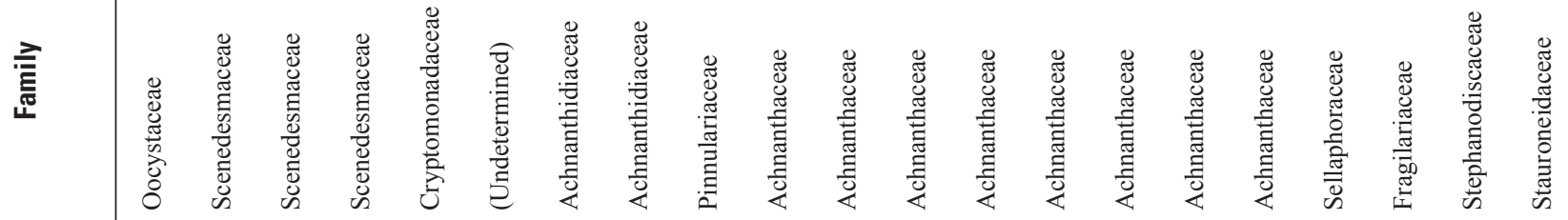

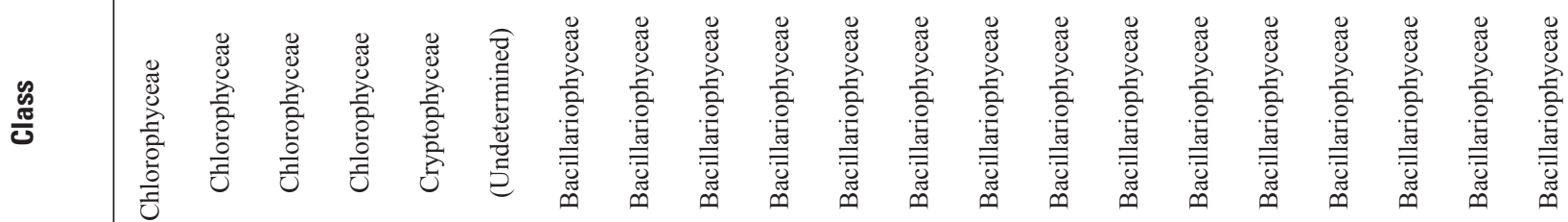

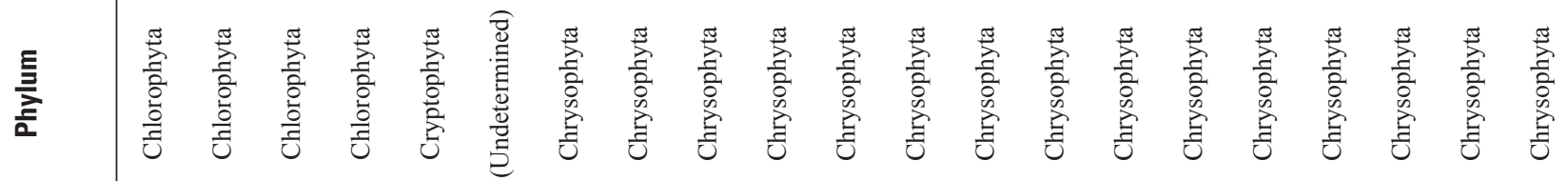

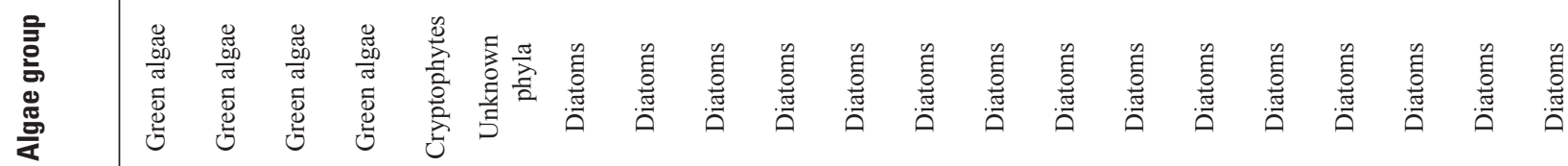

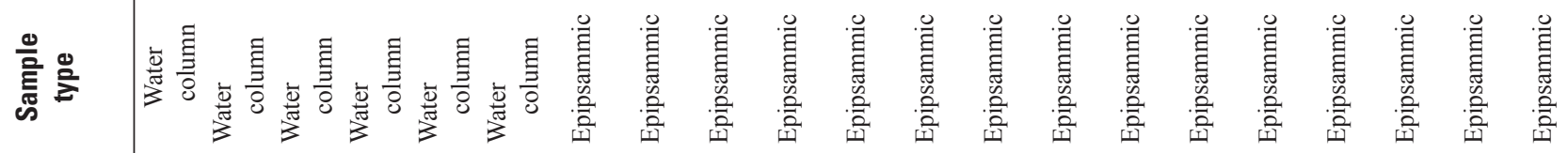

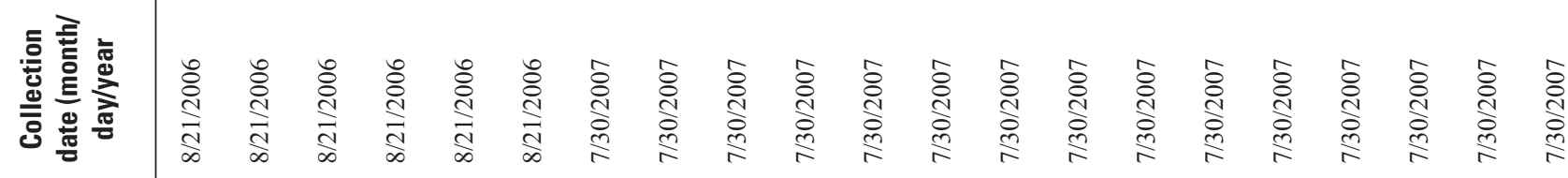




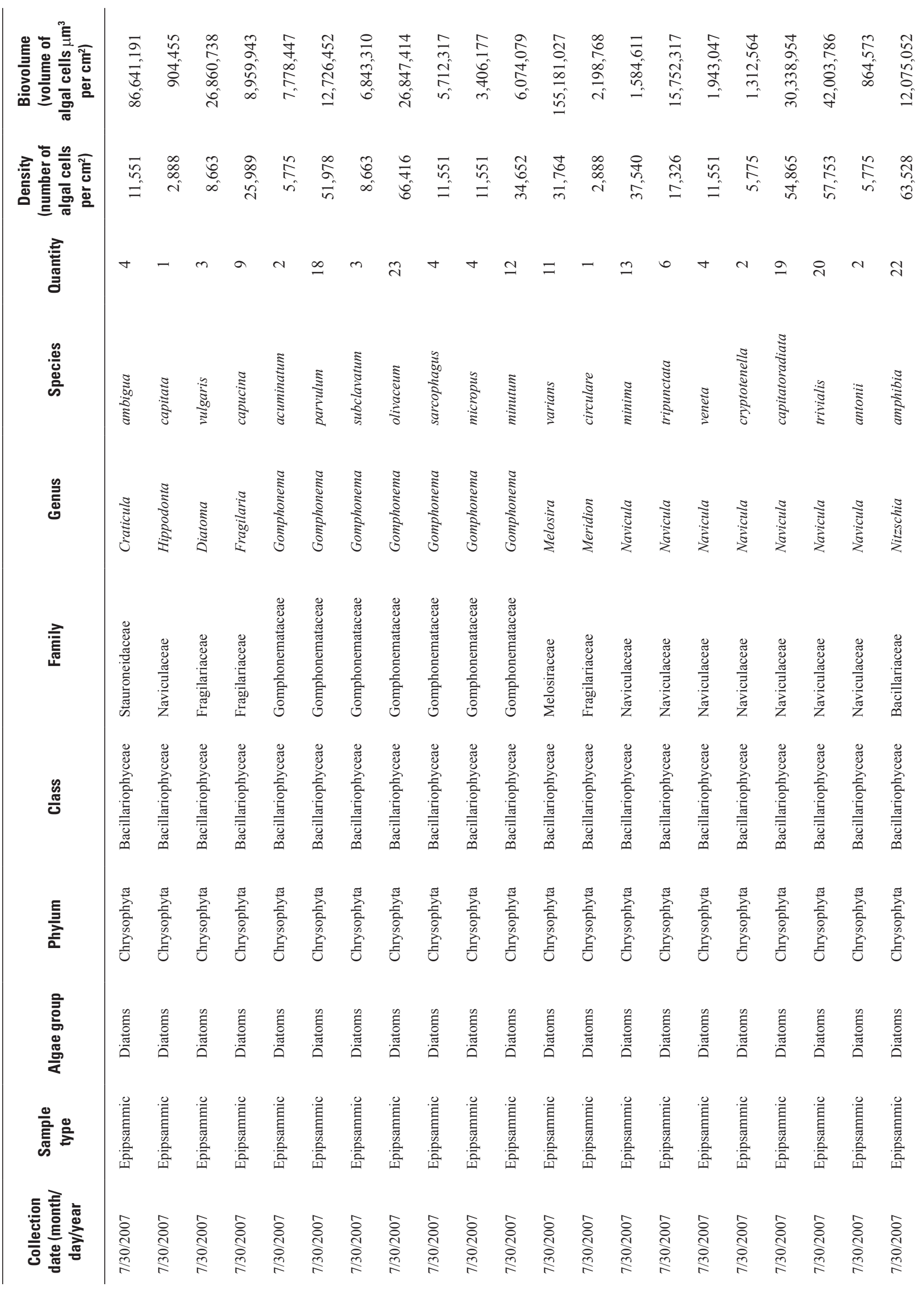




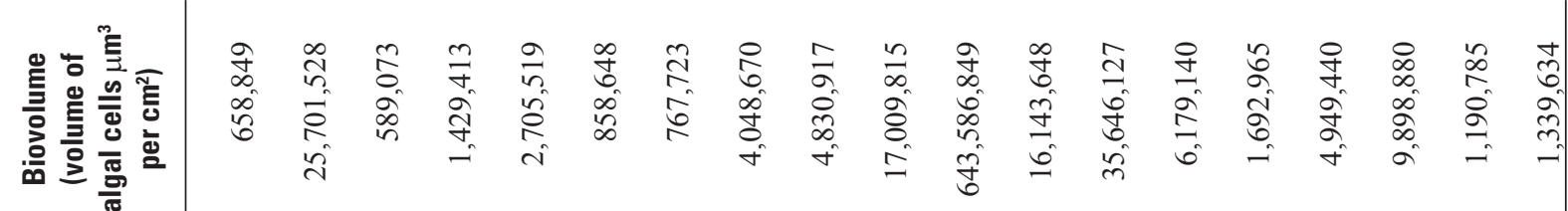

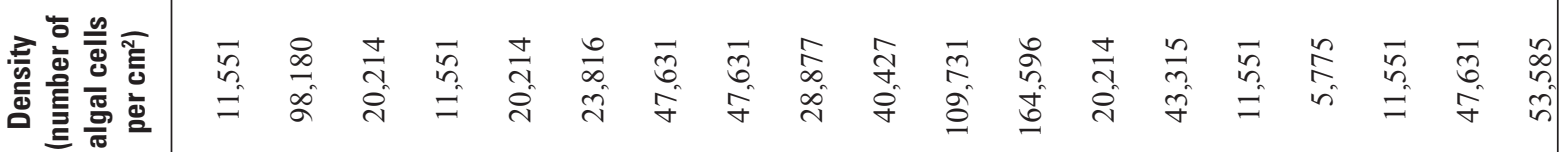

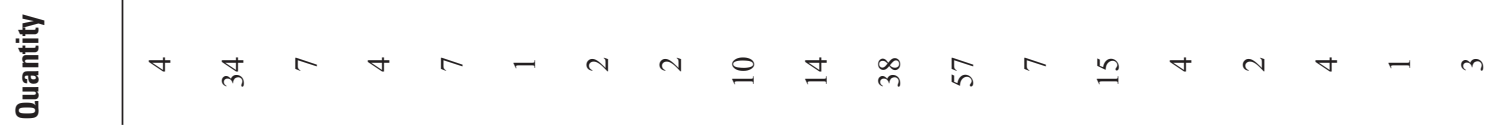

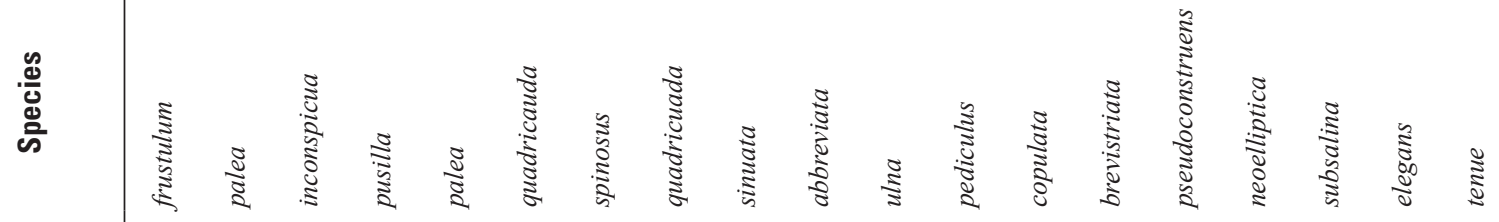

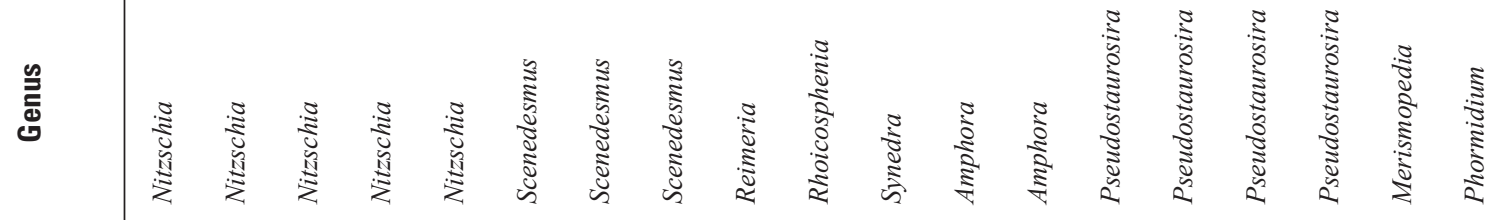

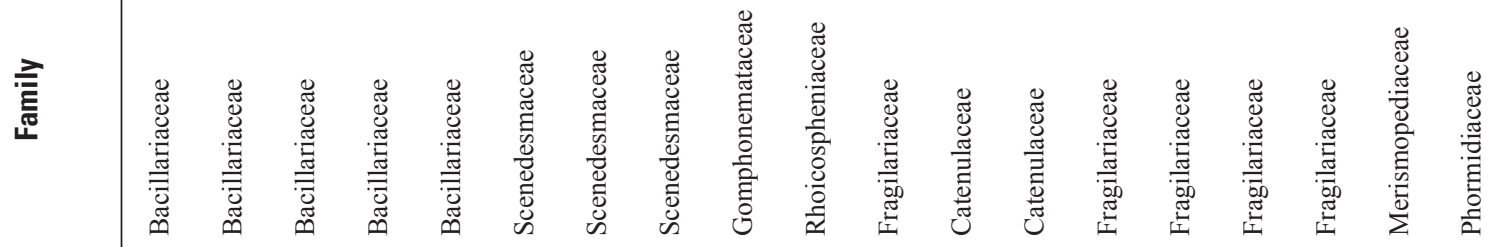

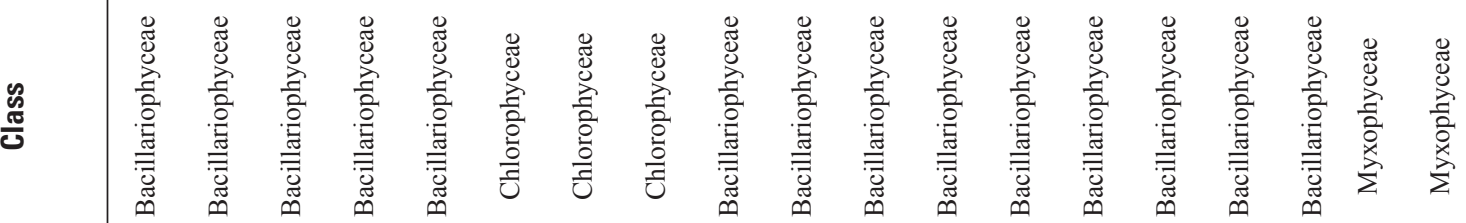

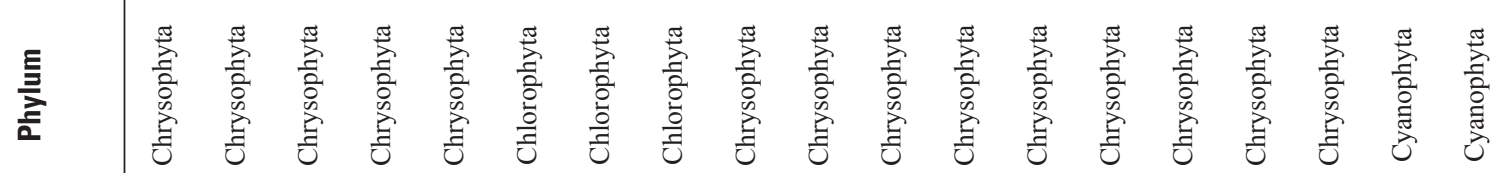

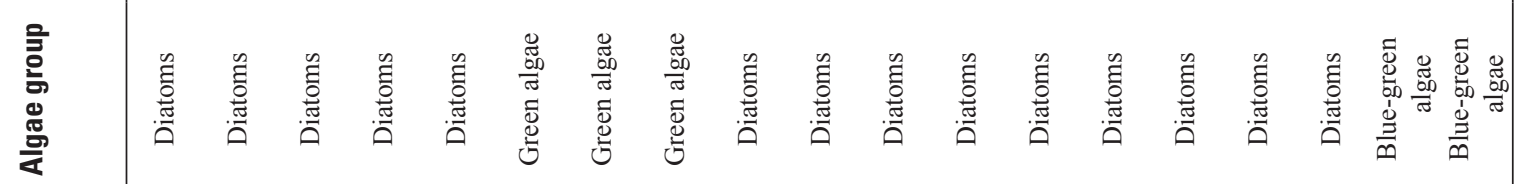

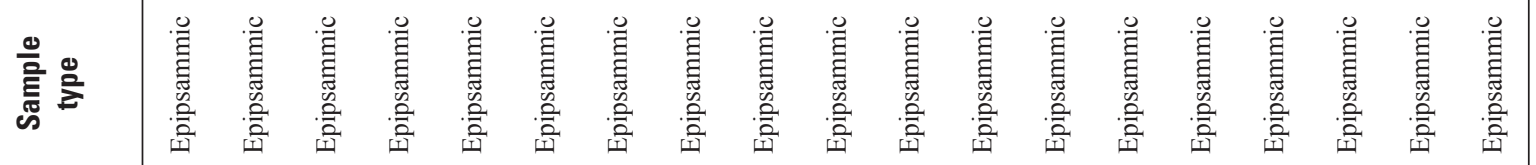

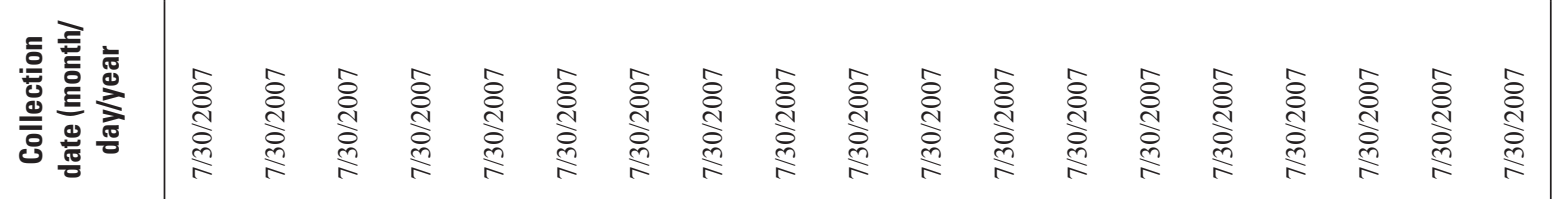


Appendix 2. Invertebrate Species Composition and Abundance for Samples Collected from Chetomba Creek, West Fork Beaver Creek, and South Branch Rush River, August 2006 and July 2007 


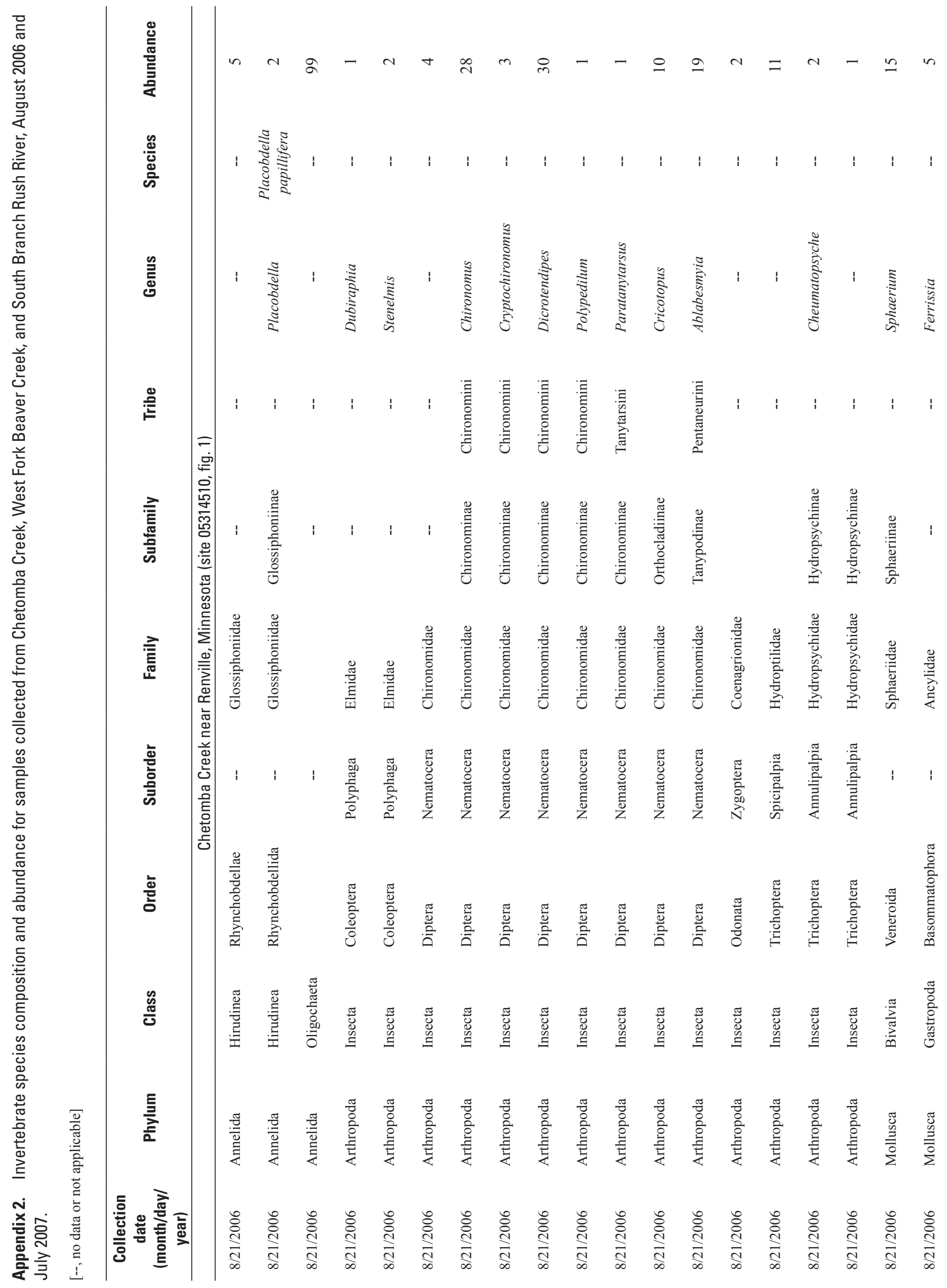




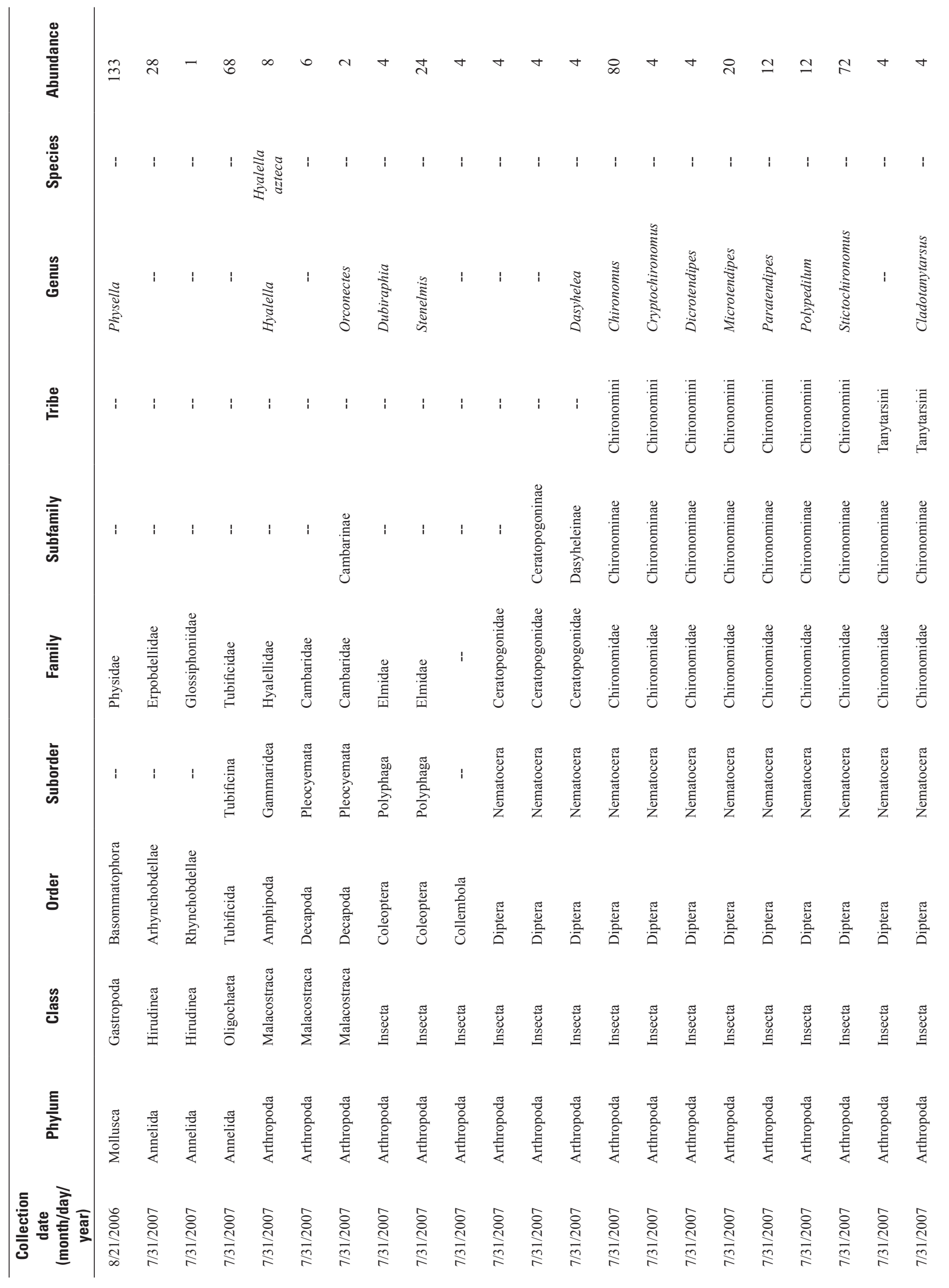




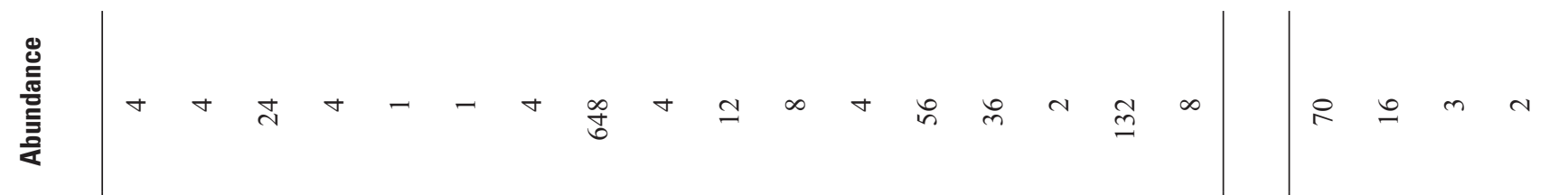

क⿺辶ّ

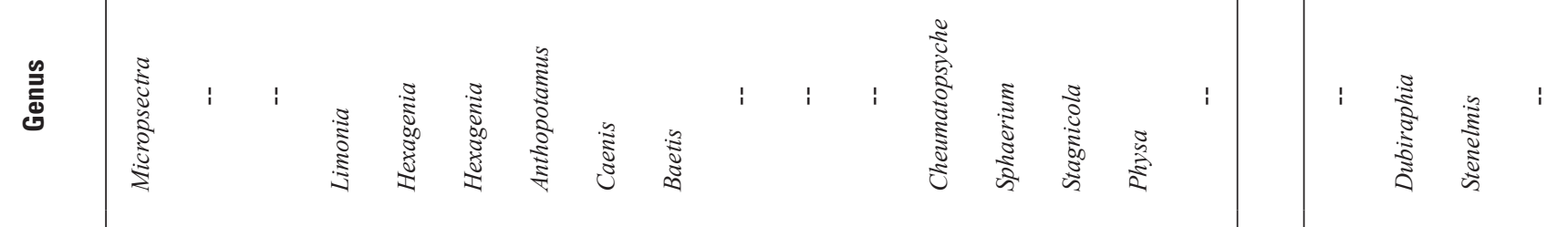

高

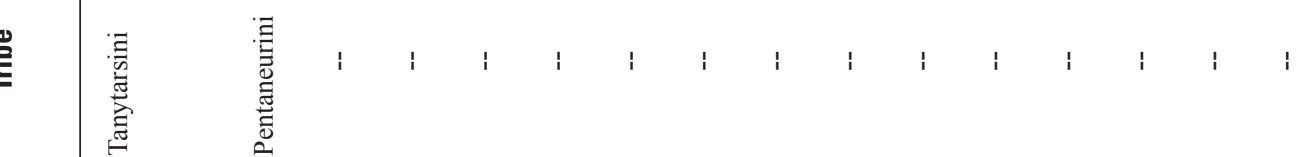

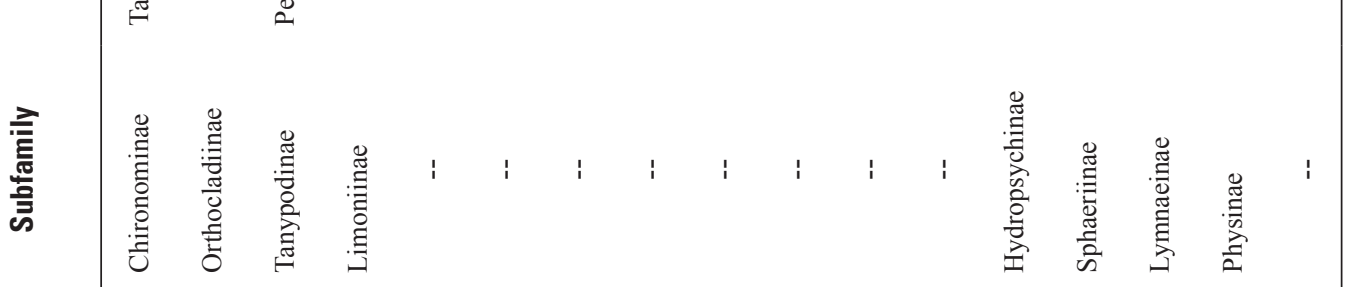

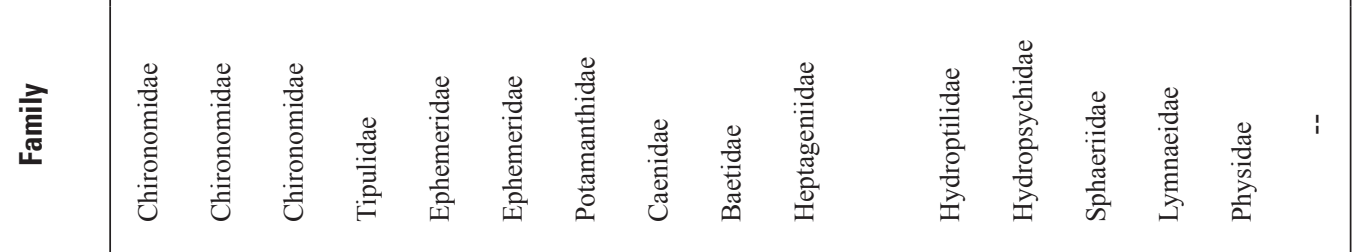

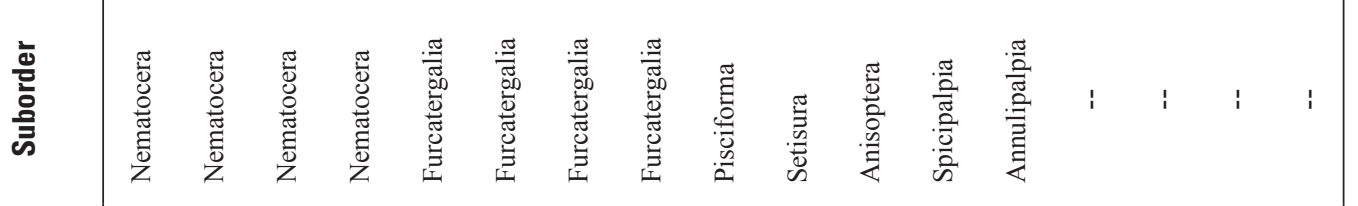

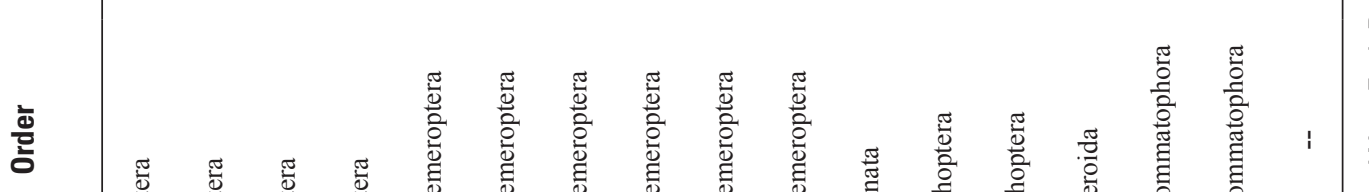

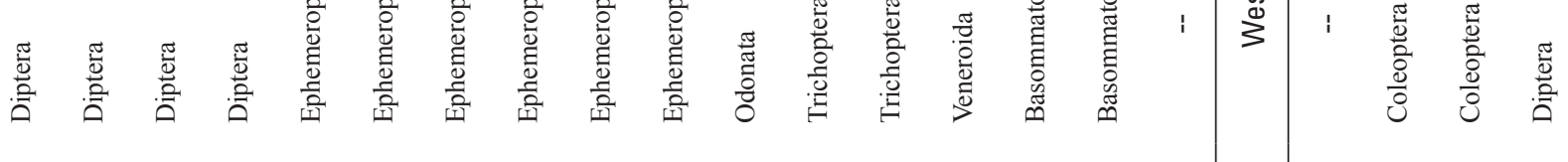

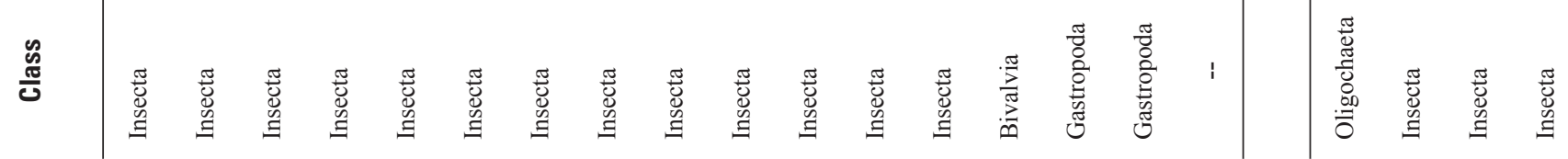

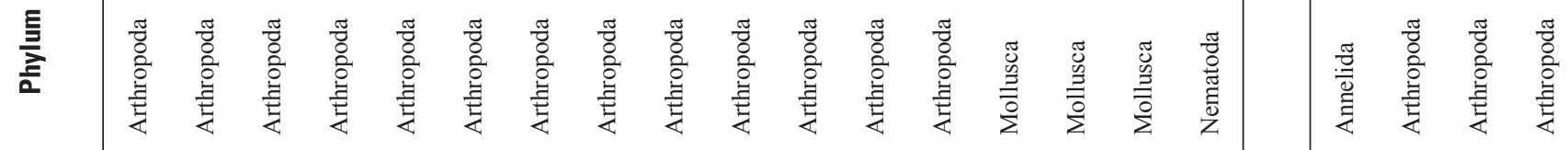

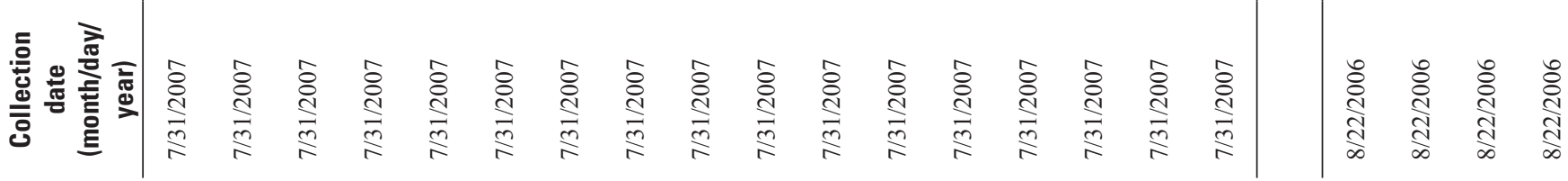




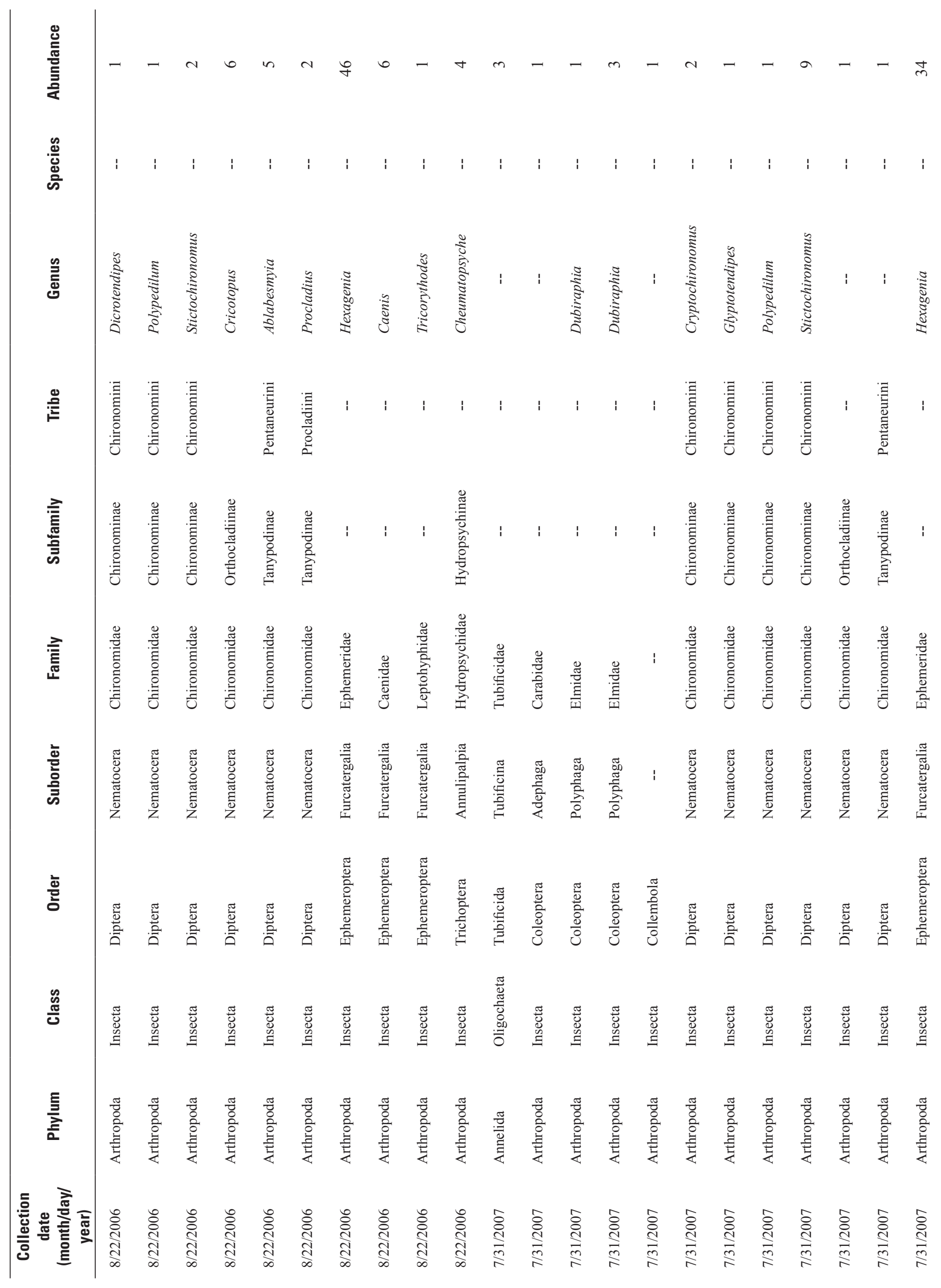




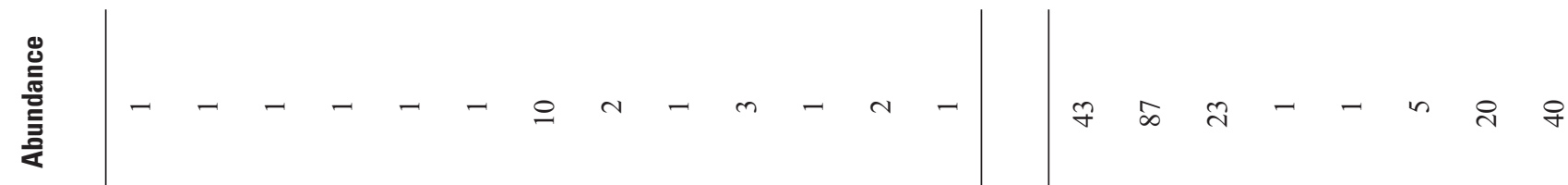

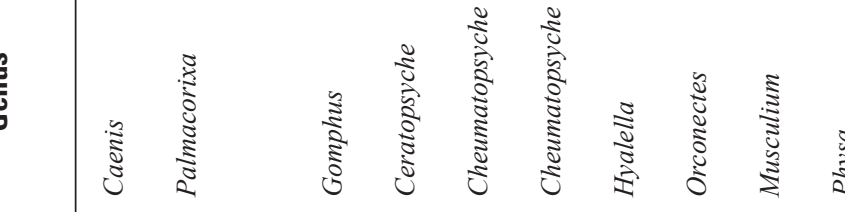

胥芯

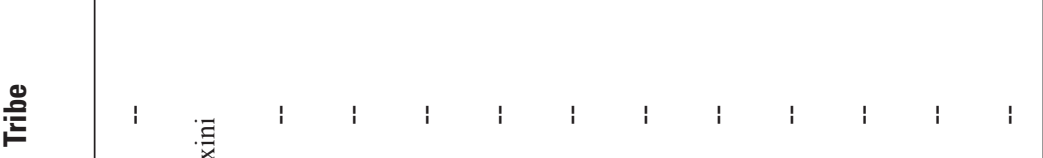

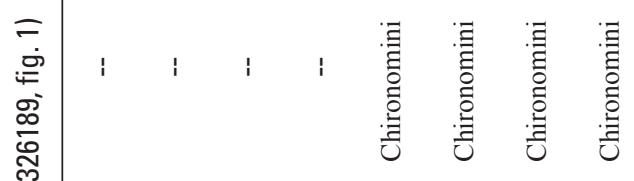

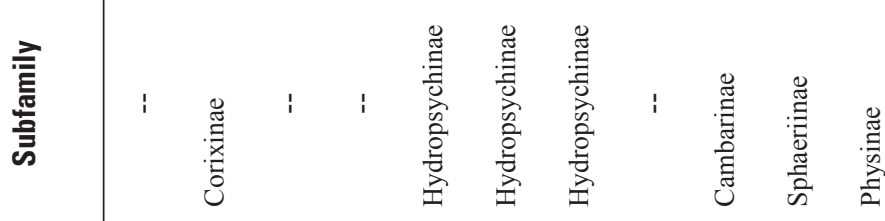

ㄴㅇㅇ

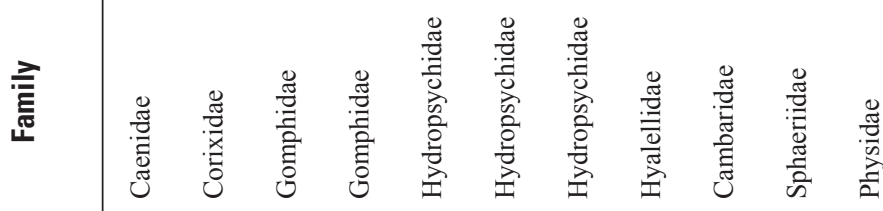

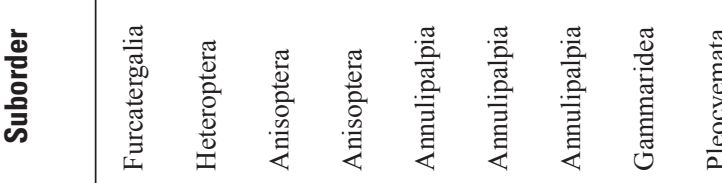

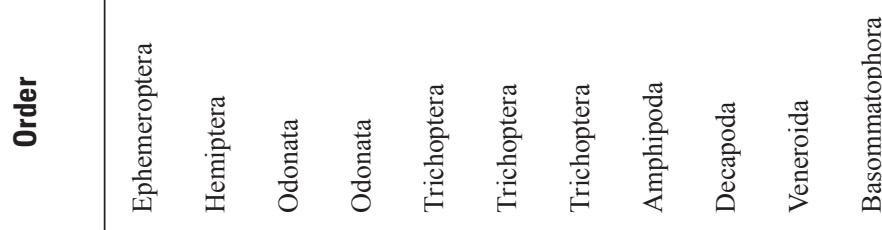

$1 \quad 1 \quad \begin{array}{ccc}2 \\ 2\end{array}$

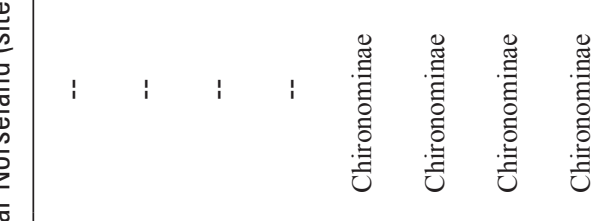

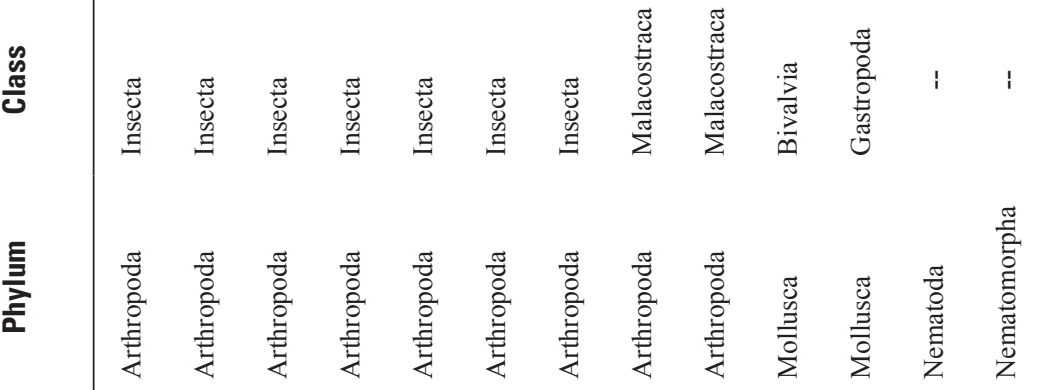

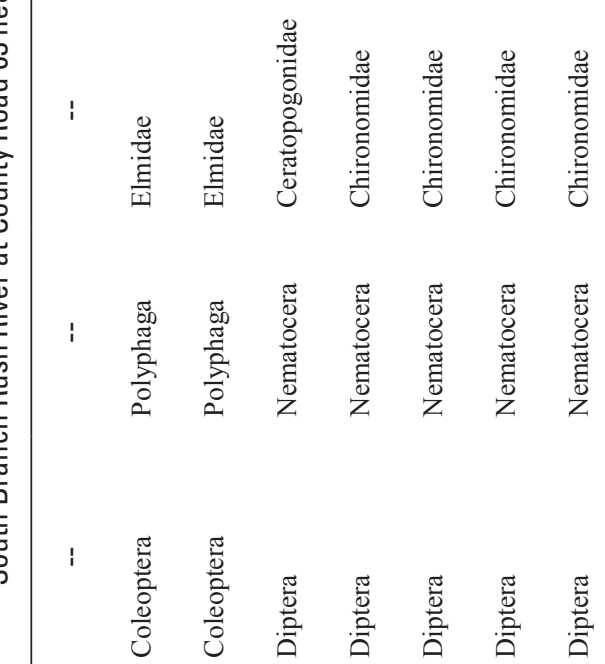

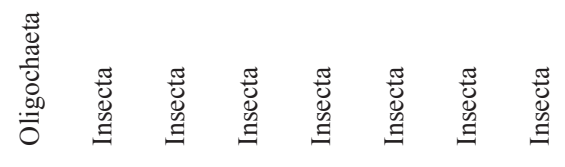

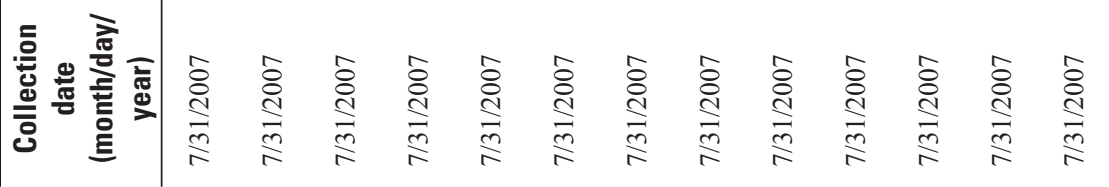

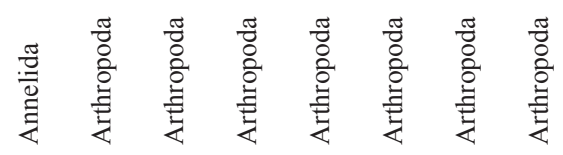

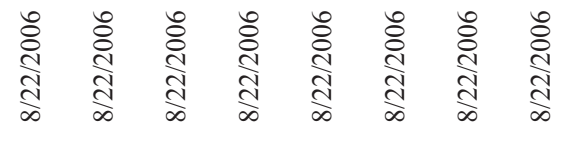




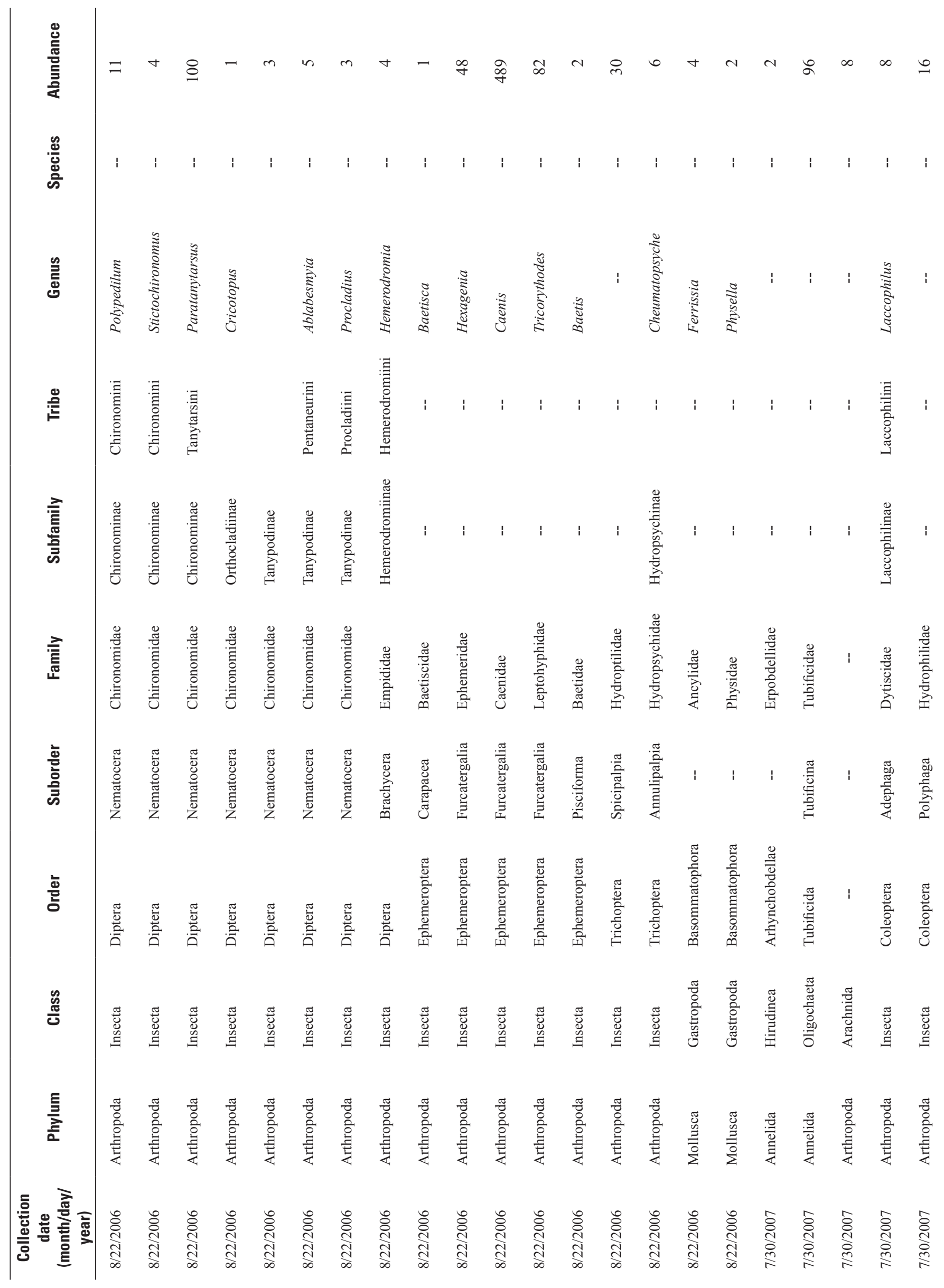




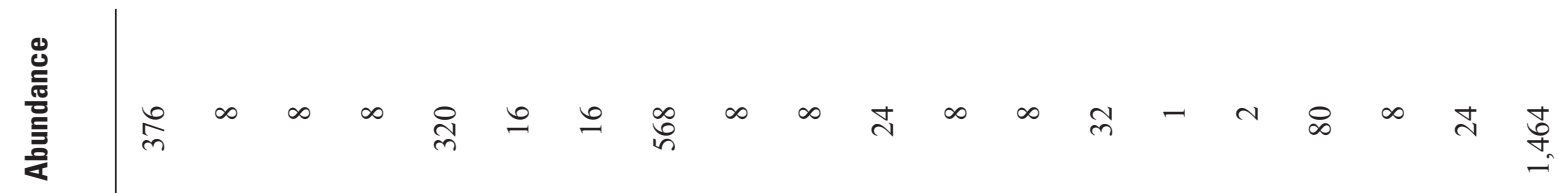

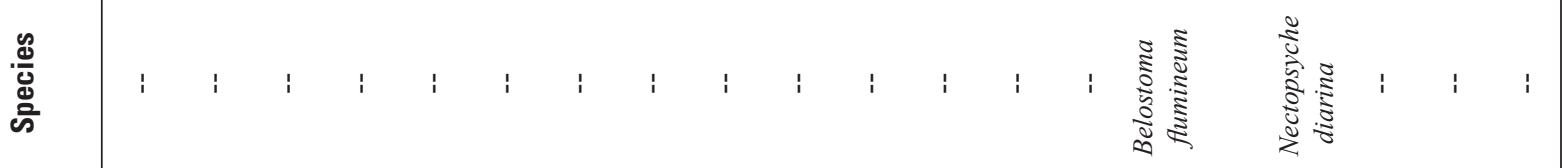

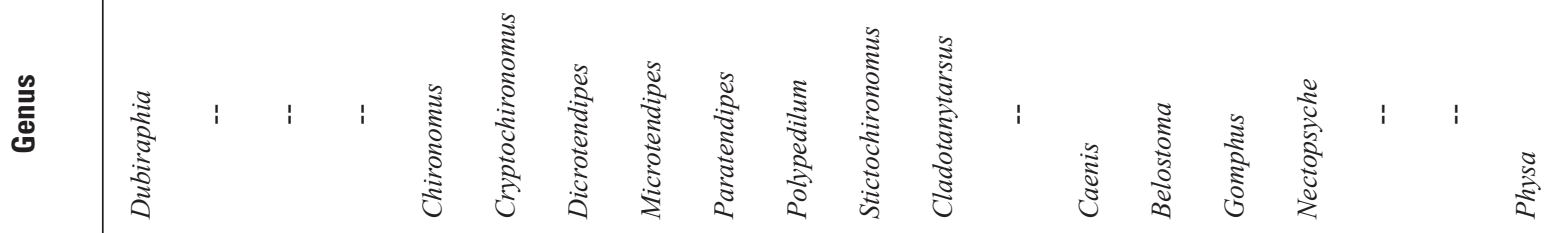

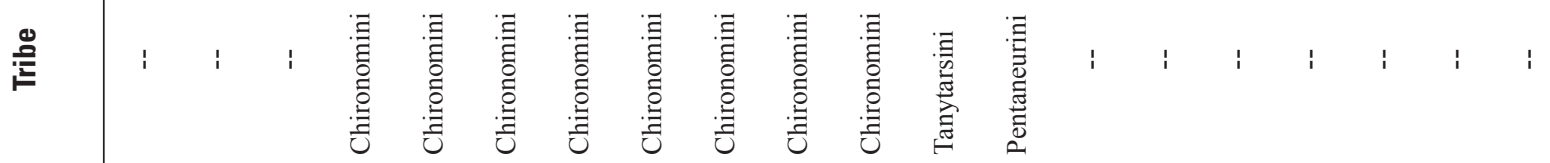

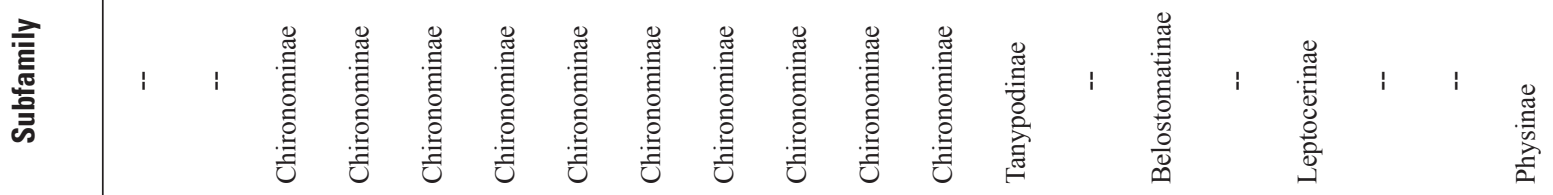

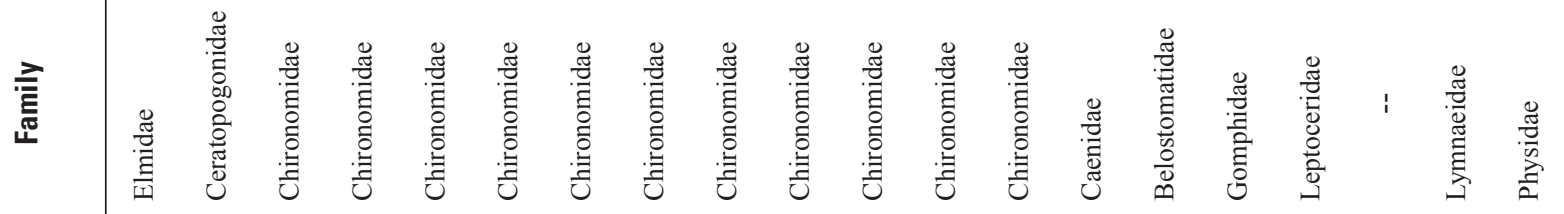

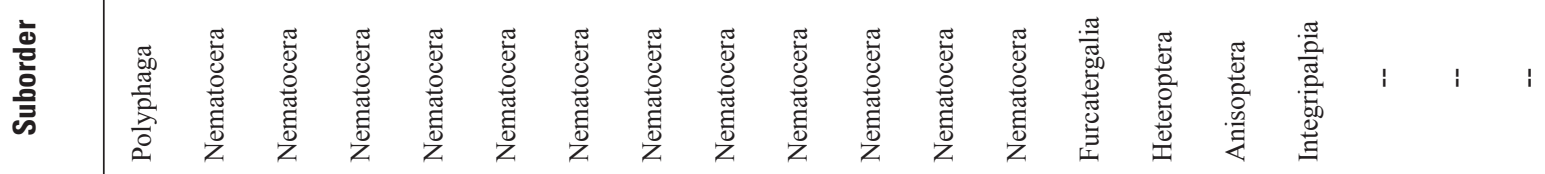

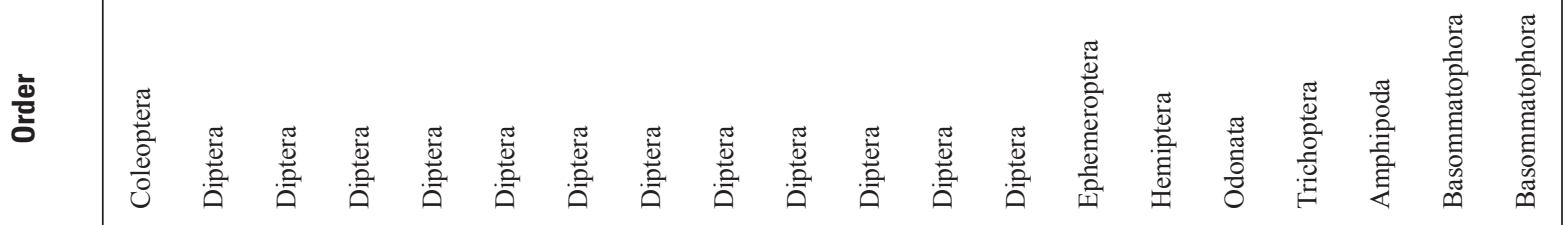

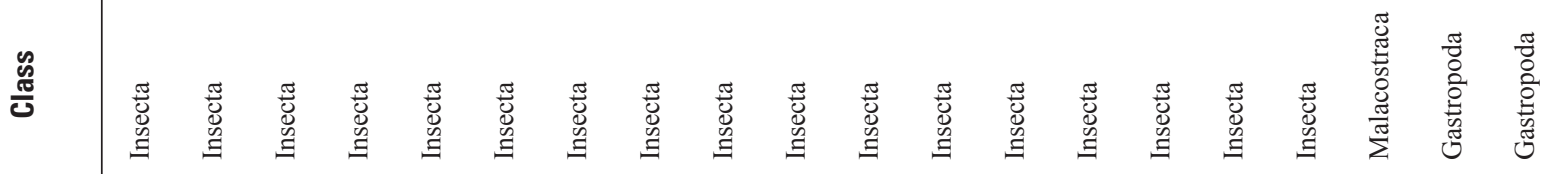

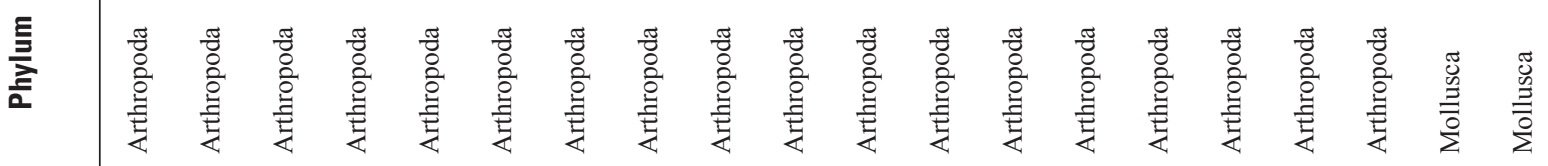

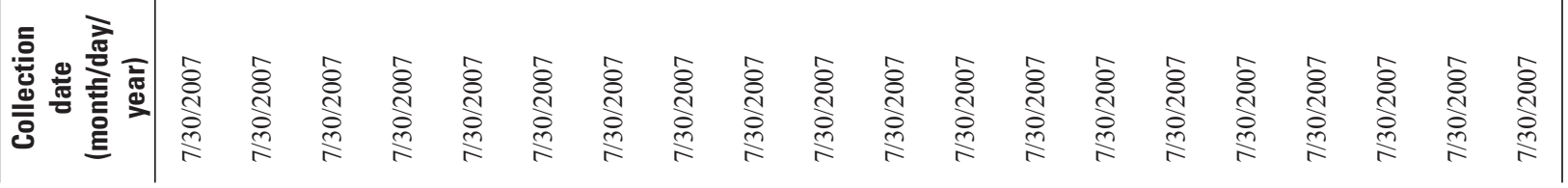


Appendix 3. Fish Species Composition, Weight, and Catch per Unit Effort for Samples Collected from Chetomba Creek, West Fork Beaver Creek, and South Branch Rush River, August 2006 and 2007 


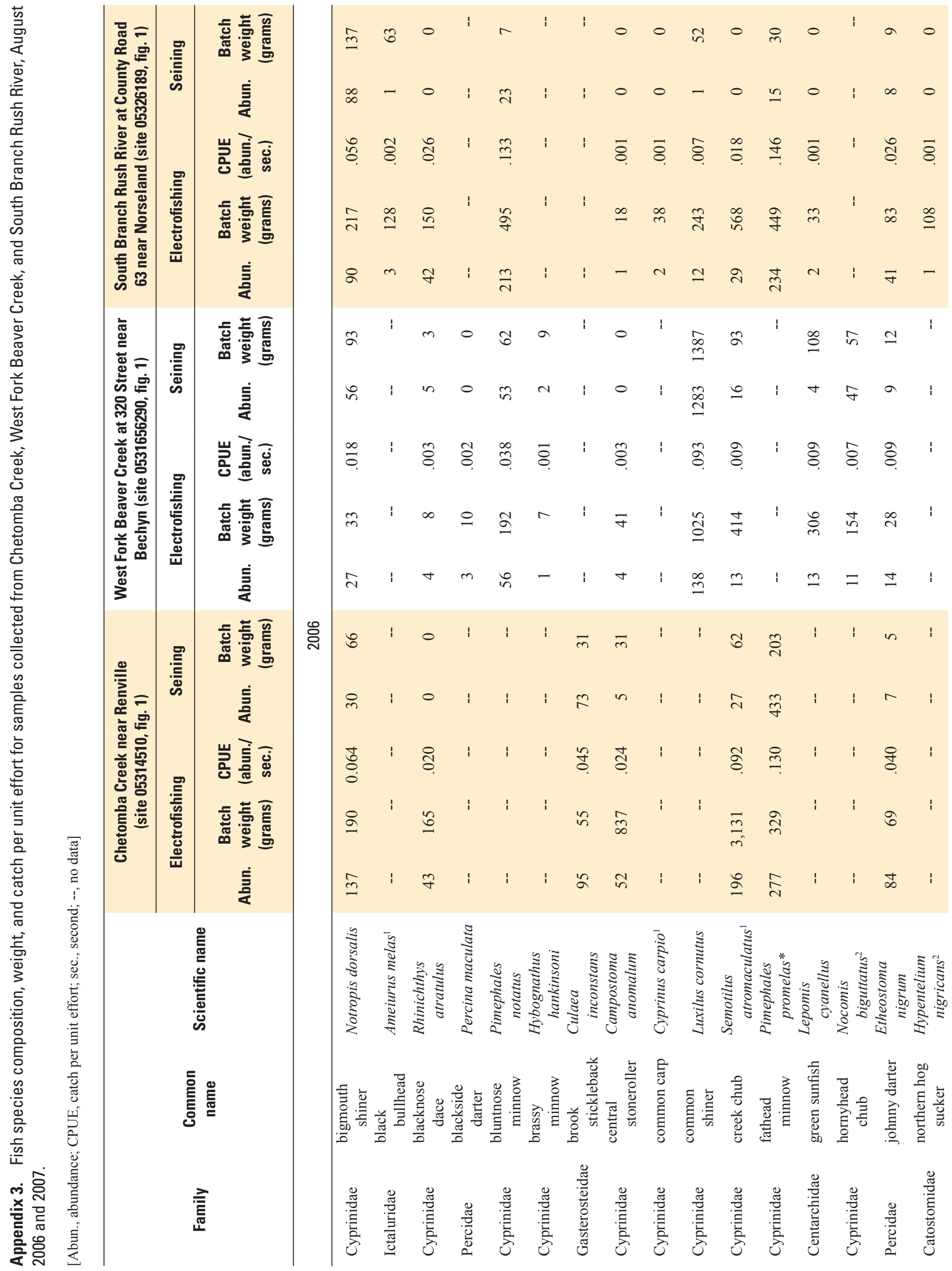




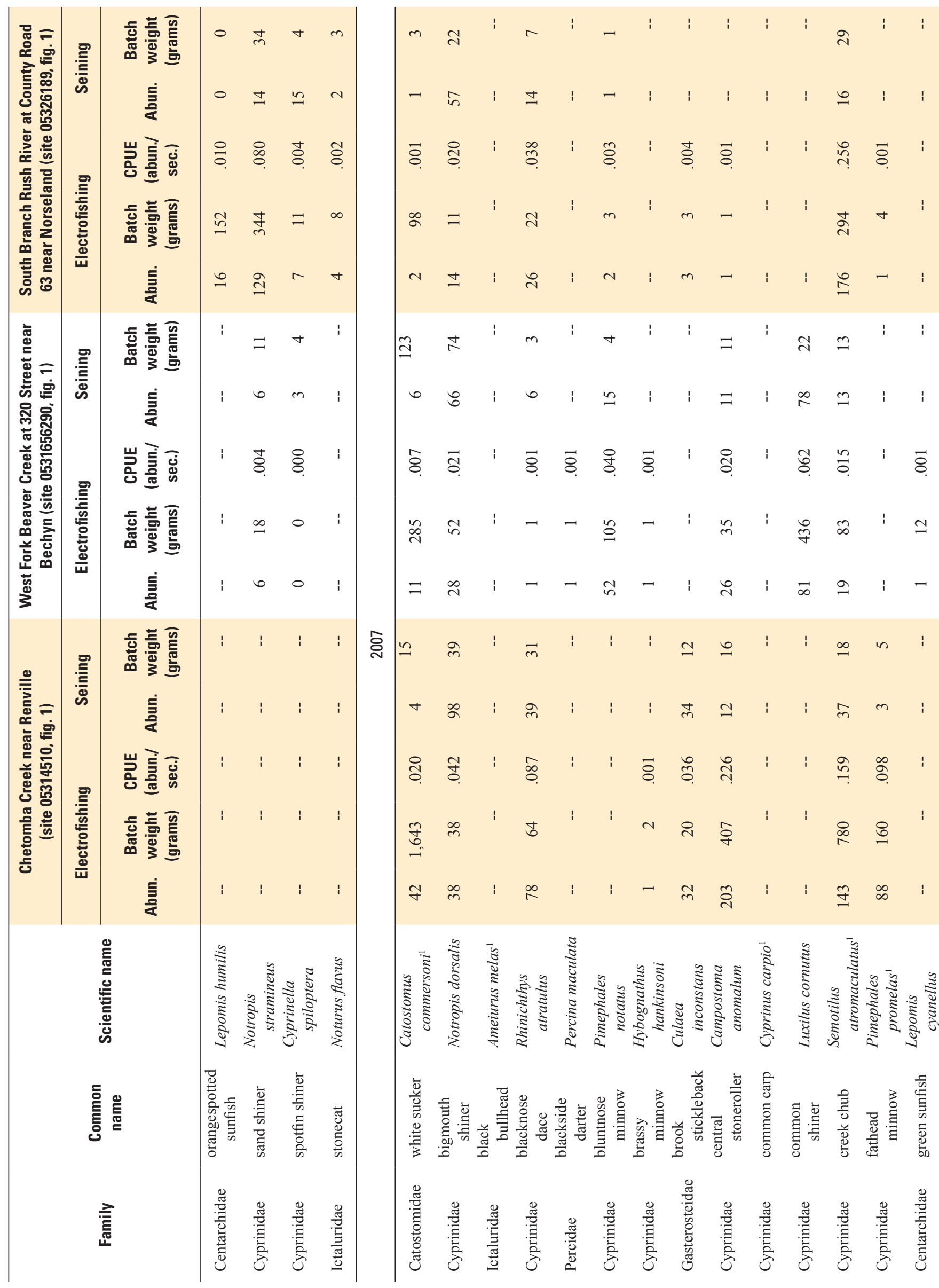


3-4 Water-Quality and Biological Characteristics and Responses to Agricultural Land Retirement, Water Years 2006-08

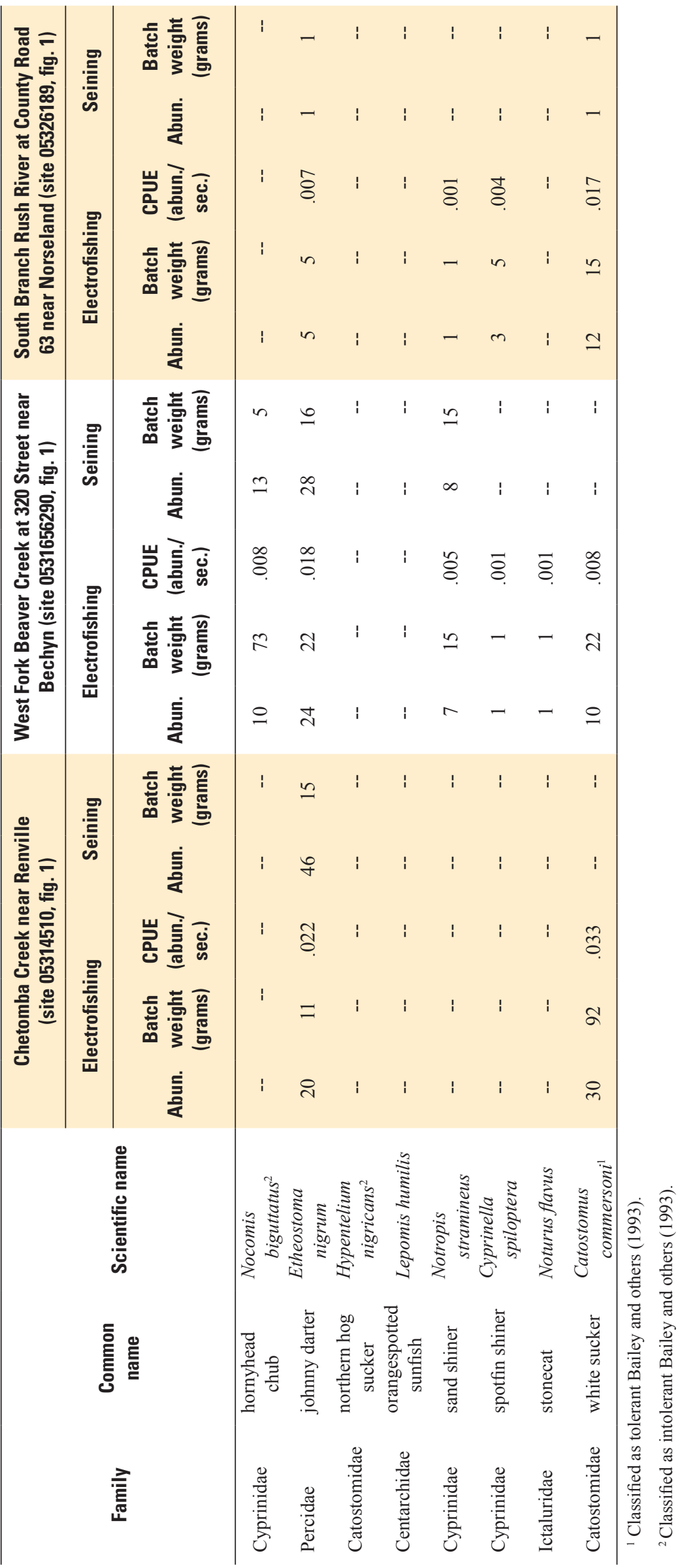




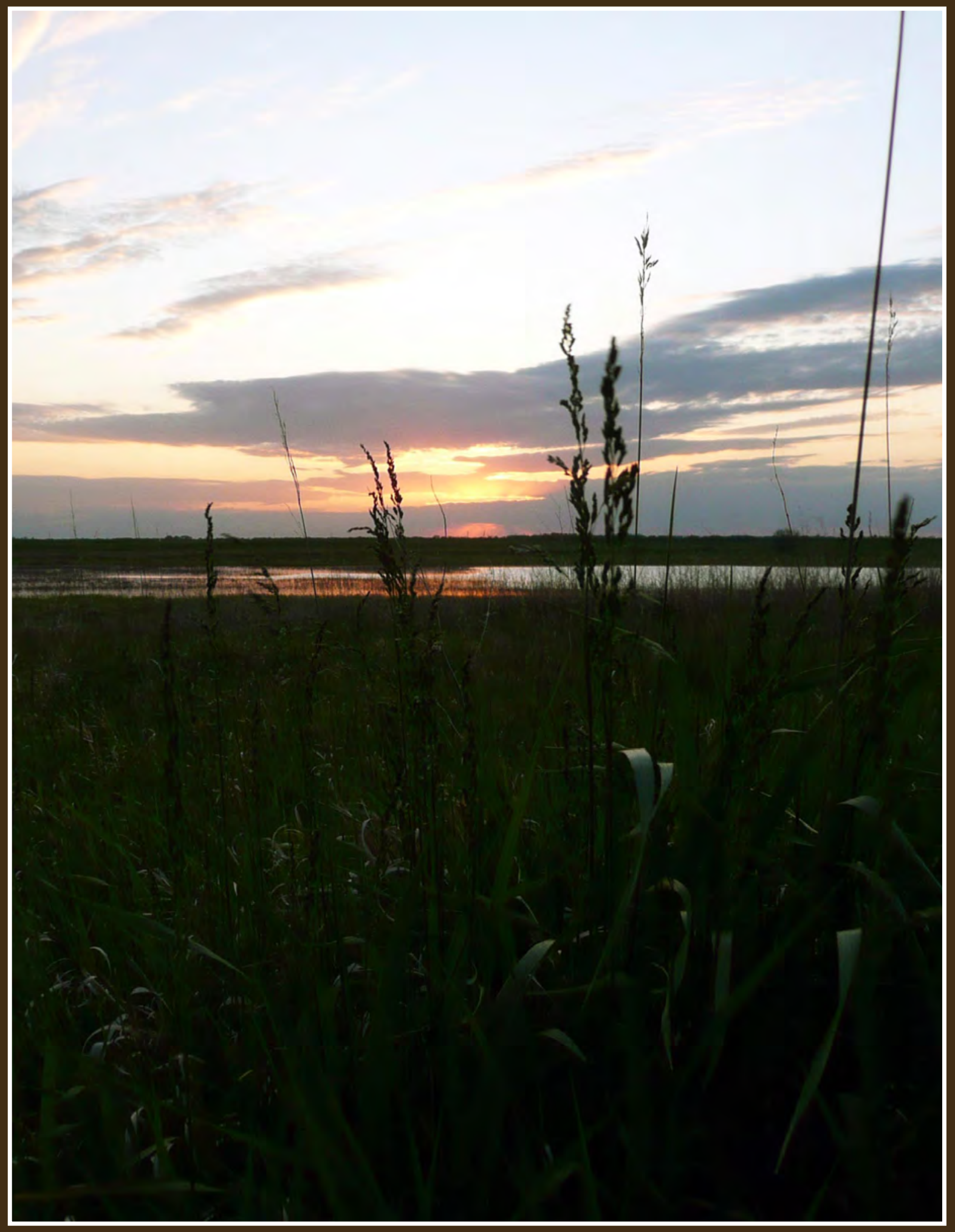


Publishing support provided by

Rolla and Lafayette Publishing Service Centers 

